\title{
WestVirginiaUniversity
}

THE RESEARCH REPOSITORY @ WVU

Graduate Theses, Dissertations, and Problem Reports

2008

\section{Technology use in a middle school in 1997 and 2007}

\author{
Melinda L. Marple \\ West Virginia University
}

Follow this and additional works at: https://researchrepository.wvu.edu/etd

\section{Recommended Citation}

Marple, Melinda L., "Technology use in a middle school in 1997 and 2007" (2008). Graduate Theses, Dissertations, and Problem Reports. 4401.

https://researchrepository.wvu.edu/etd/4401

This Dissertation is protected by copyright and/or related rights. It has been brought to you by the The Research Repository @ WVU with permission from the rights-holder(s). You are free to use this Dissertation in any way that is permitted by the copyright and related rights legislation that applies to your use. For other uses you must obtain permission from the rights-holder(s) directly, unless additional rights are indicated by a Creative Commons license in the record and/ or on the work itself. This Dissertation has been accepted for inclusion in WVU Graduate Theses, Dissertations, and Problem Reports collection by an authorized administrator of The Research Repository @ WVU.

For more information, please contact researchrepository@mail.wvu.edu. 
Technology Use in a Middle School in 1997 and 2007

Melinda L. Marple. M.S.

Dissertation submitted to the College of Human Resources and Education at West Virginia University in partial fulfillment of the requirement for

Doctor of Education

in

Technology Education

Neal Shambaugh, Ph.D, Chair

David McCrory, Ph.D. Jaci Webb-Dempsey, Ph.D.

Carol Markstrom, Ph.D.

Paula Nelson, Ed.D.

Morgantown, West Virginia

2008

Keywords: Technology Integration, Middle School, Computer Anxiety, Technology Integration Readiness, Technology Infrastructure, Impact of Technology 


\author{
ABSTRACT \\ Technology Use in a Middle School in 1997 and 2007 \\ Melinda L. Marple
}

The purpose of this study was to determine if any changes in technology integration and adoption of computer technology had taken place at ABC Middle School from the initial pilot study in 1997 and the follow-up study in 2007. This research looked for changes in the teachers' computer anxieties, attitudes and computer use from the previous study. Research showed that teacher anxiety had an impact on the teachers' willingness to integrate the technology into their curriculum. So it is important to understand the anxiety level in order to assess the willingness-to-integrate level.

This study also looked at the computer technology infrastructure; including the physical components, connectivity, and training in 2007. A comparison was also made to see how the infrastructure had changed since 1996. Research showed that in order to have strong technology integration, the infrastructure must be kept up-to-date and accessible. Finally the study looked at the impact these changes had on the school. Technology impact looked the level (frequency of) integration, attitudes, and training in the school. Research showed that by having a strong technology strategy, the impact of the technology in the school increases.

Results from the study found that teachers have less anxiety towards using computers in 2007 than they did in 1997. There is an even more negative correlation between the level of anxiety and level of training. Teachers still had an overall positive attitude about the use of computers, but still have some frustrations. Lack of time, not enough of the right kind of training, and frustration over the outdated computers were major areas of concern that were found in the study.

The infrastructure of the school had definitely increased, with more computers and faster computers. Internet connection, e-mail and a Local Area Network also enhanced the technology in 2007. Other devices, such as the interactive whiteboard and increased security features have also been incorporated into the school. Teacher training had also become more specific. The level of training had increased from 1997 to 2007, yet many teachers still feel they could benefit from more training when it comes to using the new technology. Developing different training strategies and providing time and support for the teachers would enhance their technology integration.

Technology has had an impact on the teachers. Findings from this study showed that all of the teachers in 2007 were using the technology to some degree. Major uses include Edline ${ }^{\mathrm{TM}} /$ Gradequick, use of the Internet for lesson development, curriculum planning, and communicating with parents via e-mail. All of these are examples showing the teachers' readiness in adopting the technology, and these applications were not even possible in 1997. Technology will be part of the future and it is important that the school continues to increase its infrastructure, provide support and training, and encourage technology to further enhance the education of the students. This study provided a guideline for the school to plan better ways to further integrate and implement the technology in the future. 


\section{Acknowledgements}

As I reflect on my graduate work at West Virginia University I thought back to the people who influenced me as I worked through the programs. My advisor for my Masters in Instructional Technology, Dr. W. Michael Reed, provided me with a strong understanding of research in instructional technology. With his guidance, I developed the first part of this study. For the early part of my Doctorate in Technology Education, my advisor was Dr. George Maughan, with whom I worked as a graduate assistant and gained valuable experiences.

Dr. Neal Shambaugh, my committee chair and advisor provided the guidance and motivation during the later part of my doctoral studies. He provided wonderful support and feedback as I moved through the competency exams, prospectus, research, dissertation and defense. I would also like to acknowledge the rest of my committee, Dr. David McCrory, whose technology integration courses helped guide the basis of my study. I greatly appreciate him working with me even in his retirement. Dr. Jaci WebbDempsey's qualitative courses provided the framework for my mixed-method approach and I appreciated her guidance in working with my methodology. Dr. Carol Markstrom agreed to be on my committee without even meeting before. I found her perspective from outside of the technology field to be very insightful and I appreciated her suggestions. Dr. Paula Nelson provided support to me when I e-mailed her stressing as I was working through the process. Her encouraging words helped me move forward.

I also want to thank my family for all of their support. My husband, Mark Marple helped take over with the children while I attended my many evening classes and he helped keep things going during the busy times. My daughters, Lindsay and Emily, were actually the reason why I began my graduate studies. After having my first daughter, I wanted to be a stay-at-home mother. By going to graduate school part-time, I was able to be home with my children during the day and take classes in the evening. I finished my Masters while 8 months pregnant with my second daughter, and shortly after that I began my Doctorate degree. By working on the degree slowly, often just one semester at a time, I was able to be home with my children but continue to grow in my field (My youngest daughter is almost 10, so it took awhile to finish). I hope my daughters will learn that they to can do anything they want to do in life if they just stick with it and try.

The people that provided me the most motivation and support through the whole graduate program would be my parents, Peter and Laurie Marshall. My father was the one to first encourage me to sign up to take classes. He also would continue to encourage me to move forward and tease me about taking the "slow road". My mother provided so much encouragement and support at times when I felt like giving up. She would proofread my papers, guide me through the process and just listen when I needed to talk.

I would also like to thank the Middle School principal and teachers that worked with me in completing surveys and interviews and allowing me access to the school for the infrastructure study. I hope this study will prove beneficial to the school in better integrating the technology into their school. 
Table of Contents
Abstract
Acknowledgements
Table of Contents iii
List of Tables $\quad$ iv
List of Figures vii
$\begin{array}{lll}\text { Chapter I Introduction } & 1\end{array}$
$\begin{array}{lll}\text { Chapter II } & \text { Literature Review } & 6\end{array}$
$\begin{array}{lll}\text { Chapter III Methods and Procedures } & 19\end{array}$
Chapter IV Results and Findings 44
$\begin{array}{ll}\text { Chapter V Conclusions, Limitations and Implications } & 143\end{array}$
$\begin{array}{lll}\text { Chapter VI Recommendations } & 164\end{array}$
$\begin{array}{ll}\text { References } & 175\end{array}$
Appendices
A. 1997 Survey/ Report $\quad 180$
$\begin{array}{ll}\text { B. } 2007 \text { Survey } & 201\end{array}$
$\begin{array}{ll}\text { C. Interview Questions } & 207\end{array}$
D. Infrastructure Inventory (1996) 212
E. Infrastructure Inventory (2007) 221 


\section{List of Tables}

Table 1: Research Questions Chart 28

Table 2: Data Analysis for Questions 1-9 of Survey 33

Table 3: Additional Data Analysis for 2007 Survey 35

Table 4: How 1997 and 2007 Data was Analyzed 36

Table 5: Alignment of Interview and Survey Questions 41

Table 6: Correlation of Question 1 and Question 5 (Computer Knowledge and

Anxiety) $\quad 46$

Table 7: Question 9 A: Frequency (Computer Confidence) 48

Table 8: Question 9 B: Frequency (Too Much Emphasis on Computers) $\quad 50$

Table 9: Question 9 C: Frequency (Concerned about Time of Use Computers) 51

Table 10: Question 9 D: Frequency (Not Interested in Learning about

$\begin{array}{ll}\text { Computers) } & 53\end{array}$

Table 11: Question 9 E: Frequency (Learning Computers makes me Effective

$\begin{array}{ll}\text { Teacher) } & 55\end{array}$

Table 12: Question 9 F: Frequency (Computer Literacy should be Learning $\begin{array}{ll}\text { Outcome) } & 57\end{array}$

Table 13: Question 9 G: Frequency (Overwhelmed about Learning/Using $\begin{array}{ll}\text { Computers) } & 59\end{array}$

Table 14: Question 9 H: Frequency (Computer Use to Computer Lab) 61

Table 15: Question 9 I: Frequency (All Classrooms Equipped with Computers) 62

Table 16: Question 9 J: Frequency (All Students Use Internet) 64

Table 17: Question 9 K: Frequency (All Teachers Use Internet) 66 
Table 18: Question 9 L: Frequency (Concerned about having Time to Use Computers)

Table 19: Question 9 M: Frequency (Computers have Limited Application in my Subject)

Table 20: Analysis with Means (converted) for Each Question

Table 21: Self-described Comfort and Anxiety Level

Table 22 : Age range and question 3(Computer Use at School): ANOVA

Table 23: Age range and question 4 (Computer Use at Home): ANOVA

Table 24: Question 1: Frequency (Computer Knowledge)

Table 25: Question 6: Frequency (Computer Training)

Table 26: Computer knowledge and Computer training: ANOVA

Table 27: Question 2: Frequency (Internet Knowledge)

Table 28: Question 7: Frequency (Internet Training)

Table 29: Question 2 and Question 7 (Internet Knowledge and Internet Training): ANOVA

Table 30: Amount of Computer Use at School and Area of Specialization: ANOVA

Table 31: Years of Experience and Training: $A N O V A$

Table 32: Years of Teaching at the School: Frequency

Table 33: Frequency: Question 9 I (Computers in Classrooms) (1997)

Table 34: Frequency: Question 9 I (Computers in Classrooms) (2007)

Table 35: Frequency: Question 9 J (All Students should use Internet) (1997) 
Table 37: Descriptive Comparison of Question 9 K (All Teachers should

Use Internet)

Table 38: Frequency: Question 9 K (All Teachers should Use Internet) (1997)

Table 39: Frequency: Question 9 K (All Teachers should Use Internet) (2007)

100

Table 40: Descriptive Comparison of Question 4 (Home Use of Computers)

Table 41: Analysis for Question 15/ Interview Question 3 (Training Received)

Table 42: Analysis of Question 16 (Training Needed)

Table 43: Frequency: Question 6: (Level of Computer Training) and Question 7: (Internet Training)

Table 44: Frequency: Question 8 (Overall Technology Instruction Received)

Table 45: Summary of Relevant Infrastructure Changes: Document Analysis

Table 46: Frequency chart for all responses to Question 10 (Use of the Computer Technology)

Table 47: Frequency chart of all responses for question 11 (Use of Other Technology)

Table 48: Frequency of responses for survey question 13 and interview Question 2 (Which Technology had the Most Impact)

Table 49: Frequency of responses for survey question 12 and interview Question 1(How has Technology had Impact)

Table 50: Frequency of responses for survey question 17 (How to Make More Effective Use of the Technology) 


\section{List of Figures}

Figure 1: Frequency graph of responses for question 9 A (computer confidence). 46

Figure 2: Frequency graph of responses for question 9 B (Too much emphasis on computers).

Figure 3: Frequency graph of responses for question $9 \mathrm{C}$ (Concerned about time to use computers).

Figure 4: Frequency graph of responses for question 9 D (Not interested in learning about computers).

Figure 5: Frequency graph for responses to question $9 \mathrm{E}$ (Learning computers makes me an effective teacher).

Figure 6: Frequency graph of responses for question $9 \mathrm{~F}$ (Computer literacy should be a learning outcome).

Figure 7: Frequency graph of responses for question $9 \mathrm{G}$ (overwhelmed about learning and using computers).

Figure 8: Frequency graph of responses for question $9 \mathrm{H}$ (Computer use limited to computer lab).

Figure 9: Frequency graph for question 9 I (All classrooms equipped with computers).

Figure 10: Frequency graph of responses for question $9 \mathrm{~J}$ (All students should use Internet).

Figure 11: Frequency graph of responses for question $9 \mathrm{~K}$ (All teachers should use Internet). 
Figure 12: Frequency graph of responses for question $9 \mathrm{~L}$ (Concerned about having time to use computers).

Figure 13: Frequency graph of responses for question $9 \mathrm{M}$ (Computers have limited application in my subject).

Figure 14: Range and means for age range and computer use at school.

Figure 15: Range and means for age range and computer use at home.

Figure 16: Rating of computer knowledge.

Figure 17: Computer training frequency.

Figure 18: Knowledge of Internet application.

Figure 19: Frequency of Internet training.

Figure 20: Comparison of area of specialization and computer use at school. $\quad 88$

Figure 21: Comparison of technology training and years of teaching.

Figure 22: Percentage of have been at the school 10 years or more.

Figure 23 and Figure 24: Comparison figures of 1997 and 2007 for question 9 I (Computers in Classrooms).

Figure 25 and Figure 26: Comparison figures of 1997 and 2007 for question $9 \mathrm{~J}$ (Students should use Internet).

Figure 27 and Figure 28: Comparison figures of 1997 and 2007 for question $9 \mathrm{~K}$ (Teachers should use Internet).

Figure 29 and Figure 30: Comparison graphs of computer use in 1997 and 2007.

Figure 31 and Figure 32: Comparison figures of computer knowledge for 1997 and 2007. 
Figure 33 and Figure 34: Comparison figures or computer training for 1997 and 2007.

Figure 35 and Figure 36: Comparison figures of Internet knowledge for 1997 and 2007.

Figure 37 and Figure 38: Comparison figures of Internet training for 1997 and 2007. 


\section{Chapter I}

\section{Introduction}

\section{General Background of the Topic}

Computers began to be widely introduced into American schools in the early 1990's. Many teachers in the classrooms had not been trained to use this computer technology in schools and possessed high anxiety about using this new medium. By the mid-1990's many schools also began to be connected to the Internet, opening up a whole new teaching/learning tool. Teacher training on the computers played a significant role in the implementation of computers and technology in the schools.

In 1997, the researcher conducted a study which looked at technology integration at $\mathrm{ABC}$ Middle School ${ }^{*}$ in West Virginia to assess the teachers' readiness to adopt computer/telecommunications technology within their teaching activities and to determine their specific needs for training in this area. This research project helped to develop a baseline of the teachers' readiness, which could then be used to develop future training programs. The study looked at how the implementation of computers was influenced by the level of computer anxiety, prior computer experiences, and the average age and experience level of the population (See Appendix A). Additionally, a technology infrastructure study of the school was conducted in 2006 (See Appendix D).

\footnotetext{
* the name of the school, county and personnel have been changed to ensure confidentiality.
} 
Briefly, results from the initial study showed the need for increased training in technology, because teachers were not readily integrating the computer and instructional technology into the curriculum. Teachers were also not using the technology in the schools often and felt intimidated about the technology, with high levels of computer anxiety. The infrastructure at the time showed the school had computer labs, several computers in the classroom, and Internet connection, but no e-mail capabilities.

This dissertation continued the research on ABC Middle School by utilizing an expanded follow-up study. The goal of the follow-up research was to compare how the teachers respond to the survey in 2007, as compared to ten years earlier. Such a comparison helped show the long-term effects of teacher training and teacher implementation of technology. The technology infrastructure study from 1996 and 2007 was also compared. The question of interest was: What is the scope and nature of infrastructure changes that have been taken to further the integration of computer and instructional technology into the curriculum?

In addition to the survey administered to all participating teachers at the school, the research gathered further information about technology training and adoption strategies the school had conducted using qualitative research techniques. Interviews were conducted with the County Technology Director to discuss technology training and adoption strategies including what types of training workshops have been held for teachers at ABC Middle School and elsewhere. Additional interviews conducted with the school principal and a representative teacher from each grade level (5-8) helped to obtain information about measures that had been taken and their assessment of efforts to enhance the integration and use of computer technology in the school over the past ten 
years. Open-ended questions in the survey, which align with the interview questions, provided an opportunity for all teachers to respond to these questions to a lesser extent.

The baseline data collected in 1997 and 2007 provided a view of where this school has been and where it is going, in terms of computer technology integration and use. It was worthwhile to study the evolution of computer implementation and training and could help shape the future of both pre-service and in-service computer training courses.

Need for the Study

The integration and use of computer technology in schools is a relatively new initiative that is undergoing constant and rapid change. This study represented a unique opportunity to collect empirical data that measures the scope and nature of changes in computer technology integration and adoption in a West Virginia middle school in 1997 and again in 2007. To the extent that ABC Middle School was typical of other middle schools in the integration and use of computer technology, this study provided data that will help contribute to the development of technology training and adoption strategies. Additionally, this study continued to research this area to provide school administrators and faculty at $\mathrm{ABC}$ Middle School with some meaningful data on what the school was doing. Teachers and the administrator at the school expressed interest in the study and wanted to see the finished report from this study. This was a unique study because often studies are done at one point in time. The nature of this study goes beyond the "temperature check" to measure changes that have occurred over a decade. 


\section{Purpose of the Study}

This study determined if any changes in technology integration and adoption of computer technology had taken place at ABC Middle School from the initial pilot study in 1997 and the follow-up study in 2007. The research analysis looked for changes in the teachers' computer anxieties, attitudes, and computer use from the previous study. Additional research data were gathered on the computer technology infrastructure and how that has changed over the past 10 years. The study could help provide a guide to what areas of training, infrastructure or support are still needed in the school.

\section{Research Questions and Hypotheses}

Research question 1. What are the differences in readiness of the classroom teachers from 1997 and 2007 in their ability to integrate instructional technology within their teaching activities? (Readiness is defined by their ability and willingness to use the computer technology as a learning tool in the classroom. Factors used to determine readiness include computer anxiety, prior computer experiences, and the average age and experience level of the population).

Null Hypothesis: There was no difference in the readiness of the classroom teachers from 1997 and 2007 in their ability to integrate instructional technology within their teaching activities.

Alternative Hypothesis: Teachers showed a significant difference in their ability to integrate instructional technology within their teaching activities from 1997 to 2007.

Research question 2. What are the differences in the technology infrastructure at this school from 1997 and 2007 with the changes in support, physical changes, and training over the past 10 years? (Infrastructure is defined as the internal and external 
technology components that make up the school technology system. This includes everything from the wiring and Internet connection to the hardware and software and other peripheral associated with the computer technology and user training of these systems.)

Null Hypothesis: There was no change in the technology infrastructure at this school from 1997 and 2007.

Alternative Hypothesis: There was a change in the technology infrastructure at the school from 1997-2007.

Research question 3. What impact has technology integration had on administrators, coordinators, and teachers who are adopting, adapting, and utilizing the new technology? (Impact is defined as the influence the technology may have had on the school and how (or if) the school is operating differently because of the introduction of these new technologies.)

Null Hypothesis: Technology integration has had no impact on administrators, coordinators, and teachers who are adopting, adapting, and utilizing the technology.

Alternative Hypothesis: Technology integration has had a positive impact on administrators, coordinators and teachers who are adopting, adapting, and utilizing the new technology. 


\section{Chapter II}

\section{Literature Review}

\section{Background}

In 1990, West Virginia launched a statewide initiative to integrate and promote technology into their schools, which were struggling to meet their goals. Computers were integrated into all grade-level classrooms and teachers were given extensive training and support in the use of the technology. At the time, West Virginia became a leader in technology in schools and their scores on National Achievement tests jumped from the $33^{\text {rd }}$ to the $11^{\text {th }}$ place (Zuckerman, 2005, p. 68). West Virginia saw increases in the Stanford 9 test scores, with lower achieving students having the greatest gain. Teachers in West Virginia also reported more enthusiasm towards the technology compared to other states (Schacter, 1999).

Other smaller scale studies also help demonstrate the value of integrating technology into the schools. A study done by Taylor, Casto and Walls (2007) looked at student learning with and without technology integration. Results showed that in elementary and secondary students, the group that had technology integration showed significant pre- to post- test gains over the non-technology group. O’Connell and Phye (2005) studied low socio-economic students in math and reading with and without technology. There were significant gains (63.6\% variance) in the group that received technology over the control group. In a survey of teachers, $65 \%$ said the students' performance improved with the use of classroom computers (Bowker Publishing, 2006).

The literature shows that integrating technology into the classroom promotes increased learning. The U.S. Department of Education has adopted this idea in several 
ways. In 1999 they developed the PT3 Federal Program (which stands for Preparing Tomorrow's Teachers to Use Technology). This initiative provides grants to help schools transform teacher education by helping integrate technology throughout teaching and learning. This program has allowed many schools to develop innovative strategies (U.S. Dept. of Education, 1999). The U.S. Department of Education also included technology in the No Child Left Behind (NCLB) (U.S. Dept. of Education, 2001).

The "No Child Left Behind" act (Title 11 D: Enhancing Education through Technology) discusses the importance of technology and education by "promoting initiatives that provide school teachers, principals, and administrators with the capacity to integrate technology effectively into curricula and instruction...through such means as high-quality professional development programs" (U. S. Dept. of Education, 2001, sec 2402.a4).

West Virginia's technology initiative was so successful because it provided an all encompassing integration of the technology, trained the teachers on how to use the technology, and provided the infrastructure and funding to help meet the needs of the schools. This is a prime example of how technology integration is important in the schools.

This study looked at these aspects in a more in-depth, case study of one school in West Virginia, ABC Middle School. This literature review discusses the framework of the constructs of the research.

\section{Readiness}

Many factors determine how effectively computers are integrated into the classroom. One of the key areas that need to be addressed in order to have a successful 
technology program in the schools is teacher training. Several factors related to teacher training that can have an effect on the implementation of computers include computer anxiety, prior computer experiences, and the average age and experience of the population.

This research re-examined findings from the previous study to look for changes in attitudes and the teaching experiences these teachers are now implementing after numerous training and experience opportunities. These findings showed the school how far they have come in successfully implementing the technology, as well as showed them areas that still may need improvement. Following is what the literature says on this area.

The U.S. Congress Office of Assessment reported that by helping teachers to "effectively incorporate technology into the teaching and learning processes is one of the most important steps the nation can take to make the most of the past and continuing investments in educational technology" (Christensen, 2002, p. 411). Connell and Johnson (2004) found that when faculty were provided with strong leadership and appropriate opportunities, they embraced the implementation of the new ideas. Zuckerman (2005) stated that it is "critical for teachers to join the (technology) revolution - to adapt information technology to the methods and content of instruction" (p.68).

For schools to spend millions of dollars on infrastructure and computers with only a hope that the teachers can effectively use the technology is not a wise decision. Barlow (2005) pointed out that before placing millions of dollars into computers and technology, it is important to have a clear aspect of how the teachers will use the technology. He states that you should "Know How First" when it comes to implementing instructional technology (Barlow, p. 67). 


\section{Effects of Teacher Training}

Providing teacher training is important, but for the training to lead to implementation and adoption, it is essential to look at how the training will be most effective. The following literature looks at teacher training and ways to make it effective. Wang (2002) discussed teacher training by stating, "Teaching development seems to require the teaching profession to make changes at an unprecedented rate" (p.155). Through history, there have been few changes in education that have had such an overall impact on all aspects of the schools as instructional technology has. In the period of a little over a decade (1997-2007), teachers have gone from traditional teaching methods with a chalk board and paper, to interactive whiteboards and Power point slides. Because of this rapid increase in technology adoption, teachers have received many hours of teacher training.

The research shows that computer technology should be introduced into the schools through integration into the curriculum and not seen as a separate entity. The only way for this to happen is to educate teachers in using computers and technology. They need to feel comfortable in using the computers and see the value of integrating the technology into the curriculum. In Daughterty and Boser (1993), they state that, "The effective implementation of a technology education program requires that the teacher develop new technological skills in addition to changing educational philosophy, curriculum, and instructional methods" (p. 9). Hanson, Burton and Guan (2006) discuss the importance of integrating and collaborating technology in the core subject areas to provide enrichment to help meet the NCLB goals of 2006. Shaw (2006) shows the importance of including professional development with the technology training for the 
teachers. They need to know how to operate the technological devices as well as how to integrate them into the lessons and content.

Through the course of this research study, another aspect of teacher training also came into play. After the Internet explosion took place, teachers now also face the task of not only using the new technology, but ensuring the children use it safely. This became a hot topic in the late 90's and still remains a concern today (McLester \& Poftak, 2005).

From the research, one factor that was clearly represented was the need to have in-service programs that are relevant to the teacher's specialization area. Results from a 10-year study on computer training for pre-service teachers recommended that "majorspecific courses incorporate major-specific computer uses, rather than all students receiving computer-related instruction via general computer courses" (Reed, Ervin \& Oughton, 1995, p. 22). Another study based on looking at online professional development found that "faculty must acquire the skills needed to use technology resources in ways that are relevant to their work (Bush, 2005, p. 18). Providing generic computer training programs for everyone limits the scope of the areas covered in the inservice. Content specific software and applications cannot be as fully discussed in a whole group program as it could in a specialized program.

One way to assist in the implementation of technology would be to develop inservice training or programs that are relevant. Such training programs would provide real-life, hands-on training that shows good modeling and practice for the implementation of computer technology to be effective. A study done by Bitter (1994) discussed the importance of having "real-life" experiences in teachers' training programs. In his study, 
the participants were shown video systems modeling actual classroom teachers using the teaching strategies they were learning. Results from surveys taken after this workshop showed positive responses to this teaching strategy. The participants learned novel teaching strategies as well as positive and negative examples of teaching strategies used in their areas.

Other studies showed positive results in regard to teacher training. This included a longitudinal study of Hutchens and Cronin (2004) that found significant gains in the teachers' knowledge and skill level in technology after having training programs implemented and by providing them with the needed software and hardware. Similar results were found in the research done by Shick (1996) who found that "(a)fter training, the staff had a very positive attitude towards the integration of technology into the classroom curriculum” (p. 4).

Additional studies on technology training include Groves and Zemel, (2000) whose action research revealed that "in order to use technology in teaching, respondents wanted accessible hardware, training, and discipline-specific media that is easy to use" (p. 57). Based on their research, they proposed one suggestion to accomplish this was to develop a web-based resource to help with training, resources, and questions.

When teachers were asked what would help them to be better teachers, they revealed a repeated request for in-depth training on the emerging technology (Turner, 1996, p. 208). For many of the veteran teachers, instructional technology was not something they had in their pre-service training and they continue to feel the need to learn more about the technology. 
In Wang's (2002) case study, she discussed the need for training which promotes personal, conceptual and pedagogical change. She emphasizes the importance of supportive administrators, colleagues and staff in having successful adoption of technology. To have any real change the teachers have to want change and not just go through the motions.

A new aspect in teacher training that had developed in the past decade has been the introduction of online professional development courses. This was even discussed in the NCLB when promoting "the ongoing professional development of teachers, principals, and administrators by providing constant access to training and updated research in teaching and learning through electronic means" (U. S. Dept. of Education, 2001, sec. 2402.a5). Distance learning courses can also help support the idea of having "one on one" training, which is mentioned as a preferred method over the "train the trainer" who then goes back to the school to teach everyone else (Eaton, 2005).

With just a little technological knowledge, teachers often are motivated enough to learn about new advances. They want to learn about new and better ways to teach, as well as be able to better relate to the students (Kopkowski, 2006).

\section{Anxiety and Attitudes}

Initial anxiety towards instructional computing slowly shifts to different areas of concern as some of the technologies are being accepted and adopted with a lessened anxiety. A teacher who may have had anxiety about using a word processing program or doing a search on the Internet may now feel comfortable with that. But, now s/he may be more apprehensive about online grade book spreadsheets, or distance learning courses. 
Several studies look at attitudes and anxiety in computer usage. Smith (1986) found that elementary teachers were significantly more confident than junior high or high school teachers. Interestingly, he also found that students were more confident than the teachers, where the teachers' efficacy scores were found to be significantly and negatively related to the student scores. Smith also found that there were no significant differences between males and females in the attitudes or sense of confidence when it comes to their ability to use the computer. Rovai and Childress (2003) found that "given technology availability and requisite skills and knowledge to use it, performance may not occur without positive attitudes about computers, particularly high computer self-efficacy and low computer anxiety" (p. 226).

One study which looked at 350 primary and secondary teachers found that computer competence and anxiety were highly correlated $(r=-0.78)$. They found that "computer anxieties were inversely related to the quality of prior computer learning experiences, and to the extent of current school support for computer usage" (Bradley, 1997, p. 226). This relationship was also found in the 1997 pilot study, which found a correlation with teacher training and teacher anxiety (Appendix A).

Christensen examined the relationship between readiness and anxiety and found that "needs-based technology integration education is shown to have a rapid, positive effect on teacher anxieties, such as computer anxiety, perceived importance of computers and computer enjoyment" (Christensen, 2002, p. 411).

Research shows the importance of attitudes and anxiety in regards to computer usage. Attitudes and anxiety can be considered one factor to determine teachers' readiness in adopting the computer technology. 


\section{Infrastructure}

Even with the best training and curriculum development, the technology usage can only be implemented with a strong technological infrastructure. In a study of teachers, $55 \%$ cited that a lack of access to computers was a chief obstacle in their ability to fully integrate computers in education (Bowker Publishing, 2006). Kopowski (2006) explains how staying current with access to the rapidly changing technology is very exciting and motivating for the teachers. Shaw (2006) also mentioned that the infrastructure has to be reliable if the teachers are going to willingly adopt the technology into the classroom.

To access the latest technologies and the Internet, computers and software need to be upgraded to accommodate the advances. According to a study done by the Educational Testing Services, the total cost of technology in the late 1990's was around $\$ 30$ billion ( $\$ 70$ per pupil) (Coley, Cradler \& Engal, 1998). A more recent study from Utah placed the amount of technology cost for infrastructure, hardware, software and training at around $\$ 3,757$ per pupil, clearly showing a significant increase (Gartner, 2003). With these significant costs in place, it is important to ensure that proper infrastructure is in place and that the technology in the schools is effective.

When looking at the infrastructure, there are several key questions and indicators to help determine the infrastructure's effectiveness as mentioned in Schmitt (2002) for the Technology in Schools Task Force.

(a) Is the equipment present in instructional settings?

(b) Is the equipment available for use by students?

(c) Is the equipment available to teachers? 
(d) Is the equipment available for use by administrators and support staff?

(e) Does the technology infrastructure have the capacity to support the school's technology needs? (pp. 32-36).

In 1994, only 35 percent of schools in the United States had access to the Internet. By comparison, in the fall of 2003, nearly 100 percent of schools had access to the Internet (National Center for Education Statistics, 2005). The adoption rate of the Internet has rapidly increased in less than a decade of time. American schools have done a major transformation in this time frame and this study looks at how significant this change has been for ABC Middle School.

Infrastructure was discussed several times in the No Child Left Behind act (Title 11 Part D, Enhancing Education through Technology). In section 2402, goals include; "To assist States and localities in the acquisition, development, interconnection, implementation, improvement, and maintenance of an effective educational technology infrastructure in a manner that expands access to technology for students (particularly disadvantaged students) and teachers" (U.S. Dept. of Education, 2001).

In 2005, the XYZ County Schools Office of Technology, (the county where ABC Middle School is located), conducted an overview of the technology capabilities of the county. This online review provided many facts about the current status of technology in the schools. Listed below are several facts from their website;

- There are 3,500 computers system-wide.

- All XYZ County school classrooms have Internet access with at least one T1 line in each school. 
- Video conferencing equipment is permanently installed in the county's three middle schools and portable equipment is available for use at all schools.

- Media centers are automated.

- All county schools are equipped with $21^{\text {st }}$ century learning tools including video projectors, interactive white boards, palms, electronic subscriptions such as online databases, encyclopedias, and web-based and server-based curricular software.

- All XYZ County Middle and High Schools and some elementary schools post students' grades online and provide individual teacher web pages to enhance parent/teacher communications. (XYZ County Schools Website, Retrieved November 20, 2005, (http://boe.xxxx..k12.wv.us/district info/index.html). Another area of infrastructure that is often overlooked is the need for maintenance and replacement of the technology as the equipment ages (Friedman \& Erickson, 2000). The authors make a good point; if you have the fastest, best quality computers in place but have no one to fix them when a problem arises, the computers become useless. This study looks into this aspect as part of the infrastructure inventory.

\section{Impact of Technology}

One must look at how the technology integration, training, and attitudes towards the technology have had an impact on the schools. In a survey of teachers in the Electronic Education Report, 54\% of teachers said that computer technology is changing how they teach "a great deal" (Bowker Publishing, 2006, p. 5). One poor achieving school raised reading scores by $124 \%$ after developing a technology strategy which provided measurable and real impact on the students' learning. This school was able to 
accomplish this by using intensive research-based curricula with technology integration and intensive staff development (Eaton, 2005).

In explaining the impact of computer technology in art education, Wang (2002) stated, "I foresee the power of computer technology as having an even greater impact on art, science, and education that it has now. However, that technology in itself will not change education; what matters is how it is used" (p. 163). It is important to focus not just on getting the infrastructure in place, but also to provide the training and support to encourage and promote utilization of the technology in an educational and meaningful way.

The school system of ABC Middle School has earned the "Making it Happen" award, which was given to the County Schools' Office of Technology in 2003. This award is given by the International Society of Technology in Education (ISTE), which is "an internationally recognized awards program for educators in the field of educational technology integration in $\mathrm{K}-12$ schools. The program identifies and rewards educational technology leaders around the world for their commitment and innovation" (ISTE, 2005). They also received the "Caperton Technology Learning Award" in 2004 (ABC County, 2005). This award was established by the (former), Governor Caperton to "recognize and honor those who have made a difference through the use of technology in K-12 schools" (West Virginia Dept. of Education, 2005).

This research provided some insight into the impact that technology has had on ABC Middle School. The research goal was to look at the changes in technology over the past decade. It explored changes in teacher anxiety and attitudes towards using the technology. Did changes in the anxiety affect the teachers' use of computers as part of 
instruction? What impact did teacher training in technology have for the faculty at this school? How has the infrastructure changed over the past 10 years to accommodate and facilitate the changes in the technology? These answers were looked at in this study. 


\section{Chapter III}

\section{Methods and Procedures}

\section{Research Strategy Overview}

The development and understanding of the research strategies and design are the roadmap and framework of any research study. This case study looked at a specific school (ABC Middle School) and compared its progress in technology integration 10 years later. The study used several elements of research design, making it a mixed methods design, which is a blend of qualitative and quantitative research methodology. The design used survey instruments as a statistical tool to analyze differences in data from the 1997 and 2007 studies (Question 1 and Question 2). It further developed the findings by conducting qualitative interviews (Question 3). Results from the qualitative investigation provided more insight and information and helped to explain the numerical findings more clearly. Data analysis was also used to compare infrastructure studies conducted in 1996 and 2007.

\section{Unit of Analysis}

The research was conducted as a case study of ABC Middle School, as a unit, and how it has changed in technology use over a ten-year period from 1997 to 2007 . The unit of analysis was the technology use at the school itself, and not the individual teachers. While some of the individual teachers changed in these 10 years, the basic principles, philosophies, socio-economic status, and student population did not change significantly in this time frame. 
The study did not factor in all aspects that could have affected any changes in the teachers over this decade. The study looked more at what changes took place, rather than exactly which factors caused the change to take place. A similar study was conducted by Hutchens and Cronin (2004), in which looked at a population over a shorter period of time (3 years) with a larger number of participants (580). This study used two quantitative assessment surveys and the qualitative structured interviews.

Since computer technology was first introduced into the school several decades ago, there have been some significant changes compared to the way the technology was first used. Educational pedagogy and infrastructure are changing as this adaptation and adoption occur. Looking at a specific time and place helps to see how the school is doing at that time and place but does not provide the scope of information that this study does when comparing at the school during two separate time periods a decade apart.

\section{Mixed Method Design}

This study was a mixed methods design. "A major advantage of mixed methods research is that it enables the researcher to simultaneously answer confirmatory and exploratory questions and therefore verify and generate theory in the same study" (Tashakkori \& Teddlie, 2003, p. 15). The principles of conducting a mixed methods design for this research for this doctoral dissertation were discussed in the Mixed Methods Handbook, in which "students want to simultaneously accomplish two goals; (a) demonstrate that a particular variable will have a predicted relationship with another variable and (b) answer exploratory questions about how that predicted (or some other related) relationship actually occurs" (p. 15). 
By looking at the research in multiple ways, the research also employed the power of triangulation; "borrowing and combining distinct elements from pure or coherent methodological strategies can generate mixed inquiry that illustrate variations on the theme of triangulation" (Patton, 2002, p. 248). This study used triangulation methods throughout the results and findings section. The statistical data helped to understand the overall picture of the population, but the quantitative analysis answered the "why" behind the statistics. There were three forms of data implemented in the study: survey questions, interview/open ended written responses, and document analysis.

The mixed method design gave this research a more in-depth look at how the school utilized and adopted the technology. The survey provided statistical information that was used to determine correlations and significances in the data. The qualitative interviews and open-ended questions provided a chance to hear the participants' own words about their anxiety or comfort towards the technology and the frequency and usage of specific technology in their classroom. Additionally, teachers had a chance to express opinions and suggestions about the technology, which was used to provide insight into what the teachers want and need to help them integrate the technology. This mixedmethod approach helped formulate a clearer overall picture of the process of technology adoption and utilization in ABC Middle School.

\section{Pilot Study Results}

The dissertation research was an extension of the research study conducted in 1997 by the same researcher. The 1997 pilot study consisted of two parts. The first part consisted of a survey on computer attitudes and readiness in instructional technology given to the teachers at ABC Middle School, in West Virginia. At the time the teachers 
had limited computer training and they minimally used instructional technology as a learning tool or for evaluative purposes. The pilot study revealed a level of high anxiety in using the new technology, and concluded that additional technology training would be needed.

The second part of the pilot study was a technology infrastructure study of the school. Results of the infrastructure analysis looked at what types of hardware and infrastructure the school had in place and what it expected to have in the future. The findings showed that the school had a T-1 direct Internet line wired but not yet connected. The school also had a computer lab with an LCD panel. Teachers did not have the capabilities to have e-mail yet but would when the Internet connection became operational. The school did not provide them with an e-mail account and they did not have a web site nor could grades be posted online.

\section{Follow Up Study}

With the dissertation, a follow-up investigation was conducted to study the school's instructional technology development. The study re-administered the survey of computer attitudes and readiness in instructional technology as well as the impact this has had on the school. It also analyzed the school's technology infrastructure. In addition to the survey, the researcher included interviews of pertinent participants, documents, and observations, to gain a greater understanding of instructional technology's role in the school.

\section{Research Questions}

1. What are the differences in readiness of the classroom teacher from 1997 and 2007 in their ability to integrate instructional technology within their teaching activities? 
The Dependent Measure was the readiness of the teacher in utilizing and adopting the instructional technology. This was evaluated using comparisons of computer anxiety scores, which were determined by mean differences and frequency of responses from 1997 and 2007.

The Independent Measures were the mean differences in the years of teaching experience and the age range of the teachers in 1997 and 2007, computer knowledge, computer use, willingness to use technology and frequency of computer use. Time (from 1997 and 2007) was also a measure used to determine if any change has taken place in the population over the past decade.

The study also looked at the frequency in prior computer experiences and prior computer training. A comparison was done between the scores from the time between 1997 and 2007 using a mean comparisons.

2. What are the differences in the technology infrastructure at this school from 1996 and 2007 including the changes in support, physical changes and training over the past 10 years? Technology infrastructure is defined as the technological hardware (including computers, software, peripherals, labs, etc.) and the Internet connectivity (including Internet lines, phone lines, modems, wires, etc.)

A comparative study was used to compare the changes in technology infrastructure over the past decade. This quantitative analysis provided statistical data to help demonstrate the changes in terms of amounts of hardware, increases in bandwidth, and amounts and types of hardware available. The items of change included the following areas: external communications (satellite, phone lines, Internet connections etc.), internal technology (hardware, computers, peripherals, software, fax machines etc.). 
Training was addressed by looking at the survey questions and interview questions related to the overall level of technology training received, including specific questions on computer application and Internet training. Teachers were also asked to identify in what areas they would like more training to make them a more effective teacher.

A document analysis was conducted comparing the infrastructure analysis done in 1996 with a similar analysis done in 2007 . Additional documents and websites relating to infrastructure were also analyzed.

3. What impact has technology integration had on administrators, coordinators, and teachers who are adopting, adapting, and utilizing the new technology?

The survey also asked specific questions about what technology has had the most impact. Responses from the survey also helped understand individual usage and frequency of the specific technology devices and applications. Categories for the survey included specific use of Internet-based applications (such as e-mail, instant messaging, online research, etc.) and use of technology devices (such as fax machine and electronic white boards). Using the frequency data helped to understand the scope of the impact the technology has already had on the school, in relationship to how much adoption and integration had already occurred.

Conducting interviews (qualitative) further helped reveal how the technology integration has impacted the school, faculty and administration. Interviews provided a range of data not available on the survey. 
Technology Integration 25

\section{Participants}

The participants for the study included the professional staff from ABC Middle School, the administrator (principal) of the school, and the XYZ County Schools' Office of Technology Director. Each member of the professional teaching staff was asked to voluntarily participate in some capacity for the study.

$\mathrm{ABC}$ Middle School is a public school located in an urban fringe of a mid-sized city. The school is a fifth through eighth grade school with 39.5 teachers and approximately 572 students. The ethnic student make-up is $97 \%$ white, $1.9 \%$ black and $1.9 \%$ Asian. The school is classified as a "low poverty" school with less than $25 \%$ of the students receiving free or reduced lunch. (National Center for Education Statistics (2005), Retrieved 3/26/2007, http://nces.ed.gov).

In the 1997-1998 West Virginia Report Card, $84.3 \%$ of the teachers at ABC middle school attained at least a Master's degree. There were no teachers with a doctorate degree. The average number years of teaching experience for the professional staff was 13.2 years (West Virginia Dept. of Education, 1998)

From the 2005-2006 West Virginia Report Card, $71.4 \%$ of the teachers have a master's degree plus additional hours. There are no teachers with a doctorate level degree. The average years of teaching experience for the professional staff was 17. 6 years (West Virginia Dept. of Education, 2006).

Approximately $40 \%$ of the teachers at $\mathrm{ABC}$ Middle in 2007 were also teaching at the school during the first study. The professional staff was similar from the 1997 study and the 2007 in terms of educational level. This study was looking at the school itself 
over the past decade, so variances in the teachers over that time period were not significant.

Technology infrastructure and integration have a high value at ABC Middle School and at the county level. This school may be unique in regards to the resources and support available that schools in other counties may not have. All middle and high schools in the county have a "Technology Contact" teacher who helps assist the teachers with technology training, support, and keeping the technology up and running. This teacher has two periods a day to assist with technology needs and teaches the students the remainder of the day. The school also offers several technology classes that the students can take as electives; including Basic Computers, Online Yearbook Development, Photoshop, and Broadcasting. Many of these course offerings are unique for ABC Middle and are not offered at other Middle Schools in the county.

The county provides technology support for the school through the Technology Integration Specialist (TIS). The TIS positions are funded through a grant the county received from the EETT Program (Enhancing Education Through Technology), a federally funded program through the No Child Left Behind Act of 2001. The TIS specialists are teachers who have had extensive training in technology integration. The role of the TIS is to assist classroom teachers in helping integrate technology into the curriculum and to encourage academic achievement through technology. Support from the TIS should help students cross the Digital Divide and be computer literate by $8^{\text {th }}$ grade (West Virginia Dept. of Education, 2007). ABC Middle school shares a TIS teacher with the other middle schools in the county. The TIS teacher often comes to the school one morning every few weeks to help provide support to the school. The county also 
provided staff development opportunities that the teachers can register for during the summers or evenings (MCS, 2007).

Throughout the study from 1997 to 2007 , the county had continued to add more and more technology into the school infrastructure. The county tried to keep up with the latest trends in technology and tended to be ahead of the curve in technology integration into the schools.

All professional staff were asked to complete the survey. Purposefully selected individuals were also asked to participate in the qualitative interview. This group included the people who play or have played an important role in technology integration in the school, such as the principal, who oversees the current and future technology plans; and the Director of the XYZ County Schools Office of Technology, who oversees technology purchases, training, and implementation for the county. Additionally, a teacher from each grade level participated in the interview, with a variance in area of specialization, age range, and years of experience.

\section{Role of the Researcher}

As a qualitative researcher, one must look at one's personal role in the research and any bias one may bring into the study. Previously, I worked as an elementary education classroom teacher as well as a computer teacher in a public school in another state. Part of the duties as a computer teacher included providing technology support and training to fellow teachers at the school. I feel that computer technology integration can provide a valuable tool for education's future. I also have seen first hand the effects of computer anxiety among the teachers and how they were afraid to try new things in fear 
of "breaking" the computer. There was also a level of intimidation with some teachers who felt that the students may know more about the computers than they do.

While the researcher's personal experiences have been directed towards promoting instructional technology in the classroom, I feel that it did not impact the research. The goal of the research was not to determine if technology integration was a "good or bad" idea, but to determine how the technology integration was being implemented in this particular school. As I was not working in the school system at the time of this investigation and had no influence on this school, teachers, or administrators, I did not pose any conflict of interest in doing this research.

\section{Data Sources and Analysis}

This table summarizes the methodology for the study. For each research question, the participants, data source and analysis methods are briefly described. A more detailed description follows of each data source and method follows.

Table 1

\section{Research Questions}

\begin{tabular}{|l|l|l|l|}
\hline Research Questions & Participants & \multicolumn{1}{|c|}{ Data Sources } & \multicolumn{1}{c|}{ Analysis } \\
\hline $\begin{array}{l}\text { 1. What are the } \\
\text { differences in } \\
\text { readiness of the } \\
\text { classroom teachers } \\
\text { from 1997 and 2007 } \\
\text { in their ability to } \\
\text { integrate } \\
\text { telecommunications } \\
\text { within their } \\
\text { teaching activities? }\end{array}$ & All faculty & $\begin{array}{l}\text { Computer Survey } \\
\text { (Modified from 1997 } \\
\text { survey) }\end{array}$ & $\begin{array}{l}\text { Correlation } \\
\text {-Is there any relationship } \\
\text { between computer } \\
\text { (Snowledge and computer } \\
\text { Anxiendix A - 1997) } \\
\text { Appendix B - 2007 }\end{array}$ \\
& $\begin{array}{l}\text { Questions 1 -7 } \\
\text { Assessment of levels of } \\
\text { computer training and } \\
\text { usage. }\end{array}$ & $\begin{array}{l}\text { Mean Score/Frequency } \\
\text {-Computer anxiety and } \\
\text { willingness to adopt the } \\
\text { technology. }\end{array}$ \\
\hline
\end{tabular}




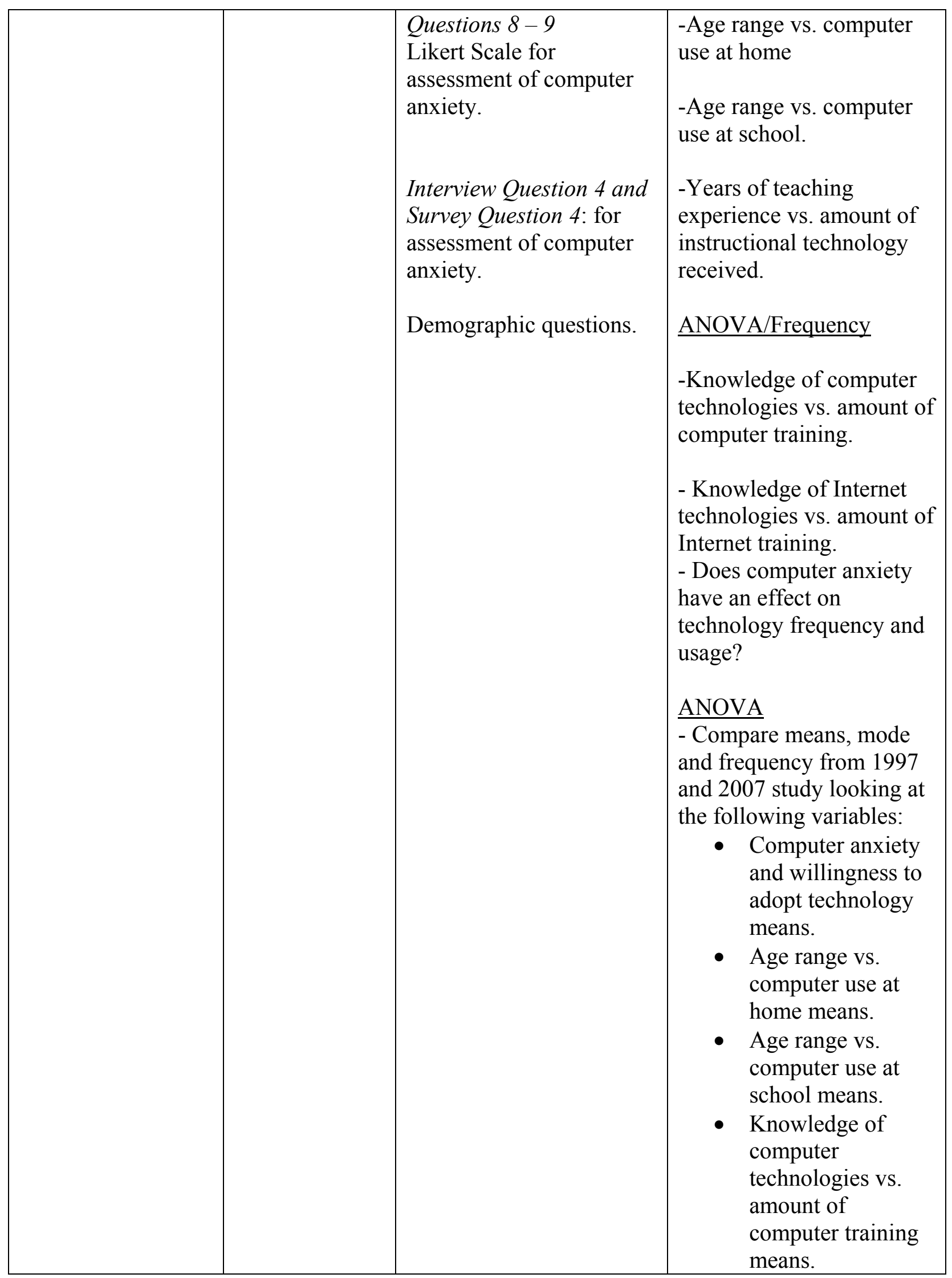




\begin{tabular}{|c|c|c|c|}
\hline & & & $\begin{array}{l}\text { Knowledge of } \\
\text { Internet } \\
\text { technologies vs. } \\
\text { amount of Internet } \\
\text { training means. }\end{array}$ \\
\hline $\begin{array}{l}\text { 2. Compare the } \\
\text { differences in the } \\
\text { technology } \\
\text { infrastructure at } \\
\text { this school, } \\
\text { including the } \\
\text { changes in support, } \\
\text { physical changes } \\
\text { and training in } 1997 \\
\text { and } 2007 .\end{array}$ & $\begin{array}{l}\text {-All faculty, as } \\
\text { part of the } \\
\text { survey. } \\
\text { - Administrator } \\
\text { - County } \\
\text { Technology } \\
\text { Director }\end{array}$ & $\begin{array}{l}\text { - Interview question } 13 \\
\text { and open ended survey } \\
\text { question } 3 . \\
\text { - Open-ended survey } \\
\text { question } 16 . \\
\text {-Other relevant data from } \\
\text { gathered in interview. } \\
\text { Document Analysis } \\
\text {-Review infrastructure } \\
\text { analysis of school in } \\
\text { 1996, } 2007 \text { using same } \\
\text { infrastructure format } \\
\text { (Appendix D - 1996) } \\
\text { (Appendix E - 2007) } \\
\text {-Review of additional } \\
\text { documents. }\end{array}$ & $\begin{array}{l}\text { Training and Support } \\
\text {-Analyze interview } \\
\text { question } 3 \text { and open-ended } \\
\text { survey } 15 \text {. Analyze, } \\
\text { categorize and summarize } \\
\text { responses in table and } \\
\text { incorporate relevant } \\
\text { quotes. } \\
\text { - Compare results to } \\
\text { statistical analysis results } \\
\text { from survey question } 6,7,8 \\
\text { Physical Changes in } \\
\text { Infrastructure } \\
\text { - Compare infrastructure } \\
\text { from } 1996 \text { study and } 2007 \\
\text { study. } \\
\text { - Develop a comparison } \\
\text { table of relevant changes } \\
\text { from both infrastructure } \\
\text { studies. }\end{array}$ \\
\hline $\begin{array}{l}\text { 3. What impact has } \\
\text { technology had on } \\
\text { administration, } \\
\text { coordinators, and } \\
\text { teachers who are } \\
\text { adopting, adapting } \\
\text { and utilizing the } \\
\text { new technology? }\end{array}$ & $\begin{array}{l}\underline{\text { Selected }} \\
\underline{\text { Interview }} \\
\underline{\text { Participants }} \\
\text {-Administrator, } \\
\text {-Teacher } \\
\text { From each } \\
\text { Grade (5-8), } \\
\text {-County } \\
\text { Technology } \\
\text { Director } \\
\text { Survey }\end{array}$ & $\begin{array}{l}\text { Technology Integration } \\
\text { Survey } \\
\text { Questions New to } 2007 \\
\text { study Questions: } 10,11 \\
\text { 12,13,16 } \\
\text {-Survey Questions in both } \\
\text { studies: } 6,7,8 \\
\text { Interviews } \\
\text { - Interview question } 2 \text { and } \\
\text { open ended survey }\end{array}$ & $\begin{array}{l}\text { Descriptive Data (Survey) } \\
\text { Technology Use and } \\
\text { Frequency of Use } \\
\text { - Frequencies of responses } \\
\text { for question } 10 \text { and } 11 . \\
\frac{\text { Interviews and Document }}{\frac{\text { Analysis }}{\text { Analysis to look for: }}} \\
\text { Impact of Technology } \\
\text {-Analyze interview } \\
\text { question } 2 \text { and open-ended }\end{array}$ \\
\hline
\end{tabular}




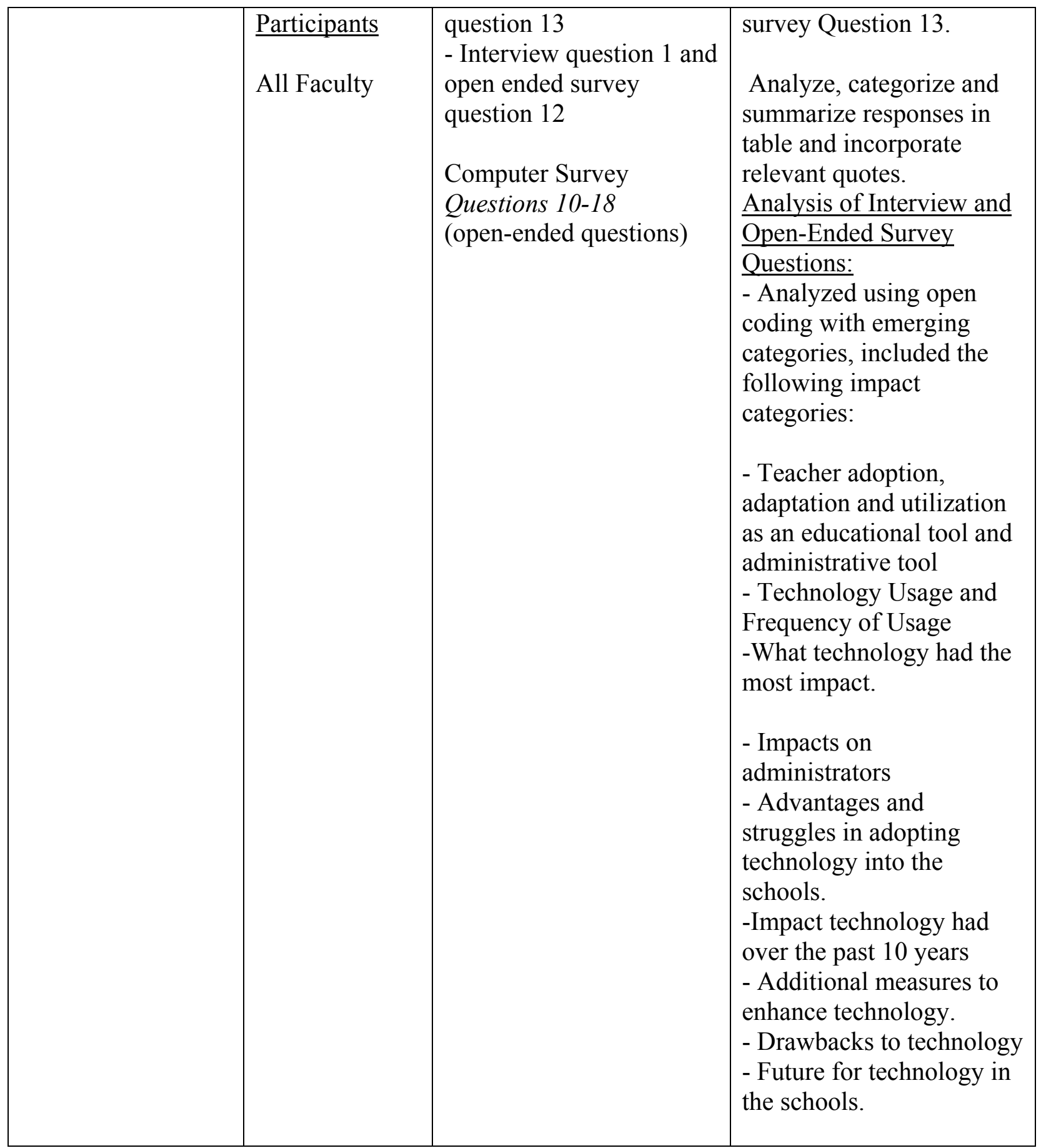

Research Question 1: What are the differences in readiness of the classroom teachers from 1997 and 2007 in their ability to integrate telecommunications within their teaching activities? 


\section{Data Sources for Research Question 1:}

Computer survey: description, collection procedures and analysis method. The faculty were asked to participate in a written instructional technology survey (See Appendix B). After the IRB was approved, the survey was given to the faculty during a faculty senate meeting. The participants were given an opportunity to fill out the survey at their convenience and return it to a box in the school office, anonymously.

The first section of the survey was based on Likert-type questions, where the participant circled a number between 1 and 5 which best corresponds to their situation. The objective of these questions was to get the teacher's self-assessment of the frequency of computer/Internet use, the comfort/anxiety level towards instructional technology, and the amount of training they received. The computer anxiety questions are both in negative and positive format, to allow a backup in the survey to determine if a participant just filled in one answer for all questions without reading the questions.

Additionally, the demographic questions on age range, teaching experience level and area of specialization remained the same as the previous survey. The survey also added the category for number of years teaching at this school, which helped provide some insight on how many teachers were at the school during both surveys.

There were several ways to analyze the data. Data from the original nine questions were analyzed using the same methods as before. Table 2 helps describe the methods of analysis: 
Table 2

Data Analysis for Questions 1-9 of Survey

\begin{tabular}{|c|c|c|}
\hline Variables & $\begin{array}{c}\text { Questions from Survey } \\
\text { Used to Answer the } \\
\text { Question }\end{array}$ & Statistical Test Used \\
\hline $\begin{array}{l}\text { Computer knowledge and. } \\
\text { computer anxiety (computer } \\
\text { level) }\end{array}$ & $\begin{array}{l}\text { Question 1: How would } \\
\text { you rate your knowledge of } \\
\text { computer technologies? } \\
\text { Question 5: How would } \\
\text { you assess your current } \\
\text { level of conflict in using } \\
\text { computers? } \\
\text { (Responses to question } 5 \\
\text { were converted to make a } \\
\text { low number mean low } \\
\text { anxiety and a high number } \\
\text { indicate high anxiety). }\end{array}$ & $\begin{array}{l}\text { Correlation: coefficients } \\
\text { looking if level of computer } \\
\text { knowledge has any } \\
\text { relationship to computer } \\
\text { anxiety. }\end{array}$ \\
\hline $\begin{array}{l}\text { Computer anxiety and in } \\
\text { willingness to adopt } \\
\text { technology. }\end{array}$ & $\begin{array}{l}\text { Question 9: } \\
\text { Reorganized positive and } \\
\text { negative questions so that } \\
\text { they were coded all the } \\
\text { same direction. (1 } \\
\text { indicating high anxiety and } \\
4 \text { being low anxiety) } \\
\text { (Change questions 9b, 9c, } \\
\text { 9d, 9g, 9h, 9l, 9m) } \\
\text { Interview Question } \\
\text { 4/Survey Question } 14\end{array}$ & $\begin{array}{l}\text {-Frequency of responses for } \\
\text { individual questions. } \\
\text {-Mean score for all } \\
\text { questions. } \\
\text { - Compare findings with } \\
\text { responses in open } \\
\text { ended/interview questions } \\
\text { regarding anxiety. }\end{array}$ \\
\hline $\begin{array}{l}\text { Age range vs. computer use } \\
\text { at home } \\
\text { Age range vs. computer use } \\
\text { at school }\end{array}$ & $\begin{array}{l}\text { Demograhic Questions } \\
\text { (Age Range: Codes) } \\
\text { 1: Under 30 } \\
\text { 2: 30-45 } \\
\text { 3: Over 45 } \\
\text { Question 3: How often do } \\
\text { you use computers at } \\
\text { school? } \\
\text { Question } 4 \text { How often do } \\
\text { you use computers at home? }\end{array}$ & $\begin{array}{l}\text { Means table and bar plot: } \\
\text { looking if age has an effect } \\
\text { on computer use at home } \\
\text { and at school. }\end{array}$ \\
\hline
\end{tabular}




\begin{tabular}{|c|c|c|}
\hline $\begin{array}{l}\text { Knowledge of computer } \\
\text { technologies. }\end{array}$ & $\begin{array}{l}\text { Frequency Data/Means } \\
\text { Question 1: How would you } \\
\text { rate you knowledge of } \\
\text { computer technologies. }\end{array}$ & $\begin{array}{l}\text { Histogram: Frequency } \\
\text { charts. } \\
\text { Comparing the means from } \\
\text { the } 1997 \text { and } 2007 \text { study. }\end{array}$ \\
\hline $\begin{array}{l}\text { Amount of computer } \\
\text { training. }\end{array}$ & $\begin{array}{l}\text { Frequency Data/Means } \\
\text { Question 6: How much } \\
\text { training have you received } \\
\text { using the computer as an } \\
\text { instructional tool? }\end{array}$ & $\begin{array}{l}\text { Histogram: Frequency } \\
\text { charts. } \\
\text { Comparing the means from } \\
\text { the } 1997 \text { and } 2007 \text { study. }\end{array}$ \\
\hline
\end{tabular}

To further expand the study, additional questions were evaluated using the data from the 2007 study. Table 3 lists the new questions asked. 
Table 3

Additional Data Analysis for 2007 Survey

\begin{tabular}{|c|c|c|}
\hline Variables & $\begin{array}{l}\text { Questions from Survey } \\
\text { Used to Answer the } \\
\text { Question }\end{array}$ & Statistical Test Used \\
\hline $\begin{array}{l}\text { Area of specialization vs. } \\
\text { computer use at school }\end{array}$ & $\begin{array}{l}\text { From Survey } 2007 \\
\text { Question 3: How often do } \\
\text { you use computers at } \\
\text { school? } \\
\text { Demographics: What is } \\
\text { your area of specialization?: } \\
\text { Coding: } \\
\text { 1. English/Language } \\
\text { Arts } \\
\text { 2. Math } \\
\text { 3. Social Studies } \\
\text { 4. Science } \\
\text { 5. Related Arts/Allied } \\
\text { Arts } \\
\text { 6. Special Education }\end{array}$ & $\begin{array}{l}\text { Correlation: Is there any } \\
\text { relationship between the } \\
\text { area of specialization and } \\
\text { computer use at school? }\end{array}$ \\
\hline $\begin{array}{l}\text { Years of teaching } \\
\text { Experience vs. Amount of } \\
\text { instructional technology } \\
\text { received. }\end{array}$ & $\begin{array}{l}\text { Question 8: How do you } \\
\text { feel about the overall } \\
\text { amount of instructional } \\
\text { technology training you } \\
\text { have received? } \\
\text { Demographic question: } \\
\text { Number of years teaching } \\
\text { Coding: } \\
\text { 1. } 5 \text { years and under } \\
\text { 2. 6-10 years } \\
\text { 3. 11-20 years } \\
\text { 4. over } 20 \text { years }\end{array}$ & Means table and box plot. \\
\hline $\begin{array}{l}\text { How many people had the } \\
\text { opportunity to participate in } \\
\text { the } 1997 \text { survey? }\end{array}$ & $\begin{array}{l}\text { Demographic Question: } \\
\text { How many years have you } \\
\text { been at this school? } \\
\text { Coded: } 1=\text { less than } 10 \\
\text { years }\end{array}$ & Pie chart and percentages \\
\hline
\end{tabular}


After running the analyses and results from the second survey, the two sets of results were compared to determine if any differences in the scores from 1997 and 2007.

Table 4 explains how these results will be analyzed.

Table 4

How 1997 and 2007 Data was Analyzed

\begin{tabular}{|c|c|c|}
\hline Variables & $\begin{array}{c}\text { Questions from Survey } \\
\text { Used to Answer the } \\
\text { question }\end{array}$ & Statistical Test Used \\
\hline $\begin{array}{l}\text { Computer knowledge vs. } \\
\text { computer anxiety (computer } \\
\text { level) }\end{array}$ & $\begin{array}{l}\text { - Compare regression } \\
\text { coefficients from } 1997 \text { and } \\
2007 \text { survey }\end{array}$ & $\begin{array}{l}\text { Compare } r^{2} \text { values from } \\
\text { both data sources. }\end{array}$ \\
\hline $\begin{array}{l}\text { Computer ...anxiety and } \\
\text { willingness to adopt } \\
\text { technology. }\end{array}$ & $\begin{array}{l}\text {-Compare means from } \\
\text { survey question } 9 \text { (1997 and } \\
2007 \text { survey) } \\
\text { - Compare frequency charts }\end{array}$ & $\begin{array}{l}\text { Compare means, mode and } \\
\text { frequency between } 2 \\
\text { samples. } \\
\text { - Compare two groups with } \\
\text { pie charts. }\end{array}$ \\
\hline $\begin{array}{l}\text {-Age range vs. computer } \\
\text { use at home } \\
\text {-Age range vs. computer } \\
\text { use at school }\end{array}$ & $\begin{array}{l}\text { - Compare means from } \\
\text { survey questions } 3 \text { and } 4 \text { vs. } \\
\text { demographics (age) } \\
\text { question. }\end{array}$ & $\begin{array}{l}\text { Compare means and } \\
\text { frequency between } 2 \\
\text { samples. } \\
\text {-Compare two groups with } \\
\text { bar graphs. }\end{array}$ \\
\hline $\begin{array}{l}\text { Knowledge of computer } \\
\text { technologies }\end{array}$ & $\begin{array}{l}\text { - Compare mean scores } \\
\text { from } 1997 \text { and } 2007 \text { survey } \\
\text { (question 1) }\end{array}$ & $\begin{array}{l}\text { Mean score comparison and } \\
\text { histogram graph } \\
\text { comparisons from } 1997 \text { and } \\
2007 \text { surveys. }\end{array}$ \\
\hline $\begin{array}{l}\text { Amount of computer } \\
\text { training }\end{array}$ & $\begin{array}{l}\text { - Compare mean scores } \\
\text { from } 1997 \text { and } 2007 \text { survey } \\
\text { (question 6) }\end{array}$ & $\begin{array}{l}\text { Mean score comparison and } \\
\text { histogram graph } \\
\text { comparisons from } 1997 \text { and } \\
2007 \text { surveys. }\end{array}$ \\
\hline $\begin{array}{l}\text { Knowledge of Internet } \\
\text { applications }\end{array}$ & $\begin{array}{l}\text { - Compare mean scores } \\
\text { from } 1997 \text { and } 2007 \text { survey } \\
\text { (question 2) }\end{array}$ & $\begin{array}{l}\text { Mean score comparison and } \\
\text { histogram graph } \\
\text { comparisons from } 1997 \text { and } \\
2007 \text { survey }\end{array}$ \\
\hline Amount of Internet training & $\begin{array}{l}\text { - Compare mean scores } \\
\text { from } 1997 \text { and } 2007 \text { survey } \\
\text { (question 7) }\end{array}$ & $\begin{array}{l}\text { Mean score comparison and } \\
\text { histogram graph } \\
\text { comparisons from } 1997 \text { and } \\
2007\end{array}$ \\
\hline Anxiety/comfort Level & $\begin{array}{l}\text { - Compare mean scores } \\
\text { from } 1997 \text { and } 2007 \\
\text { (question 5) }\end{array}$ & $\begin{array}{l}\text { - Mean score comparison } \\
\text { from question } 5\end{array}$ \\
\hline
\end{tabular}


The means were compared from the 1997 study and the 2007 study. Graphs were used to visually represent the difference of the results from the two studies.

The second part of the survey was added to the original survey. This section provided an overview of what types of technologies teachers were using and the frequency of use. These questions provided a valuable insight into exactly what is being used in the school. These data were also included in the impact research question (3).

The final section of the survey includes some open-ended questions that provided the teachers a chance to answer questions in more detail. The open-ended questions were analyzed in a similar method to the interview questions (see Table 5 below). The responses were evaluated using emerging themes and impact categories, that were determined from the responses of these questions as well as the interview question responses.

Research Question 2: What are the differences in the technology infrastructure at this school, including the changes in support, physical changes and training in 1997 and $2007 ?$

Data Sources for Research Question 2:

Technology integration survey. Question 6,7,8 relate to technology training and how well the teachers felt they were trained in Internet and computer technologies. These statistical scores were compared with results from the interview and open-ended questions in regards to training. 
Interviews. (Question 2) and Open-Ended Question 13: Which computer technologies do you feel have had the most impact in the school? Responses to these questions were analyzed, categorized, and summarized into categories that are defined by the data.

Responses to these questions gave the participants time to discuss which areas of technology had the most impact. They look beyond just what the teachers are using, but also what the want to use. Possibly some of the technology they selected as high usage was due to requirements of the school. Information like this emerged from the openended questions and interviews.

Interview Question 3: What training has the faculty received? Has it been helpful and meaningful in the integration of computers in the curriculum? And Open-ended question 15: Do you feel that you are adequately prepared/trained to make effective use of computer technology in your classroom?

These questions examined the teachers' feelings about the training they have received. The data were organized by emerging categories that came from the interview and written responses. Responses were categorized and summarized and relevant quotes were taken from the data for the results.

Comparison of the results from the interview/open-ended question data and the quantitative survey question which also dealt with training were conducted to see if any similarities exist.

Document analysis: description, collection procedures and analysis. Document analysis was done by reviewing the infrastructure reports of 1996 and 2007 report. (See Appendix D and E) The same infrastructure collection format was used in both studies, 
to ensure continuity. Comparing these documents helped show the types of change in hardware and connectivity infrastructure that took place over the past decade.

Additional data sources for the document analysis included websites, such as the Digital Divide Report (2006) developed by the West Virginia Department of Education for ABC Middle School as part of the No Child Left Behind act requirements.

Analysis of the documents looked for changes in physical infrastructure the number of computers, types of software, Internet connections, types of accessories, and other technological capabilities from 1996 - 2007.

Research Question 3: What impact has technology had on administration, coordinators, and teachers who are adopting, adapting and utilizing the new technology?

\section{Data Sources for Research Question 3:}

Technology integration survey (Questions 10,11). These questions relate to the usage and frequency of usage of a variety of technology devices and systems that were available in the public schools. Internet applications such as e-mail, instant messaging, web blogs, listservs and searching for resources and content were also included in the questions. These questions were added to supplement the initial infrastructure study, because there are many new technology devices and applications that were not even developed during the first study. The data were analyzed using frequency charts of responses.

Interviews and open-ended survey questions (Questions 12-18). Description, collection procedures, analysis. The interviews were conducted on an individual basis with six participants. Participants included the administrator, the County Technology 
Director, a representative teacher from each grade level fifth through eighth. The teachers that were chosen included teachers from different specialization areas and years of experience. The interviews were conducted as a follow-up after the completion of the survey so that participants to be chosen based on the findings of the survey.

All teachers were asked to respond to similar questions in their open-ended survey. Using this triangulation methodology, the data were richer and more in-depth. Adding the administrator and the County Technology Director (coordinator) allowed for a different view-point and dimension that expanded upon the classroom teachers participating in the survey and the interviews.

After IRB approval, the participants were asked to respond to questions based on pre-selected interview questions (See Appendix C), as well as other similar questions that presented themselves during the interview process. The interviews ran about 15-30 minutes. With permission, the interviews were audiotape-recorded in conjunction with the researcher taking field notes. The field notes log were analyzed and organized with verification of the notes from the tape-recordings of the interviews. Sections of the taperecordings were transcribed during the data processing, as needed.

Interview questions also correlated to similar questions in the open-ended section of the survey (Questions 12-18/Appendix B.) Table 5 shows of how the interview questions align with the survey questions. 
Table 5

Alignment of Interview and Survey Questions

\begin{tabular}{|c|c|}
\hline $\begin{array}{l}\text { Interview Question Number } \\
\quad \text { (see Appendix C) }\end{array}$ & $\begin{array}{l}\text { Survey Question Number } \\
\text { (see Appendix B) }\end{array}$ \\
\hline $\begin{array}{l}\text { 1. In your opinion, what impact has } \\
\text { technology integration had on the school } \\
\text { over the past } 10 \text { years. }\end{array}$ & $\begin{array}{l}\text { 12. Briefly describe the impact that } \\
\text { computer have had on your work as a } \\
\text { teacher. }\end{array}$ \\
\hline $\begin{array}{l}\text { 2. Which computer technologies do you } \\
\text { feel have had the most impact in the } \\
\text { school? }\end{array}$ & $\begin{array}{l}\text { 13. Which computer technologies have } \\
\text { had the most impact in your classroom? }\end{array}$ \\
\hline $\begin{array}{l}\text { 3. Discuss the technology training the } \\
\text { faculty has received. Has it been helpful } \\
\text { and meaningful in the integration of } \\
\text { computers in the curriculum? }\end{array}$ & $\begin{array}{l}\text { 15. Do you feel that you are adequately } \\
\text { prepared/trained to make effective use of } \\
\text { computer technology in your classroom? } \\
\text { Briefly explain. }\end{array}$ \\
\hline $\begin{array}{l}\text { 4. Briefly describe your comfort/anxiety } \\
\text { level in using computer technology as an } \\
\text { instructional tool. }\end{array}$ & $\begin{array}{l}\text { 14. Briefly describe your level of } \\
\text { comfort/anxiety in using computers as an } \\
\text { instructional tool. }\end{array}$ \\
\hline $\begin{array}{l}\text { 5. What do you see in the future for } \\
\text { technology in your school? What measures } \\
\text { could be taken to make computer } \\
\text { technology more effective in the future? }\end{array}$ & $\begin{array}{l}\text { 17. What additional measures could be } \\
\text { taken to enable you to make more effective } \\
\text { use of computer technology? (This might } \\
\text { include additional training, computer } \\
\text { hardware or software enhancements etc.) }\end{array}$ \\
\hline $\begin{array}{l}\text { 6. Is there anything else you would like to } \\
\text { discuss in regard to technology in the } \\
\text { schools? }\end{array}$ & $\begin{array}{l}18 \text {. Please list any additional comments } \\
\text { below. }\end{array}$ \\
\hline
\end{tabular}

Field notes and open-ended survey responses were analyzed using open-coding which allows for emerging categories. In the emergent design the researcher "avoids getting locked into rigid designs that eliminate responsiveness and pursues new paths of discovery as they emerge" (Patton, 2002, p. 40). The emerging themes and impact areas were then further organized and synthesized to use the data to help answer the research questions. 
After organizing the data into relevant categories, the data were compared to the statistical findings. This helped form conclusions and helped explain the reasoning behind the statistical findings. By using the mixed method design, all of the data was meshed together to form the results section of the study.

The interview field notes, tape-recordings, and survey responses were not labeled by the respondent's name. Any direct quotes used in the dissertation are identified by only job classification (teacher, principal (administrator), County Technology Director) to protect confidentiality and privacy of the school and the participants. Any notes, surveys or tapes will be discarded upon completing this study.

\section{Validity and Reliability}

The survey used in the research was modified from the survey given in 1997. Both surveys asked questions 1-9, so exact comparisons could be made with those questions. It would be assumed the reliability and validity would be expected to be comparable. Questions 10 and 11 were added to the new survey. They were modified using ideas in the survey from the Ropp (1999) article published in the Journal of Research on Computing in Education. The West Virginia Department of Education also published Digital Divide Reports (2006), which were used to help in the development of these infrastructure questions on my survey as well. The researcher's background, experience and knowledge as a technology teacher further validated the types of infrastructure questions to be asked in the survey. To additionally test for validity of the instrument, people who were competent in computers and teachers were asked to evaluate the survey. 
To test for reliability, the pilot test helped determine consistency of results. The instrument itself helped show reliability by having some questions that were similar in nature. Validity was also gained by having the positive/negative format of similar questions to see if the participant answered similarly.

\section{Limitations of the Study}

This study looked at a case study to assess how participants' attitudes towards computers, computer implementation, and infrastructure differs from 1997 and 2007. The study looked at just one school, so it may not be generalizable to other school settings that may have had different situations. But, for this population the information was meaningful for their evaluations and future implementations and may be informative regarding technology integration efforts in other middle schools.

This research also relied on teachers' own perspectives towards using computers and their training and attitudes. The researcher had to trust their self reports. The scope of this research did not include observations of the teachers in the classroom using the technology, or following the teachers through the process of technology implementation over the past 10 years. Therefore, this was not considered an all- encompassing look at the path that the school has taken over the past 10 years in terms of instructional technology use. 


\section{Chapter IV}

\section{Results and Findings}

\section{Research Strategy Overview}

This chapter addresses the findings from the data collection to help answer the three research questions. Results from the survey were analyzed using statistical methodologies as described in the methodology section Chapter 3. Tables and graphs were included from the SPSS software output that was used to analyze the statistics.

The interviews were analyzed using the field notes and filling in with the tape recordings. Relevant elements from the interviews and open-ended questions were organized into categories. The data were further organized and synthesized into emerging themes. Charts showing the themes found in the responses were developed to help explain the findings further. Quotes and statements from the participants were included to help give the data more depth and understanding.

The document analysis was conducted from the infrastructure study of 1996 (Appendix D) and the 2007 version (Appendix E). The two studies were compared and a chart of significant findings was developed.

This chapter is divided into the three sections (Research Questions). The data, tables, graphs, quotes, and explanation of the results is found under each research question.

The data and findings used to address research question 1 are divided into two parts. The first part is the results from the 2007 survey that helps address the teachers' readiness to use and integrate technology. The results for the 1997 survey are found in Appendix A. 
The second section of data for research question 1 compare the results from the 2007 and 1997 study. Using the questions that were asked in both surveys, the results were compared using mean, frequency and correlation score comparisons.

\section{Results for Research Question 1}

Research Question 1: What are the differences in readiness of the classroom teachers from 1997 and 2007 in their ability to integrate telecommunications within their teaching activities?

Results from 2007

The survey questions were used to address this research question.

Is there any relationship between computer knowledge and computer anxiety? A correlation analysis looked for any correlations with these two factors (see Table 6).

Question 1: "How would you rate your knowledge of computer technologies" and

Question 5: "How would you assess your current level of conflict using computers, computer anxiety and willingness to adopt the technology?" 
Table 6

Correlation of Question 1 and Question 5 (Computer Knowledge and Anxiety)

\begin{tabular}{|l|l|r|r|}
\hline & & \multicolumn{1}{|c|}{$\begin{array}{c}\text { Computer } \\
\text { Knowledge }\end{array}$} & \multicolumn{1}{c|}{$\begin{array}{c}\text { Computer } \\
\text { Anxiety }\end{array}$} \\
\hline Computer Knowledge & $\begin{array}{l}\text { Pearson } \\
\text { Correlation }\end{array}$ & 1 & $-.682^{* *}$ \\
\cline { 2 - 4 } & Sig. (2-tailed) & & .000 \\
\hline Computer Anxiety & $\begin{array}{l}\text { Pearson } \\
\text { Correlation }\end{array}$ & $-.682^{* *}$ & 1 \\
\cline { 2 - 4 } & Sig. (2-tailed) & .000 & \\
\hline
\end{tabular}

These variables were analyzed using a Pearson bivariant correlation to assess if there is any correlation between computer knowledge and computer anxiety. The results found that there was a negative slope correlation $(r=-.689)$ which indicates that there is some correlation between the two factors. These results mean that more training correlates to a lower anxiety level. The closer the number gets to $1.0 /-1.0$, the more correlation the two factors have.

During one of the interviews, a teacher helped to explain this correlation; "Basically, a lot of people who aren't computer savvy have fear. When the teachers are introduced to a new program (like Gradequick) they stress out at first. When they finally have time to learn, play and take it to their classroom and use it - then they are finally OK with it now." This quote helps to show that the more training/the less anxiety the teachers have about using the technology.

Computer attitude/anxiety: Question 9. Question 9 has thirteen parts which asked attitudinal/anxiety questions regarding using computer, the Internet and technology in the classroom. The questions were designed to have show positive and negative statements 
towards technology to help further validate the questions. The questions were labeled with letters (A-M) for the analysis section.

The data were analyzed in two ways. Each question was analyzed in a frequency distribution chart using descriptive statistics organized in a histogram/bar graph chart. The frequency table shows the frequency (number of people) and percent of participants that selected that response. These tables show the actual response of the participants. The bar graph helps to give a visual representation of the data. This analysis is shown below for the 13 questions:

Guide to reading the frequency table. For each survey question the participants circled a number which corresponded to their feeling about the answer. The codes for these questions are as follow:

$\begin{array}{cc}1 & \begin{array}{c}\text { Strongly Agree } \\ \text { Disagree } \\ \text { Agree }\end{array} \\ 4 & \text { Strongly Agree } \\ \text { Other } & \text { If a person selected } 2 \\ & \text { responses, like } 2 \text { and } \\ & 3, \text { the numbers } \\ & \text { would be calculated } \\ & \text { as a } 2.5\end{array}$

Note that these categories and numbers can be seen in the frequency charts and graphs. When looking at means for the analyses, refer to the chart as to what category is closest to the mean number for that question. If the mean for the question was at 2.0 or below, the group would have disagreed with that question. If the mean was above 2.0, the group (as a whole) would have agreed to the question. The further away the mean was from the middle (2.0), the stronger feeling was towards that question. (A 3.8 would 
be a mean with a high level of agreement and a 1.2 would be a mean with very low level of agreement).

Table 7

Question 9 A: Frequency (Computer Confidence)

\begin{tabular}{|c|c|c|c|c|c|}
\hline & & Frequency & Percent & Valid Percent & Cumulative Percent \\
\hline & 1 Strongly Disagree & 0 & 0 & 0 & 0 \\
\hline \multirow[t]{4}{*}{ Valid } & 2 Disagree & 4 & 11.1 & 11.1 & 11.1 \\
\hline & 2.5 (Between 2/3) & 1 & 2.8 & 2.8 & 13.9 \\
\hline & 3 Agree & 20 & 55.6 & 55.6 & 69.4 \\
\hline & 4 Strongly Agree & 11 & 30.6 & 30.6 & 100.0 \\
\hline Mean & & & 3.18 & & \\
\hline
\end{tabular}

Figure 1: Frequency graph of responses for question 9 A (Computer Confidence).

Histogram

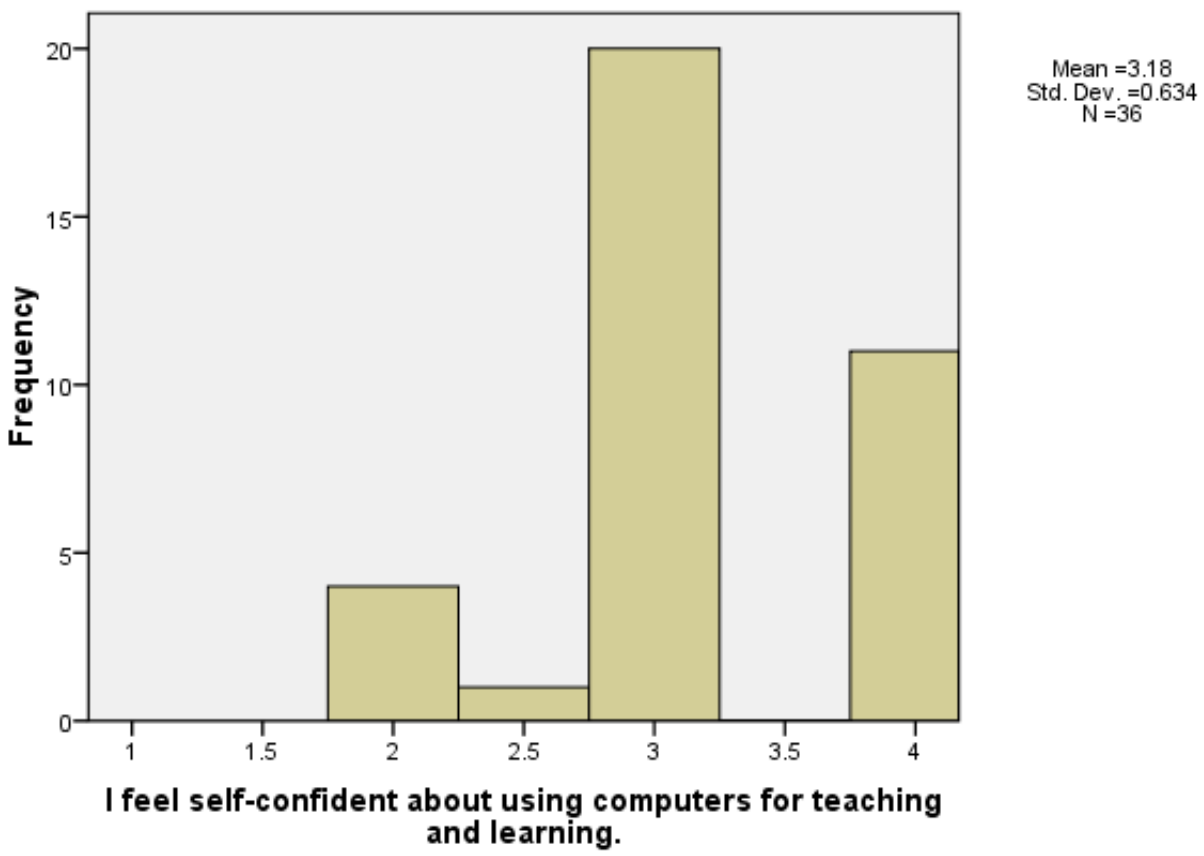


When asking the teachers about their self-confidence about using computers, a majority of the participants (86.2\%) said they agree to this statement. The mean response for this question is 3.18. It is also important to note that no one answered "strongly disagree."(see Table 7 and Figure1). 
Table 8

Question 9 B: Frequency (Too Much Emphasis on Computers)

\begin{tabular}{|l|l|r|r|r|r|}
\hline \multicolumn{2}{|c|}{ I feel too much emphasis is being placed on the use of computers for teaching and learning. } \\
\hline \multirow{4}{*}{ Valid } & Frequency & Percent & Valid Percent & $\begin{array}{c}\text { Cumulative } \\
\text { Percent }\end{array}$ \\
\cline { 2 - 7 } & 1 Strongly Disagree & 4 & 11.1 & 11.1 & 11.1 \\
\cline { 2 - 7 } & 2 Disagree & 13 & 36.1 & 36.1 & 47.2 \\
\cline { 2 - 7 } & 3 Agree & 13 & 36.1 & 36.1 & 83.3 \\
\cline { 2 - 7 } & 4 Strongly Agree & 6 & 16.7 & 16.7 & 100.0 \\
\hline
\end{tabular}

\begin{tabular}{|l|r|} 
Mean & 2.58 \\
\hline
\end{tabular}

Figure 2: Frequency graph of responses for question 9 B (Too much emphasis on computers).

\section{I feel too much emphasis is being placed on the use of computers for teaching and learning.}

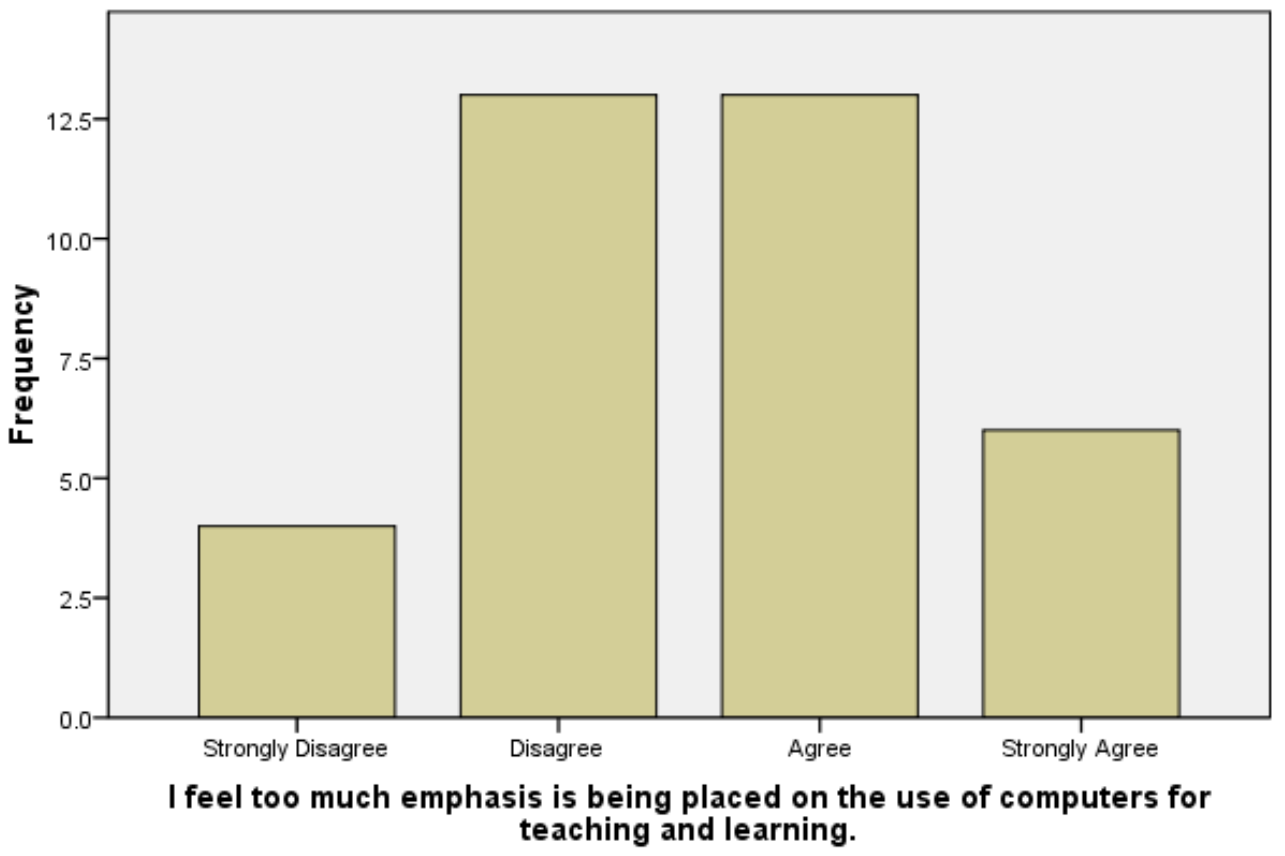

This question shows that few teachers have strong opinions towards the use of computers. Four participants (11.1\% strongly disagree) and 6 participants (16.7\%) 
strongly agree to this question. The rest of the respondents were equally divided in agreeing and disagreeing with this statement. There were 13 people agreeing $(36.7 \%)$ and 13 people disagreeing (36.7\%). The mean for this question is 2.58 . This question is negatively worded, meaning the lower mean indicated a lower anxiety level for the population (see Table 8 and Figure 2).

Table 9

Question 9 C: Frequency (Concerned about Time of Use Computers)

\begin{tabular}{|c|c|c|c|c|c|}
\hline \multicolumn{6}{|c|}{$\begin{array}{l}\text { I am concerned about having enough time to learn about computers so that I can use them } \\
\text { effectively. }\end{array}$} \\
\hline & & Frequency & Percent & Valid Percent & $\begin{array}{c}\text { Cumulative } \\
\text { Percent }\end{array}$ \\
\hline \multirow[t]{4}{*}{ Valid } & 1 Strongly Disagree & 4 & 11.1 & 11.1 & 11.1 \\
\hline & 2 Disagree & 6 & 16.7 & 16.7 & 27.8 \\
\hline & 3 Agree & 16 & 44.4 & 44.4 & 72.2 \\
\hline & 4 Strongly Agree & 10 & 27.8 & 27.8 & 100.0 \\
\hline
\end{tabular}

\begin{tabular}{|l|r|}
\hline Mean & 2.89 \\
\hline
\end{tabular}


Figure 3: Frequency graph of responses for question $9 \mathrm{C}$ (Concerned about time to use computers).

\section{I am concerned about having enough time to learn about computers so that I can use them effectively.}

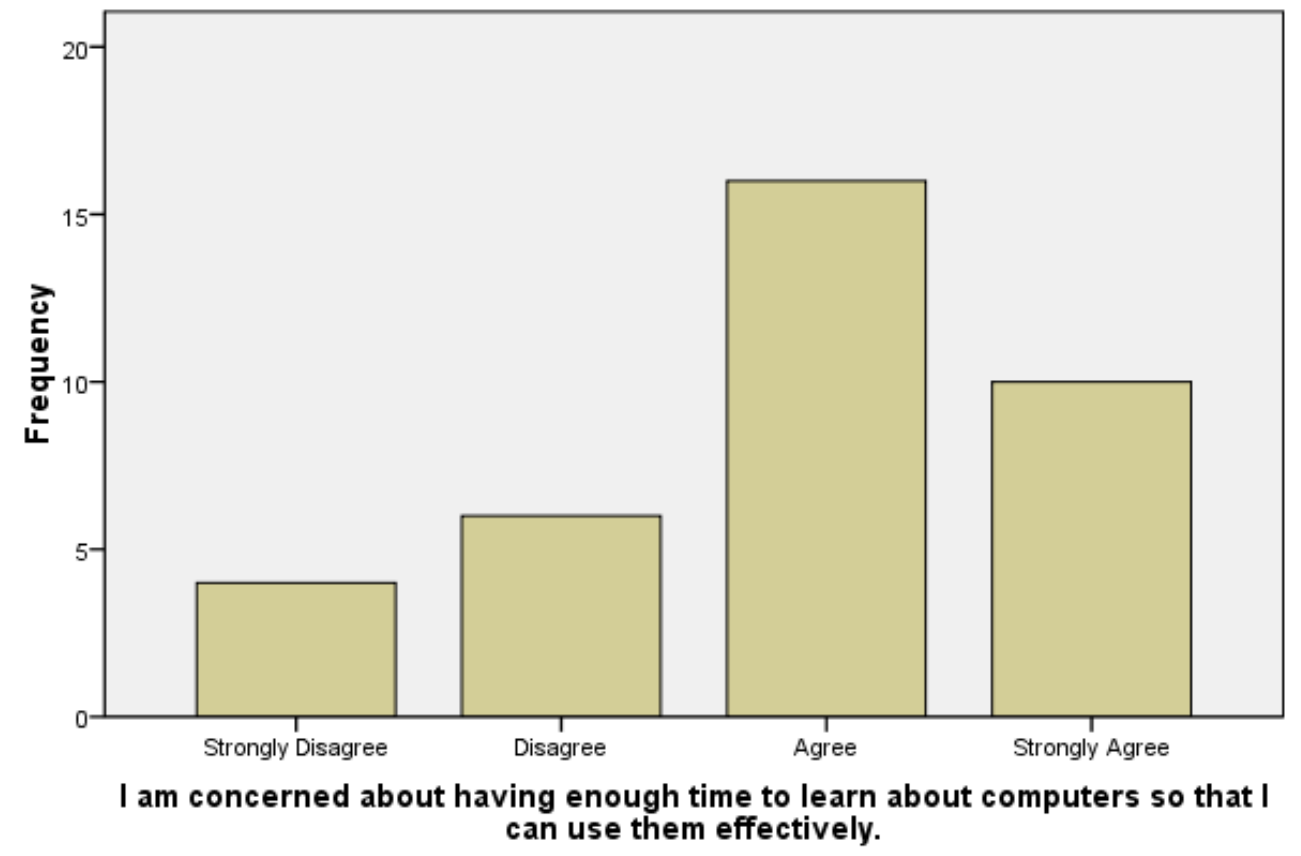

This question shows that the majority $(71.4 \%)$ of the participants responded "agree" or "strongly agree" to this question. There were 4 people who strongly disagreed with this question. The mean for this question was 2.89 (see Table 9 and Figure 3). Initially, this question was considered negatively worded, with the assumption that people who find the technology important enough will find the time. Yet, in further analysis of this question and other data in this study, that may have been a false assumption. One teacher said regarding this statement "I want to learn the technology but do not have the time given the busy schedule to do so... we need time specially 
scheduled to learn about technology". Many other teachers responded with similar answers (as seen below in the analysis about training under research question 2).

Initial consideration of this as a negatively worded question may not be held true for all cases. Thus, it should be considered that at least some of the teachers saying "agree or strongly agree" do so not because they have anxiety about computers, but because they really just don't have the time to learn and would like to if they could.

Table 10

Question 9 D: Frequency (Not Interested in Learning about Computers)

\begin{tabular}{|c|c|c|c|c|c|}
\hline \multicolumn{6}{|c|}{ At this time, I am not interested in learning about computers. } \\
\hline & & Frequency & Percent & Valid Percent & $\begin{array}{c}\text { Cumulative } \\
\text { Percent } \\
\end{array}$ \\
\hline \multirow[t]{5}{*}{ Valid } & 1 Strongly Disagree & 14 & 38.9 & 38.9 & 38.9 \\
\hline & 2 Disagree & 14 & 38.9 & 38.9 & 77.8 \\
\hline & 2.5 (Between 2/3) & 1 & 2.8 & 2.8 & 80.6 \\
\hline & 3 Agree & 4 & 11.1 & 11.1 & 91.7 \\
\hline & 4 Strongly Agree & 3 & 8.3 & 8.3 & 100.0 \\
\hline Mean & & & & & \\
\hline
\end{tabular}


Figure 4: Frequency graph of responses for question $9 \mathrm{D}$ (Not interested in learning about computers).

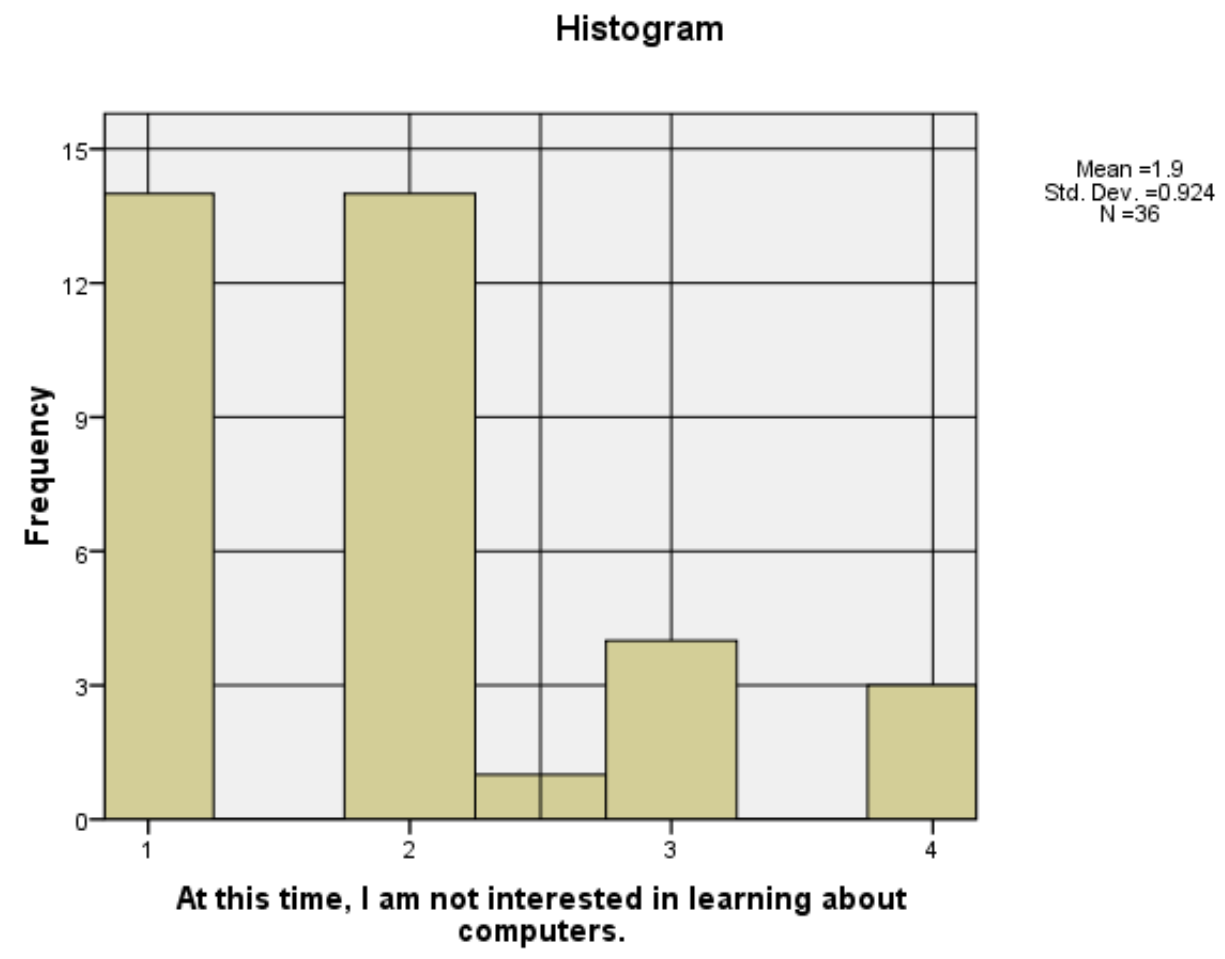

A majority of the participant (77.8\%) disagreed or strongly disagreed with this question. Only $8.3 \%$ strongly agreed. The mean for this question was a low 1.9 , since this question was negatively worded; a low mean indicates a lower anxiety/attitude level. Since the teachers were in disagreement with this statement, it shows that the teachers are interested in learning about computers at this time (see Table 10 and Figure 4). 
Technology Integration 55

Table 11

Question 9 E: Frequency (Learning Computers makes me Effective Teacher)

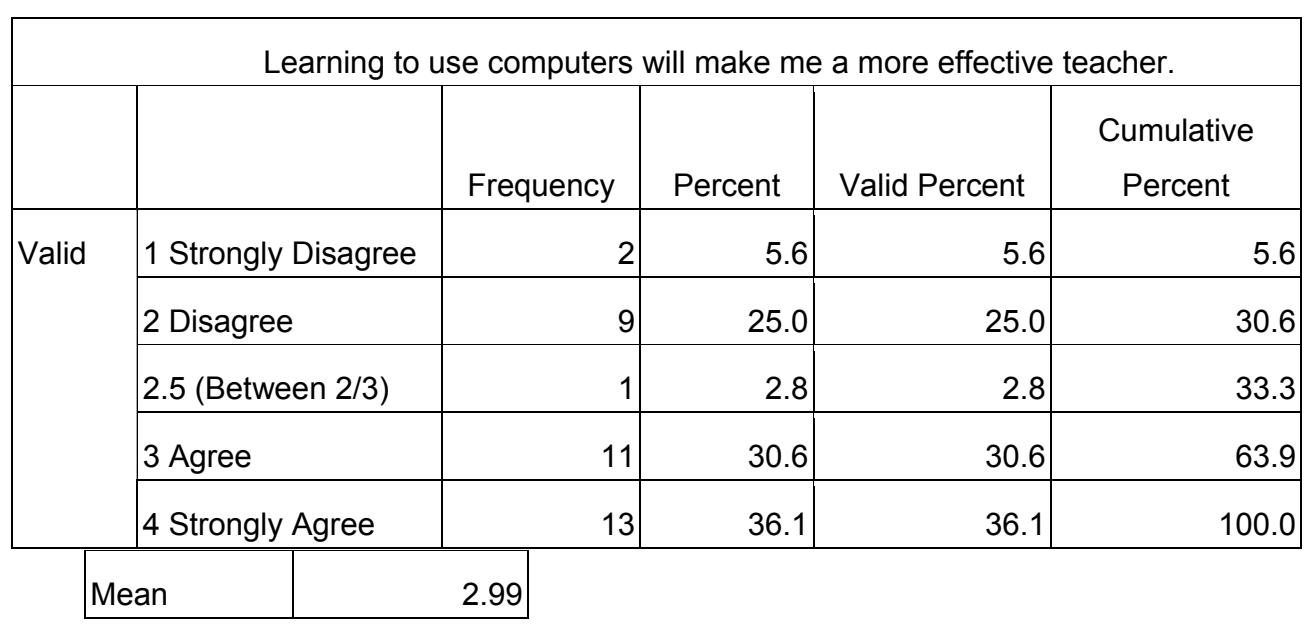


Figure 5: Frequency graph for responses to question 9 E (Learning computers makes me an effective teacher.

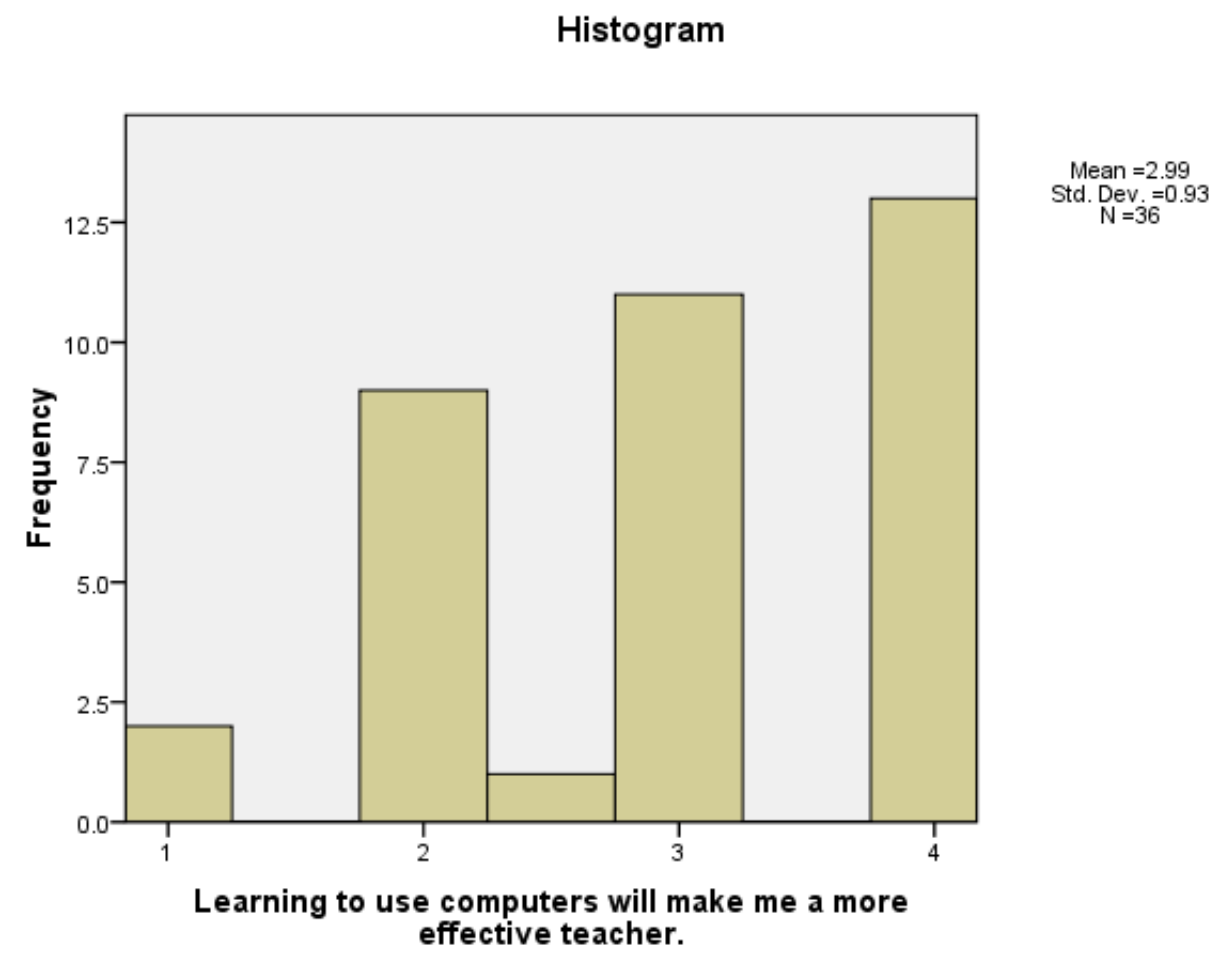

The majority of teachers (66.7\%) selected "agree" or "strongly agree" with the "strongly agree" as the most frequent response (13 people). The strongly disagree category had 2 responses. The mean for this question was 2.99 showing that a majority of the teachers feel learning to use computers will make them more effective (see Table 11 and Figure 5). 


\section{Table 12}

Question 9 F: Frequency (Computer Literacy should be Learning Outcome)

\begin{tabular}{|l|l|r|r|r|r|}
\hline \multicolumn{7}{|c|}{ Computer literacy should be a learning outcome of our school system. } \\
\hline \multirow{5}{*}{ Valid } & & & & & \multicolumn{2}{c|}{$\begin{array}{c}\text { Cumulative } \\
\text { Percent }\end{array}$} \\
\cline { 2 - 7 } & 1 Strongly Disagree & 2 & 5.6 & 5.6 & 5.6 \\
\cline { 2 - 7 } & 2 Disagree & 3 & 8.3 & 8.3 & 13.9 \\
\cline { 2 - 7 } & 3 Agree & 16 & 44.4 & 44.4 & 58.3 \\
\cline { 2 - 7 } & 4 Strongly Agree & 15 & 41.7 & 41.7 & 100.0 \\
\hline
\end{tabular}

\begin{tabular}{|l|r|}
\hline Mean & 3.22 \\
\hline
\end{tabular}


Figure 6: Frequency graph of responses for question $9 \mathrm{~F}$ (Computer literacy should be a learning outcome).

\section{Computer literacy should be a learning outcome of our school system.}

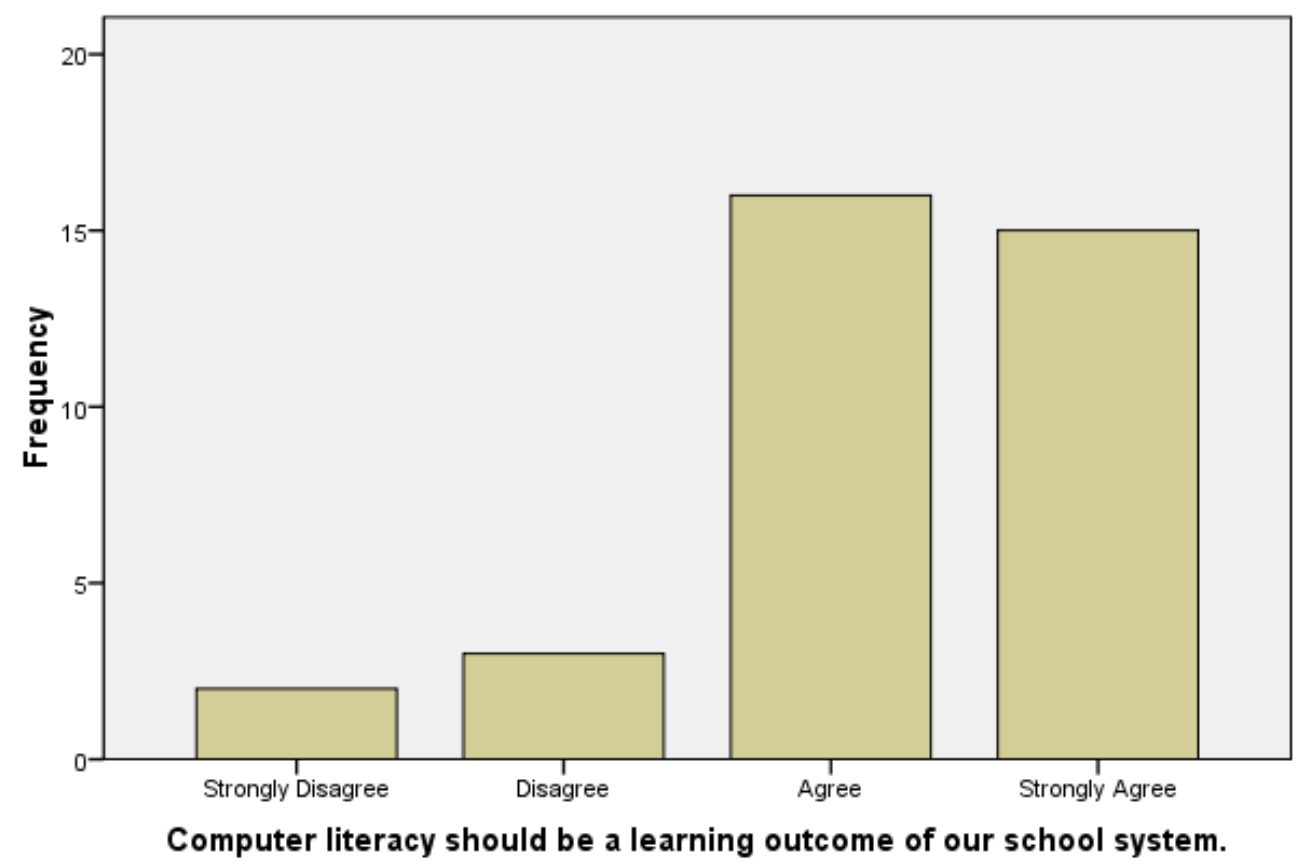

Of the 35 teachers, $30(86.1 \%)$ agreed or strongly agreed that technology should be learning outcome for the school system. For technology to be successfully adopted, it is important to note that the majority of the teachers feel that it should be adopted. The mean for this question is 3.22 , it shows that a majority of the teacher value the importance of technology, despite their level of anxiety towards the technology (see Table 12 and Figure 6). 
Table 13

Question 9 G: Frequency (Overwhelmed about Learning and Using Computers)

\begin{tabular}{|l|l|r|r|r|r|}
\hline \multicolumn{2}{|c|}{ I am overwhelmed about having to learn and use computers for teaching and learning. } \\
\hline \multirow{4}{*}{ Valid } & & Frequency & Percent & Valid Percent & $\begin{array}{c}\text { Cumulative } \\
\text { Percent }\end{array}$ \\
\cline { 2 - 7 } & 1 Strongly Disagree & 8 & 22.2 & 22.2 & 22.2 \\
\cline { 2 - 7 } & 2 Disagree & 17 & 47.2 & 47.2 & 69.4 \\
\cline { 2 - 7 } & 3 Agree & 8 & 22.2 & 22.2 & 91.7 \\
\cline { 2 - 7 } & 4 Strongly Agree & 3 & 8.3 & 8.3 & 100.0 \\
\hline \multirow{2}{*}{ Mean } & 2.17 & & & & \\
\hline
\end{tabular}

Figure 7: Frequency graph of responses for question $9 \mathrm{G}$ (overwhelmed about learning and using computers).

\section{I am overwhelmed about having to learn and use computers for teaching and learning.}

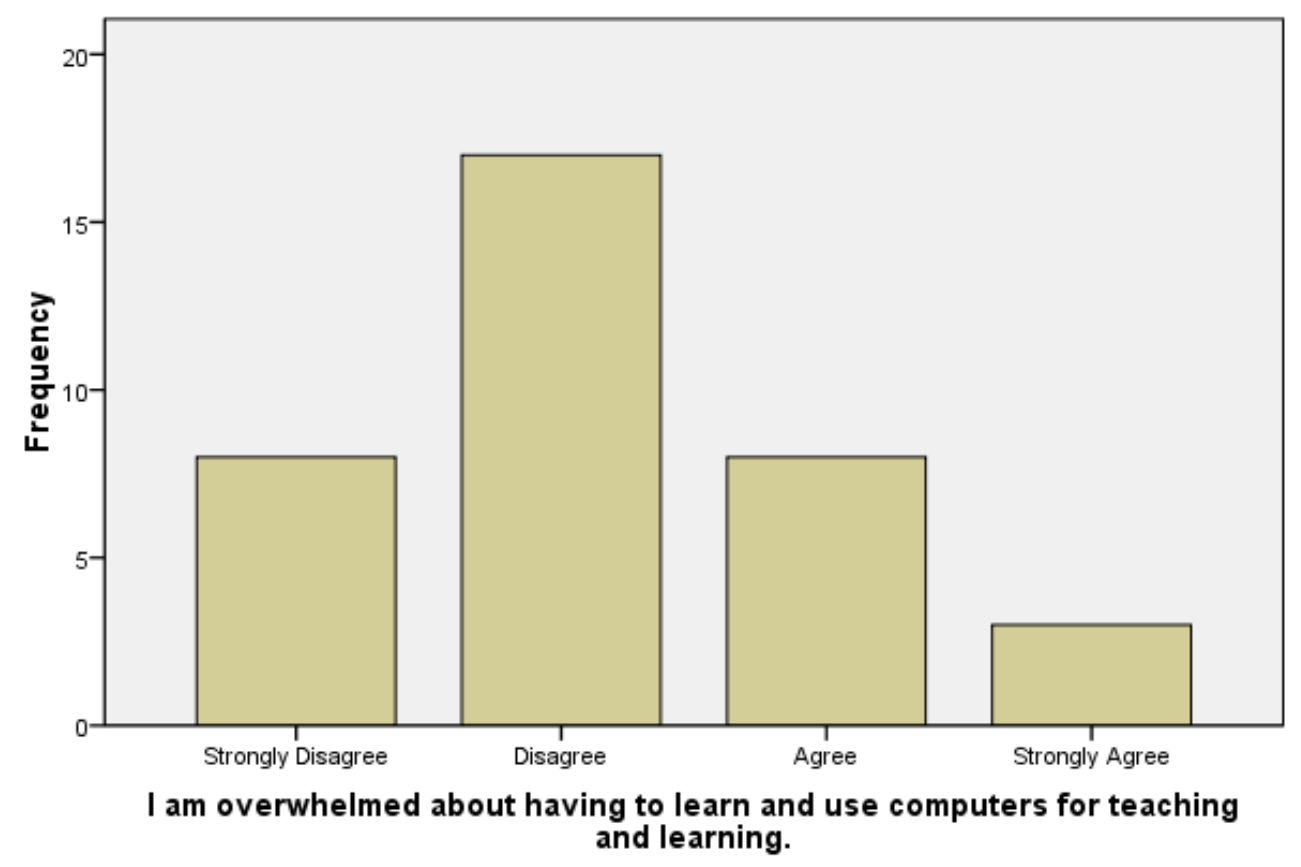

In this question the teachers were asked if they felt overwhelmed about computers. Having a large percent of teachers strongly disagreeing (22.2\%) or disagreeing $(47.2 \%)$ to this question show that they don't feel overwhelmed about the 
technology. The lower mean in this question (2.17) reveals a lessened anxiety/attitude, since it is a negatively worded question (see Table 13 and Figure 7). 
Table 14

Question 9 H: Frequency (Computer Use to Computer Lab)

\begin{tabular}{|l|l|r|r|r|r|}
\hline \multicolumn{2}{|c|}{ Computer use should be limited to a computer lab instead of being integrated into the } \\
classroom curriculum. & \multicolumn{2}{c|}{$\begin{array}{c}\text { Cumulative } \\
\text { Percent }\end{array}$} \\
\hline \multirow{4}{*}{ Valid } & Frequency & Percent & Valid Percent & 30.6 \\
\cline { 2 - 7 } & 1 Strongly Disagree & 11 & 30.6 & 30.6 & 77.8 \\
\cline { 2 - 7 } & 2 Disagree & 17 & 47.2 & 47.2 & 91.7 \\
\cline { 2 - 7 } & 3 Agree & 5 & 13.9 & 13.9 & 100.0 \\
\cline { 2 - 7 } & 4 Strongly Agree & 3 & 8.3 & 8.3 & \\
\hline \multirow{2}{*}{ Mean } & 2.00 & & & & \\
\end{tabular}

Figure 8: Frequency graph of responses for question $9 \mathrm{H}$ (Computer use limited to computer lab).

\section{Computer use should be limited to a computer lab instead of being integrated into the classroom curriculum.}

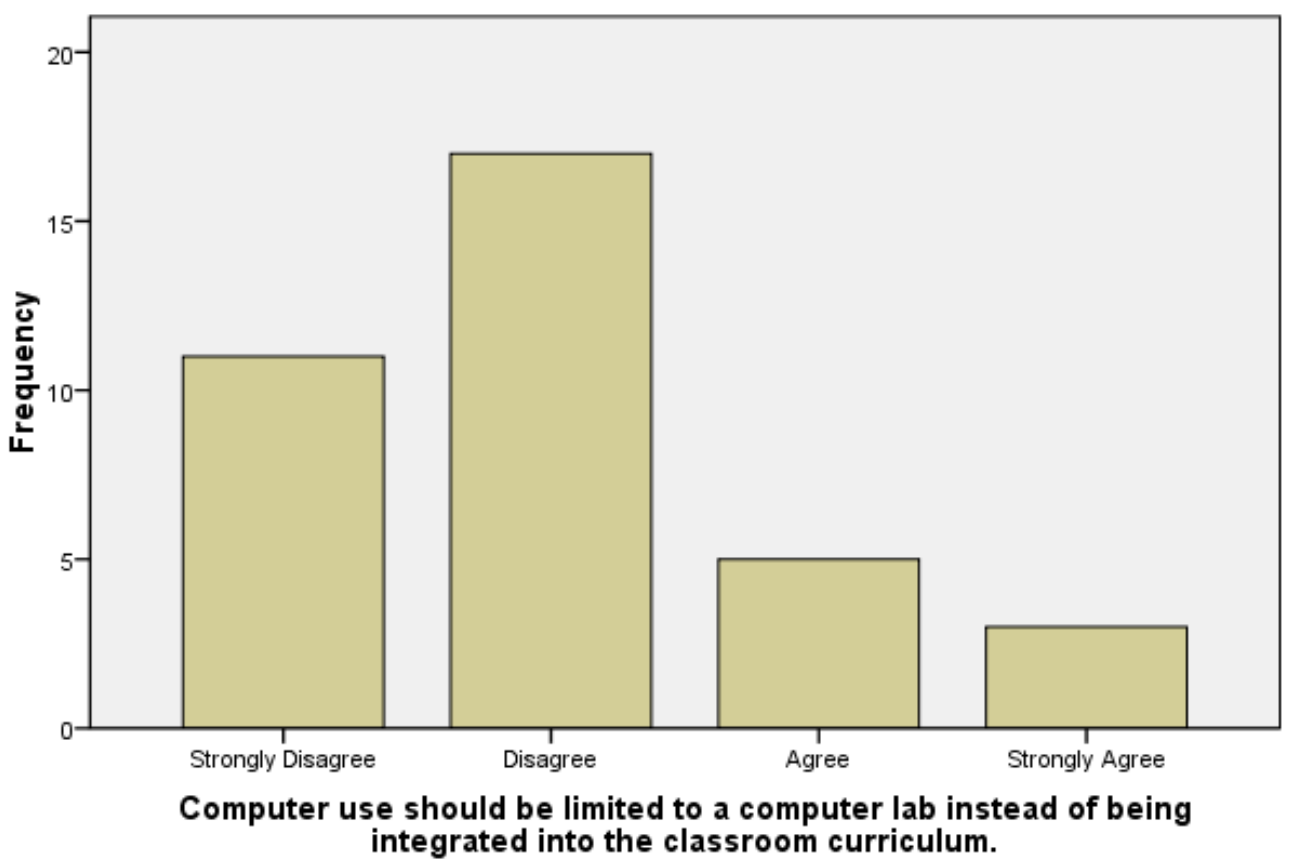


This question helps to look at the idea of where the computers should be utilized. Teachers at this school strongly disagree or disagree $(77.8 \%)$ as a majority that computer use should only be limited to the computer lab setting. Only 3 participants strongly agreed to this response. The mean for this question is 2.0 , which is right in the middle. This question would be considered negatively worded (see Table 14 and Figure 8). The assumption is that teachers who solely want computer use in the lab may not feel as comfortable integrating the technology in their daily lessons.

Table 15

Question 9 I: Frequency (All Classrooms Equipped with Computers)

\begin{tabular}{|l|l|r|r|r|r|}
\hline \multicolumn{7}{|c|}{ All classrooms should be equipped with computers. } \\
\hline \multirow{5}{*}{ Valid } & Frequency & Percent & Valid Percent & $\begin{array}{c}\text { Cumulative } \\
\text { Percent }\end{array}$ \\
\cline { 2 - 7 } & 1 Strongly Disagree & 2 & 5.6 & 5.6 & 5.6 \\
\cline { 2 - 7 } & 2 Disagree & 3 & 8.3 & 8.3 & 13.9 \\
\cline { 2 - 7 } & 3 Agree & 13 & 36.1 & 36.1 & 50.0 \\
\cline { 2 - 7 } & 4 Strongly Agree & 18 & 50.0 & 50.0 & 100.0 \\
\hline
\end{tabular}

\begin{tabular}{|l|r|}
\hline Mean & 3.31 \\
\hline
\end{tabular}


Figure 9: Frequency graph for question 9 I (All classrooms equipped with computers).

\section{All classrooms should be equipped with computers.}

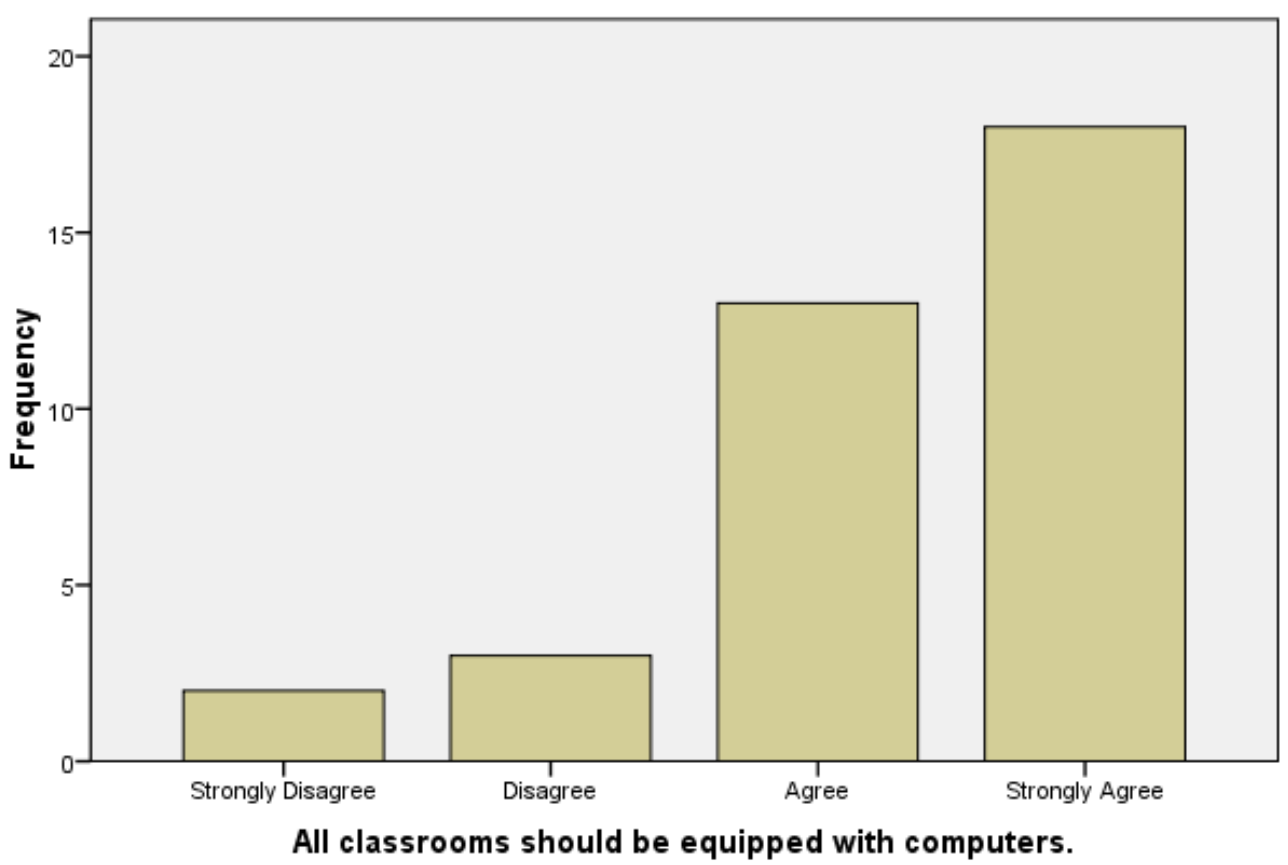

This question is the opposite of the previous question of having computer use

limited only to the computer lab setting. The results for question closely fall into a similar pattern as the previous question. An overwhelming majority $(86.1 \%)$ "agreed" or "strongly agreed" to this question, meaning that they believe that all classrooms should be equipped with computers. It is also important to note that a majority of the responses $(50 \%)$ selected "strongly agree" to this response. The mean was also a high 3.31(see Table 15 and Figure 9). 
Table 16

Question 9 J: Frequency (All Students Should Use Internet)

All students should use the Internet as part of the curriculum for instruction, learning and

\begin{tabular}{|c|c|c|c|c|c|}
\hline & & Frequency & Percent & Valid Percent & $\begin{array}{c}\text { Cumulative } \\
\text { Percent }\end{array}$ \\
\hline \multirow[t]{4}{*}{ Valid } & 1 Strongly Disagree & 2 & 5.6 & 5.6 & 5.6 \\
\hline & 2 Disagree & 9 & 25.0 & 25.0 & 30.6 \\
\hline & 3 Agree & 15 & 41.7 & 41.7 & 72.2 \\
\hline & 4 Strongly Agree & 10 & 27.8 & 27.8 & 100.0 \\
\hline Mean & & & & & \\
\hline
\end{tabular}

Figure 10: Frequency graph of responses for question $9 \mathrm{~J}$ (All students should use Internet).

\section{All students should use the Internet as part of the curriculum for instruction, learning and research.}

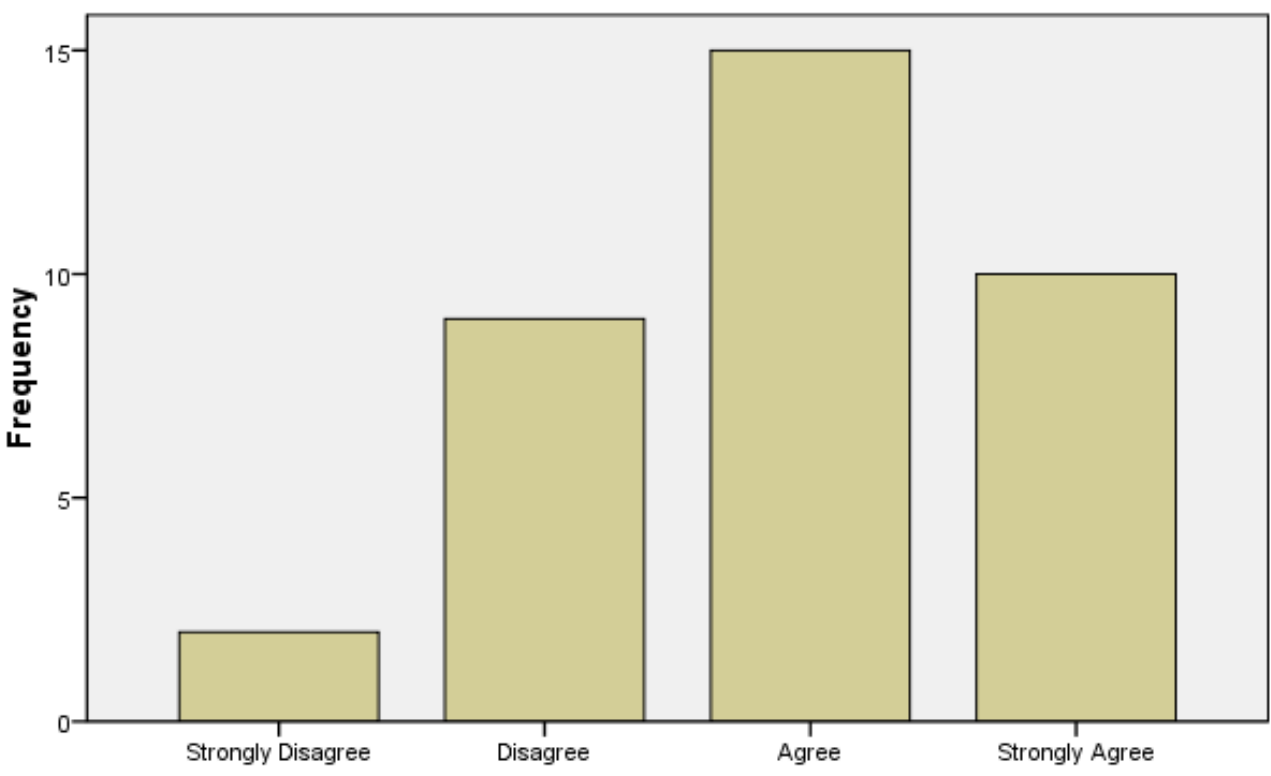

All students should use the Internet as part of the curriculum for instruction, learning and research. 
The idea of students using the Internet evoked a mixed response from the teachers. While a majority of teachers $69.5 \%$ agreed or strongly agreed, still a $25 \%$ disagreed and 5.6\% strongly disagreed. The mean for this question is 2.92 (see Table 16 and Figure 10). This data suggests that while many teachers can see the benefits of using the Internet, there was also some hesitation in allowing the students to use the Internet. There are several possibilities for the hesitation, including Internet safety and security issues, inappropriate materials that can be found on the Internet, and the ability to find quality materials among the less accurate resources. 
Table 17

Question 9 K: Frequency (All Teachers Should Use Internet)

All teachers should use the Internet for communications, instruction development, and

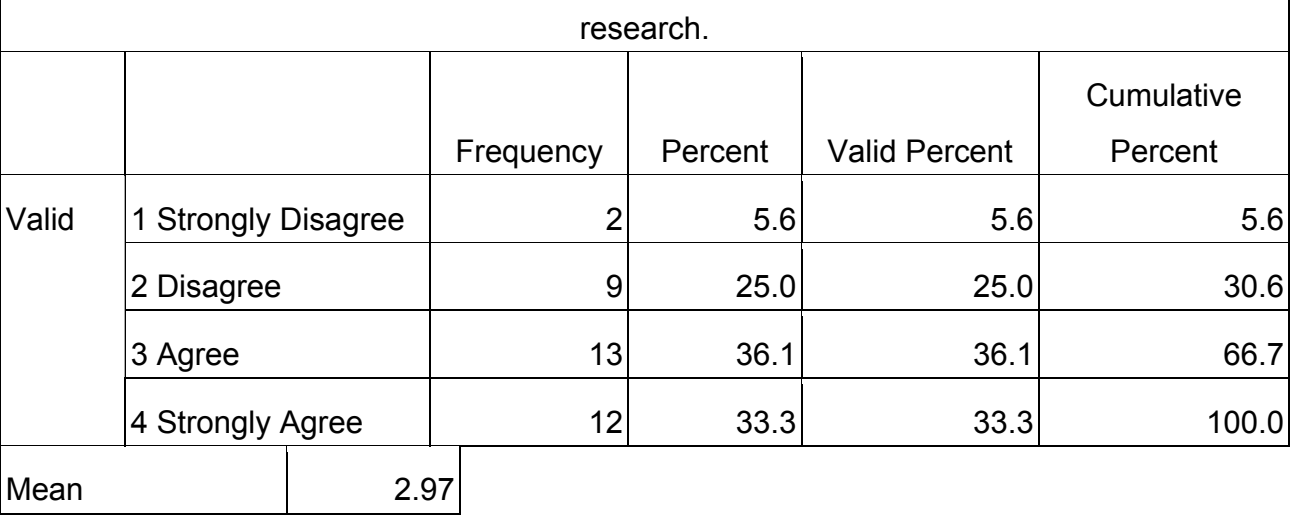

Figure 11: Frequency graph of responses for question $9 \mathrm{~K}$ (All teachers should use Internet).

\section{All teachers should use the Internet for communications, instruction} development, and research.

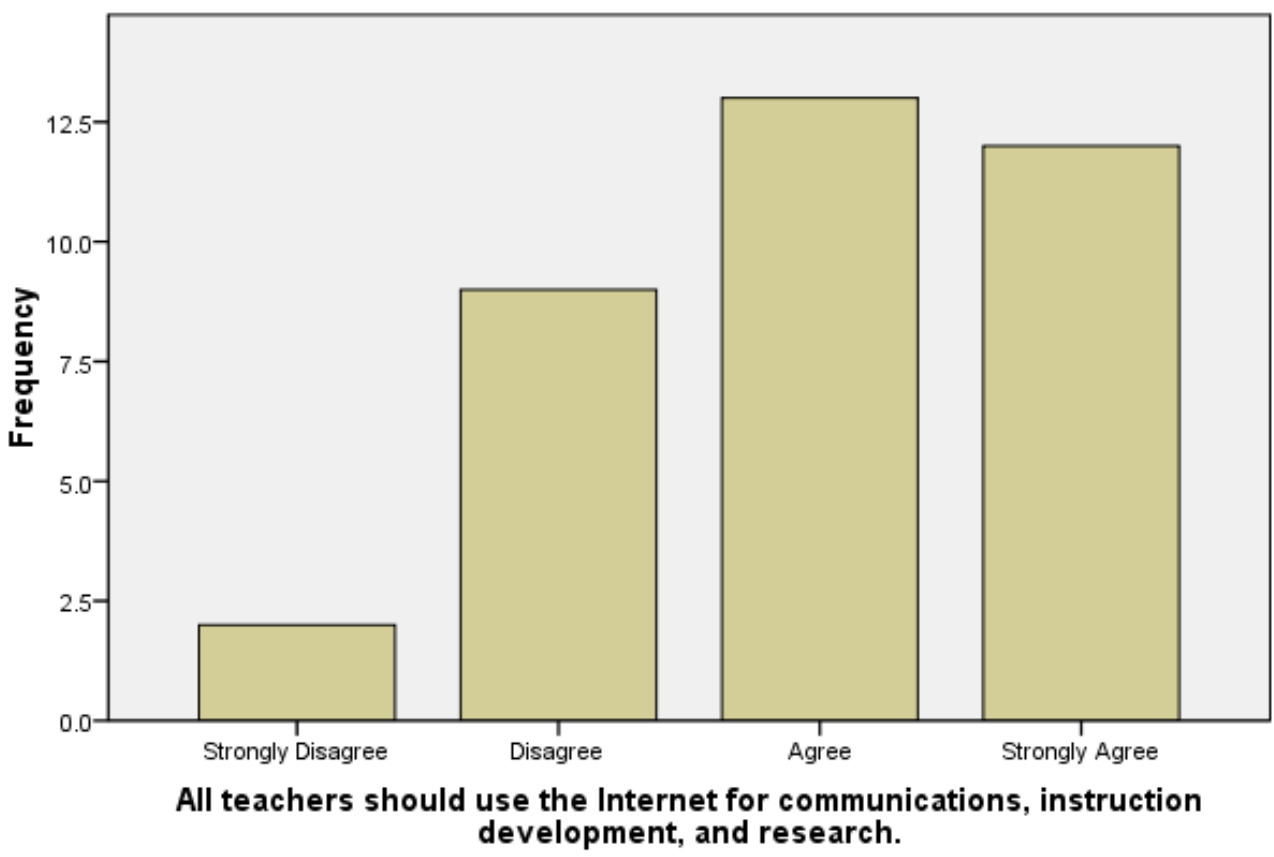

When asked if teachers should use the Internet, the responses were similar to the issue of students using the Internet. The responses were again mixed. A majority 
selected "agree" or "strongly agree" (69.4\%), but a representative group of $25 \%$, indicated "disagree". The mean for this question is also similar to the question about the student internet use 2.97 (teacher) and 2.92 (student)(see Table 17 and Figure 11).

Table 18

Question 9 L: Frequency (Concerned about having Time to Use Computers)

\begin{tabular}{|l|l|r|r|r|r|}
\hline \multicolumn{2}{|l|}{ I am concerned about having enough time to learn about computers so that I can use them } \\
effectively. & Frequency & Percent & Valid Percent & $\begin{array}{c}\text { Cumulative } \\
\text { Percent }\end{array}$ \\
\hline \multirow{3}{*}{ Valid } & 1 Strongly Disagree & 4 & 11.1 & 11.1 & 11.1 \\
\cline { 2 - 7 } & 2 Disagree & 6 & 16.7 & 16.7 & 27.8 \\
\cline { 2 - 7 } & 3 Agree & 16 & 44.4 & 44.4 & 72.2 \\
\cline { 2 - 7 } & 4 Strongly Agree & 10 & 27.8 & 27.8 & 100.0 \\
\hline \multirow{2}{*}{ Mean } & 2.89 & & & & \\
\end{tabular}


Figure 12: Frequency graph of responses for question $9 \mathrm{~L}$ (Concerned about having time to use computers).

\section{I am concerned about having enough time to learn about computers so that I can use them effectively.}

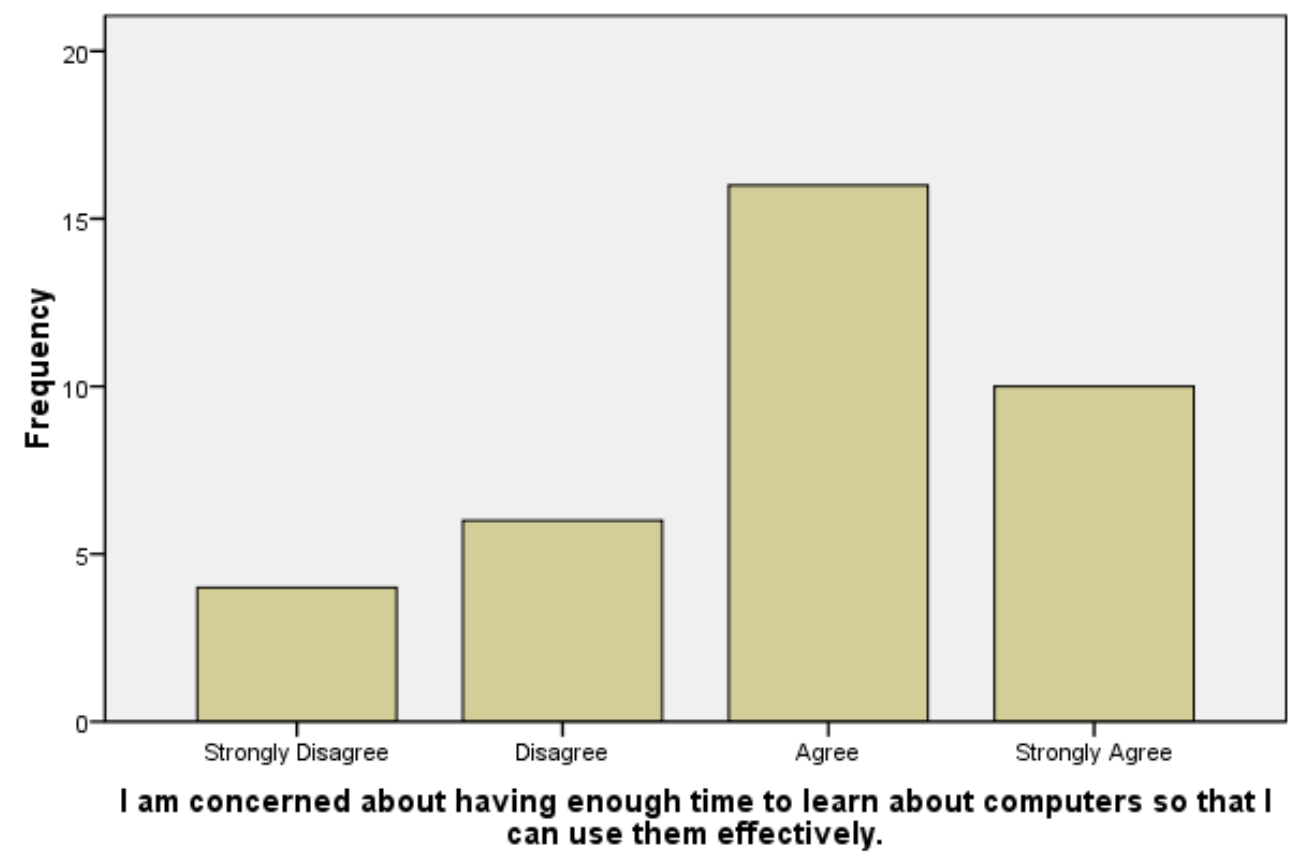

This question looks at having enough time to learn about computers. The most frequent response was "agree" with $44.4 \%$ of the participants answering this way. The majority of the participants $(72.2 \%)$ responded "agree" or "strongly agree". This question was considered as negative, due to the feeling that teachers who have higher anxiety towards computers may say they don't have "time" to use them. The higher mean of 2.89 would indicate a higher level of anxiety in the negative structure of this question (see Table 18 and Figure 12). 
Table 19

Question 9 M: Frequency (Computers have Limited Application in my Subject)

\begin{tabular}{|l|l|r|r|r|r|}
\hline \multicolumn{6}{|c|}{ Computer technology and the Internet have limited application in the subject I teach. } \\
\hline \multirow{5}{*}{} & & Frequency & Percent & Valid Percent & $\begin{array}{c}\text { Cumulative } \\
\text { Percent }\end{array}$ \\
\hline \multirow{4}{*}{ Valid } & 1 Strongly Disagree & 11 & 30.6 & 30.6 & 30.6 \\
\cline { 2 - 7 } & 2 Disagree & 18 & 50.0 & 50.0 & 80.6 \\
\cline { 2 - 7 } & 3 Agree & 5 & 13.9 & 13.9 & 94.4 \\
\cline { 2 - 7 } & 4 Strongly Agree & 2 & 5.6 & 5.6 & 100.0 \\
\hline \multirow{2}{*}{ Mean } & 1.94 & & & & \\
\hline
\end{tabular}

Figure 13: Frequency graph of responses for question $9 \mathrm{M}$ (Computers have limited application in my subject).

Computer technology and the Internet have limited application in the subject I teach.

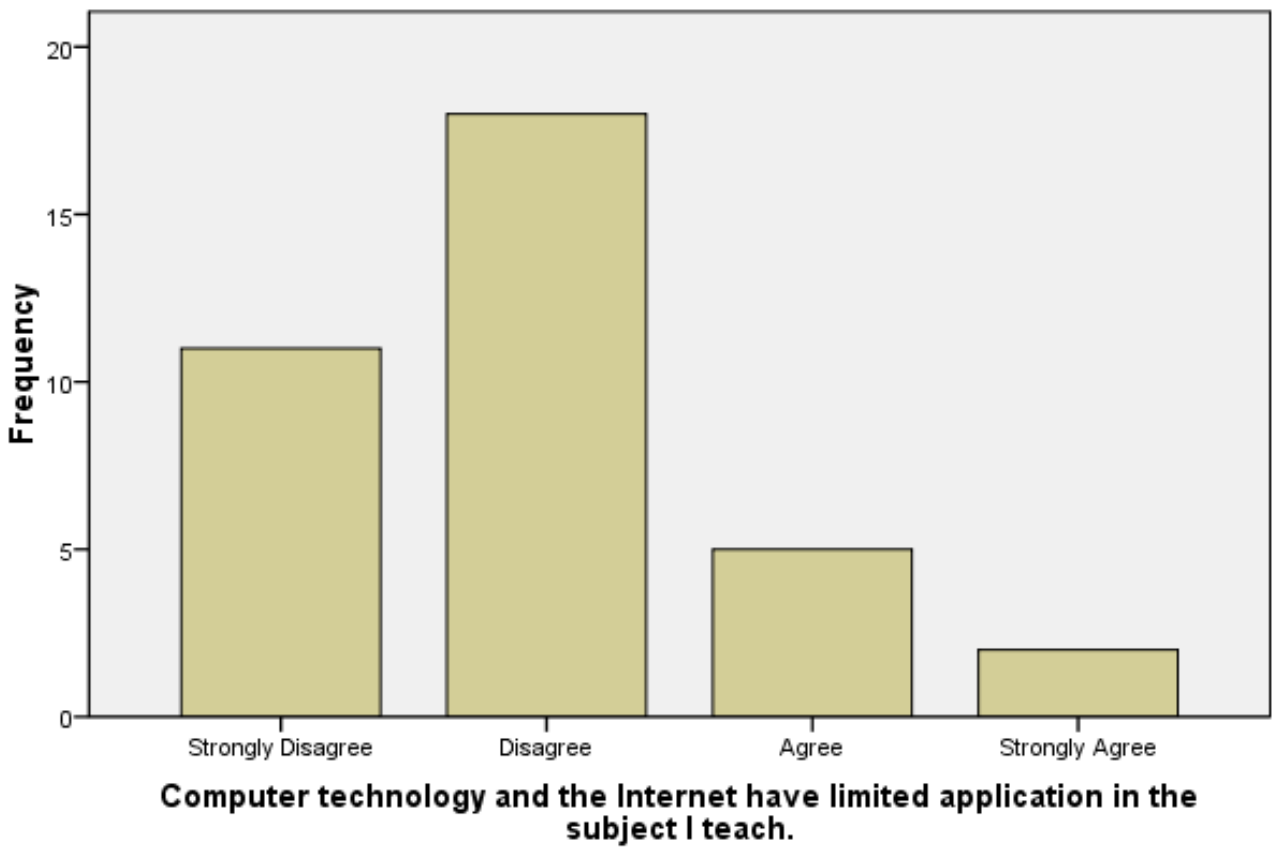


A majority of the participants (50\%) disagreed with this question. An overall percentage of $80.6 \%$ chose disagree or strongly disagree. This question is worded negatively, so a majority of people responding in disagreement shows a lessened level of anxiety. The mean for this question is 1.94 , showing that the teachers $d o$ feel there are applications available for their subject area (see Table 19 and Figure 13).

An anxiety mean score for the group. Secondly, the data were re-analyzed to determine an "attitude/anxiety" mean for the group. For this data, each of the negatively worded questions (as described in the methodology section) were re-coded. For example, in question 9D the question states "I am not interested in learning about computers." A person who responded "(4) strongly Agree” may indicate that person has a negative attitude/anxiety towards computer. Yet, in the question 9E, "Learning to use computers will make me a more effective teacher" a “(4) strongly agree” response would more likely indicate a positive attitude/anxiety level towards the technology. For the second part of the analysis, question 9D would be converted to a "1" response, while question 9E would stay as a "4". Thus, a lower mean indicates higher attitude/anxiety and a higher mean indicates lower attitude/anxiety. The converted codes would provide a consistent mean for that person, with all responses focused in the same direction. Below is a mean score for each question with negative questions converted. 
Table 20

Analysis with Means (converted) for Each Question

\begin{tabular}{|c|c|c|c|c|c|}
\hline \multicolumn{6}{|c|}{ Statistics } \\
\hline & $\begin{array}{c}\text { Question } \\
91\end{array}$ & $\begin{array}{c}\text { Question } \\
9 \mathrm{~J}\end{array}$ & $\begin{array}{c}\text { Question } \\
9 \mathrm{~K}\end{array}$ & $\begin{array}{c}\text { Question } 9 \\
\text { L Converted }\end{array}$ & $\begin{array}{c}\text { Question } 9 \\
\text { M } \\
\text { Converted }\end{array}$ \\
\hline Mean & 3.31 & 2.92 & 2.97 & 2.56 & 3.06 \\
\hline
\end{tabular}

Overall mean for all

Questions: 2.94

Table 20

shows the breakdown

of the means per question. All questions are now geared in the same direction. A higher mean would indicate a lower level of anxiety and a better attitude towards computers as a whole. A lower mean would indicate a higher level of anxiety/attitude for the group as a whole. The mean of 2.94 would indicate above a moderate/good anxiety level. (4 would

\begin{tabular}{|c|c|c|c|c|c|c|c|c|}
\hline \multicolumn{9}{|c|}{ Anxiety Means for all questions in Question 9} \\
\hline & $\begin{array}{c}\text { Question } \\
9 \mathrm{~A}\end{array}$ & $\begin{array}{c}\text { Question } \\
9 \mathrm{~B} \\
\text { Converted }\end{array}$ & $\begin{array}{c}\text { Question } \\
9 \mathrm{C}\end{array}$ & $\begin{array}{c}\text { Question } \\
\text { 9D } \\
\text { Converted }\end{array}$ & $\begin{array}{c}\text { Question } \\
9 \mathrm{E}\end{array}$ & $\begin{array}{c}\text { Question } \\
9 \mathrm{~F}\end{array}$ & $\begin{array}{c}\text { Question } \\
9 \mathrm{G} \\
\text { Converted }\end{array}$ & $\begin{array}{c}\text { Question } \\
9 \mathrm{H} \\
\text { Converted }\end{array}$ \\
\hline Mean & 3.18 & 2.06 & 2.89 & 3.0972 & 2.99 & 3.22 & 2.83 & 3.03 \\
\hline
\end{tabular}
mean no anxiety/complete comfort and 1 would equal high anxiety).

How does this compare with the interview and open-ended questions that address the level of anxiety/comfort level? Table 21(below) summarizes the responses from interview question 4/open-ended survey question 14: "Briefly describe your comfort/anxiety level in using computer technology as an instructional tool". 
Table 21

Self-described Comfort and Anxiety Level

\begin{tabular}{|l|c|}
\hline \multicolumn{1}{|c|}{ Self-described comfort/anxiety level } & number of responses \\
\hline High Anxiety (1) & 3 \\
\hline Not very Comfortable (2) & 2 \\
\hline Some Frustration (2) & 7 \\
\hline Pretty Comfortable (3) & 3 \\
\hline Very Little Anxiety (3) & 8 \\
\hline Complete Ease/Very Comfortable (4) & \\
\hline
\end{tabular}

The results from these questions show that 18 people have a moderate to better comfort level, while seven people have a higher anxiety level. These numbers would appear to be similar to the survey findings. When assigning point values on the same scale as the other question, the mean for this would be 3.10 , which would fall in the "pretty comfortable" which would be comparable to "moderate comfort" in the question 9 analysis. So to compare the two means from the questions, 2.94 and 3.10 are close means, which indicates the triangulation of using statistical data questions, interpreted data for interviews/open ended questions and also quotes indicating the reliability of the anxiety level scores. Here are samplings of the quotes from the participants when addressing the comfort/anxiety level, broken up into categories.

High Anxiety. "I have fairly high anxiety...I need more training." "I am the weakest technology person in the room (compared to students)." 
Moderate Anxiety. "I am pretty comfortable, but I always need continual training", "I am comfortable when using a technology that I am competent in, otherwise I am uncomfortable", "I am very comfortable with Gradequick, Edline and posting things to Edline - not as comfortable with programs I don't have training with", "My anxiety is 50/50. I am not afraid to jump in, but I do get anxious with new programs."

Lower Anxiety. "I feel extremely comfortable", "I am comfortable with computers, there is just not enough time to use them", "I am extremely comfortable with technology, if you mess up you can fix it."

No Desire. "I feel confident I could use it completely, but I have no time or no desire", "There is a certain amount of people that just don't like the computers".

Principal's overall view on teachers' anxiety level, "The anxiety level varies in the school. Some teachers are extremely comfortable, while others are scared. The teachers are getting much better as they are getting the support they need."

These results help demonstrate the correlation with training and anxiety that was discussed previously. Teachers that had high anxiety addressed the need for more training. Those teachers with moderate anxiety stated that the programs they were comfortable with caused no anxiety; it was the new programs that they had not had training which created some anxiety.

Age range versus computer use at school? Does age have an effect on how often the teachers use computers at school and at home? This analysis compared the different age groups collected from the demographic questions, coded as follows: (1) under 30 (2) 30-45 (3) Over 45 and compares the means with the response to question 3 " How often do you use computers at school?" and question 4 "How often do you use computers at 
home?" This analysis was done using a means comparison with the dependent variable being the "how often do you use computers at school (home)" and the independent variable being the age range of the participant.

Reports were created to show the mean, standard deviation and ANOVA (Analysis of variance) table for each age range category. ANOVA is a statistical technique that looks at the variance in distribution in scores by separating the factors and tests for significant differences between means. A box plot chart also shows the breakdown in age/computer use categories, showing the mean and the range of each group.

Table 22

Age range and question 3(Computer Use at School): ANOVA

\begin{tabular}{|l|r|r|r|}
\hline \multicolumn{4}{|c|}{ How often do you use computers at school? } \\
\hline Age & \multicolumn{1}{|c|}{ Mean } & $\mathrm{N}$ & Std. Deviation \\
\hline Under 30 years & 4.50 & 6 & .837 \\
\hline $30-45$ years & 4.00 & 10 & .943 \\
\hline Over 45 years & 4.20 & 20 & 1.005 \\
\hline Total & 4.19 & 36 & .951 \\
\hline
\end{tabular}

\begin{tabular}{|c|c|c|c|c|c|c|c|}
\hline \multicolumn{8}{|c|}{ ANOVA Table } \\
\hline & & & $\begin{array}{l}\text { Sum of } \\
\text { Squares }\end{array}$ & $\mathrm{df}$ & $\begin{array}{l}\text { Mean } \\
\text { Square }\end{array}$ & $\mathrm{F}$ & Sig. \\
\hline \multirow{3}{*}{$\begin{array}{l}\text { How often do you use } \\
\text { computers at school? * } \\
\text { Age }\end{array}$} & Between Groups & (Combined) & .939 & 2 & .469 & .505 & .608 \\
\hline & Within Groups & & 30.700 & 33 & .930 & & \\
\hline & Total & & 31.639 & 35 & & & \\
\hline
\end{tabular}


Figure 14: Range and means for age range and computer use at school.

\section{Interaction for Age Range and Computer Use at School}

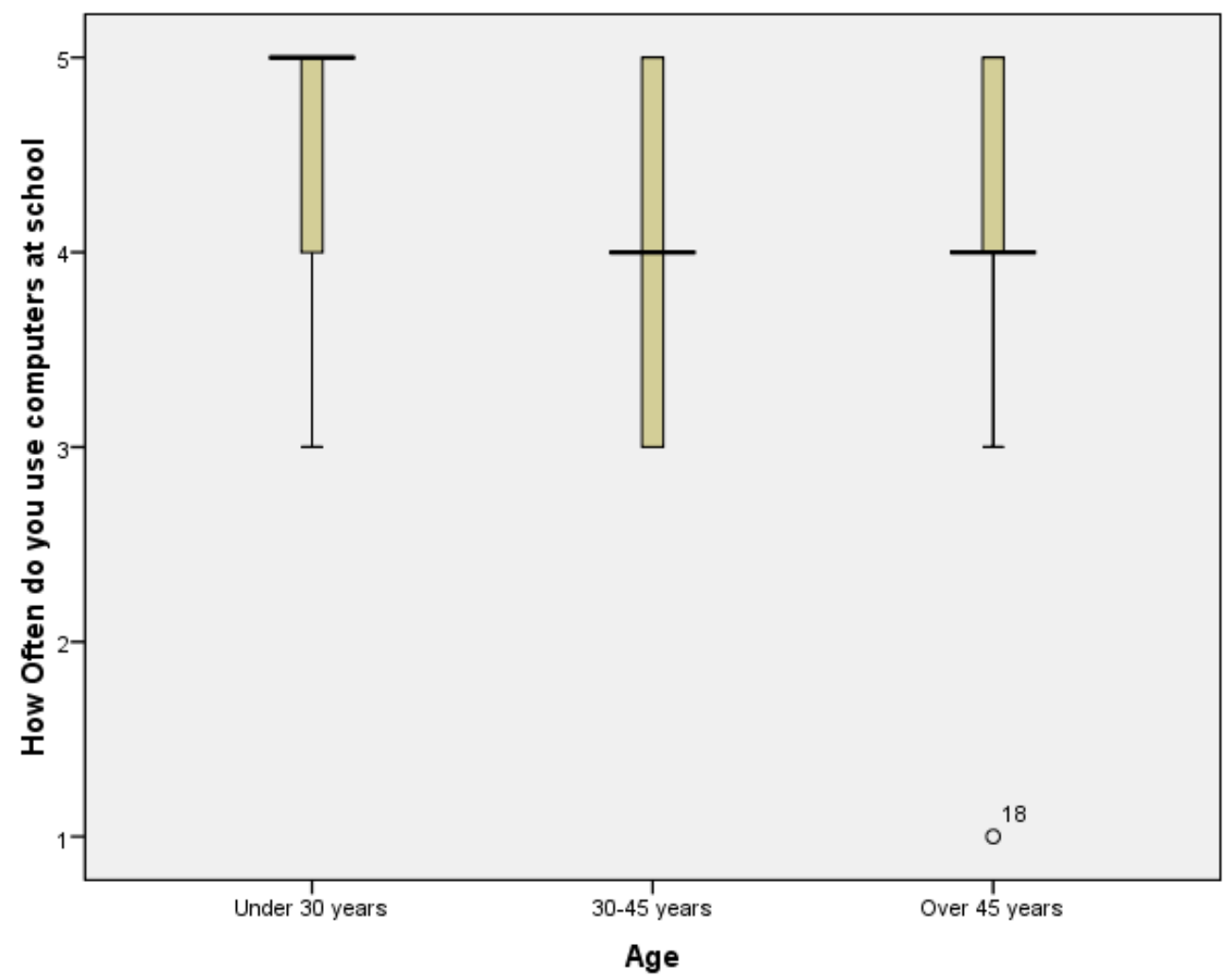

In this analysis the degrees of freedom (df) are 2 and 33. This was used to calculate the F-ratio to determine the F distribution at a .05 level of significance. The $f$ distribution chart can be placed in a bell shape distribution curve, allowing normal variations of means in the population of this size. If the calculated F-value would fall within the $99.05 \%$ of normal distribution of mean variance, the analysis would show no significant differences in the mean categories up to a .05 level of significance. If the ANOVA reveals a significance less than or equal to .05 , that means that some aspect of those variable means fall in the "tail" of the bell shape curve cut off. Results in the "tail" indicate that there is a significant difference in the variable means.

For this question, the level of significance was calculated at .608; it is not $<.05$, thus accepting the null hypothesis. This analysis of variance showed that there were no 
significant differences in the means in age range and how often the teachers use the computers at school (see Table 22 and Figure 14).

Table 23

Age range and question 4 (Computer Use at Home): ANOVA

\begin{tabular}{|l|r|r|r|}
\hline \multicolumn{4}{|c|}{ How often do you use computers at home? } \\
\hline Age & \multicolumn{1}{|c|}{ Mean } & $\mathrm{N}$ & Std. Deviation \\
\hline Under 30 years & 4.17 & 6 & .408 \\
\hline $30-45$ years & 3.80 & 10 & 1.229 \\
\hline Over 45 years & 3.95 & 20 & 1.099 \\
\hline Total & 3.94 & 36 & 1.040 \\
\hline
\end{tabular}

\begin{tabular}{|c|c|c|c|c|c|c|c|}
\hline \multicolumn{8}{|c|}{ ANOVA Table } \\
\hline & & & \begin{tabular}{|c|} 
Sum of \\
Squares
\end{tabular} & $\mathrm{df}$ & Mean Square & $\mathrm{F}$ & Sig. \\
\hline \multirow{3}{*}{$\begin{array}{l}\text { How often } \\
\text { do you use } \\
\text { computers } \\
\text { at home? * } \\
\text { Age }\end{array}$} & $\begin{array}{l}\text { Between } \\
\text { Groups }\end{array}$ & (Combined) & .506 & 2 & .253 & .223 & .801 \\
\hline & \multicolumn{2}{|c|}{ Within Groups } & 37.383 & 33 & 1.133 & & \\
\hline & \multicolumn{2}{|l|}{ Total } & 37.889 & 35 & & & \\
\hline
\end{tabular}


Figure 15: Range and means for age range and computer use at home.

\section{Interaction for Age Range and Computer Use at Home}

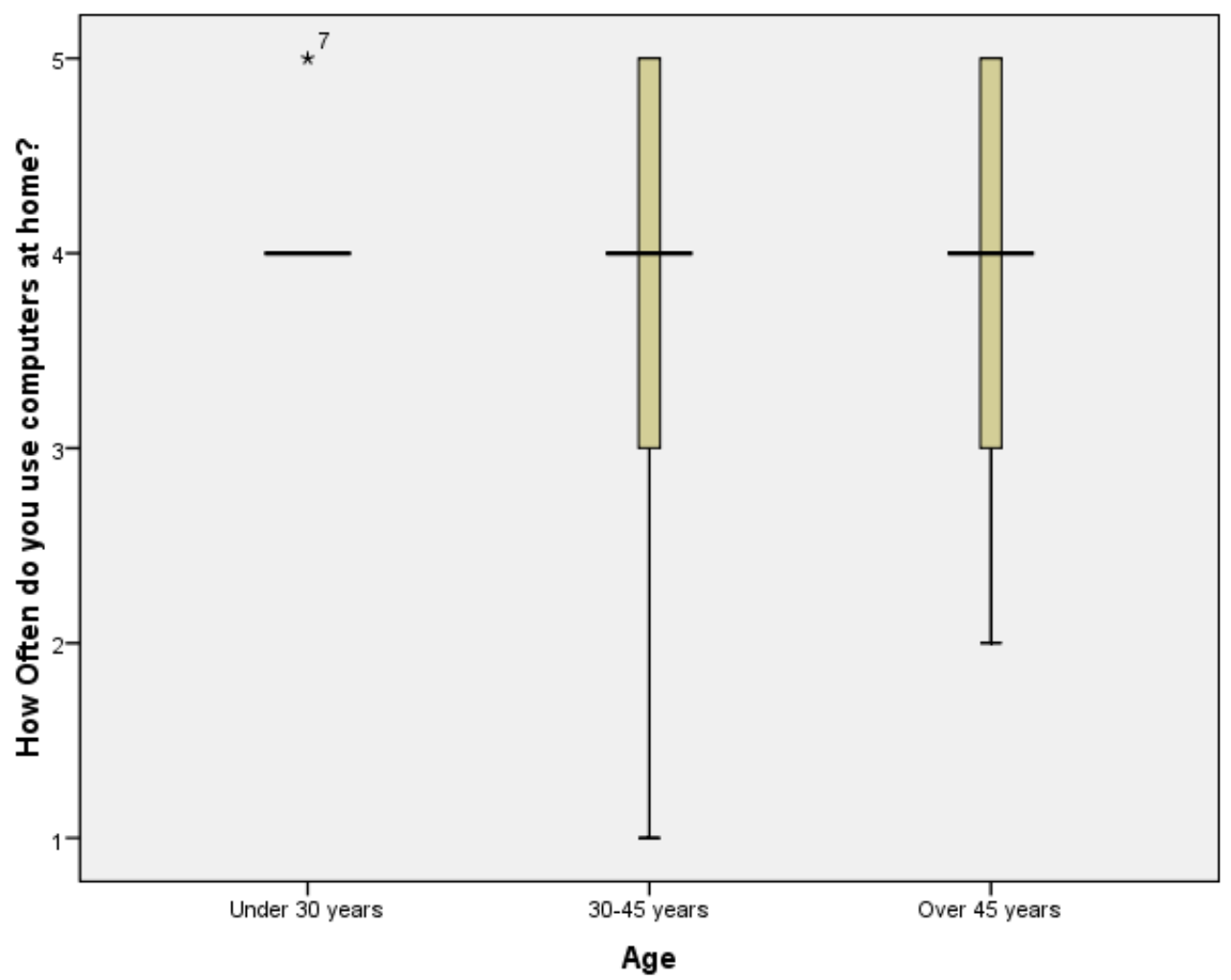

In the ANOVA analysis for this question, the F-ratio distribution showed a significance of .801 . This was not $<.05$, meaning acceptance of the null hypothesis. There were no significance differences in the variables of age range and how often the teachers use the computers at home. Actually with the significance number so near one, it shows very little degree of variance in these categories (see Table 23). This can also be seen when viewing the similarities in the box plot chart (see Figure 15).

\section{Knowledge of computer technologies vs. amount of computer training. Does} knowledge of computers have any relationship to the amount of training the teachers received? This analysis first looked at the questions using frequency data statistics and charts independently to provide information on how the teachers answered these 
questions. A further analysis using an ANOVA showed if there were any significances in these categories.

When analyzing the means for the ANOVA, the independent variable was computer training and the dependent variable was computer knowledge. The analysis used a level of significance at .05 .

Question 1: "How would you rate your knowledge of computer technologies?" Question 6: "How much training have your received using the computer as an instructional tool?" 
Table 24

Question 1: Frequency (Computer Knowledge)

\begin{tabular}{|l|l|r|r|r|r|}
\hline \multicolumn{2}{|c|}{ Computer Knowledge } \\
\hline \multirow{5}{*}{ Valid } & Frequency & Percent & Valid Percent & $\begin{array}{r}\text { Cumulative } \\
\text { Percent }\end{array}$ \\
\cline { 2 - 7 } & 1 Poor & 1 & 2.8 & 2.8 & 2.8 \\
\cline { 2 - 7 } & 2 Limited & 3 & 8.3 & 8.3 & 11.1 \\
\cline { 2 - 7 } & 2.5 & 1 & 2.8 & 2.8 & 13.9 \\
\cline { 2 - 7 } & 3 Fair & 5 & 13.9 & 13.9 & 27.8 \\
\cline { 2 - 7 } & 4 Good & 20 & 55.6 & 55.6 & 100.0 \\
\cline { 2 - 7 } & 5 Excellent & 6 & 16.7 & 16.7 & \\
\cline { 2 - 7 } & Total & 36 & 100.0 & 100.0 & \\
\hline
\end{tabular}

Figure 16: Rating of computer knowledge.

How would you rate your knowledge of computer technologies?

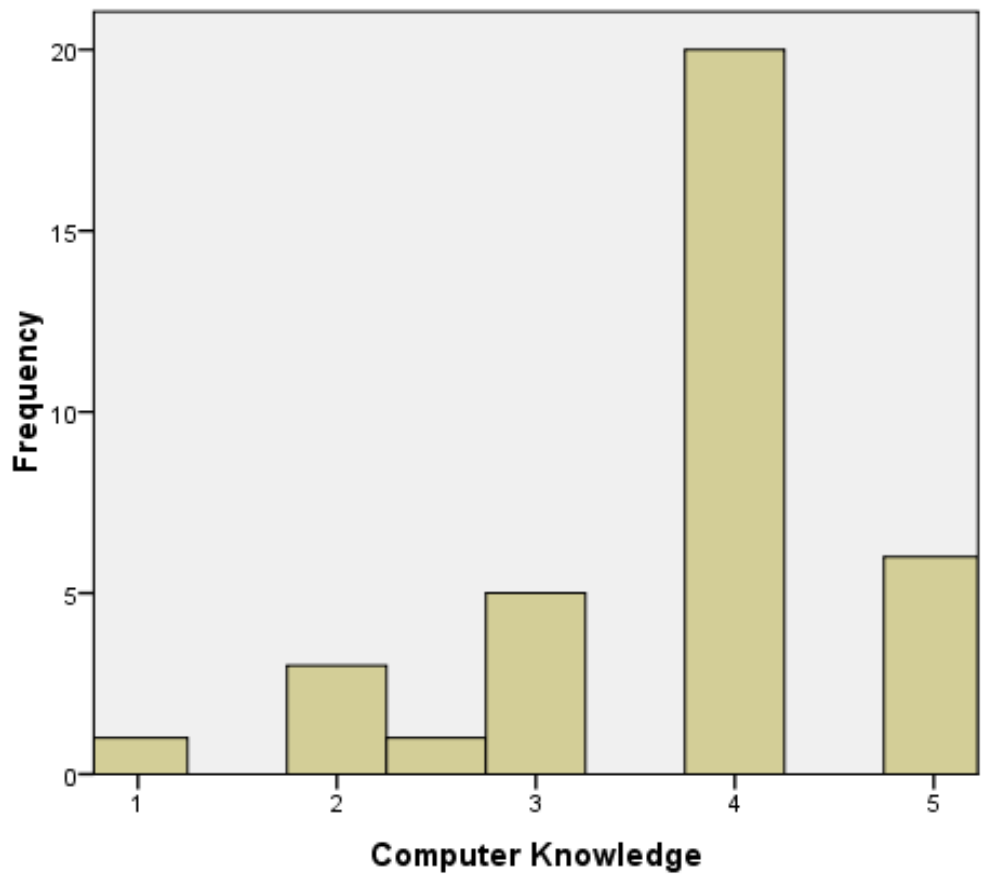

$\begin{aligned} & \text { Mean }=3.74 \\ & \text { Std. Dev. }=0.952\end{aligned}$

$\mathrm{N}=36$ 
The frequency distribution on how the teachers self-rated their computer knowledge clearly showed a majority $(55.6 \%)$ of the participants said "good". Also significant was only one teacher said "poor" for knowledge level (see Table 24 and Figure 16).

Table 25

Question 6: Frequency (Computer Training)

\begin{tabular}{|l|l|r|r|r|r|}
\hline \multicolumn{7}{|c|}{} & & & & \\
\hline & & Crequency & Percent & Valid Percent & $\begin{array}{c}\text { Cumulative } \\
\text { Percent }\end{array}$ \\
\hline \multirow{6}{*}{ Valid } & 1 Little or no training & 1 & 2.8 & 2.8 & 2.8 \\
\cline { 2 - 7 } & 2 & 2 & 5.6 & 5.6 & 8.3 \\
\cline { 2 - 7 } & 3 Moderate training & 16 & 44.4 & 44.4 & 52.8 \\
\cline { 2 - 7 } & 3.5 & 1 & 2.8 & 2.8 & 55.6 \\
\cline { 2 - 7 } & 4 & 14 & 38.9 & 38.9 & 94.4 \\
\cline { 2 - 7 } & 5 Extensive Training & 2 & 5.6 & 5.6 & 100.0 \\
\hline
\end{tabular}


Figure 17: Computer training frequency.

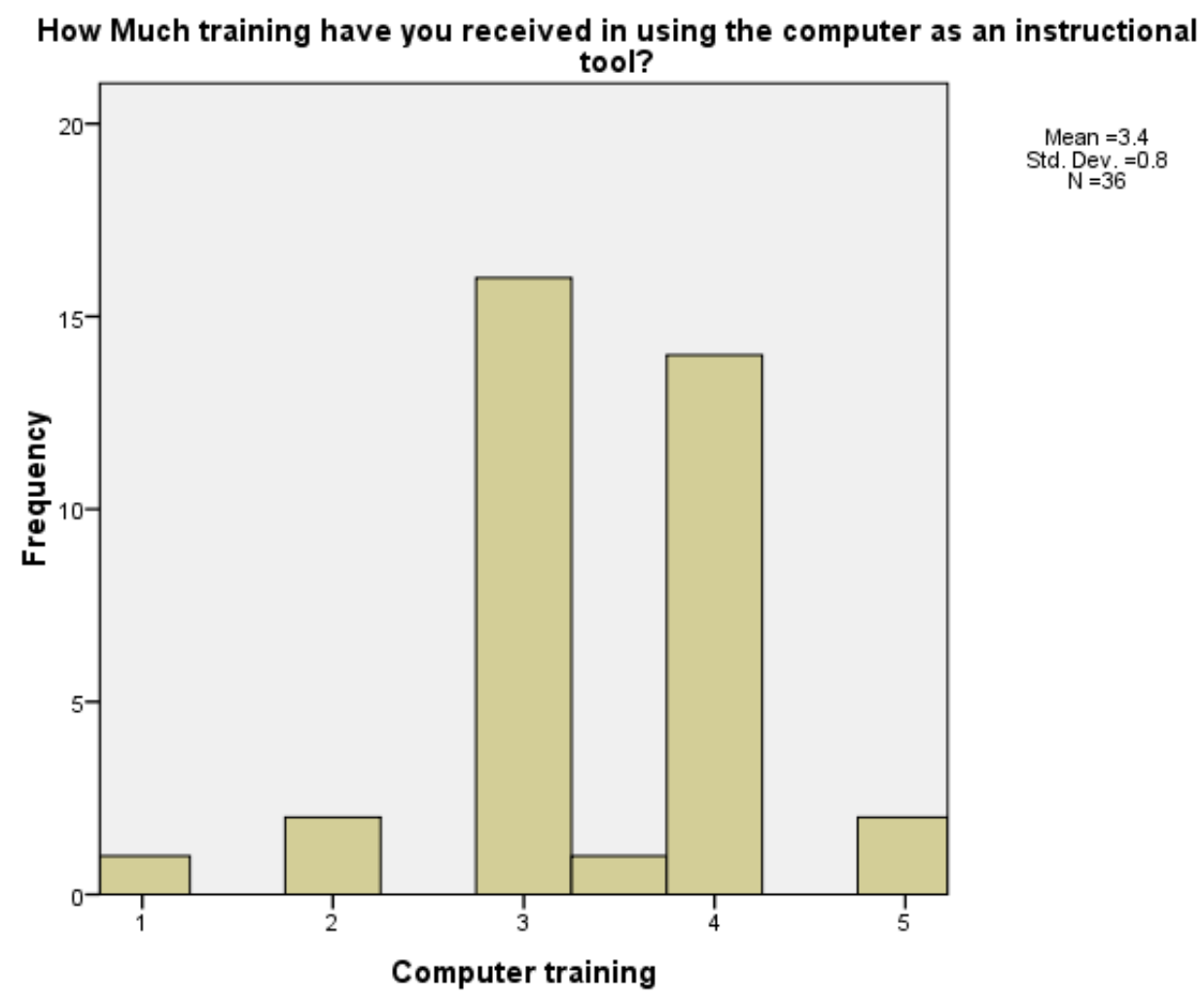

The teachers self-rated their level of computer training. The largest response was (3) moderate training with $44.4 \%$ of the participants selecting that answer. Also important to note was $38.9 \%$ of the participants answered (4) which was above moderate and below extensive (see Table 25 and Figure 17). 
Table 26

Computer knowledge and Computer training: ANOVA

\begin{tabular}{|l|r|r|r|}
\hline \multicolumn{2}{|l|}{ Computer Knowledge } & & \\
\hline Computer training & \multicolumn{1}{|c|}{ Mean } & $\mathrm{N}$ & Std. Deviation \\
\hline 1 Little or no training & 4.00 & 1 & \\
\hline 2 & 2.00 & 2 & 1.414 \\
\hline 3 Moderate training & 3.69 & 16 & .704 \\
\hline 3.5 & 2.50 & 1 & .961 \\
\hline 4 & 4.00 & 14 & .707 \\
\hline 5 Extensive Training & 4.50 & 2 & .952 \\
\hline Total & 3.74 & 36 & \\
\hline
\end{tabular}

\begin{tabular}{|c|c|c|c|c|c|c|c|}
\hline \multicolumn{8}{|c|}{ ANOVA Table } \\
\hline & & & $\begin{array}{l}\text { Sum of } \\
\text { Squares }\end{array}$ & $d f$ & $\begin{array}{l}\text { Mean } \\
\text { Square }\end{array}$ & $F$ & Sig. \\
\hline \multirow{3}{*}{$\begin{array}{l}\text { Computer } \\
\text { Knowledge * } \\
\text { Computer } \\
\text { training }\end{array}$} & Between Groups & (Combined) & 9.806 & 5 & 1.961 & 2.682 & .041 \\
\hline & Within Groups & & 21.938 & 30 & .731 & & \\
\hline & Total & & 31.743 & 35 & & & \\
\hline
\end{tabular}

In the ANOVA analysis for this question, the F-ratio distribution showed a significance of .041 . At the .05 level of significance, this was $<.05$, so rejecting the null hypothesis(see Table 26). The population means are not all equal, within the categories of computer knowledge and computer training, the means showed significant variance (differences).

\section{Knowledge of Internet technologies vs. amount of Internet training. Does} knowledge of the use of Internet application have any relationship to the amount of training on using the Internet as a tool that the teachers received? This analysis first 
looked at the questions using frequency data statistics and charts independently to provide information on how the teachers answered these questions. A further analysis using an ANOVA looked for any significances in these categories means.

The following questions were used for this analysis:

Question 2: "How would your rate your knowledge of the use of Internet applications?"

Questions 7: "How much training have your received using the Internet as an instructional tool?" 
Table 27

Question 2: Frequency (Internet Knowledge)

\begin{tabular}{|l|l|r|r|r|r|}
\hline \multicolumn{7}{|c|}{ Knowledge of Internet Applications } \\
\hline & & & & & \multicolumn{2}{c|}{$\begin{array}{c}\text { Cumulative } \\
\text { Percent }\end{array}$} \\
\hline \multirow{5}{*}{ Valid } & Frequency & Percent & Valid Percent & 2.8 \\
\cline { 2 - 7 } & 1 Poor & 1 & 2.8 & 2.8 & 5.6 \\
\cline { 2 - 7 } & 2 Limited & 1 & 2.8 & 2.8 & 38.9 \\
\cline { 2 - 7 } & 3 Fair & 12 & 33.3 & 33.3 & 69.4 \\
\cline { 2 - 7 } & 4 Good & 11 & 30.6 & 30.6 & 100.0 \\
\cline { 2 - 7 } & 5 Excellent & 11 & 30.6 & 30.6 & \\
\hline
\end{tabular}

Figure 18: Knowledge of Internet application.

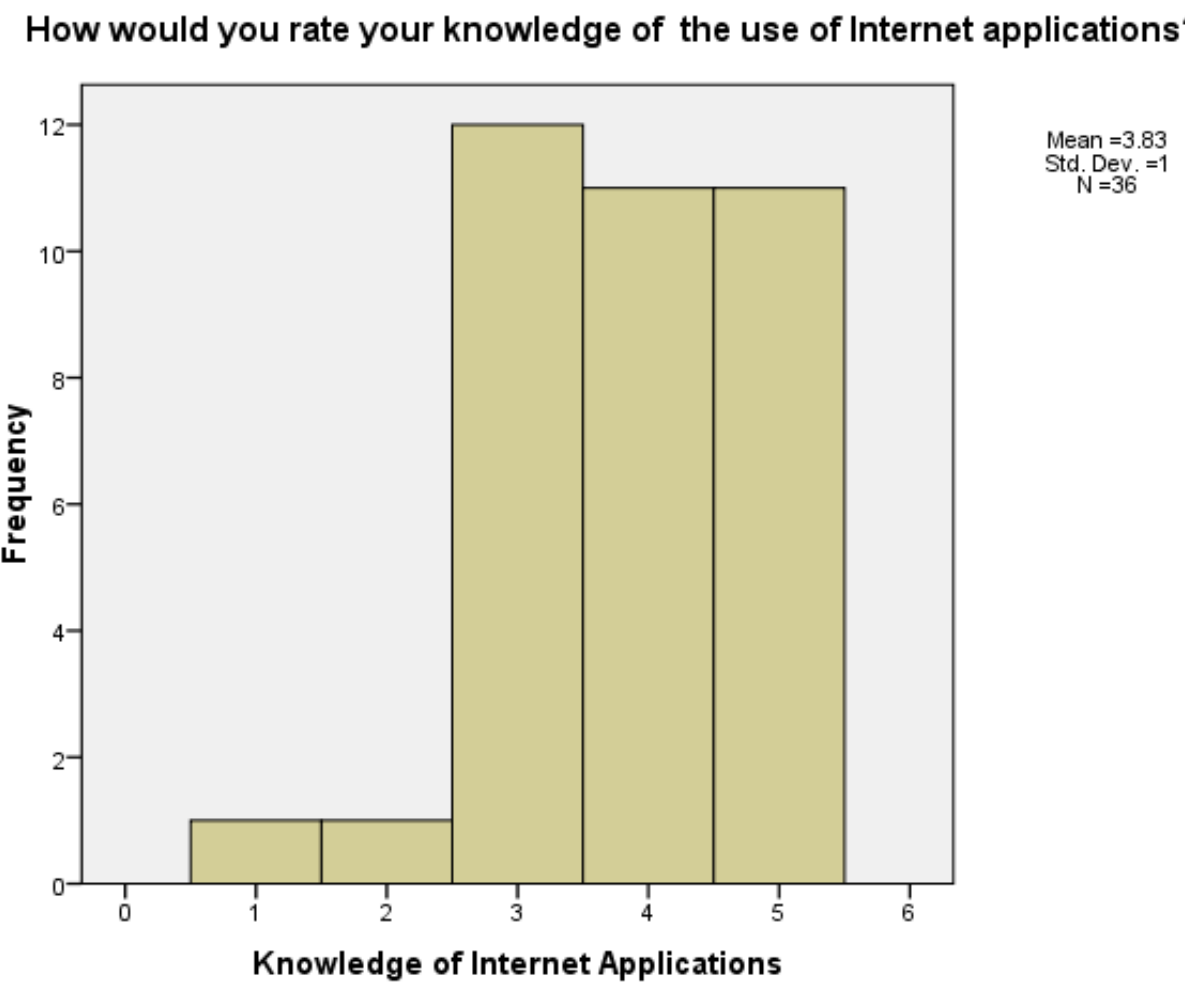

The more frequent response for participants when asked to self-rate their

knowledge of computer applications was (3) "Fair" with 12 people answering that way. Category 4 (good) and Category 5 (excellent) both had 11 people respond in those categories. A majority of the participants answered neutral or favorable in regards to 
their knowledge, while few people (2) responded negatively (see Table 27 and Figure 18).

Table 28

Question 7: Frequency (Internet Training)

\begin{tabular}{|c|c|c|c|c|c|}
\hline \multicolumn{6}{|c|}{ Internet training } \\
\hline & & Frequency & Percent & Valid Percent & $\begin{array}{c}\text { Cumulative } \\
\text { Percent }\end{array}$ \\
\hline \multirow[t]{6}{*}{ Valid } & 1 Little or no training & 5 & 13.9 & 13.9 & 13.9 \\
\hline & 2 & 1 & 2.8 & 2.8 & 16.7 \\
\hline & 3 Moderate training & 14 & 38.9 & 38.9 & 55.6 \\
\hline & 3.5 & 1 & 2.8 & 2.8 & 58.3 \\
\hline & 4 & 14 & 38.9 & 38.9 & 97.2 \\
\hline & 5 Extensive Training & 1 & 2.8 & 2.8 & 100.0 \\
\hline
\end{tabular}

Figure 19: Frequency of Internet training.

\section{How much training have you received on using the Internet as an instructional tool?}

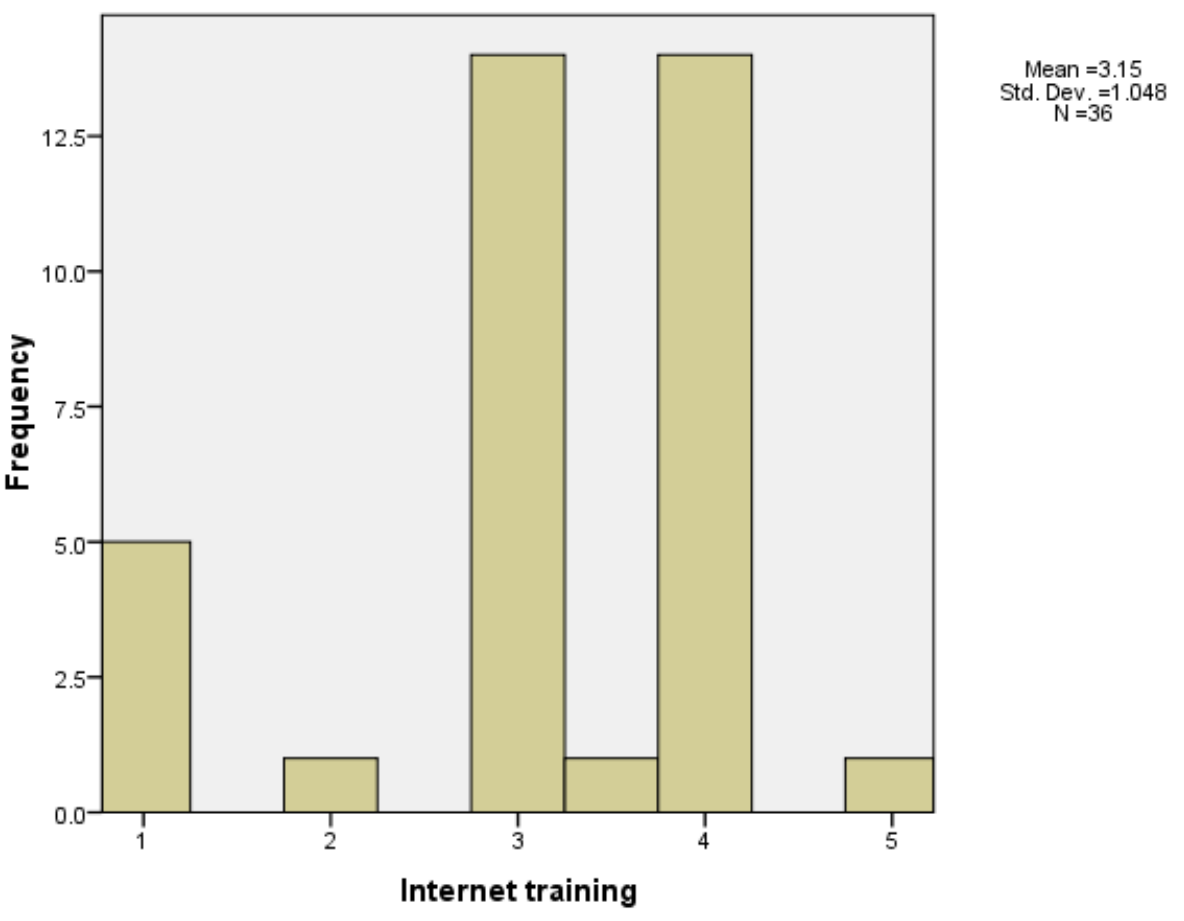


Of the participants, 29 responded (3) moderate or (4) between moderate and extensive. It is important to note that there is a group of 5 teachers who stated they had little or no training in using the Internet.

When analyzing the means for the ANOVA, the independent variable was Internet training and the dependent variable was Internet knowledge. The analysis used a significance of .05 (see Table 28 and Figure 19).

Table 29

Question 2 and Question 7 (Internet Knowledge and Internet Training): ANOVA

\begin{tabular}{|l|l|r|r|r|r|r|r|}
\hline \multicolumn{7}{|c|}{ ANOVA Table } \\
\hline
\end{tabular}

In the ANOVA analysis for this question, the F-ratio distribution showed a significance of .563 (see Table 29). At the .05 level of significance, this was not $<.05$, so not rejecting the null hypothesis. The population means for these variables are not significantly different, and presumed equal. Within the categories of Internet knowledge and Internet training, the means do not show significant variance (differences).

Area of specialization vs. computer use at school. Was there a relationship between the area of specialization and computer use at school? For this analysis an ANOVA was used to determine variance in the means of the population. For the ANOVA the independent variable was the amount of computer use at school and the 
dependent variable was the area of specialization (demographics). A box plot showed the means and ranges for each of the categories.

Here are the questions used for this analysis.

Question 3: "How often do you use the computers at school?"

Demographic: "What is your area of specialization: (Answers are coded as

follows: (1) English, (2) Math, (3) Social Studies, (4) Science, (5) Related Arts, (6)

Special Education."

Table 30

Amount of Computer Use at School and Area of Specialization: ANOVA

\begin{tabular}{|l|r|r|r|}
\hline \multicolumn{4}{|c|}{ How often do you use computers at school } \\
\hline $\begin{array}{l}\text { Area of } \\
\text { Specialization }\end{array}$ & Mean & $\mathrm{N}$ & Std. Deviation \\
\hline English & 4.44 & 9 & .882 \\
\hline Math & 4.00 & 3 & 1.000 \\
\hline Social Studies & 3.67 & 3 & .577 \\
\hline Science & 3.67 & 3 & .577 \\
\hline Related Arts & 4.30 & 10 & 1.337 \\
\hline Special Education & 4.17 & 6 & .753 \\
\hline Total & 4.18 & 34 & .968 \\
\hline
\end{tabular}

\begin{tabular}{|c|c|c|c|c|c|c|c|}
\hline \multicolumn{8}{|c|}{ ANOVA Table } \\
\hline & & & $\begin{array}{l}\text { Sum of } \\
\text { Squares }\end{array}$ & $\mathrm{df}$ & $\begin{array}{l}\text { Mean } \\
\text { Square }\end{array}$ & $F$ & Sig. \\
\hline \multirow{3}{*}{$\begin{array}{l}\text { How often do } \\
\text { you use } \\
\text { computers at } \\
\text { school * Area } \\
\text { of } \\
\text { Specialization }\end{array}$} & Between Groups & (Combined) & 2.452 & 5 & .490 & .482 & .787 \\
\hline & Within Groups & & 28.489 & 28 & 1.017 & & \\
\hline & Total & & 30.941 & 33 & & & \\
\hline
\end{tabular}


Figure 20: Comparison of area of specialization and computer use at school.

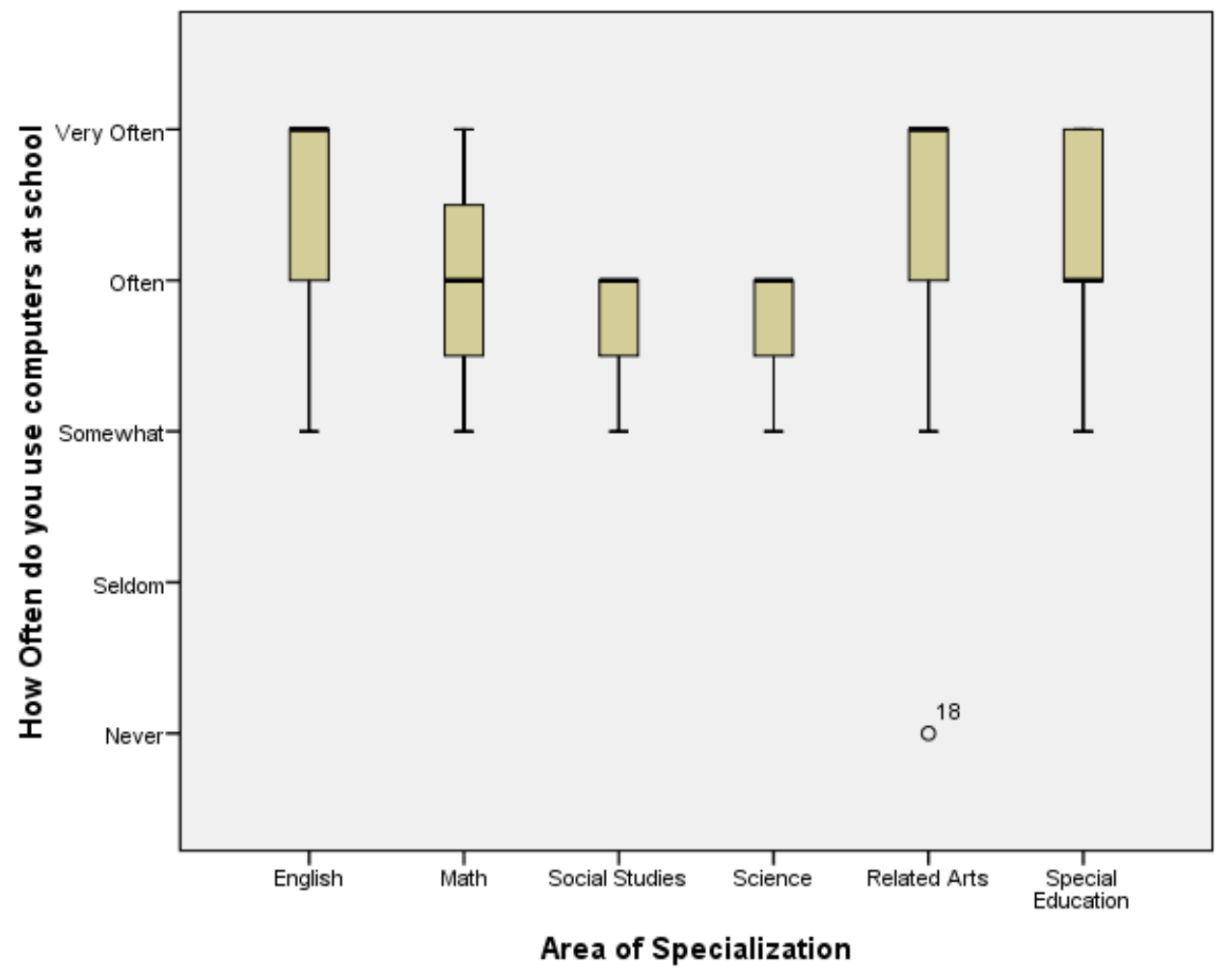

The ANOVA results showed a significance of .787, which at .05 level of significance proves to be not significant, thus accepting the null hypothesis (see Table 30 and Figure 20). There was no significant variance in means for the different areas of specialization and how often the teachers use the computer at school. It is important to note that some areas of specialization have many more teachers than others. So, the range is more skewed by participants in a group with 3 people, versus one with 18 people. The box plot showed that English and Related Arts teachers had the highest means for computer use, while social studies and science teachers had the lowest mean.

Years of teaching experience vs. amount of instructional technology training received. This question looked for any relationship between years of teaching experience 
and amount of instructional technology training. Years of teaching experience data were gathered from the self-reported demographics section. The categories for this question were coded as follows: (1) 5 years and under, (2) 6-10 years, (3) 11-20 years, (4) over 20 years. Amount of instructional technology training received was based on question 8: "How do you feel about the overall amount of instructional technology training you have received?"

An ANOVA was conducted to determine if there are any mean differences among the factors in these two categories. (see Table 31) The dependent variable was the years of teaching experience and the independent variable was the overall level of training.

\section{Table 31}

Years of Experience and Training: ANOVA

\begin{tabular}{|l|r|r|r|}
\hline Years of Teaching & & & \\
\hline $\begin{array}{l}\text { Overall Instructional } \\
\text { Technology Received }\end{array}$ & Mean & $\mathrm{N}$ & Std. Deviation \\
\hline Less Training Needed & 3.00 & 1 & .000 \\
\hline 2 & 4.00 & 2 & 1.328 \\
\hline 2.5 & 3.00 & 1 & 1.088 \\
\hline Moderate Training & 2.07 & 14 & .707 \\
\hline 4 & 3.37 & 16 & 1.282 \\
\hline Extensive Training & 3.50 & 2 & \\
\hline Total & 2.89 & 36 & \\
\hline
\end{tabular}




\begin{tabular}{|l|l|r|r|r|r|r|r|}
\hline \multicolumn{2}{|c|}{ ANOVA Table } \\
\hline
\end{tabular}

Figure 21: Comparison of technology training and years of teaching.

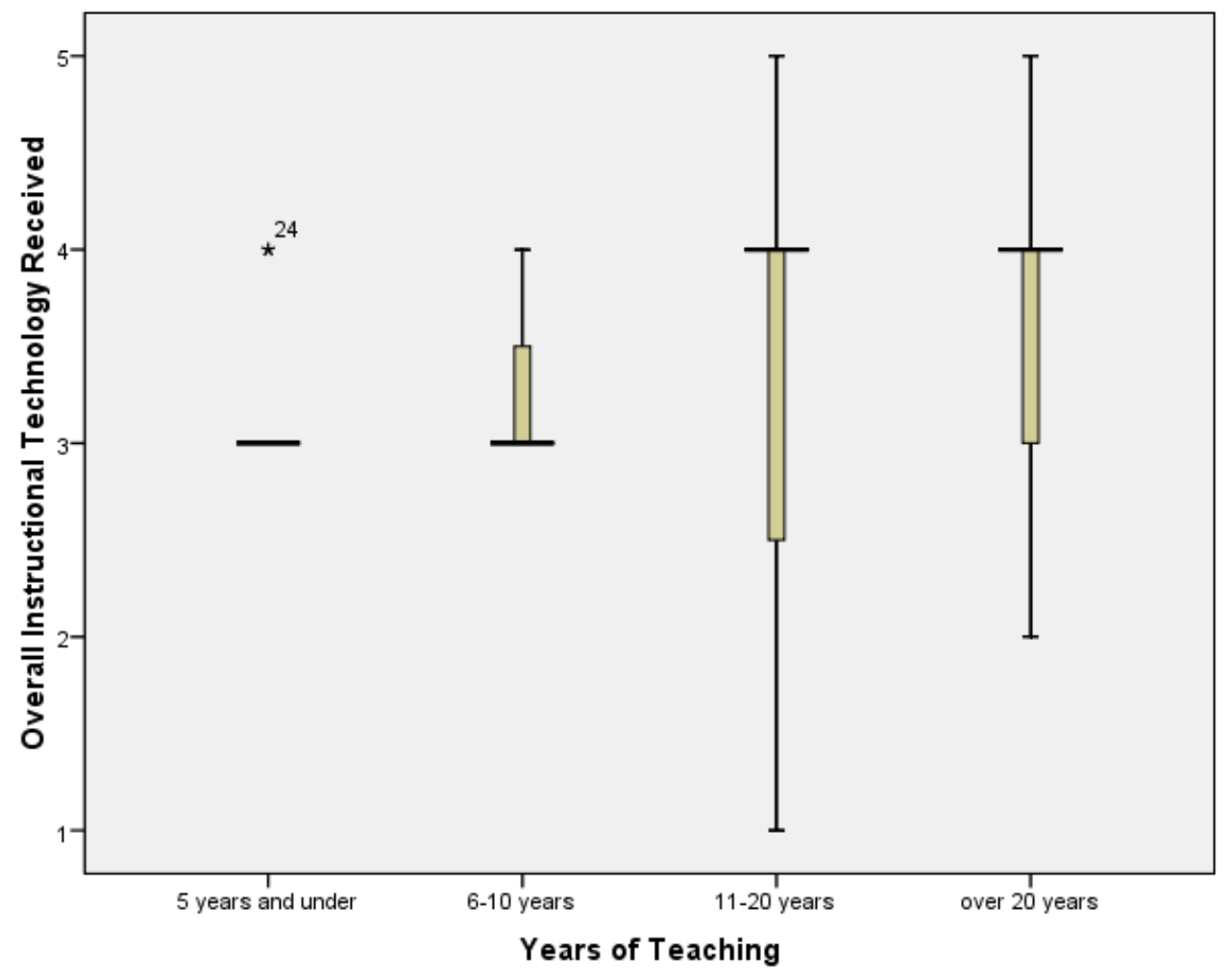

The ANOVA analysis showed that there was a .062 level of significance in years of teaching experience and overall teacher training (see Table 31 and Figure 21). With a .05 level of significance, this would accept the null hypothesis. Differences in the means of the group would not be considered significant.

Several interesting things were noted while looking at this frequency chart. All of the teachers in the 5 and under category answered "moderate" training. The 2 nd category 
(6-10 years) also had a mean of "moderate". The $3^{\text {rd }}$ category (11-20 years) had a higher mean of 4 (between moderate and extensive) but the range landed from less training needed to extensive training. The $4^{\text {th }}$ category also had a higher mean.

How many teachers had the opportunity to participate in the 1997 survey? By looking at the demographic question "How many years have you been at this school?" the data were coded numerically (1) under 10 years and (2) over 10 years. The following frequency chart and pie chart represent this data.

Table 32

Years of Teaching at the School: Frequency

\begin{tabular}{|c|c|c|c|c|c|}
\hline \multicolumn{6}{|c|}{ Years at the school } \\
\hline & & Frequency & Percent & Valid Percent & $\begin{array}{c}\text { Cumulative } \\
\text { Percent }\end{array}$ \\
\hline \multirow[t]{2}{*}{ Valid } & Less than 10 years at school & 21 & 58.3 & 58.3 & 58.3 \\
\hline & More than 10 years at school & 15 & 41.7 & 41.7 & 100.0 \\
\hline
\end{tabular}


Figure 22: Percentage of have been at the school 10 years or more.

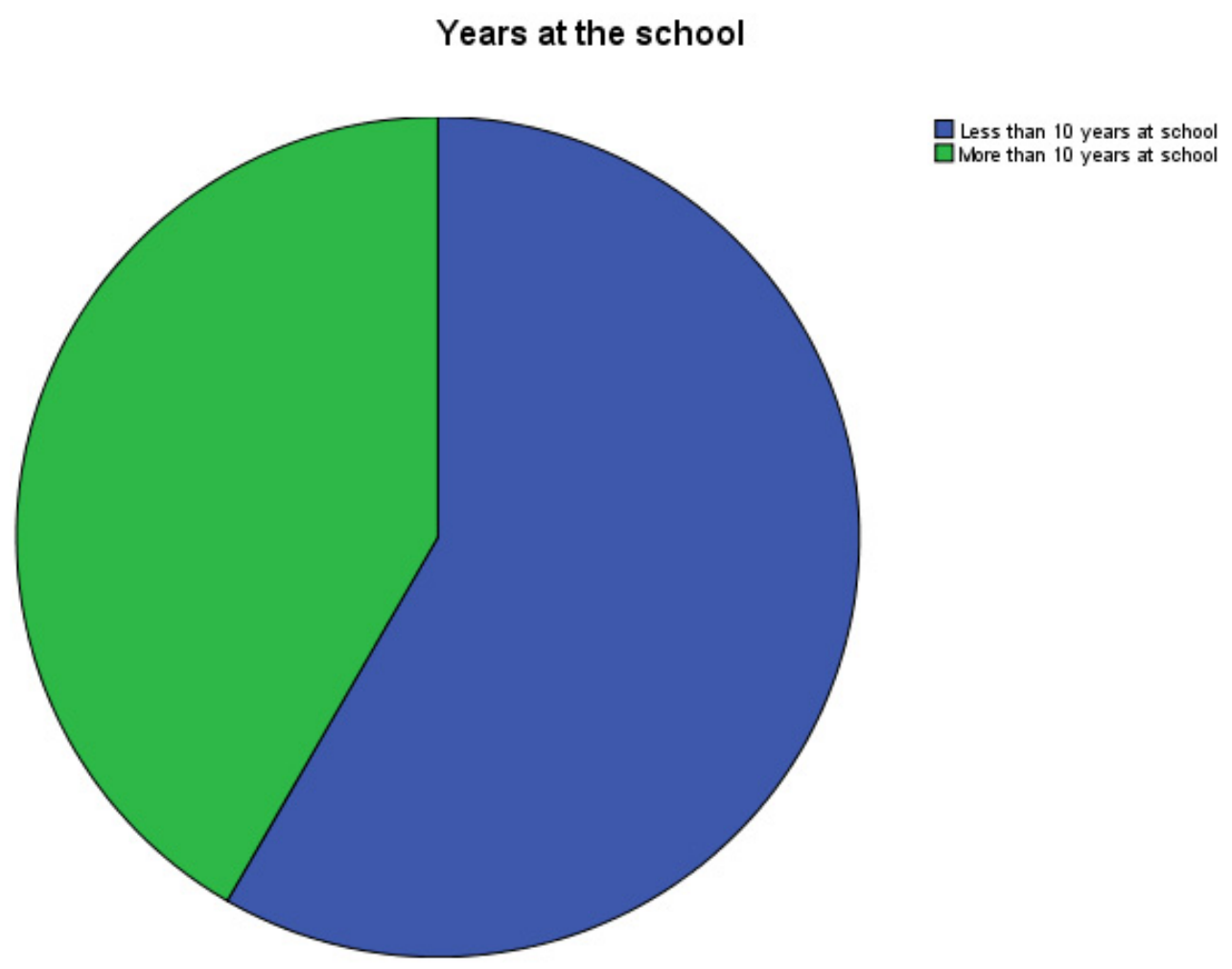

The frequency chart reveals that $41.7 \%$ of the teachers have been at this school for at least 10 years and were given the opportunity to take part in the initial survey (see Table 32 and Figure 22). The initial survey had a high rate of return, so it was likely that many of these teachers did participate in the survey and now were given the 2007 version of the survey. While this cannot be considered an exact longitudinal study matching the same participants, it does show a good representation of the school remains the same.

\section{Comparison of Two Sets of Data from 1997 and 2007 Survey}

Many of the same questions were asked in the 1997 and 2007 survey. Looking at the scores from the two surveys and comparing them provided insight into how much the school has changed in the past ten years. The only questions that were compared here 
were the ones addressed in the first study since that was the only data available to compare.

Computer knowledge vs. computer anxiety: compare results from two surveys.

Regression coefficients from the 1997 and 2007 survey were compared to see if the slope has changed.

1997 Survey: $r^{2}=-.531$

2007 Survey: $r^{2}=-.689$

There was a negative correlation in both studies, but there was a stronger correlation between computer knowledge and computer anxiety in the 2007 survey than the 1997 survey. It shows the continued importance of providing opportunities to increase computer knowledge will have a potential impact on the anxiety level.

Does computer anxiety affect the willingness to adopt technology: compare results for two surveys. Compare means from select survey questions 9 (1997-2007) Question 9 I Comparison: "All classrooms should be equipped with computers." 1997 Mean 3.58

2007 Mean 3.31

The chart shows a side by side comparison of descriptive statistics for the two years. Following is the frequency charts from both studies and comparison pie charts to show the differences in responses from the two different times. 
Table 33

Frequency : Question 9 I (Computers in Classrooms) (1997)

\begin{tabular}{|l|l|r|r|r|r|}
\hline \multicolumn{6}{|c|}{ All classrooms should be equipped with computer (1997) } \\
\hline \multirow{4}{*}{} & & Frequency & Percent & Valid Percent & \multicolumn{2}{c|}{$\begin{array}{c}\text { Cumulative } \\
\text { Percent }\end{array}$} \\
\hline \multirow{2}{*}{ Valid } & 1 Strongly Disagree & 0 & 0 & 0 & 0 \\
\cline { 2 - 6 } & 2 Disagree & 3 & 12.5 & 12.5 & 12.5 \\
\cline { 2 - 6 } & 3 Agree & 4 & 16.7 & 16.7 & 29.2 \\
\cline { 2 - 6 } & 4 Strongly Agree & 17 & 70.8 & 70.8 & 100.0 \\
\hline
\end{tabular}

Table 34

Frequency: Question 9 I (Computers in Classrooms) (2007)

\begin{tabular}{|l|l|r|r|r|r|}
\hline \multicolumn{6}{|c|}{ All classrooms should be equipped with computers (2007) } \\
\hline \multirow{5}{*}{ Valid } & Frequency & Percent & Valid Percent & \multicolumn{2}{c|}{$\begin{array}{c}\text { Cumulative } \\
\text { Percent }\end{array}$} \\
\cline { 2 - 7 } & 1 Strongly Disagree & 2 & 5.6 & 5.6 & 5.6 \\
\cline { 2 - 7 } & 2 Disagree & 3 & 8.3 & 8.3 & 13.9 \\
\cline { 2 - 6 } & 3 Agree & 13 & 36.1 & 36.1 & 50.0 \\
\cline { 2 - 6 } & 4 Strongly Agree & 18 & 50.0 & 50.0 & 100.0 \\
\hline
\end{tabular}


Figure 23 and Figure 24: Comparison figures of 1997 and 2007 for question 9 I

(Computers in Classrooms).

All classrooms should be equipped with computer: 1997

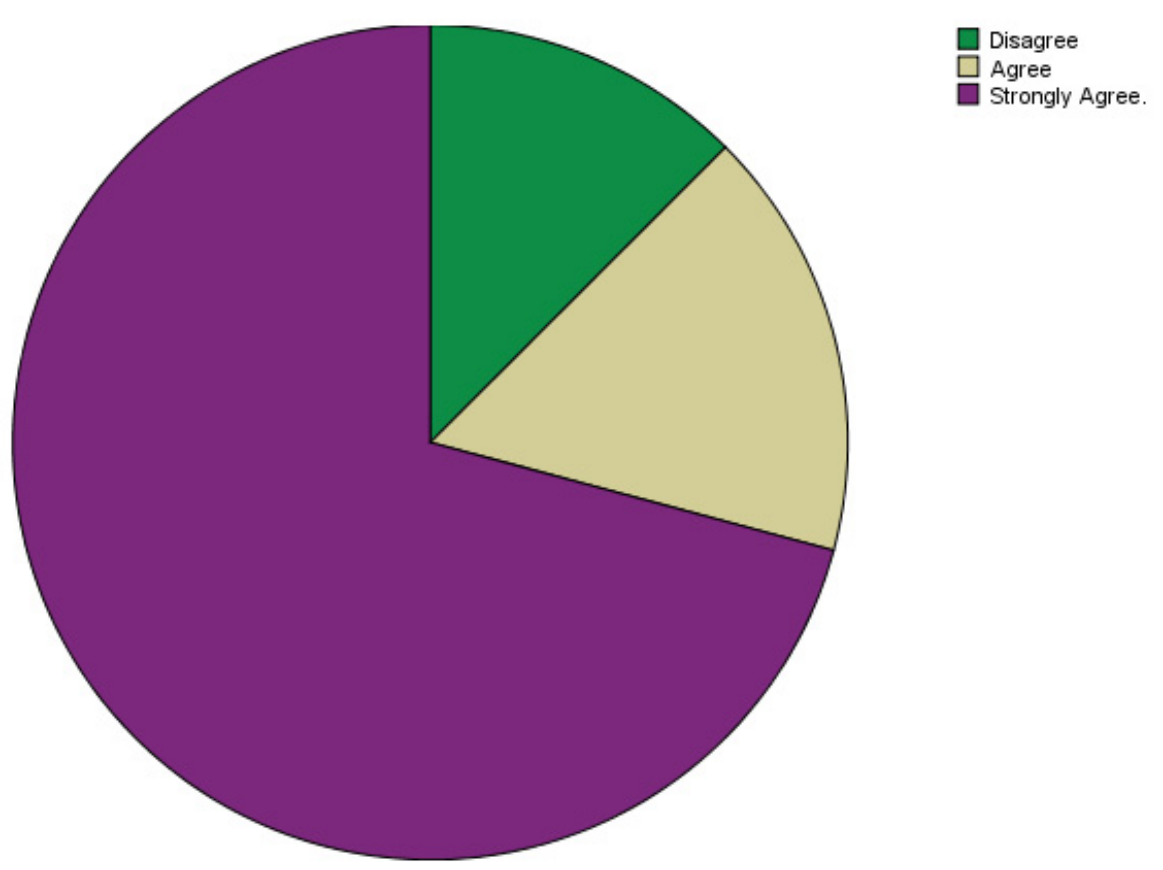

All classrooms should be equipped with computers: 2007

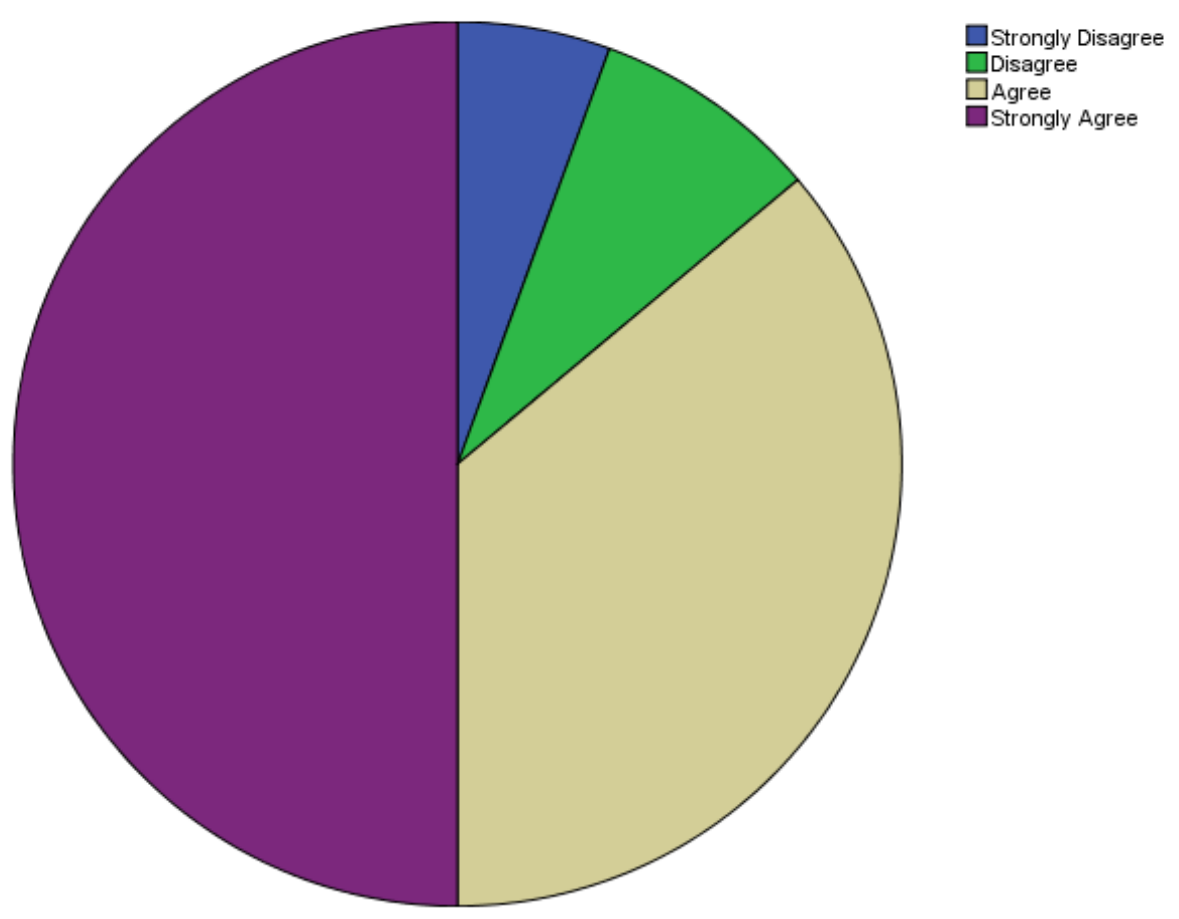


These charts show that in 1997 a larger percentage of teachers (70.8\%) strongly agreed that all classrooms should be equipped with computers compared with the 2007 survey (50\%) (see Tables 33 and 34). Also, it is interesting to note that no teachers selected "Strongly Disagree" in 1997 and 5.6\% of the teachers said that in 2007. Looking at the median scores for the two different years, the median was a high 4.0 in 1997 and a lower 3.5 in 2007. While this was not an exact population comparison due to some differences in teachers, it shows that as a whole the population was less enthusiastic about having computers in the classroom in 2007, than they were in 1997. Yet, that does not mean that the population as a whole was against having computer by any means. It was clear that $86.1 \%$ of the 2007 population still "agree" or "strongly agree" that computers should be in the classroom (see Table 33 and Figure 23 for 1997 and Table 34 and Figure 24 for 2007).

All students should use the Internet as part of the curriculum: compare results of two surveys. Comparison of means for Question $9 \mathrm{~J}$ from 1997 and 2007: “All students should use the Internet as part of the curriculum for instruction, learning, and research."

Mean 1997- 3.58

Mean $2007-2.92$ 
Table 35

Frequency: Question 9 J (All Students should use Internet): 1997

\begin{tabular}{|l|l|r|r|r|r|}
\hline \multicolumn{6}{|c|}{$\begin{array}{c}\text { All students should use the Internet as part of the curriculum for } \\
\text { instruction, learning, and research (1997) }\end{array}$} \\
\hline & & Frequency & Percent & Valid Percent & $\begin{array}{c}\text { Cumulative } \\
\text { Percent }\end{array}$ \\
\hline \multirow{4}{*}{ Valid } & 1 Strongly Disagree & 0 & 0 & 0 & 0 \\
\hline & 2 Disagree & 1 & 4.2 & 4.2 & 4.2 \\
\cline { 2 - 7 } & 3 Agree & 8 & 33.3 & 33.3 & 37.5 \\
\cline { 2 - 6 } & 4 Strongly Agree & 15 & 62.5 & 62.5 & 100.0 \\
\hline
\end{tabular}

Table 36

Frequency: Question 9 J (All Students should use Internet): 2007

\begin{tabular}{|c|c|c|c|c|c|}
\hline \multicolumn{6}{|c|}{$\begin{array}{l}\text { All students should use the Internet as part of the curriculum for instruction, } \\
\text { learning and research (2007) }\end{array}$} \\
\hline & & Frequency & Percent & Valid Percent & $\begin{array}{l}\text { Cumulative } \\
\text { Percent }\end{array}$ \\
\hline \multirow[t]{4}{*}{ Valid } & 1 Strongly Disagree & 2 & 5.6 & 5.6 & 5.6 \\
\hline & 2 Disagree & 9 & 25.0 & 25.0 & 30.6 \\
\hline & 3 Agree & 15 & 41.7 & 41.7 & 72.2 \\
\hline & 4 Strongly Agree & 10 & 27.8 & 27.8 & 100.0 \\
\hline
\end{tabular}


Figure 25 and Figure 26: Comparison figures of 1997 and 2007 for question 9 J

(Students should use Internet).

All students should use the Internet as part of the curriculum for instruction, learning, and research (1997)
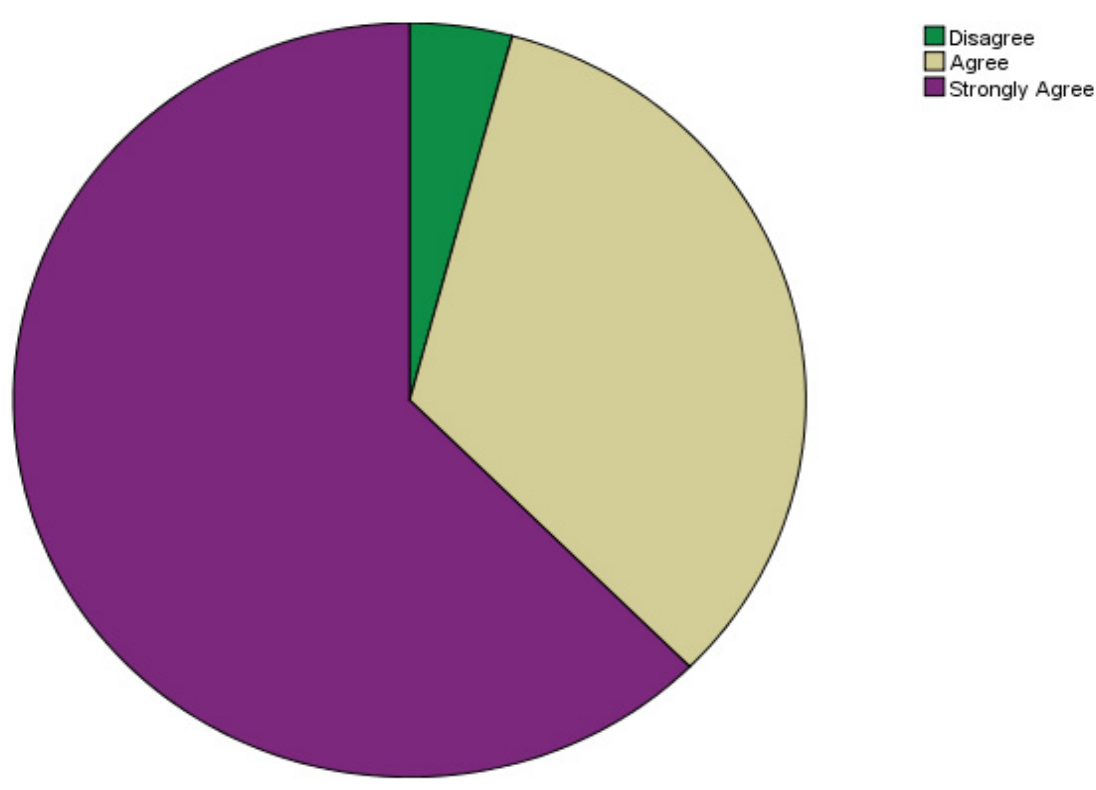

All students should use the Internet as part of the curriculum for instruction, learning and research.(2007)
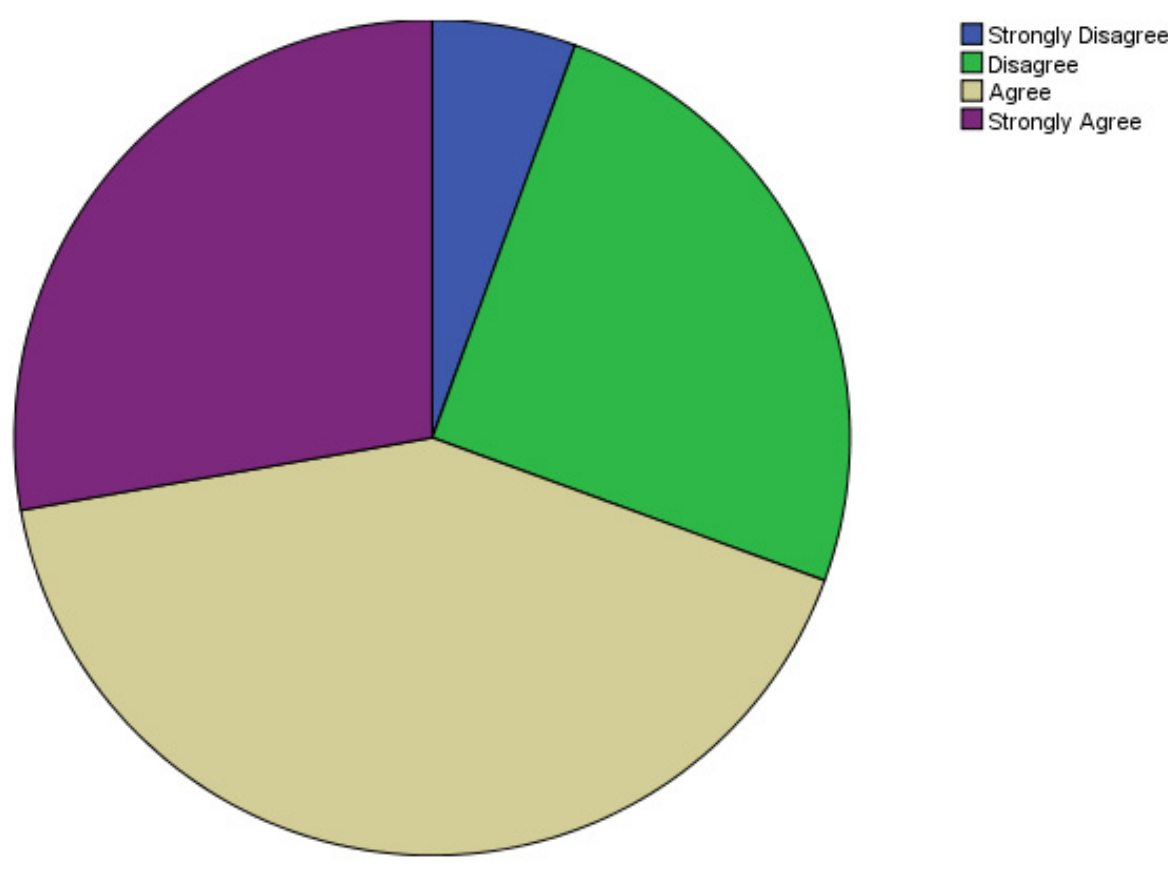
The analysis of this question over the two time periods show that the teachers felt more strongly that the students should learn to use the Internet in 1997 (with 62.5\% strongly agreeing and $33.3 \%$ agreeing - total $95.8 \%$ ). In 2007 only $27.8 \%$ strongly agreeing and $41.7 \%$ agreed- total $69.5 \%$ ). It is also notable that no teachers responded "strongly disagree" in 1997, and 2 teachers responded that way in this survey. One explanation for this could be that the dangers of the Internet were not as widespread or widely known in 1997 as they were in 2007. (see Table 35 and Figure 25 for 1997 and Table 36 and Figure 26 for 2007).

Question 9 K Comparison: "All teachers should use the Internet for communications, instruction and research."

Mean 1997: 3.52

Mean 2007: 2.97

Table 37

Descriptive Comparison of Question $9 K$ (All Teachers should Use Internet)

\begin{tabular}{|l|r|rr|}
\hline \multicolumn{3}{|c|}{ Comparison of Question 9 K } \\
\hline & $\begin{array}{r}\text { All teachers should learn } \\
\text { how to use the Internet } \\
\text { for communications, } \\
\text { instruction development, } \\
\text { and research.(2007) }\end{array}$ & $\begin{array}{c}\text { All teachers should learn } \\
\text { how to use the Internet for } \\
\text { communication, instruction } \\
\text { development, and } \\
\text { research (1997) }\end{array}$ \\
\hline Mean & 2.97 & \multicolumn{2}{|c|}{3.52} \\
\hline Median & 3.00 & 4.00 \\
\hline Mode & 3 & 2 \\
\hline Range & 3 & 4 \\
\hline
\end{tabular}


Table 38

Frequency: Question 9 K (All Teachers should Use Internet) (1997)

All Teachers should use the Internet for communications, instruction development and research (1997)

\begin{tabular}{|l|l|r|r|r|r|}
\hline & & & & & \multicolumn{2}{c|}{$\begin{array}{c}\text { Cumulative } \\
\text { Percent }\end{array}$} \\
\hline \multirow{3}{*}{ Valid } & Frequency & Percent & Valid Percent & 0 \\
\cline { 2 - 6 } & 1 Strongly Disagree & 0 & 0 & 0 & 8.3 \\
\cline { 2 - 6 } & 3 Disagree & 2 & 8.3 & 8.3 & 41.7 \\
\cline { 2 - 6 } & 4 Agree & 8 & 33.3 & 33.3 & 100.0 \\
\hline
\end{tabular}

Table 39

Frequency: Question 9 K (All Teachers should use Internet) (2007)

\begin{tabular}{|c|c|c|c|c|c|}
\hline \multicolumn{6}{|c|}{$\begin{array}{l}\text { All teachers should use the Internet for communications, instruction } \\
\text { development, and research (2007). }\end{array}$} \\
\hline & & Frequency & Percent & Valid Percent & $\begin{array}{l}\text { Cumulative } \\
\text { Percent }\end{array}$ \\
\hline \multirow[t]{4}{*}{ Valid } & 1 Strongly Disagree & 2 & 5.6 & 5.6 & 5.6 \\
\hline & 2 Disagree & 9 & 25.0 & 25.0 & 30.6 \\
\hline & 3 Agree & 13 & 36.1 & 36.1 & 66.7 \\
\hline & 4 Strongly Agree & 12 & 33.3 & 33.3 & 100.0 \\
\hline
\end{tabular}


Figure 27 and Figure 28: Comparison figures of 1997 and 2007 for question $9 \mathrm{~K}$

(Teachers should use Internet).

All teachers should use the Internet for communications, instruction development, and research (1997)

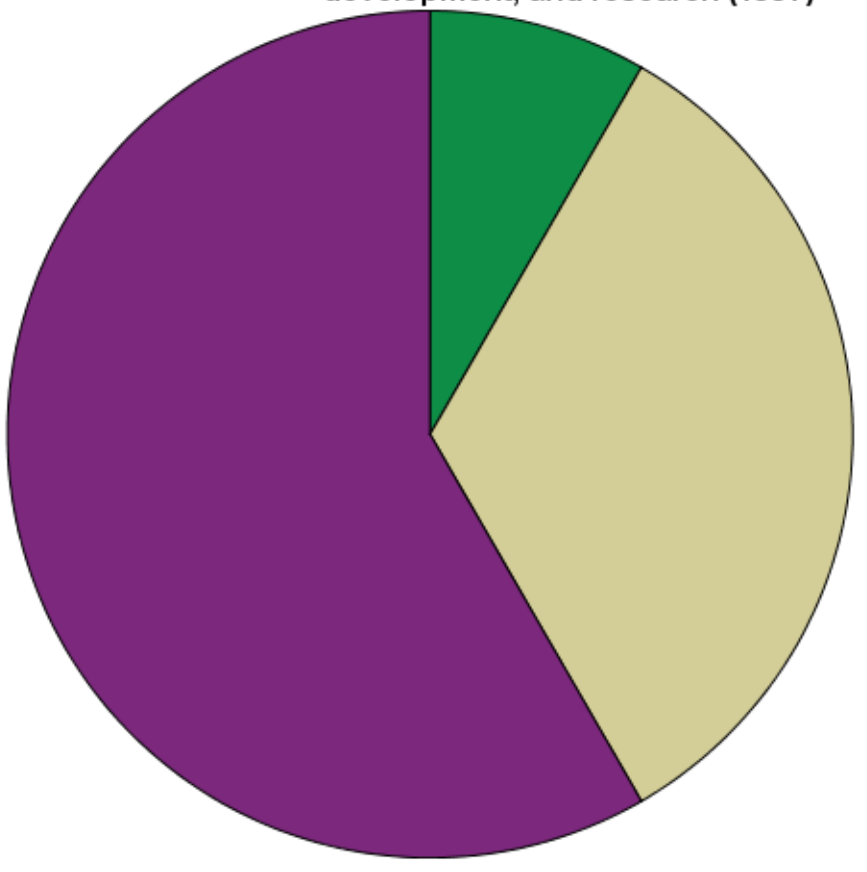

$\square 2$-Disagree

$\square 3$ - Agree

All teachers should use the Internet for communications, instruction development, and research (2007)

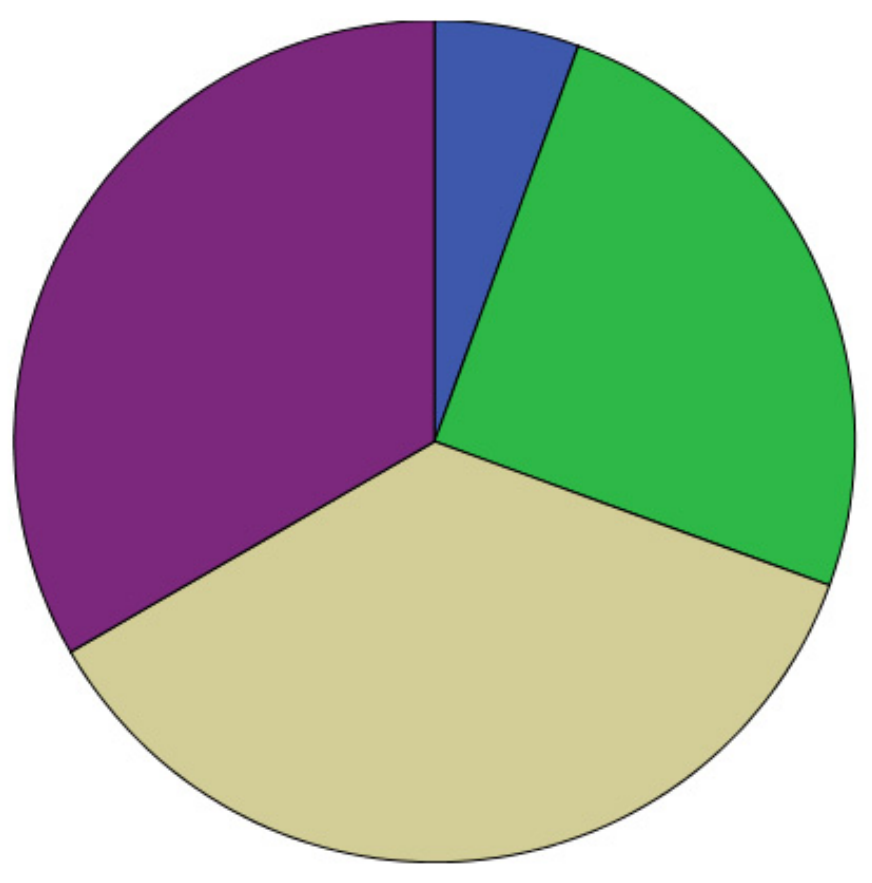

$\square$ Strongly Disagree

$\square$ Disagree

$\square$ Agree

Strongly Agree 
In $1997(58.3 \%)$ of the teachers said that they strongly agree that teachers should use the Internet. In 2007 , only $33.3 \%$ of the teachers responded this way. There was a decline the overall number of people who "agree or strongly agree" in 2007 (69.7\%) vs. 1997 when $91.6 \%$ of the teachers "agree or strongly agree". Teachers in 1997 had very limited Internet training at the time and there was not even Internet connection at the school, so they were answering the question based on the potential without actually using the technology. Teachers in 2007 had been using the Internet and may have a different perspective, especially since more Internet and technology requirements are being mandated (see Table 38 and Figure 27 for 1997 and Table 39 and Figure 28 for 2007).

Computer use at home means: compare results of two surveys. Using comparisons of means for computer use at home in 1997 and 2007 (see Table 30).

Question 4 Comparisons: "How often do you use computers outside of school?" Mean $1997=2.79$

Mean $2007=3.94$ 
Table 40

Descriptive Comparison of Question 4 (Home Use of Computers)

\begin{tabular}{|l|r|r|}
\hline \multicolumn{2}{|c|}{ Comparison of question 4 in 1997 and 2007} \\
\hline & $\begin{array}{c}\text { How Often do } \\
\text { you use } \\
\text { computer outside } \\
\text { of school? } \\
(1997)\end{array}$ & $\begin{array}{c}\text { How Often do } \\
\text { you use } \\
\text { computers } \\
\text { outside of } \\
\text { school? (2007) }\end{array}$ \\
\hline Mean & 2.79 & 3.94 \\
\hline Median & 3.00 & 4.00 \\
\hline Mode & 3 & 4 \\
\hline
\end{tabular}

Key

\begin{tabular}{|l|l|}
\hline 1 & Never \\
\hline 2 & Seldom \\
\hline 3 & Somewhat \\
\hline 4 & Often \\
\hline 5 & Very Often \\
\hline
\end{tabular}


Figure 29 and Figure 30: Comparison graphs of computer use in 1997 and 2007.
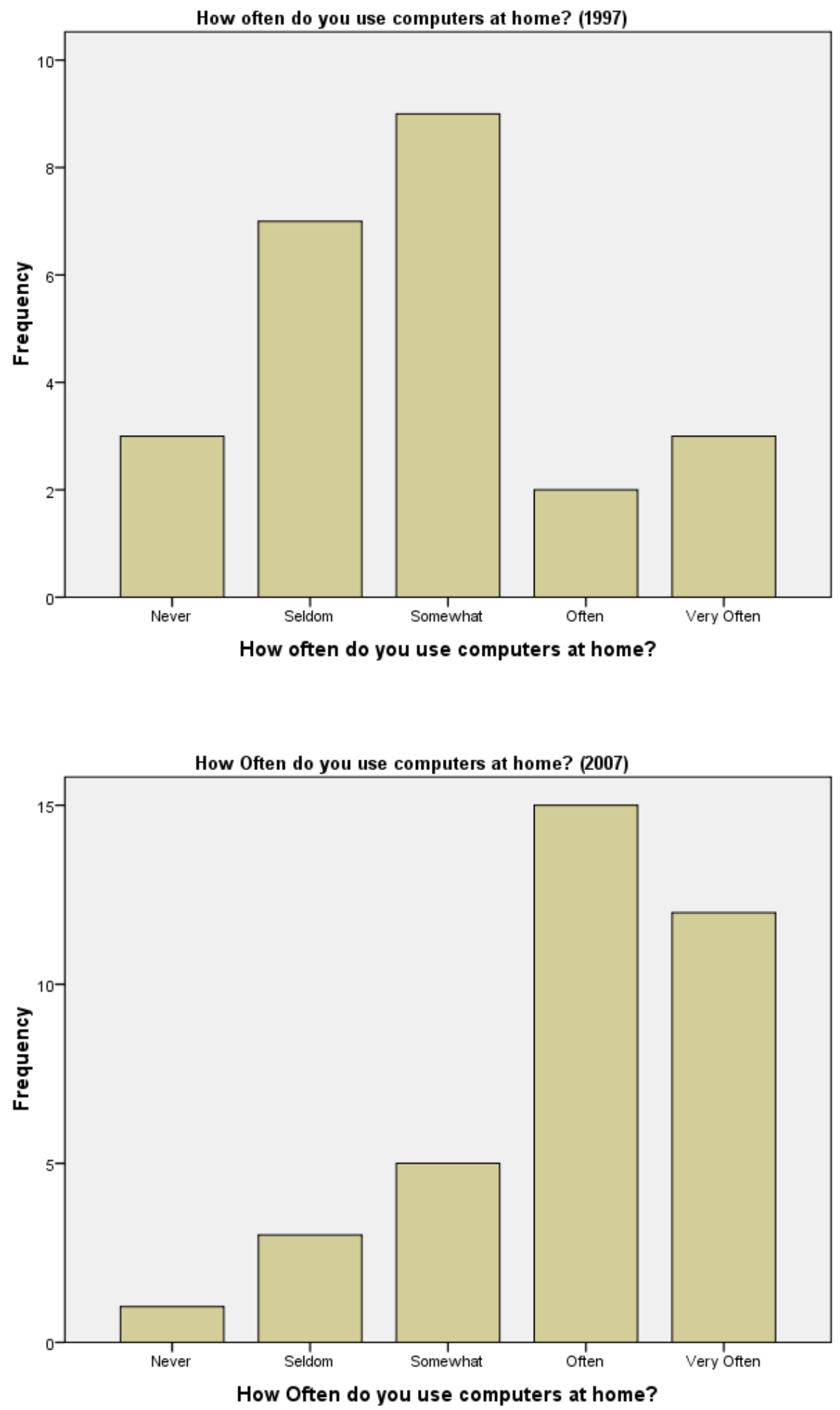
(See Figure 29 and 30) This question compares the use of computers outside of school as described in question 4. Comparing the two graphs clearly shows that the teachers are using the computer much more often at home in 2007 than in 1997. The means for the computer at home also show much higher means for 2007 (3.94) than in 1997 (2.79). Using the computer use outside of school versus comparing school use helps to remove the mandatory factor of computer use at school. Teachers using computers outside of school are feeling comfortable using them and have a higher mean.

Knowledge of computer technologies: compare results of two surveys. Compare means and figures from 1997 and 2007 results.

Question 1: "How would your rate your knowledge of computer technologies?"

$$
\text { Mean } 1997=3.042
$$

Mean $2007=3.40$ 
Figure 31 and Figure 32: Comparison figures of computer knowledge for 1997 and 2007.

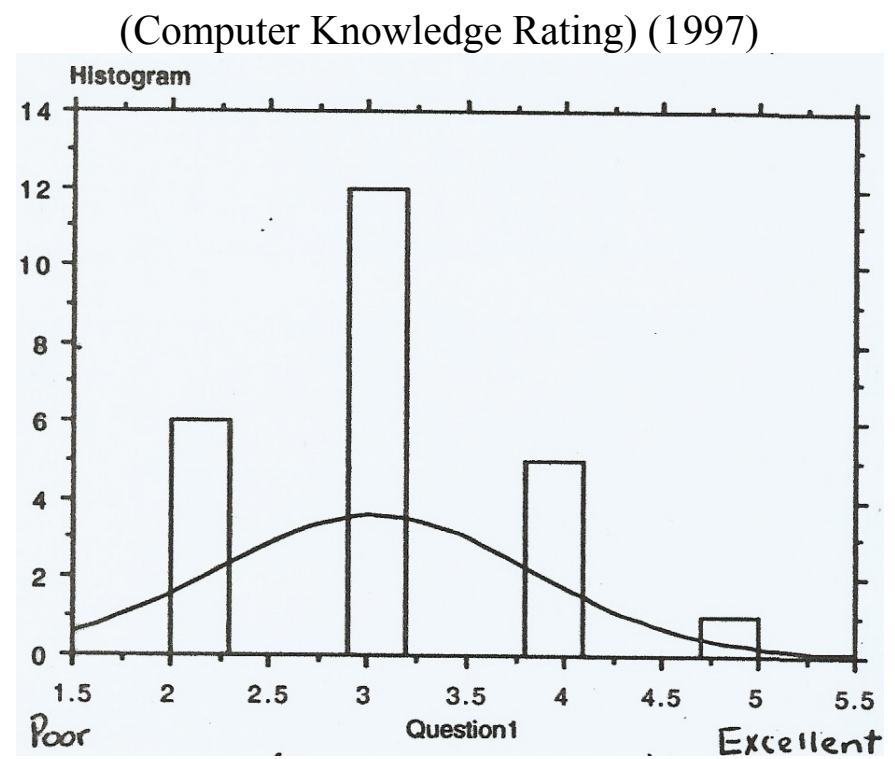

Indicate the level of training you have received on computers as an instructional tool?

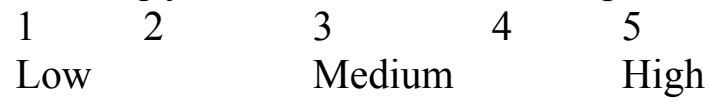

Mean $=3.042$

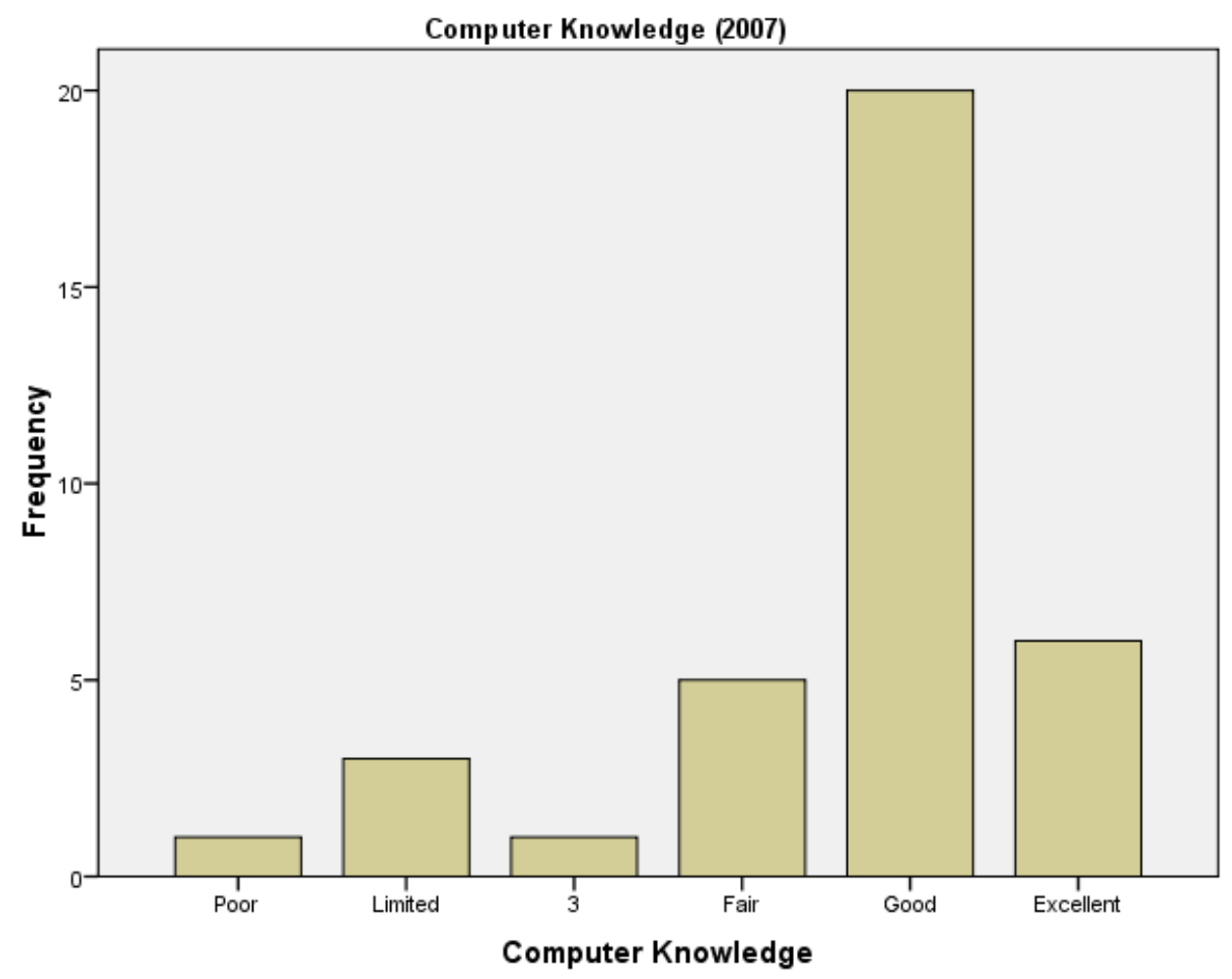

Mean $=3.40$ 
(See Figure 31 and Figure 32) Looking at these two graphs and comparing computer knowledge in 1997 and computer knowledge in 2007 clearly shows that the teachers feel more knowledgeable about computer training in 2007. The mean for 2007 was 3.40, compared to the 1997 mean of 3.04. Also a larger percentage of teachers felt they had limited knowledge in 1997 compared to 2007. This concludes that most teachers feel they have gained a "good" amount of knowledge about computers over the past 10 years.

Amount of computer training: compare results of two surveys. Compare means and figures from 1997 and 2007.

Compare Question 6: "Indicate the level of training you have received on computers as an instructional tool."

$$
\begin{aligned}
& \text { Mean } 1997=2.54 \\
& \text { Mean } 2007=3.74
\end{aligned}
$$


Figure 33 and Figure 34: Comparison figures or computer training for 1997 and 2007.
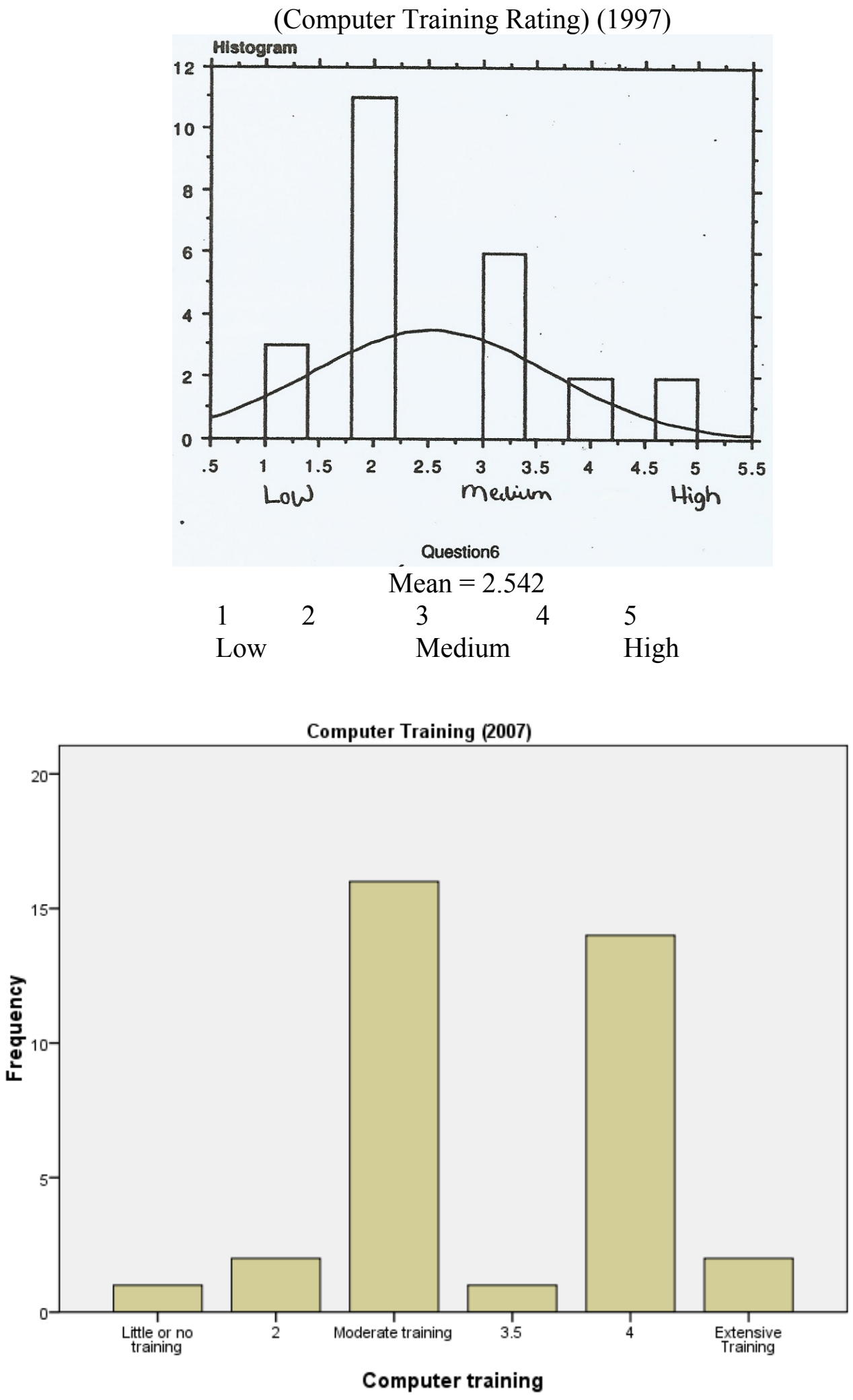

Mean $=3.74$ 
(See Figures 33 and 34) This analysis also shows that there has been significantly more training in 2007 (Mean 3.74) compared to the level of training in 1997 (Mean 2.54). The most frequent response was a (2) in 1997, and is a (3) in 2007. Also many more people responded (4) in the second study versus the first study. Overall, the teachers have had a higher level of training in 2007 than in 1997.

Comparing these results to the results for computer knowledge showed that there are some gains in knowledge over the past ten years. Knowing that there is a correlation between computer training and computer knowledge, it could be concluded that at least some of the gains in knowledge were gained by increases in computer training levels. Which makes sense to say that by having more training equals having more knowledge in that area, a basic principle in education.

Knowledge of Internet applications: compare results from the two surveys. Compare means and figures from 1997 and 2007.

Question 2: "How would you rate you knowledge of the use of Internet applications".

Mean $1997=2.63$

Mean $2007=3.83$ 
Figure 35 and Figure 36: Comparison figures of Internet knowledge for 1997 and 2007.

Knowledge of telecommunications/Internet (1997)

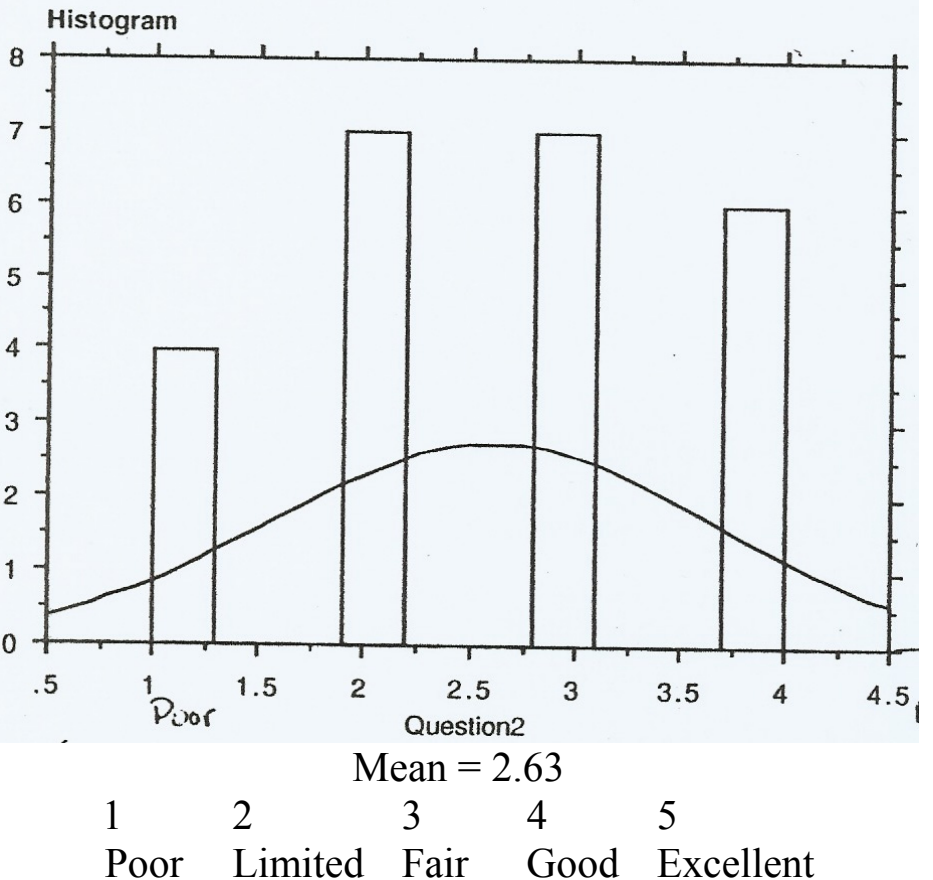

Knowledge of Internet Applications (2007)

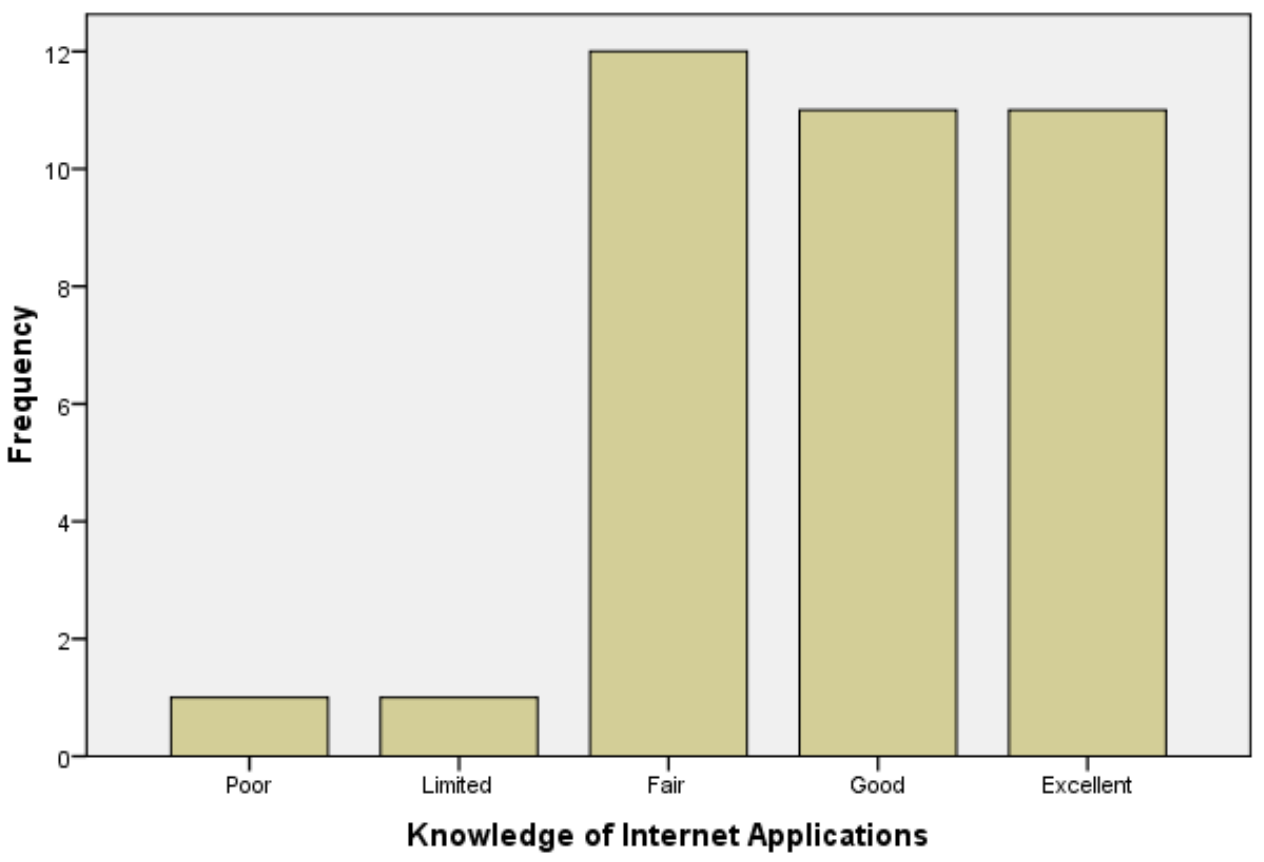

Mean $=3.86$ 
(See Figures 35 and 36) Looking at the knowledge of Internet means from 1997 (2.63) and from 2007 (3.86), it is clear that the teachers are much more knowledgeable about using the Internet in the latter study. The mean from the first study was closer to "limited" training with no participants selecting "excellent". The 2007 study showed 11 people chose "excellent" in the second study. This data shows that the teachers in 2007 have a much higher level of knowledge of using Internet application than the group did in 1997.

Level of Internet training: compare results from the two surveys. Compare means and figures from 1997 and 2007.

Question 7: "How much training have you received on using the Internet as an instructional tool?"

Mean 1997: 2.33

Mean 2007: 3.15 
Figure 37 and Figure 38: Comparison figures of Internet training for 1997 and 2007.

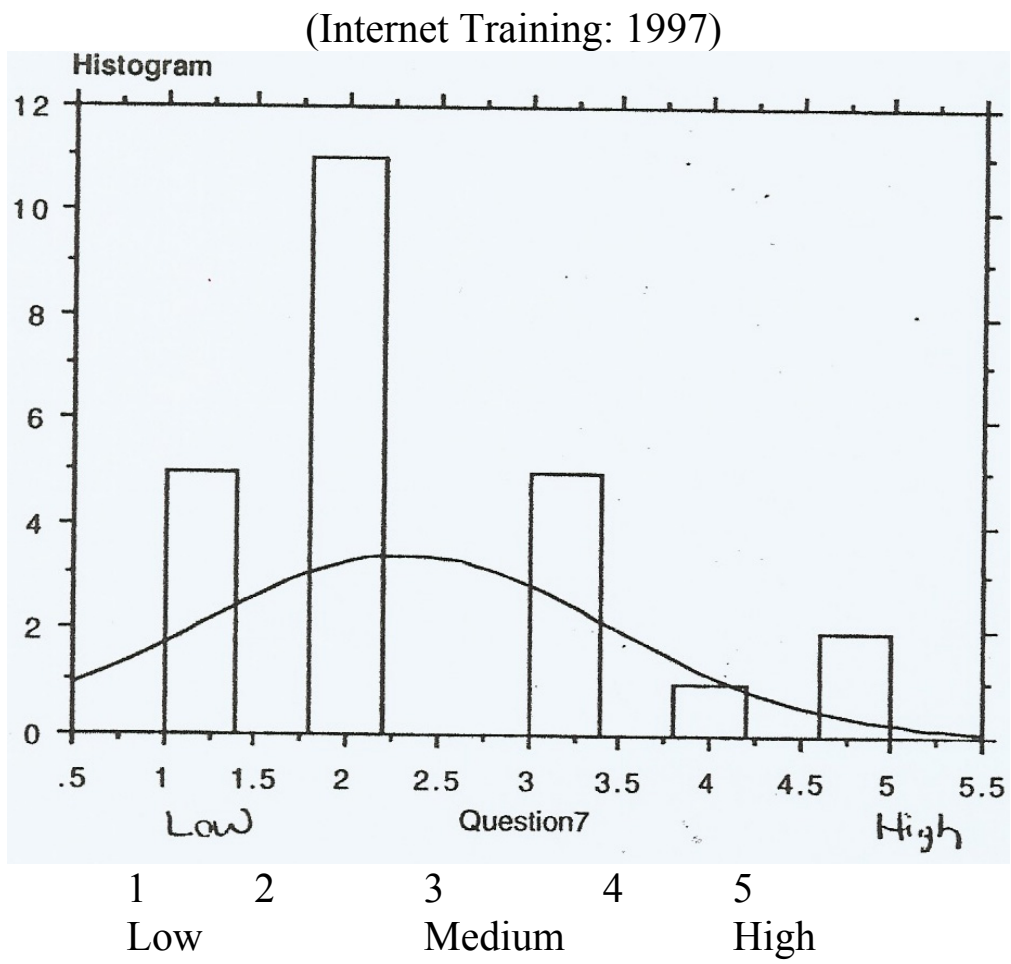

Mean $=2.33$

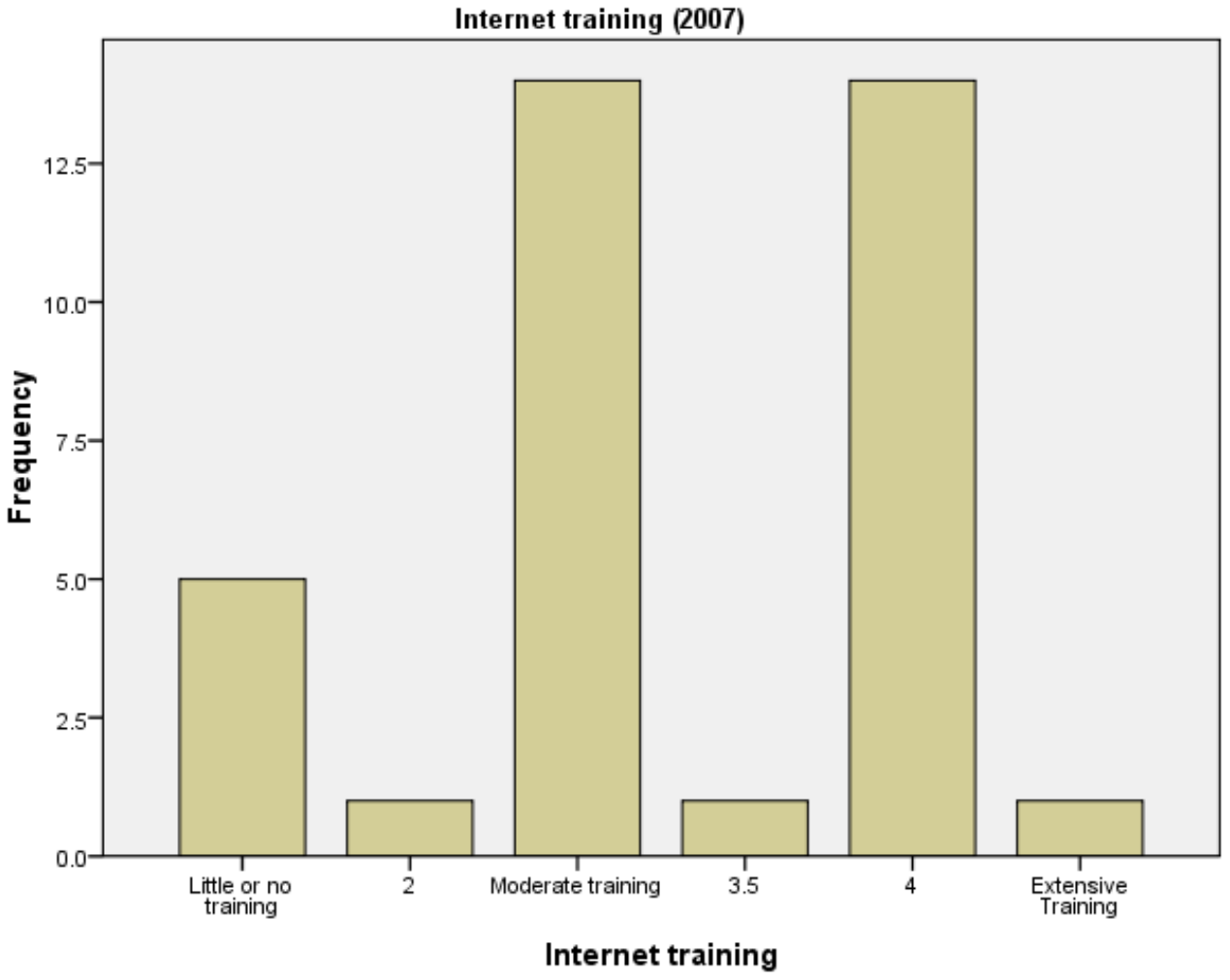

Mean $=3.15$ 
(See Figures 37 and 38) In 2007, the teachers as a whole had a mean score of 3.15, which is better than a moderate level of training. The 1997 survey showed a lower mean of 2.33, being a little over "little or no training". Only one teacher had a score of 4 in the 1997 survey, and 14 teachers had a score of 4 in 2007 . This data shows that the teachers have had more training on Internet in 2007 than they did in 1997.

Looking at the teachers' knowledge of the Internet and the level of training in 1997, it appeared they have a lower level of knowledge and also a low level of training. By looking at the 2007 survey and comparing the teachers' knowledge of the Internet and the level of training, it appear that the teachers feel pretty confident in their knowledge of using the Internet even though they only had moderate training. This would conclude that while the teachers had some training, much of their knowledge about the Internet was not gained through training (due to the lesser training level). One explanation to this discrepancy would be that the teachers may have been self-taught when using the Internet.

Anxiety scores: compare scores from two surveys. Compare means of anxiety scores from 1997 and 2007.

Question 5: "How do you assess your current comfort level of using computer and computer technologies?”

$$
\begin{gathered}
\text { Mean } 1997=2.79 \\
\text { Mean } 2007=2.19 \\
1=\text { Low anxiety } \quad 5=\text { High Anxiety }
\end{gathered}
$$


Comparing the two means based on the self-reported comfort/anxiety level the teachers show they have a lower mean (less anxiety) in 2007 versus 1997. Looking at the anxiety level from question 5, it can be concluded that the anxiety level was lower in 2007 than it was in 1997. It is probably noteworthy that the causes for the anxiety have changed over the years as expectations have changed and training has occurred. Teachers in 1997 were anxious about using the computer at all and the basic principles like e-mail and searching the Internet were stressful for them. Now these principles are well mastered by a majority of the teachers (as discussed in the later section on technology usage). The new anxiety comes from the new programs, software, and devices (like the whiteboard), as discussed in the interviews.

The overall anxiety level just shifts to the next level as the teachers feel comfortable and master one thing and move to the next. This is why continued training and support is important, to keep the teachers confident as they learn more about using the technology.

\section{Results for Research Question 2}

Research Question 2: Compare the differences in the technology infrastructure at this school, including the changes in support, physical changes and training in 1997 and 2007.

Training and support. Training is an important aspect in implementing technology in the schools. Several questions in the survey/interview addressed this topic.

Open-ended Survey Question 15 and Interview question 3: "Discuss the technology training the faculty has received. Has it been helpful and meaningful in the integration of computers in your curriculum?" 
Table 41

Analysis for Question 15/ Interview Question 3 (Training Received)

\begin{tabular}{|l|c|}
\hline \multicolumn{1}{|c|}{ Response } & Number of teachers responding this way \\
\hline Don't Feel Adequately Trained & 13 \\
\hline Somewhat Trained & 5 \\
\hline Well Trained & 41 \\
\hline Not Enough Time & 4 \\
\hline
\end{tabular}

Responses to this question showed a wide range of training levels. Training has been addressed several ways. One teacher talked about where she got her training, "I have taken several computer classes through the county offerings." Another teacher felt the technology contact (who has two periods a day to meet the technology needs of the school) at the school was helpful in training, "With the addition of a computer assistant, my questions are answered quickly so I can use the technology in my classroom.” A third teacher responded, "Most of my training has been self-taught." One teacher discussed the training she received in college and the training course she received upon entering the school system (see Table 41).

There were various perceptions of how much training they have received. One teacher said, "Yes, we have had extensive training". While another teacher said "I am sure I've been trained, however I don't use the training enough to feel comfortable." Another teacher responded to the open-ended survey question by saying "I feel comfortable with most activities, I am not trained with whiteboards, but am looking forward to using them." 
Time also played a factor in training. One teacher responded that there was "Not enough time in the day to prepare (for technology)." Another teacher suggested that "having time to explore the use the computers would be beneficial." One teacher who was eager to learn said that he takes training workshops "anytime there is anything offered." In the interview this teacher also said that while there is adequate training, he would like to see more training offered in a more spread-out manner. The training crammed in one long session is too much at one time. He would like to see follow-up on the training after the teachers get to try out what they learned. The third interviewee also reiterated this idea when she said "There is not enough training available and when you do get training they send you back in the classroom without any support. There is no time available to work with the technology." This teacher continued to say that she felt "so overwhelmed with posting grades and lesson plans that she did not have time for other things."

Support in using the technology and assistance in learning about the technology seems to be a big factor in the use of the technology. In an interview one teacher said there were so many new programs available and time is a factor in learning the new software and programs. She would like to see a teacher who is specifically trained in technology whose job would be to work these programs to assist the classroom teacher. With this approach, training would be more one-on-one with the teacher and the technology contact teacher would feel supported and gradually become more comfortable with using the technology on their own.

A teacher's response to this question sums up much of the training issue, "There is an attempt to train at the county level. What we really need is in-house, sustained 
training with a full-time technology integration specialist to provide training and support throughout the year and time in our day to plan for and use the technology."

This question shows that there still are a lot of teachers who would like to have more training and more time to learn to use the technology. Having support and help is also an influencing factor.

Also open-ended survey question 16 asked: "Is there any areas of technology about which you would like more training?"

Table 42 synthesizes the teachers' responses:

Table 42

Analysis of Question 16 (Training Needed)

\begin{tabular}{|l|c|}
\hline \multicolumn{1}{|c|}{$\begin{array}{c}\text { Technology in which teachers would like } \\
\text { more training }\end{array}$} & Number of teachers responding \\
blank)/ Want to self-teach & 8 \\
\hline Interactive Whiteboard & 7 \\
\hline Responded "Yes"/Any Training/New & \\
Software/All Programs & 4 \\
\hline Subject Specific/Finding Lesson & 11 \\
\hline Plans/Learning Strategies & 1 \\
\hline Video (Importing and Sound Editing) & 1 \\
\hline Virtual Learning & 1 \\
\hline Sites for Students & \\
\hline Blogs & \\
\hline
\end{tabular}




\begin{tabular}{|l|c|}
\hline Satellite & 1 \\
\hline United Streaming & TM \\
\hline Excel $^{\mathrm{TM}}$ & 1 \\
\hline
\end{tabular}

The area in which more teachers want training is the Interactive whiteboard, which make sense because the school just began getting these in their classrooms. From discussions with the Technology Contact teacher and the principal, seminars are being offered throughout the summer for teachers to learn more about the whiteboard and other technology. It is worth noting that a large number of responders (11) did not answer the question or stated that they did not want any more training. Eight people said "Yes" I need more training, "I feel I need more training in all of the programs we have available to us." The reasons for teachers not responding or answering no could vary. Possibly, the teacher' don't feel they have time for training, feel the training they receive is not in a format they prefer, or just didn't have an opinion when answering the survey (see Table 42).

Content specific training also received 4 responses. One teacher wrote that he wanted more training on "finding ways to use the computer for subject specific activities." Another teacher said she would like to find "musical programs and maybe drama and literature sites."

The following survey questions also address training:

Question 6: "How much training have you received in using the computer as an instructional tool?" 
Question 7: "How much training have you received in using the Internet as an instructional tool?"

Question 8: "How do you feel about the overall amount of instructional technology training you have received" 
Table 43

Frequency: Question 6: (Level of Computer Training) and Question 7 (Internet

\section{Training)}

\begin{tabular}{|c|c|c|c|c|c|}
\hline \multicolumn{6}{|c|}{ Computer Training: Survey Question 6} \\
\hline & & Frequency & Percent & Valid Percent & $\begin{array}{c}\text { Cumulative } \\
\text { Percent }\end{array}$ \\
\hline \multirow[t]{6}{*}{ Valid } & Little or no training & 1 & 2.8 & 2.8 & 2.8 \\
\hline & 2 & 2 & 5.6 & 5.6 & 8.3 \\
\hline & Moderate training & 16 & 44.4 & 44.4 & 52.8 \\
\hline & 3.5 & 1 & 2.8 & 2.8 & 55.6 \\
\hline & 4 & 14 & 38.9 & 38.9 & 94.4 \\
\hline & Extensive Training & 2 & 5.6 & 5.6 & 100.0 \\
\hline \multicolumn{6}{|c|}{ Internet training: Survey Question 7} \\
\hline & & Frequency & Percent & Valid Percent & $\begin{array}{c}\text { Cumulative } \\
\text { Percent }\end{array}$ \\
\hline \multirow[t]{6}{*}{ Valid } & Little or no training & 5 & 13.9 & 13.9 & 13.9 \\
\hline & 2 & 1 & 2.8 & 2.8 & 16.7 \\
\hline & Moderate training & 14 & 38.9 & 38.9 & 55.6 \\
\hline & 3.5 & 1 & 2.8 & 2.8 & 58.3 \\
\hline & 4 & 14 & 38.9 & 38.9 & 97.2 \\
\hline & Extensive Training & 1 & 2.8 & 2.8 & 100.0 \\
\hline
\end{tabular}


Table 44

Frequency: Question 8 (Overall Technology Instruction Received)

\begin{tabular}{|c|c|c|c|c|c|}
\hline & & Frequency & Percent & Valid Percent & $\begin{array}{c}\text { Cumulative } \\
\text { Percent }\end{array}$ \\
\hline \multirow[t]{6}{*}{ Valid } & Less Training Needed & 1 & 2.8 & 2.8 & 2.8 \\
\hline & 2 & 2 & 5.6 & 5.6 & 8.3 \\
\hline & 2.5 & 1 & 2.8 & 2.8 & 11.1 \\
\hline & Moderate Training & 14 & 38.9 & 38.9 & 50.0 \\
\hline & 4 & 16 & 44.4 & 44.4 & 94.4 \\
\hline & Extensive Training & 2 & 5.6 & 5.6 & 100.0 \\
\hline
\end{tabular}

From looking at the data from all three sources (Table 43 and 44), it appears that teachers have received at least moderate or better training in the Internet and computers according to the survey questions $6,7,8$. Yet in the open-ended question, 13 of the participants said they don't feel adequately trained and 11 said they were well-trained. This shows that while they may have received training, they don't feel they were trained in a way to feel confident using the technology in the classrooms.

The mandated programs such as Edline ${ }^{\mathrm{TM}}$ and Gradequick are extensively used, as would be expected with the mandate. The teachers are also embracing the technology that assists them in lesson planning and curriculum development. E-mail has become an important communication tool that they are regularly using. Teachers at this school did feel that time was a constraint in having to learn and implement new technology. They want specific training on the whiteboard and many of them want specialized training on 
specific software or devices to help meet the needs of their class. Teachers also want more support to help them better utilize the software.

Document analysis: changes in physical infrastructure from 1996-2007. Review infrastructure survey from 1996 (Appendix D) and 2007 (Appendix E) to look for changes in hardware, software, wiring, connectivity and training.

Table 45

Summary of Relevant Infrastructure Changes: Document Analysis

\begin{tabular}{|c|c|}
\hline 1996 Infrastructure & 2007 Infrastructure \\
\hline $\begin{array}{l}\text { Internet Connection: Wired for } 1 \mathrm{~T} 1 \text { line } \\
\text { not connected yet. No connection at this } \\
\text { time. }\end{array}$ & $\begin{array}{l}\text { Internet Connection: } 2 \mathrm{~T} 1 \text { Lines }- \text { Internet } \\
\text { operational in all classroom and wireless } \\
\text { connection available. }\end{array}$ \\
\hline Data transmission: In office only & $\begin{array}{l}\text { Data transmission: Throughout school, } \\
\text { online grade books, e-mail. }\end{array}$ \\
\hline $\begin{array}{l}\text { Network }-2 \text { servers running library and } \\
\text { computer lab. }\end{array}$ & $\begin{array}{l}\text { Network - Local Area Network running off } \\
\text { server with school-wide access. }\end{array}$ \\
\hline Security - unsure & $\begin{array}{l}\text { Security - Cameras throughout hallways, } \\
\text { locked doors with magnetic key entry, } \\
\text { closed circuit television and intercom to } \\
\text { front door, fire alarms automatically call } \\
\text { fire department. }\end{array}$ \\
\hline $\begin{array}{l}\text { Computers: } 30 \text { computers in lab setting } \\
\text { and several Macintosh in other locations }\end{array}$ & $\begin{array}{l}\text { Computers: } 240 \text { Computers in school with } \\
2 \text { labs housing } 30 \text { each, wireless mobile }\end{array}$ \\
\hline
\end{tabular}




\begin{tabular}{|c|c|}
\hline & lab, library lab. \\
\hline Hard drive capabilities: $8 \mathrm{MB}$ & $\begin{array}{l}\text { Hard drive capabilities: } 2.0-3.0 \mathrm{GHz} \\
\text { (That would be up to } 3,000,000,000 \mathrm{MB} \text { ) }\end{array}$ \\
\hline CD-ROM drive -3 computers & $\begin{array}{l}\text { CD-ROM - Majority of computers have a } \\
\text { CD drive, all newer computers do. Some } \\
\text { with DVD-R (Recordable) capabilities }\end{array}$ \\
\hline $\begin{array}{l}\text { Printers }-4 \text { printers, } 3 \text { dot matrix, one } \\
\text { DeskJet. }\end{array}$ & $\begin{array}{l}\underline{\text { Printers }}-30+\text { printers, inkjet, laser, } \\
\text { networked. }\end{array}$ \\
\hline $\begin{array}{l}\text { Software: Word processing, some } \\
\text { programming, problem solving (LOGO), } \\
\text { not much on basic skills. }\end{array}$ & 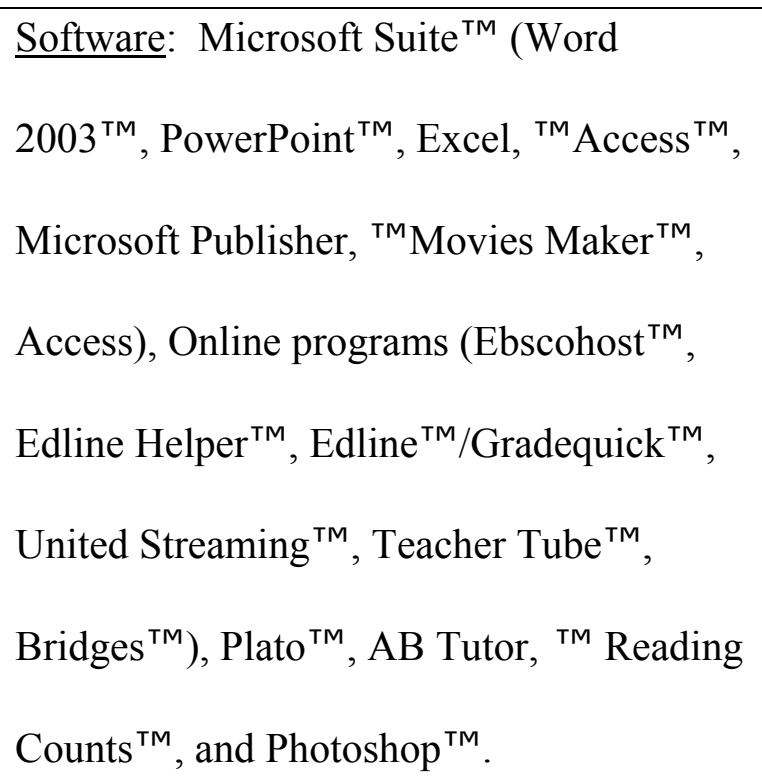 \\
\hline E-mail capabilities: None & $\begin{array}{l}\text { E-mail capabilities: All teachers have e- } \\
\text { mail account and can also send group e- } \\
\text { mails to parents through Edline }{ }^{\mathrm{TM}} \text { account. }\end{array}$ \\
\hline Communication/Messaging: None & $\begin{array}{l}\text { Communication/Messaging: E-mail, } \\
\text { Edline }^{\mathrm{TM}} / \text { Gradequick, websites }\end{array}$ \\
\hline
\end{tabular}


Computers were becoming newly adopted during the 1996-97 study. There were networked computers in the computer lab, but no Internet access or e-mail at the time. The numbers of computers has drastically grown over the past 10 years, which would be expected. The capabilities, speed and software have also been enhanced; just by looking at how the RAM (memory) has increased is phenomenal.

The software has gone away from basic programming and problem solving and is now incorporating productivity tools, research and other online materials. Edline ${ }^{\mathrm{TM}}$ and Gradequick have made a huge impact on how parents and teachers communicate. This technology has helped students stay on track with grades and they can easily monitor their final grades.

Security in the school is also enhanced through the use of technology. The technology has helped make the schools safer by allowing recordings and monitoring of all the happenings throughout the school. Part of the security was put in place because of the Safe Schools act which came about after other school incidences occurring in other parts of the country.

Training in 1997 was just beginning and centralized training courses were not yet available yet. Much of the training was done by the technology teacher or from specialists she recruited to come into the school to train the teachers. Because educational computer technology was so new and resources were limited, the training was pretty basic. One of the early training sessions planned when the Internet connection became operational was on how to use a search engine on the Internet.

Looking at the school ten years later shows increases in technology training for the teachers. Yet, the teachers still feel they could have more training and more time to 
learn the technology. The physical infrastructure has expanded in technology greatly.

Teachers now have access to Internet, e-mail and many other technology resources that were not available in 1997. The next research question looks at how these new technologies have had a impact on the school.

\section{Results for Research Question 3}

Research Question 3: What impact has technology had on administration, coordinators, and teachers who are adopting, adapting and utilizing the new technology?

Technology integration and usage (technology impact on teachers). Looking at technology integration and usage helps assess the impact the technology has had on the teachers. The charts show how often the teachers use the Internet/Computers and other technology. Charts were created from the teacher responses to questions 10 and 11. The data from the interview and survey questions regarding which technology had the most impact were also used to answer the question of technology use and integration. The discussion synthesizing the emerging trends from these three charts can be found at the end of the last chart.

How Internet/computers are used and extent of usage. Survey questions relating to frequency and use of computer applications, but using data from survey question 10.

Survey Question 10: “To what extent do you use the Internet/computers for you job in the following areas? Check the most appropriate response to each item.” 
The responses are coded as follows:

Table 46

$\begin{array}{cc}1 & \text { Extensively } \\ 2 & \text { Often } \\ 3 & \text { Sometimes } \\ 4 & \text { Not Very Often } \\ 5 & \text { Never }\end{array}$

Frequency chart for all responses to Question 10 (Use of the Computer Applications)

\begin{tabular}{|c|c|c|c|c|c|}
\hline $\begin{array}{c}\text { Use of the } \\
\text { Internet/Computer }\end{array}$ & $\begin{array}{c}1 \\
\text { Extensively }\end{array}$ & $\begin{array}{c}2 \\
\text { Often }\end{array}$ & $\begin{array}{c}3 \\
\text { Sometimes }\end{array}$ & $\begin{array}{c}4 \\
\text { Not Very } \\
\text { Often }\end{array}$ & $\begin{array}{c}5 \\
\text { Never }\end{array}$ \\
\hline $\begin{array}{l}\text { Curriculum/lesson } \\
\text { plan development }\end{array}$ & 16 & 7 & 8 & 0 & 3 \\
\hline $\begin{array}{l}\text { In-class } \\
\text { instruction }\end{array}$ & 4 & 8 & 14 & 5 & 3 \\
\hline Student research & 2 & 8 & 12 & 8 & 4 \\
\hline $\begin{array}{l}\text { Instructional } \\
\text { video } \\
\text { conferencing }\end{array}$ & 0 & 4 & 6 & 4 & 24 \\
\hline $\begin{array}{l}\text { Online } \\
\text { collaboration }\end{array}$ & 0 & 2 & 0 & 3 & 30 \\
\hline Virtual field trips & 0 & 2 & 2 & 7 & 23 \\
\hline $\begin{array}{l}\text { Educational } \\
\text { closed circuit TV } \\
\text { programs }\end{array}$ & 0 & 2 & 9 & 6 & 16 \\
\hline E-mail parents & 10 & 13 & 9 & 1 & 2 \\
\hline E-mail students & 1 & 3 & 9 & 12 & 10 \\
\hline $\begin{array}{l}\text { Online grade } \\
\text { databases } \\
\left(\text { Edline }^{\mathrm{TM}}\right)\end{array}$ & 29 & 4 & 0 & 1 & 0 \\
\hline Instant message & 1 & 1 & 1 & 4 & 27 \\
\hline Educational blogs & 0 & 1 & 3 & 6 & 30 \\
\hline Listservs & 1 & 1 & 5 & 6 & 22 \\
\hline
\end{tabular}


Other technology usage and frequency of usage. . Survey questions relating to frequency and use of technology devices, but using data from survey question 11 .

Analysis of Question 11: “ To what extent do you use the following additional types of technology for your job (Check the most appropriate response for each item.)" The responses have the same coding as question 10 . 
Table 47

Frequency chart of all responses for question 11 (Use of Other Technology)

\begin{tabular}{|l|c|c|c|c|c|}
\hline \multicolumn{1}{|c|}{ Use Of: } & 1 Extensively & 2 Often & 3 Sometimes & $\begin{array}{c}4 \text { Not very } \\
\text { often }\end{array}$ & 5 Never \\
\hline $\begin{array}{l}\text { Fax } \\
\text { machine }\end{array}$ & 0 & 4 & 12 & 13 & 7 \\
\hline $\begin{array}{l}\text { Electronic } \\
\text { whiteboards }\end{array}$ & 1 & 2 & 8 & 7 & $\begin{array}{c}19 \\
(2 \text { willing })\end{array}$ \\
\hline $\begin{array}{l}\text { Digital } \\
\text { camera }\end{array}$ & 1 & 4 & 12 & 7 & 10 \\
\hline PDA & 2 & 1 & 2 & 7 & 23 \\
\hline LCD panel & 1 & 6 & 5 & 7 & 17 \\
\hline
\end{tabular}

Interview (Appendix C) and Open-Ended Survey Questions (Questions 12-18)

Impact of technology. These questions looked at which technology device or application had the most impact on the teachers, using data from the following questions.

Survey Question 13 and Interview Question 2: "Which computer technologies do you feel have had the most impact in the school?"

Responses from the answers in the survey question and interview can be found in Table 48. Note that some respondents gave more than one answer to the question and all answers were recorded, so the total equals more than the total participants.

All quotes from the interview or open-ended part of the survey are anonymous, so no individual names are used in the results section. The principal and County Director of Technology were identified by their title, since their administration positions may provide a different view of the technology than the view of a classroom teacher.

Table 48 
Frequency of responses for survey question 13 and interview question 2 (Which

Technology had most impact)

\begin{tabular}{|c|c|}
\hline Technology that Had Most Impact & Number of Teachers Answering \\
\hline Edline $^{\mathrm{TM}} /$ Grades/Gradequick & 12 \\
\hline Insert/Search Engines/Research & 9 \\
\hline Classroom computers/Laptops & 7 \\
\hline $\begin{array}{l}\text { Microsoft Office }{ }^{\mathrm{TM}}: \text { Powerpoint } \\
\text { Processor, Lesson plan template }\end{array}$ & 6 \\
\hline E-mail & 6 \\
\hline United Streamin ${ }^{\mathrm{TM}} \mathrm{g}$ & 5 \\
\hline LCD projectors/Overhead projector & 4 \\
\hline Plato $^{T M}$ & 3 \\
\hline Graphing calculators & 2 \\
\hline Digital Graphics & 1 \\
\hline Reading Counts $^{\mathrm{TM}}$ (Quizzes for books) & 1 \\
\hline Books-on-tape & 1 \\
\hline Blogs & 1 \\
\hline HTML programming & 1 \\
\hline None & 1 \\
\hline
\end{tabular}

Edline $\mathrm{TM}^{\mathrm{M}} /$ Gradequick was shown to have the most impact on the teachers at this school (Table 46). Twenty-nine of the teachers say they "Extensively" use this online grade book. When asked which technology had the most impact (Table 48), 
Edline $^{\mathrm{TM}} /$ Gradequick was the top response. Here is what one of the teachers said about Edline $^{\mathrm{TM}}$ in the interview; "Edline helps keep kids ahead by providing communication with parents and teachers. A lot of time kids get back papers and ditch them. Parents come in and ask 'How come Jimmy got a D in math?' I can't contact every parent every day. It is a handy tool for parents and teachers alike.” (see Tables 46, 47 and 47)

Curriculum and Lesson Plan Development using Internet Research is another way the teachers use the technology. In the survey (Table 46) 16 teachers responded that they use the computer "extensively"; $93.9 \%$ of all the teachers chose "Sometimes" or above as their response, showing that computers are being utilized as a tool for curriculum planning. In the opened-ended survey question (Table 48), nine people said the Internet/Research was the technology that had the most impact,

The Internet has provided new lesson plan ideas for the teachers within minutes. Textbooks offer websites for additional teaching materials. Teachers can collaborate and share ideas with other teachers about their curriculum. The Director of Technology for the county discusses the vast benefits of the Internet for teachers in her interview, "The PC has provided a seamless networking system where the Internet has opened up the world for collaborative, easy access."

E-mail has been adopted by the teachers and society as a communication tool. Teachers regularly receive e-mail messages from the administration to keep everyone informed of upcoming events and other situations. According to the survey question (Table 46), teachers get and receive e-mail from parents, with 23 teachers saying they "extensively" or "often" e-mail parents. The teachers less frequently e-mail students with 22 teachers responding "not very often" or "never", one reason being that the school does 
not provide the students with an e-mail account. In the open-ended survey (Table 48), six teachers said that e-mail had the most impact. One teacher wrote, "E-mail has provided a good communication tool with parents. It is often hard to reach me by phone during the day because I am in class. Through e-mail the parents can send me a message and I can get back to them right away."

Microsoft Office ${ }^{\mathrm{TM}}$ was also mentioned as having an impact. Use of programs like Word $^{\mathrm{TM}}$ for word processing, Power Point ${ }^{\mathrm{TM}}$ for presentations and Excel $^{\mathrm{TM}}$ for spreadsheets are used throughout the school. Six people said that this technology had the most impact (Table 48). Many of the teachers use the lesson plan template, created as a table in Word to create their lesson plans. On the open-ended survey question one teacher wrote, "Doing my lesson plans in the lesson plan template allow me to easily change my plans when situations come up, like snow delays, where otherwise I would have to do a lot of erasing and editing my plan book."

Other teachers use Power Point ${ }^{\mathrm{TM}}$ to create presentations for their class. A science teacher used $\mathrm{Excel}^{\mathrm{TM}}$ to create spreadsheets from an experiment and the math teacher used spreadsheets to record probability findings.

The teachers are not the only ones using these programs either. Using these basic productivity tools is a learning outcome for the students. Students are encouraged to type papers and edit them using Word $^{\mathrm{TM}}$. They also create Power Point ${ }^{\mathrm{TM}}$ presentations for reports. Programs like Microsoft Publisher ${ }^{\mathrm{TM}}$ are also used to create brochures about books they read or other topics.

\section{United Streaming $^{\mathrm{TM}} /$ Plato $^{\mathrm{TM}} /$ and other class instruction uses to enhance} instruction also had an impact. Teachers are using programs such as the Internet based 
United Streaming $^{\mathrm{TM}}$ (http://www.unitedstreaming.com), which is through the Discovery Channel $^{\mathrm{TM}}$ and allows a searchable database of thousands of educational segments to use in the classroom. Plato ${ }^{\mathrm{TM}}$ (http://www.plato.com) is a technology-based teaching tool that provides personalized instruction with standards-driven assessment. For the survey question (Table 46), 14 of the teachers say they "sometimes" use technology for in-class instruction. There were 12 teachers who responded "Often" or "Extensively" and eight who responded "not very often" or "never." For the open-ended survey (Table 48) five people said United Streaming ${ }^{\mathrm{TM}}$ had the most impact and 3 people cited Plato $^{\mathrm{TM}}$.

In the interview one teacher spoke about United Streaming ${ }^{\mathrm{TM}}$, "I use United Streaming for science and health. I can go on the computer and if I am talking about a particular scientist, I can bring up a clip on that scientist."

Classroom Computers/Laptops were chosen as having the most impact by seven teachers (Table 48). In the school there are two computer labs (30 each) and a library computer lab (15 computers) that teachers can reserve for full class. Based on the infrastructure study, each classroom has 1-5 computers for in-class use. There is also a mobile lab of 15 computers for special education teachers to use in their classrooms. A teacher responded in the open-ended survey about what technology had the most impact, "Special Education teachers this year received 15 laptop computers to use in their classrooms and that has helped me teach my students."

The principal of the school said, "I like the computer labs because a mass group of students can utilize the computers at one time. One problem is we only have three computer labs for 600 kids." Another teacher discussed the availability issue when she said "I don't use computers in the classroom due to the limited availability." 
Interactive Whiteboards were recently adopted in the school. Currently five classrooms (one in each grade level and Special Ed.) have the whiteboard. Teachers have had limited training on the whiteboards but more courses are offered in the summer and in after-school seminars as more people get them in the classroom. The survey (Table 47) showed that eight people "Sometimes" use the technology. Also there were several people in the "Never" category that said they would be willing to try. One teacher spoke about the whiteboard in the interview, "The interactive whiteboard has had a huge impact. It is similar to the old fashion chalkboards, but it keeps the students attention better. Students can use the electronic pen and change the color of ink on the displays." The County Director of Technology discussed whiteboards "Lately, whiteboards are the hottest thing. You can implement all resources right there. There are tools for kids to do online collaboration. You have the resources outlined on the website. Everything you need in one area. It is very engaging...There are 700 classrooms in the county and about 100 of them have them (an electronic whiteboard), our goal is for every classroom to have one."

Then there was one teacher who found the technology to be less beneficial. She said that she found the technology that has the most impact in her classroom is the (lowtech) overhead projector.

Other Technology that teachers felt had the most impact (Table 48) included Reading Counts $^{\mathrm{TM}}$ (http://teacher.scholastic.com/products/readingcounts/), which is a Scholastic ${ }^{\mathrm{TM}}$ program where students read books that have certain point values and they take online quizzes on the books they read. The school then can use those points in various ways. One teacher at this school requires that the students have a certain number 
of points per grading period as part of their reading grade. Classes have rewards for students who receive the highest score per grading period.

Another teacher mentioned digital graphics, which would be programs like PhotoShop. Students can use the program to edit and change pictures. Books-on-tape was another technology mentioned by one teacher in the interview, "As a reading teacher, I feel that books-on-tape has been the technology that has had the most impact. It provides a different type of delivery with DVD/CD/visually online and reading. It provides another way to look back at a book. It helps all levels of learners."

What impact has technology had over the past 10 years? These questions looked at the teachers/administrators opinion to reflect on which technology has had the most impact over the time frame of the study. The following questions were used to answer this question.

Interview Question 1: “In your opinion, what impact has technology integration had on the school over the past 10 years?"

Survey open-ended question 12: "Briefly describe the impact that computers have had on your work as a teacher?"

After analyzing the interviews and the written open-ended question responses, the following responses emerged from the data. 
Table 49

Frequency of responses for survey question 12 and interview question 1 (How has

Technology had an Impact)

\begin{tabular}{|c|c|}
\hline What Impact Technology Has Had & Number of Responses \\
\hline $\begin{array}{l}\text { Advantage of online grade book with } \\
\text { Edline }^{\mathrm{TM}} / \text { Gradequick }\end{array}$ & 7 \\
\hline Useful in writing lesson plans & 6 \\
\hline E-mail and communication with parents & 6 \\
\hline Gain content of subject area & 5 \\
\hline Research/Internet & 5 \\
\hline $\begin{array}{l}\text { Multiple activities/broad use of the } \\
\text { technology }\end{array}$ & 3 \\
\hline Use of whiteboard enhances lessons & 2 \\
\hline Benefit in writing IEP's & 1 \\
\hline Web design and problem solving & 1 \\
\hline Useful to order supplies & 1 \\
\hline Helpful in creating classroom materials & 1 \\
\hline No Impact & 2 \\
\hline Causes more work and stress & 2 \\
\hline Positive impact & 2 \\
\hline Necessary part of my job & 1 \\
\hline
\end{tabular}


The above chart was developed by synthesizing the written responses from question 12. The teachers' responses here were similar to the technology frequency use chart above, with Edline ${ }^{\mathrm{TM}} /$ Gradequick, lesson planning, and e-mail/communicating with parents coming up as the top areas of impact. One of the interviewed teachers said, "I think it (technology) has had a big impact. Students access websites and get a lot of information. I have used a lot of math websites and it was a big help." Another teacher felt differently about technology in her interview. She said, "(Technology) is trouble. There is limited availability of labs. The classroom computers are outdated. There is not a lot of training on new software. We have a lot of impressive technology but without training you can't use it. I have a problem with having four grade levels and one lab (the other lab has computer classes all day). You can't use the computer lab the way you would like to and it is not available every class period." The views vary so widely about the technology; here is a sampling of the responses from different teachers; "I use them every day, I luv them.”; “Computers cause more work and stress.”; “ They have made my life easier" , "Some help but mostly work"; "It makes grades and lesson plans quicker. Also, it is easier to communicate with parents."

A teacher identifying herself as the library/media specialist commented, "I have seen more teachers using each technology yearly - from a library/media specialist viewpoint - more are using laptops, LCD projectors, more using United Streaming and Internet site." This teacher gets a good view of the use of technology, since many of the teacher reserve the equipment through the library.

The principal's response regarding the impact, "Technology is huge across the country. We have technology enhanced curriculum with kids researching on the Internet. 
There are many research tools available for the students to use. Plus the new whiteboards, portable computer labs and other technology we have just introduced to our school just enhance the educational process. On a scale of 1-10 for technology, we are a 20! There is a good bit of technology here at ABC Middle School and the teachers are using the technology constantly!" She went on to say, "We are working as hard as we can on initiatives to use the technology as a tool to enhance curriculum... we need to embrace the technology and be able to enhance our curriculum."

The County Director of Technology's response regarding the impact of technology: "Technology has taken students to a higher level of thinking when used as a tool. Probably ten years ago, teaching technology was just teaching the mechanics, like in a business class, with some drill and practice type activities. Today teaching technology is teaching everything. Now we focus on problem-solving, collaboration, more efficiency. It takes the students to a higher level of thinking"

Additional measures to enhance technology. This question provides a guideline to what the teachers say the need to be able to more effectively integrate the technology. The following questions were used to answer this question.

Survey open-ended question 17: "What additional measures could be taken to enable you to make more effective use of computer technology? (This might include additional training, computer hardware or software enhancements, etc.)" "Data from the interview question and survey question were analyzed and organized into the chart below."

Relevant quotes are included in the description. Table 50 
Frequency of responses for survey question 17: (How to Make More Effective Use of Technology)

\begin{tabular}{|l|c|}
\hline \multicolumn{1}{|c|}{$\begin{array}{l}\text { Measure to Make More Effective Use of } \\
\text { Technology }\end{array}$} & Number of Responses \\
\hline $\begin{array}{l}\text { More training: Hands-on, small group, } \\
\text { weekly, in my classroom }\end{array}$ & 13 \\
\hline Time for training/implementation/learning \\
about computers
\end{tabular}

Training- Training continues to be an issue when asked how to make technology use more effective. One teacher said "I need more training, during school hours on Instructional Support (ISE) days, not staying after school"; "Training on a regular basis."

Time - Teachers are pressed for time to learn about the computers. Many teachers responded, "I need time to explore"; "Time away from students to train, plan and implement the computers."

Equipment- There is a need for more computers and updates on the computers they already have. "I need more computers in my classroom." "We need bigger computer 
labs and scheduled time to use them so we can get all our classes in on the same days." "Update the computers in my classroom, they are slow and don't run half the time." (See Table 50).

Drawback to technology in the classroom. One drawback to the technology is the change in ways kids interact with each other. "I have been teaching 28 years and the more technological advanced society has become the more social problems in society. You don't have person-to-person interaction. Kids are able to get along with less and less personal interaction."

Another drawback is the limited technicians to repair and update the computers. The County Technology Director says that there are over 4,000 computers in the county and only three technicians to repair the computers and install new computers. The Technology Contact in the schools helps facilitate the repairs and assists the teachers, but this is only for two class periods of the day.

Another teacher felt that computers are doing a lot of the work for the students. "The computers do spell check, not requiring the students to learn how to spell correctly. The students use search engines to find research information instead of using the library to find books. They are not doing as much problem solving; it is just giving them the answers without having to think."

Then there are the teachers who just are not embracing the technology, no matter how much training or support they get. One teacher wrote, "I hate computers!" With teachers like this, it is going to require significant changes in attitude before they are going to accept the technology. They like the way they teach and are against changes in their methods, even if a better way is available. The County Technology Director 
addressed this in her interview, "We as teachers are digital immigrants, while the students are digital natives. If a teacher shows they don't like the technology, it turns the students off...Teachers need to stay in tune to new technology and never say, 'I will never do that."

Finally, the financial consideration also plays an important factor in the future of technology at schools. The County Technology Director says, "I look at the infrastructure and not the technology and tools. I am frustrated that everybody can not have everything when they need it, but due to financial constraints that is not possible."

The Future of technology in the schools. How will technology be used in the schools in the future? The interviewees were asked the following question to help answer this question.

Interview Question 5: 'What do you see in the future for technology in the school? What measures could be taken to make computer technology more effective in the future?"

What are the schools going to look like in the future in regards to technology?

One teacher said, "I think at some point there won't be a teacher in a classroom. Teachers will be at a hub and students will plug in. There will not be a classroom with students at a desk getting lessons."

Another teacher predicts, "The technology will constantly need improving. What first graders know now will be changing with what the first graders will know in the future. Will the school system be capable of keeping up with it? The computers will keep expanding into our teaching and learning." 
The principal predicts, “There will be one-on-one computing through devices like the cellular telephone and the I Pod. Everybody will have the capabilities to connect too, especially with the drop in prices of the equipment."

One teacher sums up by saying, "The world is moving to a technological transmission of data. Students must know how to move in this world with a computer of some sort."

The County Technology Director predicts, "I would like to see each student having their own laptop computer on their desk in the future. They can get online and use the resources as part of the classroom instruction. This could be a good or bad thing depending upon how we engage the students in the learning with the technology."

Technology has definitely had an impact in this school over the past ten years. There are some applications (Edline ${ }^{\mathrm{TM}}$, Internet for lesson planning, and E-mail) that the teachers have whole heartedly adopted and integrated into their teaching. Teachers still need more training and support in other areas.

The administration has encouraged the use of technology by requiring teachers to use some of the technology. The principal was supportive of the teachers and has high expectations to use the technology in the curriculum.

The County administration also has promoted technology use by providing training, a Technology Contact person in the school, and financial resources to purchase new equipment. It is also important to note that technology was included in the curriculum goals and objectives, further showing the importance of the technology.

The school will continue to grow and with the proper support, training, motivation and resources, this school will continue to technologically thrive. This school is on the 
road to providing a technology-rich educational environment that will help lead the students into the $21^{\text {st }}$ century. 


\section{Chapter V}

\section{Conclusions, Limitations, and Implications}

Review of Chapters 1-4

The purpose of this study was to determine if any changes in technology integration and adoption of computer technology had taken place at ABC Middle School from the initial pilot study in 1997 and the follow-up study in 2007. This research looked for changes in the teachers' computer anxieties, attitudes and computer use from the previous study. Research showed that teacher anxiety had an impact on the teachers' willingness to integrate the technology into their curriculum. So it is important to understand the anxiety level in order to assess the willingness-to-integrate level.

This study also looked at the computer technology infrastructure; including the physical components, connectivity, and training in 2007. A comparison was also made to see how the infrastructure had changed over the past 10 years. Research showed that in order to have strong technology integration, the infrastructure must be kept up-to-date and accessible. Finally the study looked at the impact these changes had on the school. The technology impact question looked the level (frequency of) integration, attitudes, and training in the school. Research showed that by having a strong technology strategy, the impact of the technology in the school increases.

The study provided a guideline for where the school was in regards to technology anxiety, technology integration, training and infrastructure in 2007. This helped to provide a guide as to what areas of training, infrastructure or support are still needed in the school system. Research questions for this study are as follows: 
o What are the differences in readiness of the classroom teacher from 1997 and 2007 in their ability to integrate instructional technology within their teaching activities?

- What are the differences in the technology infrastructure at this school from 1996 and 2007 including the changes in support, physical changes and training over the past 10 years?

- What impact has technology integration had on administrators, coordinators, and teachers who are adopting, adapting, and utilizing the new technology?

Results from the study found that teachers have less anxiety towards using computers in 2007 than they did in 1997. There is an even more negative correlation between the level of anxiety and level of training. Teachers still had an overall positive attitude about the use of computers, but still have some frustrations. Lack of time, not enough of the right kind of training, and frustration over the outdated computers were major areas of concern that were found in the study.

The infrastructure of the school had definitely increased, with more computers and faster computers. Internet connection, e-mail and a Local Area Network also enhanced the technology in 2007. Other devices, such as the interactive whiteboard and increased security features have also been incorporated into the school. Teacher training had also become more specific. The level of training had increased from 1997 to 2007 , yet many teachers still feel they could benefit from more training when it comes to using the new technology. Developing different training strategies and providing time and support for the teachers would enhance their technology integration. 
Technology has had an impact on the teachers. Findings from this study showed that all of the teachers in 2007 were using the technology to some degree. Major uses include Edline ${ }^{\mathrm{TM}} /$ Gradequick, use of the Internet for lesson development, curriculum planning, and communicating with parents via e-mail. All of these are examples showing the teachers readiness in adopting the technology, and these applications were not even possible in 1997. Technology will be part of the future and it is important that the school continues to increase its infrastructure, provide support and training, and encourage technology to further enhance the education of the students.

Conclusions related to research questions

\section{Results from Research Question 1}

Research Question 1: Compare the differences in readiness of the classroom teachers from 1997 and 2007 in their ability to integrate telecommunications within their teaching activities.

Results from 2007

Anxiety. A negative correlation was found between computer knowledge and computer anxiety. A teacher who had more anxiety toward the technology was not as likely to embrace the new technology. It is important that the teachers receive the technology knowledge they need (through training and support), thus reducing their anxiety level. Looking at the 2007 study, many variables were used to test anxiety levels. Throughout the survey questions, results showed the teachers had a relatively positive attitude towards computers (with a mean of 2.94 in one set of analysis and 3.10 in another - with 1 being a negative attitude/high anxiety and 4 being total comfort/low anxiety). 
Teachers in this school have an overall good level of self-confidence in using the technology; they feel the right amount of emphasis is being placed on using computers for teaching and learning. The teachers also showed that they are interested in learning about computers to be an effective teacher, and they also did not feel overwhelmed about using the technology. A majority of the teachers agreed that they don't feel they have enough time to adequately use the technology.

Additionally, the majority of the teachers agreed that computer literacy should be a learning outcome for the school system (technology goals are included in the curriculum objectives already). According to the study, teachers did not like the idea of having computer use limited to the computer lab only, but instead agreed that all classrooms should be equipped with (up-to-date) computers. Teachers and students should both learn to use the Internet, according the majority of the participants. Finally the teachers did not agree that computers and Internet have limited applications in the subject area they teach.

From the open-ended questions and interviews, the results on anxiety were similar to the findings for the survey questions on anxiety. There is a majority of teachers who have a moderate or low level of anxiety and only a small percentage who have a high level of anxiety. Looking at the graphs helped to show the breakdown in high and low anxiety participants. The levels of anxiety could be classified as high, moderate and low at the school. A fourth category also emerged and that was the "no desire" category. They just don't like the computers even though they don't have a lot of anxiety about using them. 
Age range and computer use. The analysis showed no significance in means of the groups, meaning that the age of the participant did not matter in regards to their level of use. This means that teachers, regardless of their age, will be equally willing to use the computers in the school. This may go against a common misconception that "older" teachers are not as willing to use the technology as the "younger" teachers. The findings in this school did not hold true to that conception.

Knowledge of computer technologies and amount of computer training. The analysis of these categories found a significance. The means of the different categories should not be considered equal. It appears that the more training the teacher had, the more knowledge they had, which would make sense. This continues to show the importance of training the teachers so they can gain more knowledge of the computers. In turn, they have less anxiety and are more willing to integrate and use the technology.

Knowledge of Internet technologies and amount of Internet training. The analysis of these categories did not show significance. Conclusions from this analysis showed that there had not been as much formal training provided, yet the knowledge level was higher, indicating the teachers may have self-taught in using the Internet.

Area of specialization and computer use at school. There were no significant differences in means in these categories. Looking at the chart showed that the English teachers and related arts teachers had a higher mean of using the computers, while the social studies and science teachers had the lowest use. The related arts category also had the largest number of participants, and some of those teachers use the technology extensively (such as the computer teacher and the technology education teacher). 


\section{Years of teaching experience and amount of instructional technology training}

received. There were no mean significances among these categories, but it should be noted that the teachers with more years of teaching had a higher group mean. One point that was brought up by one of the teachers with less years of experience, is that the staff as a whole had training, but they don't offer it again for the new teachers. She suggested that the county offer a "mini-technology" course for all new employees to help get them up to speed on the technology for which some of the more experienced teachers have already been trained.

\section{Conclusions for Research Question 1 (2007 Study)}

Teachers at ABC Middle School are showing readiness and willingness to adopt technology into the curriculum. Their level of anxiety towards the technology is overall positive. There was also no significant differences in the teachers use in regards to their

age range, number of years teaching, or knowledge of computers. A negative correlation in computer knowledge and reduced computer anxiety was found, as well as a significant difference in level of computer training and level of computer knowledge. These three areas are all related because having more training increases the level of knowledge, which decreases the level of anxiety. Teachers with a lower level of anxiety are more ready and willing to use the technology in their classroom.

\section{Compare 1997 and 2007 Results}

Anxiety comparison. The teachers in 2007 reported less anxiety towards computers than they did in 1997 . The correlation between low anxiety and willingness to 
adopt the technology showed a negative correlation in both studies, but the relationship was even stronger in the 2007 study.

A Comparison of the three questions used to assess anxiety from 1997 and again in 2007, showed an interesting finding. When asked if all classrooms should be equipped with computers, the mean was higher in 1997 than in 2007. While teachers in 2007 still mostly agreed that there should be computers in the classroom, they did not agree as strongly as they did in 1997. There could be several reasons for this, including outdated computers that do not function appropriately, not enough computers in the classroom to really be useful, and the type of software being used. Now there's less drill and practice software, which can be used on a more independent basis. Also, now there's a need to supervise the students while on the Internet, which is harder to do while teaching other students.

Similar results were also found in comparing the results on students and teachers using the Internet. The teachers in 1997 had a higher mean of agreement than in 2007 for both categories. While both groups showed agreement to using the Internet, the level of agreement was weaker in 2007. This could be because of the "dangers" of the Internet that are more prevalent and more widely understood in 2007 then they were in 1997.

While looking at specific comparisons of these questions, it showed the level of agreement was lower in 2007, possibly because of the mandatory requirements of the technology in 2007 that was not mandated in 1997. In the 2007 study, teachers are feeling more pressure to use the technology, thus possibly making them less enthusiastic. Teachers may also feel more pressure to use the technology and feel more pressed for time as the technology is taking up more of their time as they are required to do more 
with the technology. The overall thought in 1997 was that the technology would be more of a "time-saver" and the teachers understood the time commitment more clearly in 2007.

Computer use outside of school comparison. Teachers used the computers outside of school at a higher rate in 2007 than they did in 1997. This showed that if teachers are using the technology outside of school, they are showing integration of the technology in their lives.

Computer training comparison. Teachers had a substantially lower level of computer training in 1997 than they did in 2007. One of the recommendations from the 1997 study was the need for more training to help reduce the anxiety level, which in turn promote more technology integration. While training has increased, there still is a need to continue to train and support these teachers in 2007 and beyond.

\section{Conclusions about Comparisons of 1997 and 2007.}

In both studies, the teachers were showing positive readiness in adopting the technology. By 2007, there was evidence that the technology is being adopted into the classroom. Teachers' anxiety levels are less in 2007 than they were in 1997. The reasons for anxiety have shifted though. Earlier, just the idea of using the technology was causing anxiety. Now some technology applications have been incorporated into the school with little or no anxiety in their use. But, the newer technologies are what is causing some stress. This shows the need for continued technology training to keep the teachers up-todate and comfortable with the new technology as it becomes available. 


\section{Results for Research Question 2}

Research Question 2: Compare the differences in the technology infrastructure at this school, including the changes in support, physical changes and training in 1997 and 2007.

Results from 2007

Training. Teachers in the school have had different levels of training. A large group of teachers felt they had not been adequately trained, while another group stated they had been well-trained. Some of the discrepancy could be that the teachers who were well trained sought out voluntary training through the county, through the Technology Contact teacher, through other classes, or through previous training (like in college). The school as a whole has not received enough training, or the right type of training to make the group as a whole feel well-trained. Several teachers say that the type of training also factors into their retaining of the material. By having one long training session, the teachers felt overwhelmed with material and don't have the time to practice the material and get the further instruction as they need to use the training in practice.

Time was cited as a big factor for not having enough training. Many teachers responded that they don't have time to get training or time to use the technology. Teachers expressed a need for more scheduled time to learn and use the technology.

Support for using the technology was also cited as a need. Teachers wanted help with the technology during and after the training. Having someone to turn to for help also would reduce their anxiety.

In what areas do the teachers need training? Results from this question were interesting. Even though a significant number of teachers responded that they did not feel 
adequately trained, a significant number of teachers said that they did not need any training (or did not respond) to this question. There could be several explanations for this. Possibly time played a factor, because the teachers felt that they don't have time to be trained. The teachers may also have felt the long training session they usually received did not suit their learning style. This would be an area to further explore.

The areas where there were a lot of requests for training were the interactive whiteboard, which the school just adopted. Another group just wanted training on any new technology and could use refresher training on technology already in use. Teachers also showed an interest in having content-specific training so that they can gain useful learning strategies and content material for their subject areas.

\section{Comparing Training in 1997 and 2007}

Teachers report that they had received more computer/technology training in 2007 than they did in 1997. In 1997 teachers were just learning the very basics on how to use the computers and were not doing a lot of integrating the technology into their classes. In 2007 the training was more specific to applications and new devices and less on basic operations of the computer.

\section{Physical Changes in Infrastructure from 1997 and 2007}

The technology infrastructure has dramatically changed from 1997 to 2007 . The school now has more computers, faster computers and Internet capabilities. The types of programs and applications have also changed over the ten years. The Internet has become a widely used research tool. There are many Internet-based programs that are 
widely used in the school. Security also showed a big boost because of the technology that was put into place.

The teachers in 2007 are using the computers to do activities that were not even possible with the technology of 1997. It would be interesting to think ahead at how much the technology will change in the next 10 years.

\section{Results for Research Question 3}

Research Question 3: What impact has technology had on administration, coordinators, and teachers who are adopting, adapting and utilizing the new technology?

Impact Teacher: Technology Usage and Frequency. All teachers at the school are using the technology in some capacity in 2007. The top usage application is Edline ${ }^{\mathrm{TM}} /$ Gradequick, which was cited as "Extensively" being used by most of the teachers. Also many teachers cited this as the one area of technology that had the most impact on them. Edline ${ }^{\mathrm{TM}} /$ Gradequick provided an online grade book that parents and student can access. It also provides a place for teachers to post assignments or other announcements. Edline $\mathrm{T}^{\mathrm{TM}} /$ Gradequick has definitely been adopted and embraced by the parents and teachers as a wonderful way to provide continuous updates and communication.

Another prominently used technology is the Internet for curriculum planning and lesson plan development. Teachers showed a high level of frequency in using the technology for this purposes and many also stated it was the technology application that had the most impact. Teachers felt comfortable with searching on the Internet and using the technology to find resources for their classroom. 
E-mail was cited as another way that technology has impacted the teachers. Many teachers say they regularly e-mail parents and find this form of communication to be valuable. The e-mail capabilities combined with the Edline ${ }^{\mathrm{TM}}$ has greatly impacted the communication between teacher and parent. Other applications and devices such as United Streaming ${ }^{\mathrm{TM}}$, Plato ${ }^{\mathrm{TM}}$, and interactive whiteboards were also mentioned as important areas of technology for the teachers.

How does this compare to 1997? Many of these technologies did not even exist during the first study and even if they did, the school did not have the capabilities to use them. There were no online grades, no Internet, and no school e-mail. The only technology for which teachers mentioned in the 2007 study that was also available in 1997 was the word processing program. To think that in this 10-year span teachers have adopted and embraced a technology that they did not even have the capabilities before, shows the impact that technology has had on the teachers. Teachers are now adopting at least part of the new technology, adapting to using the technology and finding ways to integrate it into their lesson planning and curriculum.

Impact: administration. The administration at the school has encouraged the staff to embrace the technology. She said that the technology has enhanced the curriculum; students are all using the technology and she rates the school rates very highly in regards to technology implementation.

Impact: coordinator. The County Technology Director for the county shares her enthusiasm for technology. She felt that the computer and Internet have opened up a whole new world of education for the students. The County Technology Director 
continues to support technology by getting finances to put more computers in the schools, providing training for the teachers, and encouraging technology advancement (such as having technology goals included in the curriculum objectives).

How to make more effective use of technology? Teachers would like to see more training that is hands-on, in classroom, weekly training. They also need more time to effectively practice and implement the training. Hardware and software also needs to be upgraded and updated to provide the latest technology to the schools.

Drawbacks of the technology. There were several areas that were considered drawbacks to the technology. Students are have less interpersonal interactions since they are using the technology more and more. This causes more disturbances in the classroom. There is also the factor of up-keep for the computers and having limited people able to keep all of the schools technology up and running is a large job. Financial restraints are also a factor in being able to purchase new technology and to keep the technology in place operational.

Future of technology in the school. Students going to having an independent computing device, was mentioned several times as the way of the future. Each student would have a device (be it a cell phone, I Pod, laptop computer) to use much as paper and pencil is used today. Some foresee a point when students don't even sit at desks, but work from their computers at home and connect electronically to a teacher. Whatever the future classroom looks like, one thing is for certain, technology will continue to change, and students will continue to know more about technology from early in life. Teachers and schools must meet the challenges of the future and be willing to adapt to the new 
technology and change the way they do things to embrace the learning needs for the society of the future.

\section{Other Findings}

There was one interesting finding when looking at what technology the teachers say has had the most impact and the technology that they frequently use. The types of programs (applications) and uses that the teachers are embracing are ones that facilitate more of the teacher-side of the technology. Entering grades and messages in Edline $^{\mathrm{TM}} /$ Gradequick do not directly impact the daily instruction. The same is true for using the Internet for lesson planning, which does help the students by receiving better lessons, but does not directly involve them in the computer. The e-mail is also widely used but is more often used with parents and other teachers, not the students. While having parents and teachers have better communication is beneficial to the student, it is not directly involving them in the technology.

While the teachers are using the technology with the students, they don't find those uses to be the highest impact of the technology. One of the goals of the school is to enhance the curriculum with technology, and most of the widely used technology applications that the teachers are using don't directly impact the students. Of course, using United Streaming ${ }^{\mathrm{TM}}$, Plato ${ }^{\mathrm{TM}}$ and Reading Counts ${ }^{\mathrm{TM}}$ are definite ways that the students are directly benefiting from the use of the technology. The school needs to work to find more ways to encourage the teachers to find ways of integrating the technology into their lessons. 


\section{Limitations}

This study looks at a case study to assess how participants' attitudes towards computers, computer implementation, and infrastructure differs from 1997 and 2007. The study looks at just one school, so it may not be generalizable to other school settings that may have had different situations. But, for this population the information can be meaningful for their evaluations and future implementations and may be informative regarding technology integration efforts in other middle schools.

This research also relies on teachers' own perspectives towards using computers and their training and attitudes. The researcher had to trust their self reports. The scope of this research does not include observations of the teachers in the classroom using the technology, or following the teachers through the process of technology implementation over the past 10 years. So, this could not be considered an all- encompassing look at the path that the school has taken over the past 10 years in terms of instructional technology use.

The analysis comparing the first study and second study was somewhat limited because the scope of the first study was much smaller than the scope of the second study. Comparisons could only be made when there were results from both studies available. Nevertheless, the data that was compared helped to give an understanding of the changes that occurred. The more detailed 2007 data will further help the school understand where the teachers currently are in regards to anxiety, attitude, and training and what issues they feel need to be addressed in the future. 


\section{Implications}

Impact of the study in the school and in the county. Technology has been increasingly important in our society. Within a period of ten years, the way that technology has changed has had a huge impact in society. At the beginning of the study (1997), cell phones were available on a limited basis, while by 2007 , a majority of the population has cell phones, even elementary children can be seen sending text messages. Even things like the grocery store became automated with computer sensors. Use of the Internet to communicate, shop, and pay bills has dramatically increased. Students in 2007 are very proficient and emerged in the technology. They are often using the computers to help with their homework, but they are also using it for a social outlet. The students use computers to play games, download music to their I Pods, talk to friends, read blogs and create My Space pages to name a few of the many applications they use on a regular basis. The students are much more computer savvy in 2007 than they were in 1997, since they have grown up with the technology.

The school has also followed the lead of increasing technology integration. In 1997, a majority of the teachers were using chalkboards, overheads and books to teach lessons. Students now have more options available and can gain knowledge at a click of a mouse. It has changed the way the students learn. Students now expect to know their grades immediately on Edline and take an active role in checking their grades. This study showed how Edline did have an impact on the students, by keeping communication lines open with the parents and getting the parents to play a more active role in the day-to-day happenings of the school. 
One example helped to show the dependence on the technology. One teacher spoke about a day when the server and Internet were down in the school. A mild panic broke out among the teachers because they could not access their grades, they could not print out lesson plans, get IEPS, show video clips to students, and even the library could not check out any books because of the automated system. It would be predicted that in 1997, if the server was down there would be little impact on the daily activities of the school. Having the seamless integration of technology helps show the value that technology has and often it may be one of those things that are currently taken for granted.

The school needs to continue to provide a supportive environment for technology integration. The study showed that faculty need more training, support, and time to fully embrace the technology. The school administration should continue to support the school and help address these issues to make technology integration even more successful.

The county has done a good job in making technology a forefront issue in the schools. The County Technology Director constantly applies for grants and works to bring money to the school system. The county has piloted many technology projects and continues to strive for the overall good of the county. The Director also should be commended for providing an equal level of technology for all schools in the county, based on their population. When one middle school gets a Virtual Lab, she ensures that all middle schools will get one in the near future. This provides equal opportunities for all students in the county no matter which school they attend.

The study addressed the issue of increased training and more updated computers. The county can continue to provide the training and support, through the Technology 
Integration Specialists (TIS) or through other options. The county must also continue to upgrade the computers and provide technical support to repair the computers.

What is the impact of this study on better understanding the increasingly complex scope of teachers in schools?

Time. The issue of having enough time to learn about, prepare and integrate the technology was apparent in the findings of this study. What are the schools going to do to help address this issue?

In 2005, the West Virginia Governor's Advisory Council for Technology in Education began to look at the issue of time for technology, among other topics. The committee recommended, "allocation of time - provide incentives and compensation for after school, week-end PD (Professional Development) sessions, provide substitutes (Burrall, Dillard, Robertson \& Taylor, 2005, p.3). Although these initiatives seem like a good starting point in addressing time, it was not apparent that they were being fully implemented (or funded) at the ABC Middle School. There were several training workshops offered in the summer for a stipend or in-lieu of time, but there were limited offerings and limited space available for the classes.

Several other schools use the faculty development time differently and provide some funding for substitutes to allow the teachers to have "technology days" where they can immerse in the technology. There was no funding for substitute teachers provided to ABC Middle during the study.

Training. The teachers said their level of training was increased in 2007 compared to 1997 , but the study showed the need for continued training. The county and school are limited in the training time available during the work day. Many times 
teachers have to choose to do training during the summer or after school, which is not going to work with all teachers.

The WV Governor's Advisory Council for Technology in Education addressed this in their 2005 report, which suggests, "Change the renewal system for teachers that require that graduate hours are based on technology based (courses)....change recertification requirements for administrators and teachers that include technology integration content (Burrall, Dillard, Robertson \& Taylor, 2005, p. 2).Taking this approach would help to encourage the new teachers to gain this knowledge, but it does little for the teachers who do not require recertification based on their permanent certification status. Additionally, the required technology courses for graduate credit renewal would also require the local University to provide such classes. At this time not many technology integration courses are offered, but that could also change if the demand for such courses became more prevalent.

More Student-Centered Technology. Teachers are beginning to adopt the technology, but the results of the study showed that the main uses of the technology were still teacher-oriented. The pedagogy of the schools is moving away from the teacher centered - lecture type lessons to more hands-on student centered lessons. The technology in the schools can be used to create this student-centered approach.

The administration and county must take charge in encouraging the teachers to develop the skills to be able to use the technology in a way to promote student achievement. The NCLB provides federal compliances where the county must show how they are using the technology equipment for student achievement, how they are providing technology integration for student achievement, how they are providing distance learning 
opportunities, and how they are providing increased access for the students to help them achieve. It is the counties responsibility to address these issues in their Digital Divide reports yearly (West Virginia Department of Education, 2008, p. 23). The school and county followed through on this area. While obviously the technology is being used for student use in the school, this study shows that the student achievement is not the main use of the technology at this time.

When speaking with the technology contact teacher, it was clear that a majority of the time in training had to be spent teaching the more basic applications like Edline and Email, because the schools were mandating their use. The school and county would benefit by providing more content-specific hands-on training that the teachers could take back to their classrooms and use.

Technology Standards and Goals for Students: Who is Responsible? The content objectives for the county include Technology Goals and Objectives that the schools are required to include in their curriculum. (West Virginia Department of Education, 2007, Standards and Objectives) The County Technology Director discussed this, "The West Virginia CSO's [curriculum standards and objectives] drive our curricula and instruction and so we choose technology tools that can be seamlessly integrated to help students achieve the learning objectives in our standards." At this point there are no strict accountabilities for who is teaching which objective. From the findings of this study, there are some teachers who are comfortable with and using the technology regularly, but what about the teachers who are not doing so? Are all the students receiving the technology goals they need to succeed? Looking at the data, it would be questionable that every child is getting all the mandated technology skills. 
The county was in the process of helping to correct the accountability issue by adopting a program called Tech Steps. The county was to begin implementing it in the 2008 school year. Tech Steps (www.techsteps.com) is a comprehensive program where the modules covering all of the technology standards from $\mathrm{K}-8$ were intertwined with the subject area core curriculum objectives. Each module was assigned to a specific teacher for each grade level, to ensure that all students will receive all modules. When the students complete the entire series of modules, they will have mastered the computer proficiency level that is mandated through the No Child Left Behind act. 


\section{Chapter VI}

\section{Recommendations}

\section{Recommendations}

Technology will continue to grow in society and the schools need to keep up with the technology to prepare the students for the future in which they will live. The teachers at $\mathrm{ABC}$ Middle School are mostly willing to adopt and integrate the technology; many have already done so and others are moving in that direction. This research study clearly shows that the teachers need time, training, and upgraded computers to feel fully comfortable and have a lower anxiety level in using the technology.

The first section of the paper looks at recommendations for ABC Middle School and how they can use the results from the study to better help the schools' technology integration. The second section of this chapter offers recommendations for a future study based on findings from this study. This section looks at which questions would be asked in a future survey, how that survey would be analyzed, and how technology development can be geared from results of that survey. This provides guidelines for a future study.

Recommendations for ABC Middle School based on this study's results.

Anxiety. Teachers at the school have a relatively positive attitude towards integrating technology. The anxiety is less in areas where the teachers feel well-trained, and anxiety is higher for the areas in which they had less training. For the teachers' anxiety level to decrease even further, it is important that the school continues to provide the training, support, and time for the teachers to feel increasingly more comfortable with the technology. 
Time. The school needs to create time for learning, preparing and implementing the technology. This could be done during staff development instruction days, offering substitute teacher release time to work on the technology, or find other creative ways to integrate. One team at the school had created a "Technology Tuesday" during their team planning. Each Tuesday the team meeting is devoted to learning about the technology and taking time to try the new ideas and share with each other. Other teachers could follow this idea and create a plan that would work with their team.

Training (support). Correlations between training (knowledge) and anxiety were proven in this study. Teachers continued to discuss the need for more training, continued training, and support after the training. As more and more technology is introduced into the classroom, the school needs to continue to encourage and train the teachers. There are many ways to offer training courses: summer workshops, after-school workshops, staff-development day workshops, individualized training with the teacher in the classroom, having a technology support person in the school to provide training, miniweekly training workshops or online training.

Another suggestion that could really benefit is peer observations with other teachers using the technology. If teachers could be given release time to watch another person use the technology, it would really spark interest in how that teacher can use it in his/her classroom. The mentor could be a fellow teacher, a teacher at another school, or the technology teacher showing the use of the technology in a real classroom setting. Training like this would also promote the technology integration used to enhance the lessons, which is not as widely done at this time at the school. It also would help address 
the need for more content-specific applications, by pairing teachers with other teachers in their subject area.

Upgraded computers. Teachers had a lot of frustration in having to use old computers that run very slowly or do not do work as they should. The school system is under financial constraints in purchasing computers, but is trying to update when possible. Schools could also look at other ways to update. Some businesses replace computers on a regular basis, and the "replaced" computers are still often newer than the school's computers. Schools could work with parents and local businesses for fundraising efforts for new technology as well. There are also mini-grants and other funding available that schools can use to help get additional resources in their school.

ABC Middle school is doing a good job incorporating the technology and by providing more time, training, support and upgraded computers they will be able to help the students move forward in the 21 st century with skills needed to succeed in the future.

\section{Recommendations for Guidelines of a Future Study.}

School Technology Use Survey. The scope of the survey used for this study was somewhat limited by the initial study from 1997. Using the findings for the 2007 study, the following recommendations are made on what to include in a future study.

The mixed method design should continue to be used. The findings were better explained because of the mixture of quantitative and qualitative data collected. One suggestion that could be made is to mix the open-ended questions in with the statistical questions. For example, when the teachers completed a section on technology usage 
(such as question 10 and 11 in the survey), under that question would be a question that says "Which technology has had the most impact and why?" This would allow the teachers to respond as they are still thinking about the technology usage.

The questions should focus more on how to improve the technology integration and uses, based on the findings from the study. The questions should move away from the "technology readiness" that was addressed during the first study, because the school has demonstrated their readiness through the utilization and integration that has taken place. The focus of any further studies should be to provide the elements the teachers need to further expand the technology use.

The future study should move away from assessing anxiety and comfort levels, because the 2007 study has shown that training (knowledge) has a negative correlation on anxiety. It is not as important to look at teachers' anxiety level, but instead to look at how the schools can better train the teachers.

Some of the statistical questions should be more of a frequency-chart style instead of a straight Likert-scale to allow more data beyond just the degree, but also to include the frequency.

Categories of questions are listed below, with examples of how the questions should be written. Below each bulleted question is a paragraph explaining how the results from this study helped develop the new question:

○ Training (What Type) - More in-depth questions on specifically what types of training they want and need. The teachers would get a list of possible training options (after school, one-on-one, mentor-based, online etc). They would 
rank which methods they prefer. After the question, an open-ended question would prompt them to discuss training methods.

This question was based on the study showing that a percentage of the teachers did not get the training that they needed or wanted. The purpose of this question is to actually find out what type of training they want to help them succeed in technology integration.

- Training (What They Want to Learn) - A list of main training topics would be included (Whiteboard, United Streaming, Tech Steps), with the teachers responding to what degree they would need/want training on these areas. They also could add additional areas not listed. After the question, an openended question would encourage them to further elaborate on types of training.

This question was based on the study showing that the teachers want more training but it was not clear exactly what they wanted to learn. Many of the teachers just said "yes" they want training. By providing specific areas, it could help focus the staff development training to better match the needs of the teachers. Possibly this could allow the staff to learn about areas that are relevant and interesting to them, rather than always offering whole-group training that is not always specific to what every individual needs.

- Time - This question would help guide what types of activities the teachers need time to do. There could be suggestions on ways to provide time (such as providing substitutes for classes, planning time scheduled for technology, allowing comp time for after-school training, and alternative ideas). The open-ended question would allow teachers to suggest ways that they can make time for the technology. 
Time was a big factor for the teachers, but just saying there is not enough time does not solve the problem. There will always be areas in education that take time during a teacher's busy day. By developing some understanding of what type of time the teachers need may help to change the way things are done to allow more time for technology integration.

○ Support - What type of support do the teachers want? This question would list several different formats (TIS teachers, Technology Contact teachers, mentor programs, one-on-one support in classroom, etc.) The teachers could respond to these questions and give a better understanding of what they need to succeed. At the end an open-ended question would allow the teachers to respond to what support they receive and what they do/do not want in regards to support.

The study showed that teachers want support after the training. Some teachers responded that they learned something new and were sent back to the class with no help. This question would help guide what types of support the teachers need. It could also provide the county with an understanding of how they can best allocate their resources in regards to support issues.

○ Technology Usage - This question would remain similar to questions 10 and 11 in the 2007 survey. New technologies could be added to the list as they become available in the schools. The open-ended question would address what new technologies teachers would like to have in the schools. To current questions 10 and 11, a column should be added that says "Would like to be trained." 
Knowing how the technology is being used and to what degree, would be beneficial to the school and the county when it comes to budgeting for new technologies. This knowledge could also be useful for seeing which technologies are not being utilized as much as they should be and for looking into why they are not being used, possibly because of a need for training.

○ Computer Usage - This question would expand upon the survey question asking how often they use computers at school. This question would break down the different activities that a teacher could use the computer for (lesson planning, grades, student activities, professional development etc.)

The initial question on computer usage just looked at how often they use computers, not for what types of activities they used the computers. This would help to see for whom the computers are being used and if these areas of usage were beneficial to the overall school goals. If the results would show that the teachers are spending most of their time looking up curriculum materials, possibly setting up a data-base of useful sites would save the teachers time from having to find everything themselves. The teachers should not have to "re-invent the wheel" for each lesson by having to do searches for new material, if there are already many wonderful websites that other teachers in the school (or county) are already using.

- Impact - This question was an open-ended interview question that looked at the overall impact of technology. Keeping this question on a future survey would allow the teachers to discuss which technologies have had the most impact and why they feel that have had so much impact. 
This question provided valuable information on not just what the teachers were doing, but what made an impact on the schools. Continuing to look at this would help see where the technology focus is and what teachers have fully integrated and adopted into their teaching.

- Future of Technology - By making this interview question an open-ended question on the survey would increase the number of responses and would allow the teachers to indicate where they perceive technology is gearing towards. This could be set up as a "short-term" future, such as what types of things they would like to see in the next few years and/or a long-term goal for which to strive.

This question provided some interesting viewpoints on where the technology is going but only the interviewees were asked to respond. Including this query as an open-ended survey question would expand the responses and could help to focus the future goals of the school based on the visions of the faculty or even to think beyond the way the schools are run at the time. To become $21^{\text {st }}$ century learners, the students need to know how to do things that are not even created today. Looking at the future helps take steps in that direction.

Survey Method Analysis: This new survey could be used at ABC Middle School, but would not be unique only to this school. These questions would be things that all public schools would need to examine to help implement technology integration. The issues like time, training, support, impact, and future of technology are areas that need to be looked at throughout the school system. 
Many of the questions would be looked at in regards to frequency analysis. Charts and tables would be created to help summarize the various areas. Frequency charts such as bar graphs and pie charts help break down the teachers' responses. The quotes and open-ended question would help to fill in the blanks from the analysis. These studies would be analyzed as a tool to help develop an environment that is more friendly to technology integration in the schools.

By conducting this new study in many different grade levels and schools, it could provide a good instrument for change at the county level. If all schools in the county are addressing a need for a certain type of training, the county could then use the results and provide that training. The study could also compare the schools across the board and see how the technology usage differs among the schools. If one school shows a higher level of usage of one particular technology, the researcher can look at what that school is doing differently. What can the other schools learn from that school to help them improve? What suggestions can be developed to help make more time for technology? How do other schools address these issues? Working with the technology integration should not be done independently at each school. The "best practices" for technology are just being developed and modified and there is still much to be learned by working together to provide the best situation for all students.

Technology and Professional Development. What types of training should the schools provide for the teachers and what type of support do they need to implement the training?

The issue of training has been discussed several times in the study. For the training to have full potential it has to be something that is relevant for the teachers. It 
has to be structured in a meaningful way that encourages and excites the teachers by making it learner-centered and relevant to what they are doing in their classroom.

By using results from the survey the administration can help develop a list of potential training workshops for the teachers. Possibly this may mean having smaller groups of teachers learning about content-specific lessons instead of mandated whole group sessions on general topics. Maybe on staff development days the teachers can have a list of training topics and choose a topic that most will suit their interests, much like a professional conference setting.

Since there is not enough time during the school day to provide training on a regular basis, the county should look at ways to provide stipends or other incentives for the teachers to attend. Several incentive areas were discussed earlier in this paper.

During training workshops, the instructor should provide hand-outs, websites or other ways to get help after the training is over. Many times the teachers will forget how to do something and not have time to figure it out when they return to the classroom.

The training does not have to all be taught by the county either. There are other training resources, such as University classes, distance learning classes, seminars, and community college classes. Providing information about these other resources could help them find training on areas that they desire.

Support for the teachers is also essential as they progress into using more instructional technology. As mentioned earlier, there are many ways that the schools can provide support, such as TIS teachers and Technology Contact teacher. Other ideas such as a technology hotline where teachers can call in with technology questions would also be helpful. Many times having someone to help them use the technology and provide 
support and encouragement is what they need to feel comfortable on their own. Using a new technology can be intimidating when the teachers are in a classroom of technology savvy students. Teachers do not want to feel "stupid" in front of their class.

The area of technology repair is also essential to keep the technology integration up and running. If the computers break down, get a virus or have some other pitfall, it is often overwhelming to the teacher. Having adequate repair support is important to keep the technology in the classrooms. If the teachers feel the technology is not reliable, they may choose to not use it.

This study revealed that several teachers feel they need a full-time teacher at the school whose main focus is to provide technology support. This could be anything from team-teaching, upkeep of technology, helping to find relevant learning materials, training teachers on new technology, and providing an overall understanding of the technology needs of the school.

Another way that the county could be supportive is to provide online support networks for the teachers. Teachers, especially in the older grades, are not able to share ideas with others since they may be the only one teaching that subject area at that grade level. The county could support a database and/or a listserv for teachers to share information where they can go to for assistance and help. Teachers working collaboratively would help the teachers feel supported and provide an outlet to talk to other professionals in other schools. A teacher support group would be of minimal cost but the benefits would be great as the teachers can see what others are doing and share ideas with each other without even leaving their classrooms. 


\section{References}

Barlow, D. (2005). The teachers' lounge: PowerPoint deep. Education Digest, 70(8) 63-67.

Bitter, G. G. (1994). Training prospective elementary mathematics teachers using interactive video. Computers in the Schools, 11(1), 5-20.

Bowker Publishing. (2006). Survey shows professional development is driving tech. Electronic Education Report, 13(15), 4-5.

Bradley, G. (1997). Computer experience, school support and computer anxieties. Educational Psychology, 17(3), 267-285.

Burrall, B., Dillard, L., Robertson, J., \& Taylor, L. (2005) Governors’advisory Council for educational technology. Retrieved November, 2007 at http://www.wvgovdact.org/comittees/professional-development.htm.

Bush, G. (2005). Logging on to staff development. T.H.E. Journal, 32(11), 14-18.

Christensen, R. (2002). Effects of technology integration education on the attitudes of teachers and students. Journal of Research on Technology in Education, 34(4), 411-434.

Connell, M. L. \& Johnson, D. L. (2004). The view from outside: 2000-2003. Computers Schools, 21(1/2), 165-183.

Coley, R. J., Cradler, J., \& Engal, P. K. (1998). Computers and classrooms: The status of technology in U.S. schools. Policy information report. Princeton, N.J: Policy Information Center, Educational Testing Service. 
Daughterty, M.K.\& Boser, R. A. (1993). Professional Development for Technology Education: Results of a National Study. Council on Technology Teacher Education, Reston VA (Eric Document Reproduction Service no. ED 368 937).

Eaton, C. (2005). Sparking a revolution in teaching and learning. T.H.E. Journal, 31(1), $20-24$.

Friedman, D. \& Erickson, K. (2000). Technology alliance survey: A follow up analysis of technology in Washington schools in 2000. Retrieved Oct. 2, 2006 from http://www.technology_alliance.com/pubspols.teched_analysis2000.html.

Gartner Inc. (2003). A report and estimating tool for K-12 school districts: Utah district case study. Retrieved Oct. 2, 2006, from http://classroomtco.cosn.org/2003 case studies/utah.pdf.

Groves, M. M. \& Zemel, P. C. (2000). Instructional technology adoption in higher education: An action research case study. International Journal of Instructional Media, 27(1), 57-64.

Hanson, B, Burton, D, \& Guan, G. (2006). Six concepts to help you align with NCLB. Technology Teacher, 66(1), 17-20.

Hutchens, S. \& Cronin, C. (2004). The effects of technology training on college faculty and pre-service teachers' technology skills. Paper presented at THE Forum, Louisiana State University, April, 2004.

ISTE. (2003) Making it happen. Retrieved March 26, 2007, from http://iste.org Kopkowski, C. (2006). Ready to upgrade? NEA Today, 24(6), 24-32. 
McLester, S. \& Poftak, A. (2005). Celebrating 25 years 1980-2005. Technology and Learning 26(2), 35-37.

MCS. (2007). Professional Development Opportunities. (September 1, 2007) retrieved

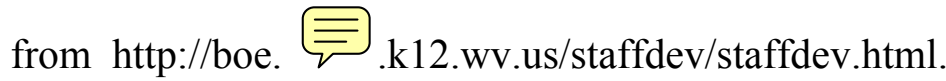

National Center for Education Statistics. (2005) Search for Public Schools website. (March 26, 2007) retrieved from http://nces.ed.gov/.

O’Connell, J. \& Phye, G. (2005). Creating strategies for improved teaching and Learning. T.H.E. Journal, 32(12), 26-29.

Patton, M. Q. (2002). Qualitative research and evaluation methods: (3 ${ }^{\text {rd }}$ Edition). California: Sage Publications.

Reed, M. W., Ervin, J. R., \& Oughton, J. M. (1995). Computers and elementary education students: A ten year analysis. Journal of Computing in Childhood Education, 6(1), 5-24.

Rovai, A. P.,\& Childress, M. D. (2002-2003). Explaining and predicting resistance to computer anxiety reduction among teacher education students. Journal of Research on Technology in Education, 35(2), 235-226.

Ropp, M. (1999). Exploring individual characteristics associated with learning to use Computers in pre-service teaching preparation. Journal of Research on Computing in Education, 31(4), 402-424.

Schacter, J. (1999). The impact of education technology on student achievement: What the most current research has to say. California: Milken Family Foundation. 
Schmitt, C. (2002). Technology in schools suggestions, tools, and guidelines for assessing technology in elementary and secondary education. Washington D.C.: National Center for Education Statistics.

Shaw, T. (2006). Simple questions, difficult answers. Multimedia and Internet @ Schools 13(1). 38-40.

Shick, R. (1996). Implementation of Technology in the Classroom Master's Practicum Report: Nova Southeastern University. (Eric Document Reproduction Services no. ED 394-516.)

Smith, S.D. (1986). Relationship of computer attitudes to sex, gender-level, and teacher influences. Education, 106(3), 338-344.

Tashakkori, A. \& Teddlie, C. (2003). Handbook of mixed methods in social and behavioral research: California: Sage Publications.

Taylor, L. M. Casto, D. J. \& Walls, R. T. (2007). Learning with versus without technology in elementary and secondary schools. Computers in Human Behavior 23(1), 38-40.

Turner, P.M. (1996). What help do teachers want and what will they do to get it? School Library Media Quarterly, 24(4), 208-211.

U.S. Department of Education. (1999). Teacher quality enhancement grants. Retrieved October 20, 2006, from http://www.ed.gov/programs/heatqp/index.html U.S. Department of Education. (2001). No Child Left Behind: Washington, D.C. Wang, L. Y. (2002). How teachers use computers in instructional practice - four examples in American schools. International Journal of Art and Design Education, 21(2), 154-163. 
West Virginia Department of Education. (1998). West Virginia report cards 1997-1998. Retrieved March 26, 2007, from http://wvde.state.wv.us/data/report_cards/1998/ West Virginia Department of Education (2005). Caperton technology award highlighted at state technology conference. Retrieved April 1, 2007, from http://wvde.state.wv.us/news/

West Virginia Department of Education (2006). West Virginia report cards 2005-2006. Retrieved April 1, 2007, from http://wvarchives.k12.wv.us.

West Virginia Department of Education (2006). Digital Divide Report. Retrieved March 26, 2007, from http://wvde.state.wv.us/data/digitaldivide/2006/html.

West Virginia Department of Education (2007). Enhancing education through competitive application. Retrieved September 1, 2007, from http://www.k12.ww.us/eet/R6App.doc.

West Virginia Department of Education (2007). WVDE technology standards and objectives. Retrieved September, 2007, from http://boe.mono.k12.wv.us/Resources/techskills.htm.

West Virginia Department of Education (2008) West Virginia board of education: Educational technology for $21^{\text {st }}$ century learners: Strategic work plan 2005-2008. Retrieved March 20, 2008 at http://wvde.state.wv.us/techworkplan. XYZ County Schools website. (Nov. 20, 2005) retrieved from http://boe. $\overline{\bar{v}}_{\text {.k12.wv.us/district info/index.html }}$

Zuckerman, M. B. (2005). Classroom revolution. U.S. News and World Report, 13(13), 68. 


\section{Appendix A}

Research Report from 1997 Study

A Survey Assessing the Readiness of Classroom Teachers from a West Virginia Public School in Integrating Computers and Technology into the Classroom

\section{Melinda Marple}

Spring, 1997 
A Survey Assessing the Readiness of Classroom Teachers from a West Virginia Public School in Integrating Computers and Technology in the Classroom.

\author{
By Melinda Marple
}

$\underline{\text { Introduction }}$

Teacher training plays a significant role in the implementation of computers and technology in the schools. Without developing appropriate in-service in technology we will not see the benefits that this new technology has to offer. This proposal was designed to survey the teachers at a West Virginia School in assessing their readiness to identify the baseline information which can be used to help develop future training programs.

\title{
$\underline{\text { Review of Literature }}$
}

Many factors determine how effective computers will be integrated into the classroom. One of the key areas that need to be addressed in order to have a successful technology program in the schools is teacher training. Several factors related to teacher training that can have an effect on the implementation of computers include the level of computer anxiety, prior computer experiences, and the average age and experience of the population.

\section{Effects of Teacher Training}

Computer technology should be introduced into the schools through integration into the curriculum and not seen as just a separate entity. The only way for this to happen is to educate teachers in using computers and technology. They need to feel comfortable in using this new technology tool and see the value of integrating computers into their curriculum. "The effective implementation of a technology education program requires that the teacher develop new technological skills in addition to changing educational philosophy, curriculum, and instructional methods" (Daughterty, p.9).

From the research, one factor that was clearly represented was the need to have in-service programs that are relevant to the teacher's specialization area. Results from a 10 -year study on computer training for pre-service teachers recommend that "majorspecific courses incorporate major-specific computer uses, rather than all students receiving computer-related instruction via general, computer courses" (Reed, Ervin \& Oughton 1995, p.22). Results like this can also carry over to practicing teachers. Providing generic computer training program for everyone limits the scope of the areas covered in the in-service. Content specific software and applications can not be as fully discussed in a whole group training program as it could in a specialized program.

Results from one study showed that "(1)ess than a quarter of the teachers that use the computer for teaching has integrated the use of the computer in their curriculum. There is not a single subject area that has integrated the computer fully" (Doornekamp \& Carleer, p.190). With continued in-service training, this trend should continue to 
increase. This importance is in the integration of the computer into the classroom. Without true integration, this technology will not be used to its full potential.

Doornekemp and Carleer's (1993) research showed that computers were not frequently integrated into the classroom; when it was used, it was on a supplementary level only. One constraint found in the integration was the lack of courseware packages to match the specific curriculum and scheduling lab time to coordinate with appropriate lessons. When implementing technology, these factors need to be taken into consideration.

One way to assist in the implementation of technology would be to develop inservice training or programs or in-service that is relevant. It should provide real-life, hands on training that shows good modeling and practice for the implementation of computer technology to be effective. A study done by Bitter (1994) discussed the importance of having "real life" experiences in teacher training programs. In his study the participants were shown a video system modeling actual classroom teachers using the teaching strategies they were learning. Results from surveys taken after this workshop showed positive responses to this teaching strategy. The participants learned novel teaching strategies as well as positive and negative examples of teaching strategies used in their area.

Teachers are always stressed for time. When providing in-service training, it is crucial to make the information meaningful and teach the teacher how to learn more about the technology. By teaching strategies instead of skills, the training will be more meaningful for the teacher to use in the curriculum. This is illustrated in the research by Jurkat, Morris, Friedman, and Pinkham (1991) which demonstrated that teachers need to feel free to explore ways they can incorporate the technology into their own teaching styles and used the "time as one of the essential resources provided to them which made it possible to reach their goals" (Jurkat et. al, p. 11). An added bonus of workshops like this "not only provided time to learn software, but it also provided time for teachers from the same school to discuss logistics and strategies to integrate computers in their curricula" (Jurkat et.al, p.11).

Another factor that plays a role in teacher training is being able to offer the actual training courses. It was reported that $55 \%$ of the respondents in a study on professional development for technology education had a coordinated program for technology inservice in their state (Daughterty, 1993). The results also indicate that many universities and colleges appeared to be active partners in states with these coordinated in-service programs (Daughterty). With schools on tight budgets and limited personnel for training, this help from colleges and universities is a necessity.

Research conducted on the cooperation between universities and primary and secondary schools showed that the university involvement was an important factor for technology training in-service to teachers (Organisation for Economic and Cooperation Research, 1992). One way the universities are helping is by providing in-service training courses to the teachers already in the field. Another area that is being expanded is by 
training at the pre-service teaching level. In the study by Daughterty (1993) it was shown that, "Colleges and universities that are active in pre-service technology teacher preparation are actively involved in in-service and professional development for classroom teachers: (Daughterty, p.16).

\section{Computer Anxiety/Attitudes}

There has been a strong correlation between computer experience and computer anxiety. Until recently, few people had access to a computer on a regular basis to allow them to become even partially computer competent. In a study evaluating technology integration, it was found that only $30 \%$ of the teachers surveyed had computers in their homes and only $29 \%$ of them use computers with their students. One reason for this could be that only a little over half of those surveyed felt comfortable using the computer. (Mahamood \& Hirt, 1992).

Research shows that prior experience and training have a positive effect on decreasing computer anxiety. Reed and Liu (1994) found that the students in the Hypercard and Basic groups decreased their computer anxiety. They claim that it is not surprising because many students have shown that computer anxiety can be significantly decreased even after their brief exposures to computer instruction (Reed \& Liu, p.12).

Similar results were found in the research done by Shick (1996) who found that "(a)fter training, the staff had a very positive attitude towards the integration of technology into the classroom curriculum (p.4). Shick's research also showed that "(a)s knowledge of computers increased, the teacher began to feel more comfortable when planning the presentation of classroom curriculum using a computer station (p.45).

With a strong research base on computer anxiety correlating specifically with prior computer experience, we need to focus our attention on allowing experience to develop.

\section{Effects of Prior Computer Experience/Training}

It was found that having training and background in computers affects the overall attitude towards use of computers, use of the computers on the job and at home, and the formation of technology integration plan, (Mahmood \& Hirt, 1992) With prior experiences having such an important role in the integration of computers into schools, we need to review what research has to say about these effects.

Brummelhuis and Plomp (1994) reported that $60 \%$ of participants who were noncomputer users could not see the value of incorporating computers into their curriculum. The authors interpreted this to mean that, "Many teachers first want to gain more knowledge about the possibilities of the computer for educational ends before substituting the security of their teaching routines by the insecurities which accompany the introduction of the computer" (Brummelhuis \& Plomp, p. 298). On the positive side, Shick (1996) found that, "Computer training showed significant increases in computer utilization plus an extended to a high level of curiosity as to other technological attributes 
the computer can offer to the curriculum presentation (p.46). An additional idea that could be considered when providing the training is based on a study by Paramean and Slovaceks (1995). They found that the students were more likely to prefer working with the computer platform when they were trained via the introductory course.

The 10 year study by Reed, Ervin and Oughton (1995) showed that elementary education students starting the program in later years had more computer experience and lower computer anxiety than those during the early years of the study. It is reasonable to assume that as computers become more a part of our everyday lives, this trend will continue to hold and we will see more pre-service and practicing teachers coming to the schools with a better background in computers. At this time computer in-service training will take on a different approach, away from basic training to more sophisticated applications.

At this time, though, the average teacher has not had the pre-service training nor had experience using computers in their own schooling. The demographics from a national study reveal that "the average in-service participant was between 31-40 years old, have 5-12 years of teaching experience, had a Master's degree, and taught in the high school setting. (Daughterty, 1993, p. 17). For this average population we need to focus on the basic training approaches until they feel comfortable with this technology.

Providing computer training is not enough. Before teachers even begin the training program, they come with computer anxieties and attitudes. These areas must be addressed before beginning the implementation of computers in the classroom.

\section{$\underline{\text { Summary of the Literature Review }}$}

Teachers trained in the use of technology and computers were shown to have a significant effect on the success of the implementation of computers and technology into the classroom. By developing appropriate in-service training, in cooperation with universities and colleges, teachers will gain the experience needed to feel more comfortable using computers. While teachers gain computer experiences that are relevant to their area, their level of anxiety towards computers decreases and their confidence rises. These factors are the perfect ingredients for positive computer implementation into the curriculum.

\section{Purpose of the Study}

Schools across West Virginia are joining the country in purchasing and incorporating technology and computers into the classroom. Having this new technology available to classroom teachers, however, does not automatically mean that they are willing or able to use it. To the contrary, research clearly suggests that there are considerable variations among teachers in their readiness to adopt new computer-based technologies. Variables include their level of computer literacy, training, and experience; their attitudes regarding the comfort levels in working with computers; and their awareness of specific computer applications. 
It is proposed that a sample of teachers be surveyed to assess their readiness to incorporate the new technology within their teaching activities. Additional information will be gathered to determine their specific needs for in-service training in this area and what types of training is already being done. More specifically, this survey will seek to measure their knowledge, attitudes, and previous experiences with the new telecommunication capabilities and their comfort/anxiety level in working with computers in general.

\section{$\underline{\text { Research Question }}$}

What is the readiness of classroom teachers from ABC Middle School to integrate telecommunications within their teaching activities?

Type of Study: Descriptive

\section{$\underline{\text { Dependent Measures }}$}

- Computer Anxiety scores determined by mean differences and frequencies of survey responses.

Independent Measures

(Mean Differences of)

- Years of Teaching Experience

- Teacher's Area of Specialization

- Age Range of the teacher

(Frequencies of)

- Prior Computer Experience

- Prior Computer Training

\section{Alternative Hypothesis}

There are varying levels of readiness among classroom teachers from $\mathrm{ABC}$ Middle School in integrating telecommunications within their teaching activities.

\section{Null Hypothesis}

Classroom teachers from ABC Middle School have a uniform level of readiness to integrate telecommunications within their teaching activities.

\section{$\underline{\text { Validity and Reliability }}$}

This survey has been modified, but the validity and reliability would be expected that it would be comparable.

To test for validity of the instrument, people who were competent in computers and teaching strategies will be asked to review the instrument and respond. 
To test for reliability, a group of similar population will be asked to pilot the test. This will test for consistency of the results. The instrument also provides for some internal reliability by having some questions that are similar in nature.

The study falls within the guidelines of an exemption review since the subjects of this review are adults participating on a voluntary basis. The focus of this study does not deal with any sensitive information.

\section{$\underline{\text { Sample Situation Statement }}$}

ABC Middle School, West Virginia, has recently upgraded its telecommunications capabilities to provide access to the Internet. Having this new capability available to classroom teachers, however, does not automatically mean they are willing or able to use it. To the contrary, research literature clearly suggests that there is considerable variation among teachers in their readiness to adopt new computer-based technologies. Variables include their level of computer literacy, training and experiences; their attitudes regarding the comfort levels in working with these variation, the school's computer teacher, Dr. K.M., is planning to conduct an in-service training program for all classroom teachers on the integration of the new telecommunications capabilities within the middle school curriculum.

To assist in the design and development of their training program, it is proposed all middle school teachers by surveyed to assess their readiness to incorporate new telecommunication capabilities within their teaching activities, and to determine their specific needs for training in this area. More specifically, this survey will seek to measure their knowledge, attitudes, and previous experiences with the new telecommunications capabilities, and their comfort/anxiety level in working with computers in general. Information obtained from this survey should be useful to Dr. Schweiker Marra in the design of her In-service teaching program.

\section{$\underline{\text { Procedures }}$}

All teachers from ABC Middle will be asked to respond to this survey. The surveys will be distributed to the participants through their school mail boxes with a cover letter providing information and instructions. A return box will be provided for the teachers to return the surveys anonymously.

\section{$\underline{\text { Analysis of Data }}$}

Variables that will be evaluated include computer computer/anxiety level, prior computer/technology experience, prior computer/technology training, age range of teachers, years of experience, and the teacher specialization areas. Data will be analyzed by doing a multiple regression analysis to determine relationships among the different variables. For the demographic information (age of experience and age range) numbers will be assigned to the categories in order to properly run the regression. 
$\underline{\text { Key Variables: }}$

\section{$\underline{\text { Results }}$}

Computer Literacy (Question 1 and Question 9)

Computer Comfort/Anxiety Level (Question 8)

Prior Computer/telecommunications training and experiences (Questions 1-7)

Awareness of telecommunication applications (Question 9)

Age of teachers/years of experience (Demographics)

Teachers Area of Specialization (Demographics)

\section{Computer Anxiety/ Prior computer knowledge}

When doing a multiple regression for question 1 (How Would you Rate your Knowledge of Computer Technologies, and Question 5 (How will you assess your current level of comfort in using computers. There was a relationship found between these two variables, indicating that computer anxiety had a correlation with prior computer knowledge.

(See Attached 1)

\section{$\underline{\text { Age/Computer Usage }}$}

In question 4 I was looking at the differences in the age of the participant and how many hours they use the computers at home. In these results, the age group over 45 used the computer more than those participants under 30 . While these results may seem surprising based on the literature review, it is important to take into consideration that there was only 1 participant in the lower category. Plus, the computer teacher was in the over 45 category, so that could skew the results as well.

$\underline{(\text { See Attached 2) }}$

\section{Computer Comfort in Willingness to Adopt Technology}

In looking at teacher readiness to adopt the technology, I asked questions on questions such as "All Classrooms Should be Equipped with Computers", All teachers should learn to use the Internet" and "All students should learn to use the Internet" With all three questions well over a majority agreed or strongly agreed. This shows that the teachers feel it is important to have the computers in the classroom, and that they feel the students and themselves should learn to use them.

(See Attachment 3)

\section{Computer Training and Knowledge}

When asked "How would you rate your knowledge of computer technologies, the frequency chart shows that a majority of the participants felt they had a fair amount of knowledge. When asked to indicate the level of training they have received on computers as an instructional tool, a low medium frequency was indicated. These results show that the participants have limited training and knowledge when it comes to 
computer technologies. When comparing the two graphs, it also shows that there is a similar comparison in training and knowledge. (See Attachment 4)

Telecommunication Training and Knowledge

Similar results were found when asked about knowledge of the Internet/telecommunications "How would you rate your knowledge of telecommunications/Internet applications of computers" and the training received "Indicate the level of training you have received on the use of telecommunications/Internet as an instructional tool. These results show a low/middle frequency for knowledge and an even lower frequency for telecommunications training. These results were interesting in showing that the teachers felt more knowledgeable about telecommunications than their training would indicate. (See Attachment 5).

\section{Discussion}

At this time, teachers at ABC Middle have had limited training in computers and telecommunications. They had a moderate anxiety about using the computers which had a correlation to their prior computer usage. Yet, the teachers showed a strong willingly to use the computers, with a majority saying that they agreed or strongly agreed to having computers in the classroom and having teachers and students learn to use the computers. With this willingness to learn the new computer, and the importance of computer training, anxiety and prior knowledge of computers, it is important that these teachers are given appropriate training to help them adopt the computer technology into their classroom curriculum.

The area of telecommunications/Internet training for this group was shown to be a weakness. As part of a follow-up to this study, I offered to provide an Internet in-service for this group to thank them for being part of this study.

As computer training and Internet training become more widely offered, I would expect to see the continuing correlation of computer knowledge and computer anxiety to continue. When the teachers are more confident in the computers, their anxiety will decrease and they will be more comfortable using the computer more.

\section{$\underline{\text { Conclusion }}$}

Results from the survey will help provide a guideline for preparation for future teacher training courses. For additional studies, similar surveys can be administered over a period of time to determine in the population overall is beginning to feel more comfortable about using the computers as part of their curriculum. 


\section{$\underline{\text { References }}$}

Bitter, Gary G (1994). Training prospective elementary mathematics teachers using interactive video. Computers in the Schools, 11(1) 5-20.

Brummelhuis, Alfons ten; \& Plomp, Tjeerd. (1994). Computers in primary and secondary education: The interest of an individual teacher or a school policy. Computers and Education 22(4). 291-299.

Daughterty, Michael K.; \& Boser, Richard A. (1993). Professional Development for Technology Education: Results of a National Study. Council on Technology Teacher Education, Reston VA (Eric Document Reproduction Service no. ED 368 937).

Doornekemp, Gerard B.;\& Carleer, Gerrit J. (1993) Constraints on the integration of computers in the curriculum. Journal of Technology and Teacher Education, 1(2) 181 194.

Hunt, N. B.,\& Roy M. (1993). Teacher education students' attitudes towards using computers. Journal of Research and Computing in Educaiton 24(4). 487-497.

Jurkat, M. Peter; Morris, Lori V.; Friedman, Edward A; \& Pinkham, Roger S. (1991). University-Secondary school cooperation for inservice training and computer use for mathematics instruction.. Journal of Computing in Teacher Education 7(4) 8-15.

Mahamood, Mo Adam; \& Hirt, Shirley A. (1992). Evaulating a technology integration causal model for the K-12 public school curriculum: A LISREL analysis University of Texas, El Paso, TX. (Eric Document Reproduction Service no. ED 346847).

Oraganisation for Economic Cooperation and Development; Centre for Educational Research and Innovation (1992). Education and new information technologies teacher training and research; A survey of co-operative projects between universities and schools. Paris, France. (Eric Document Reproduction Service no. ED 350-974).

Pardamean, Bens\& Slovaceks, Simeon (1995). The influence of training platform on subsequent computer preferences. Journal of Computing in Teacher Education, 11(2). 19-25.

Reed, Michael W.;\&Liu, Min (1994) The comparative effects of BASIC programming versus Hypercard programming on problem-solving, computer anxiety, and performance. Paper presented at the Annual Meeting of Eastern Education Research Association, Hilton Head, SC. 
Reed, Michael W.; Ervin, Joseph R. \& Oughton, John M. (1995). Computers and elementary education students: A ten year analysis. Journal of Computing in Childhood Educaiton, 6(1). 5-24.

Shick, Robert. (1996). Implementation of Technology in the Classroom Master's Practicum Report: Nova Southeastern University. (Eric Document Reproduction Services no. ED 394-516. 


\section{Attachment 1}

Question 1

How would you rate your knowledge of computer technologies?

$\begin{array}{lllll}1 & 2 & 3 & 4 & 5 \\ \text { Poor } & \text { Limited } & \text { Fair } & \text { Good } & \text { Excellent }\end{array}$

Question 5

How would you assess your current level of conflict in using computers?

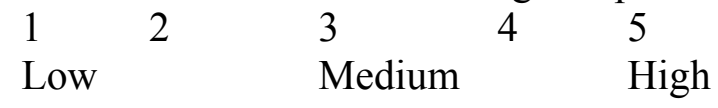

\begin{tabular}{|c|c|c|c|c|c|c|c|c|}
\hline \multicolumn{9}{|c|}{$\begin{array}{l}\text { ANOVA Table } \\
\text { Question } 1 \text { vs. Question } 5\end{array}$} \\
\hline \multirow{4}{*}{$\begin{array}{l}\text { Regression } \\
\text { Residual } \\
\text { Total }\end{array}$} & \multirow{2}{*}{$\frac{D F}{1}$} & \multicolumn{2}{|c|}{ Sum of Squares } & \multicolumn{2}{|c|}{ Mean Square } & F-Value & P-Value & \\
\hline & & \multicolumn{2}{|c|}{7.939} & \multicolumn{2}{|r|}{7.939} & 24.884 & $<.0001$ & \\
\hline & 22 & \multicolumn{2}{|r|}{7.019} & \multicolumn{2}{|r|}{.319} & & & \\
\hline & 23 & \multicolumn{2}{|c|}{14.958} & & & & & \\
\hline \multirow{2}{*}{\multicolumn{9}{|c|}{$\begin{array}{l}\text { Regression Coefficients } \\
\text { Question } 1 \text { vs. Question } 5\end{array}$}} \\
\hline & & & & & & & & \\
\hline & \multicolumn{2}{|c|}{ Coefficient } & Std. & Error & Std. $C$ & Coeff. & t-Value & P-Value \\
\hline Intercept & & 1.195 & & .388 & & 1.195 & 3.081 & .0055 \\
\hline Question5 & & .576 & & .115 & & .729 & 4.988 & $<.0001$ \\
\hline
\end{tabular}

(Knowledge vs. Comfort Level)

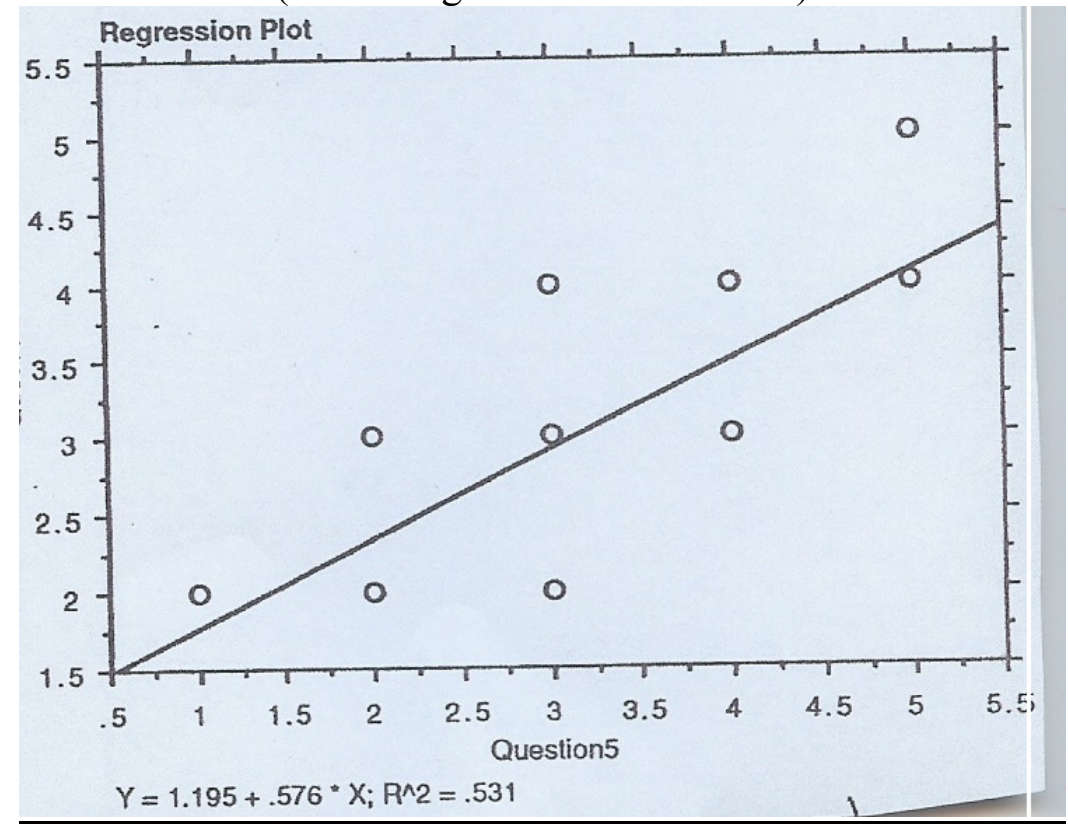




\section{Attachment 2}

\section{(Difference)}

What effect does age have on how many hours/week teachers use the computers at home?

\section{ANOVA Table for Question4}

\begin{tabular}{|c|c|c|c|c|c|}
\hline & DF & Sum of Squares & Mean Square & F-Value & P-Value \\
\hline Age Category & 2 & .916 & .458 & .331 & .7221 \\
\hline Residual & 20 & 27.692 & 1.385 & . & \\
\hline
\end{tabular}

Model II estimate of between component variance:"

2 cases were omitied due to missing values.

Means Table for Question 4
Effect: Age Category
Count \begin{tabular}{r|r|r|r|}
\hline & Mean & Std. Dev. & Std. Err. \\
\hline 1 & 2.000 & & $\bullet$ \\
\hline 13 & 2.846 & 1.144 & .317 \\
\hline 9 & 3.000 & 1.225 & .408 \\
\hline
\end{tabular}

2 cases were omitted due to missing values.

(Frequency of Home Computer use vs Age Range)

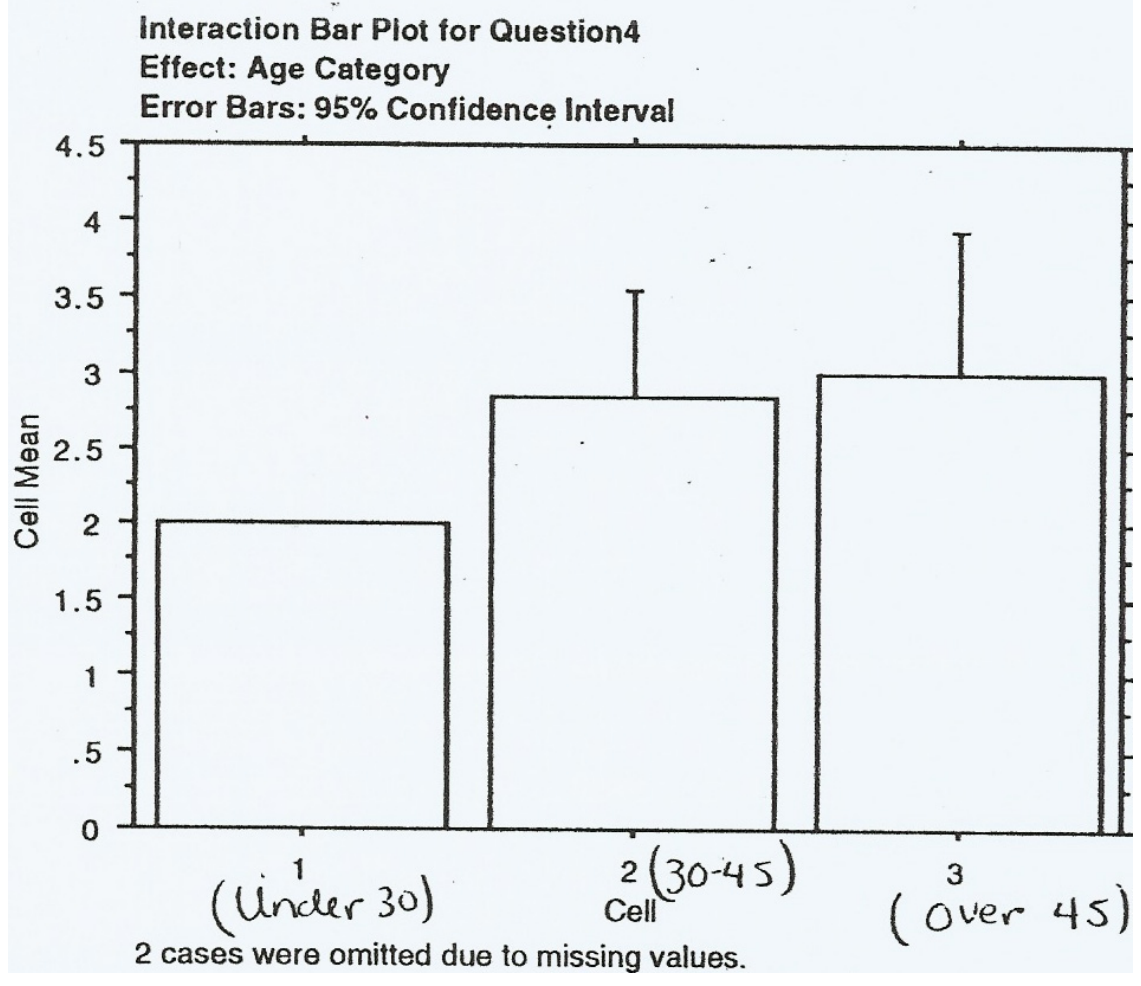




\section{Attachment 3}

Percentage of Teacher Responses to the Questions:

\section{Statistics}

\begin{tabular}{|c|c|c|c|c|c|}
\hline & & $\begin{array}{l}\text { All classrooms } \\
\text { should be } \\
\text { equipped with } \\
\text { computer }\end{array}$ & $\begin{array}{c}\text { All Teachers } \\
\text { should learn how } \\
\text { to use the } \\
\text { Internet }\end{array}$ & $\begin{array}{r}\text { All S } \\
\text { should } \\
\text { to L } \\
\text { In }\end{array}$ & $\begin{array}{l}\text { udents } \\
\text { earn how } \\
\text { e the } \\
\text { rnet }\end{array}$ \\
\hline $\begin{array}{l}\text { N } \\
\text { Mean }\end{array}$ & $\begin{array}{l}\text { Valid } \\
\text { Missing }\end{array}$ & $\begin{array}{r}24 \\
0 \\
3.5833\end{array}$ & $\begin{array}{r}24 \\
0 \\
3.5000\end{array}$ & & $\begin{array}{r}24 \\
0 \\
3.58333\end{array}$ \\
\hline & & $\begin{array}{c}1 \\
\text { Strongl } \\
\text { Disagre }\end{array}$ & $\begin{array}{c}2 \\
\text { Disagree }\end{array}$ & $\begin{array}{c}3 \\
\text { Agree }\end{array}$ & $\begin{array}{c}4 \\
\text { Strongly } \\
\text { Agree }\end{array}$ \\
\hline
\end{tabular}

All Classrooms Should be Equipped with Computers.

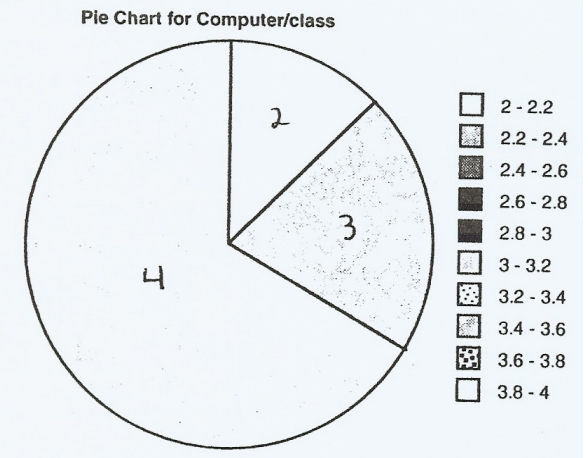

All Teachers Should Learn to use the Internet.

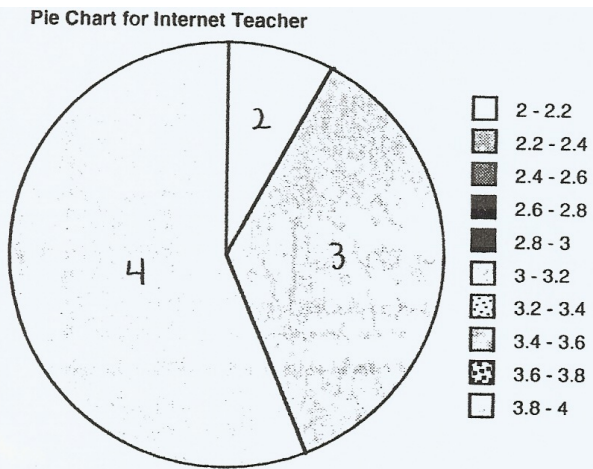

All Students Should learn to use the Internet. 
Technology Integration 194

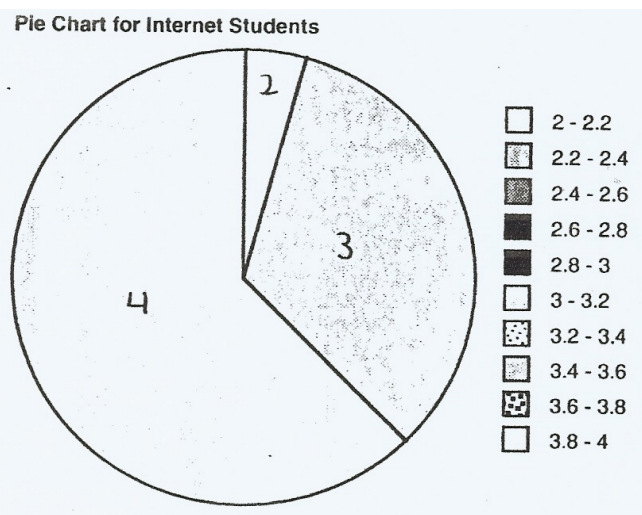




\section{Attachment 4}

How would you rate your knowledge of computer technologies?

1 Poor Limited Fair Good Excellent

(How Many Responses vs. Computer Knowledge Rating)

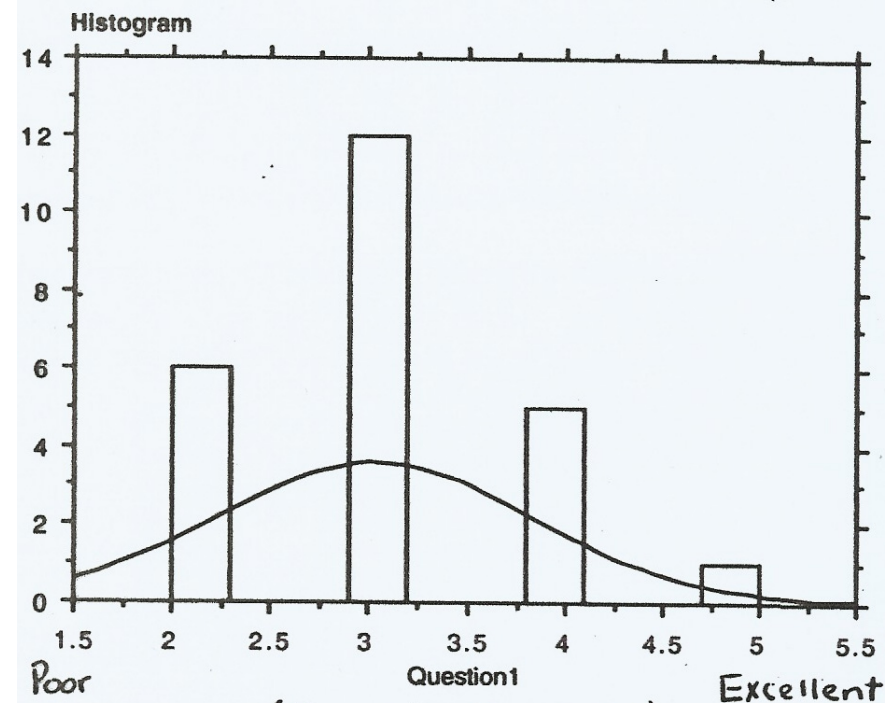

Indicate the level of Training you have received on computers as an instructional tool?

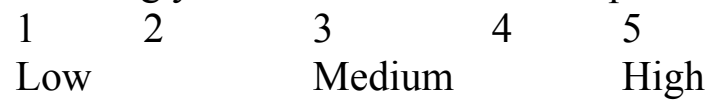

(How Many Responses vs. Computer Training Amount)

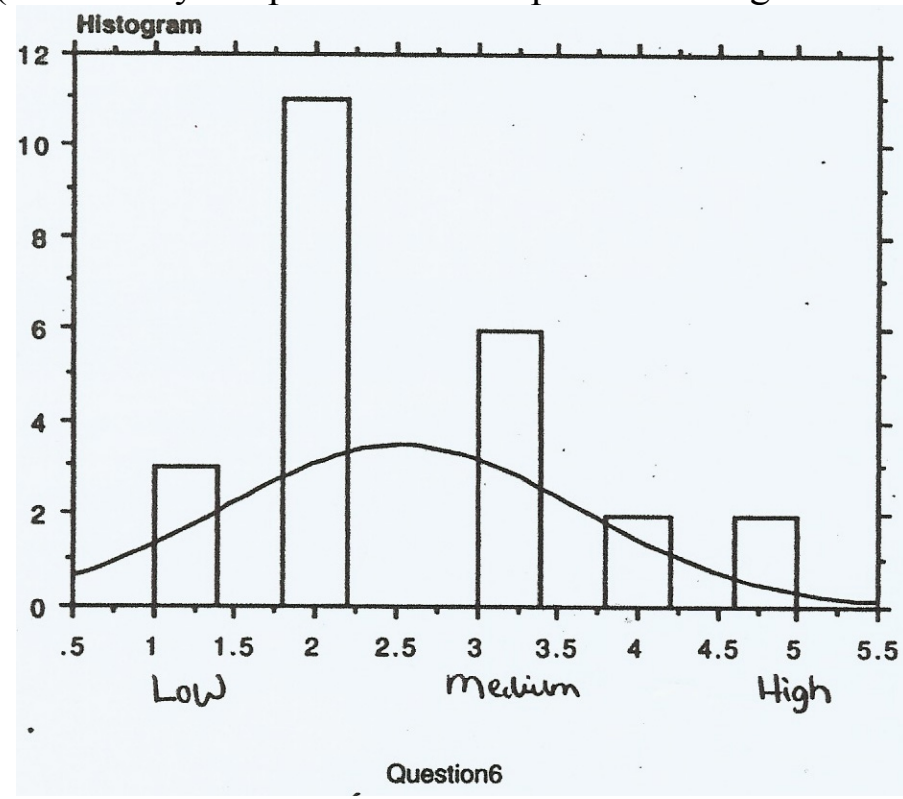




\section{Attachment 5}

How would you rate your knowledge of telecommunications/Internet applications of computers?

$\begin{array}{lllll}1 & 2 & 3 & 4 & 5 \\ \text { Poor } & \text { Limited } & \text { Fair } & \text { Good } & \text { Excellent }\end{array}$

(How Many Responses vs. Knowledge of telecommunications rating)

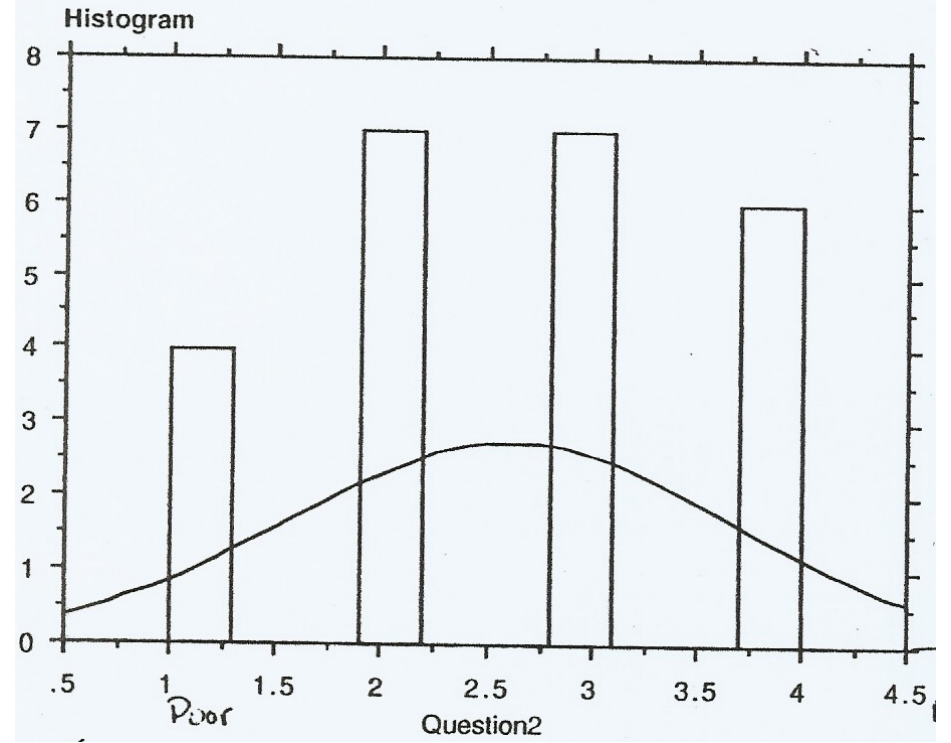

Indicate the level of training you have received on the use of telecommunications/Internet as an instructional tool.

$\begin{array}{lllll}1 & 2 & 3 & 4 & 5 \\ \text { Low } & & \text { Medium } & & \text { High }\end{array}$

(How Many Responses vs. Telecommunications Training Histogram

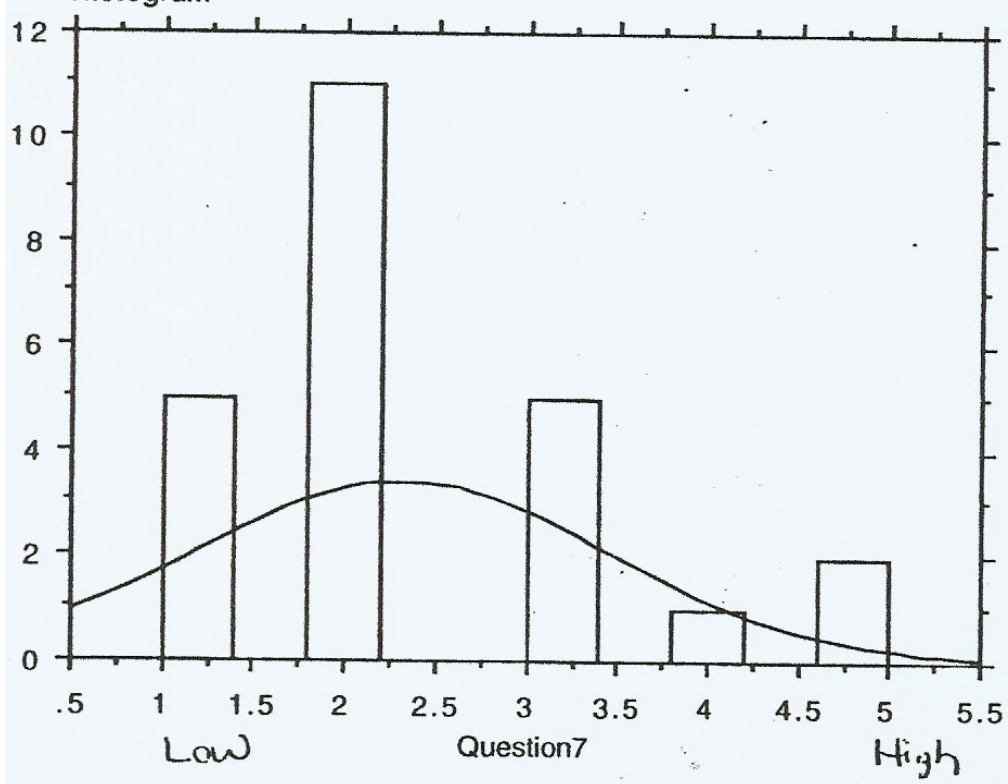


Technology Integration 197

\section{Computer Survey}

Instructions: Please circle the answer that best describes you.

1. How would you rate your knowledge of computer technologies?
Poor
Limited
Fair
Good
Excellent

2. How would you rate your knowledge of telecommunications/Internet applications of computers?

$\begin{array}{ccccc}\text { Poor } & \text { Limited } & \text { Fair } & \text { Good } & \text { Excellent } \\ 1 & 2 & 3 & 4 & 5\end{array}$

3. How often do you use computers at school?

$\begin{array}{ccccr}\text { Never } & \text { Seldom } & \text { Somewhat } & \text { Often } & \text { Very Often } \\ 1 & 2 & 3 & 4 & 5\end{array}$

4. How often do you use computer outside of school?

$\begin{array}{ccccc}\text { Never } & \text { Seldom } & \text { Somewhat } & \text { Often } & \text { Very Often } \\ 1 & 2 & 3 & 4 & 5\end{array}$

5. How will you assess your current level of comfort in using computers?

Low

Medium

High

1

2

3

4

5

6. Indicate the level of training you have received on computers as an instructional tool.
Low
Medium
High
1
3
5

7. Indicate the level of training you have received on the use of Telecommunications/Internet as an instructional tool.

\begin{tabular}{ccccc} 
Low & \multicolumn{3}{c}{ Medium } & High \\
1 & 2 & 3 & 4 & 5
\end{tabular}


8. The following questions relate to your current attitudes regarding computers and the use of computers for teaching and learning. Circle the number that best reflects how you feel.

\begin{tabular}{|c|c|c|c|c|}
\hline $\begin{array}{l}\text { Strongly } \\
\text { Disagree }\end{array}$ & Disagree & Agree & $\begin{array}{l}\text { Strongly } \\
\text { Agree }\end{array}$ & \\
\hline 1 & 2 & 3 & 4 & $\begin{array}{l}\text { I feel self-confident about using } \\
\text { computers for testing and learning. }\end{array}$ \\
\hline 1 & 2 & 3 & 4 & $\begin{array}{l}\text { If feel that too much emphasis is being } \\
\text { placed on the use of computers for } \\
\text { teaching and learning. }\end{array}$ \\
\hline 1 & 2 & 3 & 4 & $\begin{array}{l}\text { I am concerned about having enough } \\
\text { time to learn about computers so I can } \\
\text { use them effectively. }\end{array}$ \\
\hline 1 & 2 & 3 & 4 & $\begin{array}{l}\text { At this time, I am not interested in } \\
\text { learning about computers. }\end{array}$ \\
\hline 1 & 2 & 3 & 4 & $\begin{array}{l}\text { Leaming to use computers will make } \\
\text { me a more effective teacher. }\end{array}$ \\
\hline 1 & 2 & 3 & 4 & $\begin{array}{l}\text { Computer literacy should be a learning } \\
\text { outcome of our school system. }\end{array}$ \\
\hline 1 & 2 & 3 & 4 & $\begin{array}{l}\text { I am overwhelmed about having to } \\
\text { learn to use computers for teaching and } \\
\text { learning. }\end{array}$ \\
\hline 1 & 2 & 3 & 4 & $\begin{array}{l}\text { Computer literacy should be taught in } \\
\text { the computer lab instead of being } \\
\text { integrated into the classroom } \\
\text { curriculum. }\end{array}$ \\
\hline 1 & 2 & 3 & 4 & $\begin{array}{l}\text { All classrooms should be equipped with } \\
\text { computers. }\end{array}$ \\
\hline 1 & 2 & 3 & 4 & $\begin{array}{l}\text { All students should learn how to use the } \\
\text { Internet. }\end{array}$ \\
\hline 1 & 2 & 3 & 4 & $\begin{array}{l}\text { All teachers should learn how to use } \\
\text { the Internet. }\end{array}$ \\
\hline 1 & 2 & 3 & 4 & $\begin{array}{l}\text { I am concerned about what my employer(s) } \\
\text { might expect me to know about computers } \\
\text { and how those expectations might be in } \\
\text { conflict with what I would like to do. }\end{array}$ \\
\hline 1 & 2 & 3 & 4 & $\begin{array}{l}\text { Telecommunications/Internet has limited } \\
\text { application in the subjects I teach. }\end{array}$ \\
\hline
\end{tabular}


Technology Integration 199

8. The following questions assess your current knowledge of computers and computer applications:

What software would you use if you wanted to connect to the World Wide Web?
A. MSDOS
B. Chameleon
C. Netscape
D. Do not know

Which of the following is not part of a computer system?
A. Modem
B. Projector
C. CD ROM
D. Do not know

Which of the following components can be used in place of a keyboard?
A. Printer
B. Mouse
C. Disk Drive
D. Do not know

What is a URL (http)?

A. The name of the computer system you are using.

$B$. The address to the site you are connected to on the Internet.

C. The phone number you are dialing when using a modem.

D. Do not know

Which Internet tool would you use to find information on a certain topic?

A. The online directory

B. A search engine

C. An E-mail address

D. Do not know

Which of the following is not a component of the Internet?
A. Listserw
B. Homepages
C. RAM
D. Do not know 
Technology Integration 200

The Following Questions are about yourself:

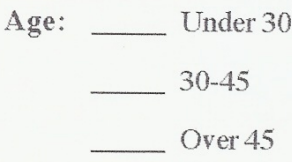

Number of years Teaching

5 and under
$\quad 6-10$
$11-20$
over 20

Areas of Specialization

(i.e. Math, Science, English etc.)

Thank you for you time in completing this survey! 


\section{Appendix B}

\section{Technology Integration Survey (2007)}

Instructions: Please circle the answer that best describes you.

1. How would you rate your knowledge of computer technologies?
Poor
Limited
Fair
3
Good
4
Excellent
5

2. How would you rate your knowledge of the use of Internet applications?
Poor
Limited
Fair
1
2
3
Good
4
Excellent 5

3. How often do you use computers at school?
Never
Seldom
2
Somewhat
3
Often
4
Very Often 5

4. How often do you use computers outside of school?
Never
Seldom
Somewhat
3
Often
4
Very Often 5

5. How do you assess your current comfort level in using computers and computer technologies?
Very Anxious
Somewhat
Very Comfortable
1
2 Comfortable
3
4
5

6. How much training have you received in using the computer as an instructional tool?
Little or no
Moderate training
Extensive training training
2
3
4
5

7. How much training have you received on using the Internet as an instructional tool?

Little or no

Moderate training

Extensive training training

1

2

3

4

5

8. How do you feel about the overall amount of instructional technology training you have received?
Less training needed

1

2
Just enough

training received

3
More training

needed

5 
9. The following questions relate to your current attitudes regarding computers and the use of computers for teaching and learning. Circle the number that best reflects how you feel.

\begin{tabular}{|c|c|c|c|c|}
\hline $\begin{array}{l}\text { Strongly } \\
\text { Disagree }\end{array}$ & Disagree & Agree & Strongly Agree & \\
\hline 1 & 2 & 3 & 4 & $\begin{array}{l}\text { I feel self-confident about using } \\
\text { computers for teaching and learning. }\end{array}$ \\
\hline 1 & 2 & 3 & 4 & $\begin{array}{l}\text { I feel that too much emphasis is } \\
\text { being placed on the use of } \\
\text { computers for teaching and learning. }\end{array}$ \\
\hline 1 & 2 & 3 & 4 & $\begin{array}{l}\text { I am concerned about having } \\
\text { enough time to learn about } \\
\text { computers so that I can use them } \\
\text { effectively. }\end{array}$ \\
\hline 1 & 2 & 3 & 4 & $\begin{array}{l}\text { At this time, I am not interested in } \\
\text { learning about computers. }\end{array}$ \\
\hline 1 & 2 & 3 & 4 & $\begin{array}{l}\text { Learning to use computers will } \\
\text { make me a more effective teacher. }\end{array}$ \\
\hline 1 & 2 & 3 & 4 & $\begin{array}{l}\text { Computer literacy should be a } \\
\text { learning outcome of our school } \\
\text { system. }\end{array}$ \\
\hline 1 & 2 & 3 & 4 & $\begin{array}{l}\text { I am overwhelmed about having to } \\
\text { learn and use computers for teaching } \\
\text { and learning. }\end{array}$ \\
\hline 1 & 2 & 3 & 4 & $\begin{array}{l}\text { Computer use should be limited to a } \\
\text { computer lab instead of being } \\
\text { integrated into the classroom } \\
\text { curriculum. }\end{array}$ \\
\hline 1 & 2 & 3 & 4 & $\begin{array}{l}\text { All classrooms should be equipped } \\
\text { with computers. }\end{array}$ \\
\hline 1 & 2 & 3 & 4 & $\begin{array}{l}\text { All students should use the Internet } \\
\text { as part of the curriculum for } \\
\text { instruction, learning and research. }\end{array}$ \\
\hline 1 & 2 & 3 & 4 & $\begin{array}{l}\text { All teachers should use the Internet } \\
\text { for communication, instruction } \\
\text { development, and research. }\end{array}$ \\
\hline 1 & 2 & 3 & 4 & $\begin{array}{l}\text { I am concerned about what my } \\
\text { employer(s) might expect me to } \\
\text { know about computers and how } \\
\text { those expectations might be in } \\
\text { conflict with what I want to do. }\end{array}$ \\
\hline 1 & 2 & 3 & 4 & $\begin{array}{l}\text { Computer technology and the } \\
\text { Internet have limited application in } \\
\text { the subject I teach. }\end{array}$ \\
\hline
\end{tabular}


10. To what extent do you use the Internet/computers for your job in the following areas? Check the most appropriate response for each item:

\begin{tabular}{|c|c|c|c|c|c|}
\hline $\begin{array}{l}\text { Use of the } \\
\text { Internet/Computer for: }\end{array}$ & Extensively & Often & Sometimes & $\begin{array}{l}\text { Not very } \\
\text { often }\end{array}$ & Never \\
\hline $\begin{array}{l}\text { Curriculum/lesson plan } \\
\text { development }\end{array}$ & 1 & 2 & 3 & 4 & 5 \\
\hline In-class instruction & 1 & 2 & 3 & 4 & 5 \\
\hline $\begin{array}{l}\text { Student research } \\
\text { assignments }\end{array}$ & 1 & 2 & 3 & 4 & 5 \\
\hline $\begin{array}{l}\text { Instructional video } \\
\text { conferencing }\end{array}$ & 1 & 2 & 3 & 4 & 5 \\
\hline $\begin{array}{l}\text { Online collaboration } \\
\text { learning with other schools }\end{array}$ & 1 & 2 & 3 & 4 & 5 \\
\hline Virtual fieldtrips & 1 & 2 & 3 & 4 & 5 \\
\hline $\begin{array}{l}\text { Educational closed circuit } \\
\text { TV programs }\end{array}$ & 1 & 2 & 3 & 4 & 5 \\
\hline E-mailing parents & 1 & 2 & 3 & 4 & 5 \\
\hline E-mailing students & 1 & 2 & 3 & 4 & 5 \\
\hline $\begin{array}{l}\text { Online grade databases } \\
\text { (edline) }\end{array}$ & 1 & 2 & 3 & 4 & 5 \\
\hline Instant Messaging & 1 & 2 & 3 & 4 & 5 \\
\hline Educational blogs & 1 & 2 & 3 & 4 & 5 \\
\hline Listservs & 1 & 2 & 3 & 4 & 5 \\
\hline
\end{tabular}

11. To what extent do you use the following additional types of technology for your job. (Check the most appropriate response for each item.

Use of: $\quad$ Extensively Often Sometimes Not very Never often

\begin{tabular}{|c|c|c|c|c|}
\hline Fax machine & 1 & 2 & & 3 \\
\hline Electronic whiteboards & 1 & 2 & & 3 \\
\hline Digital camera & 1 & 2 & & 3 \\
\hline PDA & 1 & 2 & & 3 \\
\hline LCD panel & 1 & 2 & & 3 \\
\hline
\end{tabular}


12. Briefly describe the impact that computers have had on your work as a teacher.

13. Which computer technologies have had the most impact in your classroom?

14. Briefly describe your level of comfort/anxiety in using computers as an instructional tool.

15. Do you feel that you are adequately prepared/trained to make effective use of computer technology in your classroom? Briefly explain.

16. Is there any area of technology about which you would like more training?

17. What additional measures could be taken to enable you to make more effective use of computer technology? (This might include additional training, computer hardware or software enhancements, etc.) 
18. Please list any additional comments below:

The following questions are about you:

Age:

Under 30
30-45
Over 45

Number of years teaching

5 and under
$6-10$


$11-20$
over 20

Number of years at this school

Area of Specialization:

English/Language Arts

Math

Social Studies

Science

Related Arts/Allied Arts

Special Education

Thank you for your time in completing this survey!

*Please return to the box in the office by the mailboxes when completed* 


\section{Appendix C \\ Technology Integration}

\section{Interview Questions}

1. In your opinion, what impact has technology integration had on the school over past 10 years?

2. What computer technologies do you feel have had the most impact in the school?

3. Discuss the technology training the faculty has received. Has it been helpful and meaningful in the integration of computer into your curriculum?

4. Briefly describe your comfort/anxiety level in using computer technology as an instructional tool.

5. What measures could be taken to make computer technology more effective in the future? Where do you see computer technology going in the future?

6. Is there anything else you would like to discuss in regard to technology in the schools? 


\section{Appendix D}

\section{Infrastructure Inventory of ABC Middle School \\ October 1996}

\section{Communication Technology Infrastructure Analysis}

Location: ABC Middle School - Computer Lab

Contact Person at this Location: Dr. K.M.

\section{Level 1: External}

Satellite - several - accesses Channel 1 TV through satellite

Radio/TV antenna - none found

Cable $T V$ - most basic channels, including PBS

Telephone Lines - Ethernet connection (T1) - drop sites developed but because of some mix up (given token ring router instead of Ethernet router) the connection is not connected yet. Now they are waiting to get connected as soon as the ComputerLand of Charleston comes to set them up.

\section{Level II: Internal}

Voice: Intercom - In all classrooms

PA system - In office - also closed circuit TV available.

Data (computer) - In office

Data (other) - Thermostat

Safety Systems-

Back up Lights - yes

Sprinkler - yes 
Smoke Detector - yes

Security System - unsure

Network Connections - The computer lab is an I Class system of management with an Ethernet connection. The network system is running off a server, which is housed in a room adjoining the computer lab. In the library there is a second server which can also be connected to the computer lab server. All of the wiring is externally wired underneath the computer tables and along the walls.

Telephone -

Lines (for computer connection) currently they have category 3 twisted pair, according to their technology plan they will be upgrading to a Fiber Optic Backbone Five (Plenum) copper.

Handsets- Several located throughout the school - none in the computer lab. Speakerphone - Several throughout the school, office.

TV Monitor - One in every classroom

\section{Computers}

Processor Speed - upgraded IBM computers

Hard Drive - $8 \mathrm{MG}$

Disk drives - Internal

$R A M$ - varies with computer

Audio Cards - unable to locate

Video Cards - unable to locate

$C D R O M$ - three computers had CD ROM - server in lab and 2 in library Monitor - all computers had one 
Modem - none - Ethernet connection, not needed

Microphone - unable to locate

Network type - runs off server/I Class

Servers - two, one in lab, one in library

Multimedia Equipment - Laser disk players, camcorders, VCR's

Facsimile - in office

Printer - In lab there were 4 printers - 3 dot matrix and one HP Desk jet printer, there are others located throughout the school.

Plotter - unable to locate

Bells and Clocks - Clocks are electric, hand set clocks. Bell system located in office.

Software - word processing, some programming, problem solving (LOGO) not much on basic skills.

\section{Information}

\section{Summary}

I have chosen ABC Middle School for the site based study. I chose a school based site because of the researcher's previous teaching experience and current focus on a masters in Instructional Technology.

During my brief visit to the school, I found that they had around 30 IBM computers in a lab setting. I have also seen some Macintosh computers in other locations. I was told that the children rotate courses every $4 \frac{1 / 2}{2}$ weeks, and one of these mini courses is Computer Lab. During the time the children attend lab class, they will have it every day for around 45 minutes. In the lab they do keyboarding and other computer literacy activities as well as basic programming commands. 
ABC Middle School computer lab is being used to teach the graded subject area of Computer Literacy. This is a unique program in ABC County, since most computer labs function as basic skills labs.

All students in grades 5-8 attend computer classes daily for a four week period and then rotate to other special topic classes. At this point, all grades are taught basic computer literacy skills, since this program is so new and the students have not been exposed to computer literacy. As the children who are now in $5^{\text {th }}$ and $6^{\text {th }}$ grades move up, they will already have the basic understanding of this course and be moved on to some more complex problem solving and programming skills.

Computer concepts being taught in this lab include the history of the computer, understanding the different types of computers, how the computer works, programming terminology, basic programming skills, and other practical, logical uses of the computer. One big idea that the technology teacher wants to stress is that the computer is not a toy but instead a learning tool. The students are not to "play" on the computer, but instead use it to help them learn. Software used for this course includes the word processor, some programming tutorials, and other related computer literacy programs.

As the second basic skills lab opens in the near future, this lab will be used as a supplementary medium of teaching the other subject areas. The lab will have software based on the subject areas. Also, when the Ethernet connection gets hooked up, students will have Internet access with a "firewall" implemented by the county to prevent access to inappropriate sites.

The libraries computers are being used as more of a tool in researching, word processing, and database research. 


\section{Teaching and Learning}

At this time the main computer lab is being utilized as a teaching site. The children are taught lessons on computer literacy. Of course, as with any good teaching lesson, the children are also allowed to do some exploration and hands on learning, so it does become a learning center too.

The basic skills lab will also be used as a teaching center, I predict, except when teachers have students do research on the Internet. The library computers are most definitely being primarily used as a learning center, where students come to access information without formal instruction from the media specialist.

\section{Messaging}

There is no formal e-mail messaging system set up at this time. It has the capability to develop a LAN messaging network since the servers are networked together, but there is no real need for this at this time. I suspect that when the Internet connections get hooked up, the possibility of giving the students and staff access to email through the Internet would be a possibility. 


\section{Appendix E \\ Infrastructure Inventory 2007}

Infrastructure Inventory of ABC Middle School

\section{Communication Technology Infrastructure Analysis}

Location: ABC Middle School

Contact Person at this Location: Technology Contact Teacher

\section{Level 1: External}

Satellite - Several, one located in library to access channel 1 television, one in

Technology Education classroom.

Radio/TV antenna - None found

Cable TV-Basic channels, including PBS.

Telephone Lines- Several phone lines/fax lines to school. Internet connection is also run through 2 T-1 lines through Verizon. Lines are connected to wireless connection drop points throughout the school.

\section{Level II: Internal}

Voice: Intercom - In all classrooms

PA system - In office - also closed circuit TV available.

Data (computer) - In office with WVEIS also online accessible gradebooks

(Edline ${ }^{\mathrm{TM}} /$ Gradequick) and E-mail through access.

Data (other) - Thermostat

Safety Systems-

Back up Lights - Yes

Sprinkler - Yes

Smoke Detector - Yes - automatically connected to the fire department. 
Security System - Yes

-Cameras in hallways and outside doors with video recordings from the cameras.

- All outside doors locked with buzzer/electronic keycard entry at two sites.

- Closed circuit TVs with intercom to office at front door to monitor visitors. Network Connections -

The network is run off a server which runs the middle and elementary schools. All students and staff are given a login and password. Cat 5 wires are wired throughout the school to connect to the server/Internet. All computers are on "deep freeze" which freezes the computer in the previous state after log off to prevent unwanted changes to the system. The school has 267 drop sites in the school to gain Internet/server connection.

Telephone Lines- The school has CAT 5 connections.

Handsets- The principal and assistant principal each have a PDA.

Speakerphone - Several throughout the school, office.

TV Monitor - One in every classroom

\section{Computers}

There are 240 computers in the school use in the school. There are 2 labs with 30 computers in each lab and the library houses 15 computers. The rest of the computers are spread throughout the classrooms.

Processor Speed - A majority of the computers are Windows XP computers with a small percentage still running Windows 98 . The school has a goal to replace all of the 98 computers within the next few years. 
Hard Drive $-2 \mathrm{GHz}$ to $3 \mathrm{GHz}$ depending upon the age of the computer. Most of the software and data storage are held on the server for the school.

Disk drives - Some have internal disk drives, most have internal CD and or DVD drives. Several have DVR capabilities. The school also uses the travel disk/USB flash drives to save data. Each teacher received a travel disk for their classroom.

$R A M$ - varies with computer Audio Cards - Many of the newer computers had these.

Video Cards - Many of the newer computers had these.

$C D R O M$ - A majority of the computers had a CD drive. Several with DVR Monitor - All computers had one.

Modem - none - Ethernet connection, not needed Microphone - Newer computers had built-in microphone Network type - Runs off server (Local Area Network/LAN) Servers - Share server with Elementary school. Has a back up battery for server. Multimedia Equipment - Digital camera, digital camcorder, electronic whiteboard, LCD projector, scanner.

Facsimile - in office

Printer- Many printers throughout school - including network laser printers for each grade level. Printers range from inkjet to laser in a wide range of levels.

Plotter - unable to locate Bells and Clocks - Clocks are electric, hand set clocks. Bell system located in office, runs off computer program. 
Software - Office Suite. (Word 2003 ${ }^{\mathrm{TM}}$, Powerpoint ${ }^{\mathrm{TM}}$, Excel, ${ }^{\mathrm{TM}}$ Access ${ }^{\mathrm{TM}}$, Microsoft Publisher $^{\mathrm{TM}}$, Movie Maker ${ }^{\mathrm{TM}}$ ), Online programs (Ebscohost ${ }^{\mathrm{TM}}$, Edhelper $^{\mathrm{TM}}$, Edline $^{\mathrm{TM}} /$ Gradequick, United Streaming $^{\mathrm{TM}}$, Teacher Tube ${ }^{\mathrm{TM}}$, Bridges $\left.{ }^{\mathrm{TM}}\right) ; \mathrm{Plato}^{\mathrm{TM}}, \mathrm{AB}$ Tutor $^{\mathrm{TM}}$, Reading Counts ${ }^{\mathrm{TM}}$ and PhotoShop ${ }^{\mathrm{TM}}$.

\section{Information}

\section{Summary}

This infrastructure was done on the same school after a 10-year time span. The infrastructure data were gathered from discussions with the Technology Contact teacher and principal. Additional data were gathered from the school's Digital Divide report, the school inventory, and physical observations made at the school in April 2007.

The school has increased the number of computers it has throughout the school. All of the computers and many of the printers are connected to a network. There are 2 computer labs, with 30 computers in each. The labs also have a LCD projector and one of the labs also has a Numonics electronic whiteboard. The library has 15 computers which can also be accessed by teachers with their classes as well as students doing research or searching for books in the library. The Technology Education lab also has ten computers which are used for broadcasting, web development, bridge building and other technology programs.

Several computer class electives are taught in the labs on a regular basis. This includes a "Basic Computers" class, teaching basic computer elements, software, cybersafety, and Internet research skills. Students in 7th and 8th grade can sign up for this class as an elective. There is also a 6-week rotation course for Intro to Computers, where 
students in 6th, 7th, and 8th rotate through this class. This gives a brief overview of many of the basic computer software programs.

The lab is also used for an art class on Adobe Photoshop, where students learn to manipulate digital pictures. The yearbook elective is also held in the lab. Classroom teachers can sign up for lab time to bring their students into the lab for a specific lesson. Teachers are encouraged to use the lab to help enrich their curriculum. Many teachers use the lab for Plato ${ }^{\mathrm{TM}}$, United Streaming ${ }^{\mathrm{TM}}$, Processing, Powerpoint ${ }^{\mathrm{TM}}$, making brochures, taking Reading Counts ${ }^{\mathrm{TM}}$ quizzes, looking up books on the card catalog, online research, webquests, and online testing.

The computer network has some safe guards to help block inappropriate material. The school district has a filtering system that blocks many of the inappropriate sites. Several sites are banned due to the tendency towards inappropriate materials (such as You Tube). There is also the Deep Freeze, which freezes the computers in the state in which they are, which prevents any changes the students may make to the computers to be converted back at the next login. The labs are also equipped with AB Tutor, which allows the teacher's station to watch and if necessary lock the computer of any student not working on the correct assignment. All students and staff are required to sign an Acceptable Use Policy for the computer before using the equipment. This explains the rules to allow the privilege of using the equipment.

\section{Teaching and Learning}

The West Virginia Department of Education (WVDE) has included Technology goals in their objectives and standards. There are specific technology goals for Kindergarten through 8 th grade. The goals are broken up into several categories, with 
each category getting more advanced as the student moves through the grades. The categories include: Basic (to Advanced) Operations and Concepts, Social Ethical and Human Issues, Technology Productivity Tools, Technology Communication Tools, Technology Research Tools, and Technology Problem Solving and Decision Making Tools (WVDE website, Technology Standards and Objectives, retrieved September 1, 2007 at http://boe.mono.k12.wv.us/Resources/techskills.htm). This school covers these objectives in two ways: through the computer classes and incorporation into the other core curriculum classes.

The computer usage have moved away from the Basic Skills setting where students do more drill and practice type activities and towards using the computers as a learning tool to gain and organize information. While there still are some educational games online, most of the activities involve the students researching, creating, writing, publishing and editing. The textbooks series offers online activities for the students to further explore the units. Many of the textbooks even offer online versions of the text with access codes for the students to use the book at home without having to carry heavy books back and forth. The online texts also offer additional problems, quizzes, step-bystep help and enrichment/remediation activities.

Students save their work on their student folders on the server. Teachers can also access their assignments through the student folders or they can put assignments into the student's folder. Since these folders are available on the server, the students can have access to their assignment in any of the labs or in their classroom.

A new technology that was not even available during the last study is the interactive electronic whiteboard. The whiteboard is mounted on the wall with an LCD 
projector hooked up to a computer/labtop to project what is on the screen. Beyond just projecting the image it also allows the teachers or students to move objects, click on places on the screen (like icons) and opens the program just like clicking a mouse would. There is a pen feature so teachers or students can highlight or fill in answers to questions right on the screen. The school received the first order of the whiteboards this year. One teacher in each grade level received a laptop, whiteboard, and projector. There is also a whiteboard in one of the computer labs where all teachers can sign up to use. Training has just begun on the whiteboards but many teachers show enthusiasm about learning to utilize them in their classrooms.

Teacher training is another aspect of the teaching and learning in the schools. Each school has a technology contact teacher who provides support and training for the teachers and students at the school. The technology contact teachers work with the technology director to help facilitate the technology adoption and training. There are training workshops offered as part of staff development during the school year and also during summer mini-courses. There is also online training materials for teachers to use as references. Due to time constraints in the schedules there is not a lot of time available to train the teachers to use the new technology and it often takes a while for a new technology to be in full use. Mandated programs such as Edline ${ }^{\mathrm{TM}}$ and Gradequick have more training available at this time.

\section{Messaging}

There has been a surge in messaging options for the teachers, parents, students and administrators to communicate. Each faculty member has an e-mail address that is 
published on the school's website. The e-mail is web-based, so the teachers can check their e-mail at home or at school.

Another important communication tool is Edline $/{ }^{\mathrm{TM}}$ Gradequick

(www.edline.com). Edline $\mathrm{TM}^{\mathrm{TM}}$ is a web-based communication program which specifically links to the students account. Each parent and each student receives a password-based account. A calendar of events, school calendar, and any other important information is posted on the Edline ${ }^{\mathrm{TM}}$ site to help keep parents and students informed. Each teacher also has an Edline ${ }^{\mathrm{TM}}$ page for each of their classes where they can post specific assignments, notes, or messages. Gradequick is connected to Edline $\mathrm{TM}^{\mathrm{TM}}$ and is an online gradebook. Teachers enter the students grades and assignments weekly (or even more often). The Gradequick program keeps a running average for the students' grades, based on weighting and other factors. Missing work, incomplete work, late work and attendance are also noted on the report. The parents can choose to have an e-mail sent to them whenever grades are updated in Edline ${ }^{\mathrm{TM}}$. This allows parents and teachers to communicate and make sure the student is doing his or her work. Edline ${ }^{\mathrm{TM}}$ also offers an "e-mail user" feature, where the teacher can e-mail all of the parents and or students with important announcements.

Each school in the county also has a website which contains information about the school, events, and contact information. ABC Middle School also has a PTO website where parents can read about ways to become involved in the Parent Teacher Organization and learn about the latest fund raisers and volunteer opportunities. The county and state also maintain a website which lists everything from parent resources, calendars, menus, policies and many other resources for the parents. 
Another form of messaging available to the families is the School Closing and Announcements website which is run by the State Board of Education. This is a valuable tool for parents to find out if school is closed, delayed, or dismissed early due to bad weather. Parents can access the site themselves or can be e-mailed with an announcement about the counties for which they request information.

The school is also going to introduce anther phone system called Parent Link beginning next year. This program will allow the school system to contact parents via a phone call when there is a school emergency, cancellation or other important announcement. A mass message will be sent to all of the parents using this automated system, allowing them to keep informed and not jamming the schools phone lines with questions or concerns.

Another source of data is the WV Digital Divide Survey for the last 2006-07 school year. These reports are explained on the WVDE website:

"Digital Divide Survey information is self-reported technology survey data collected from WV K-12 schools. This information evolves from the West Virginia K-12 strategic technology planning process for improved student achievement; the reported data enables West Virginia Department of Education, counties and schools to meet reporting requirements mandated by the federal programs, E-rate and No Child Left Behind, Title II, Part D.” (Retrieved January 25, 2007 at http://wvde.state.wv.us/data/digitaldivide/2006.html.) (see Table 51). 
Table 51

2006 Digital Divide Report for the ABC Middle School

WVEIS XYZ County - ABC MIDDLE SCHOOL

STUDENT COMPUTERS

\begin{tabular}{|c|c|c|c|c|c|c|c|}
\hline & \multicolumn{2}{|c|}{ Windows Windows } & $\begin{array}{r}\text { Windows } \\
98\end{array}$ & $\begin{array}{r}\text { Windows } \\
\text { NT/2000 }\end{array}$ & \multicolumn{2}{|c|}{$\begin{array}{r}\text { Windows } \\
\text { XPacintosh } \\
\text { (All } \\
\text { Versions) }\end{array}$} & Total \\
\hline Count & 0 & 0 & 59 & 0 & 163 & 0 & 222 \\
\hline Percentage & 0.0 & 0.0 & 26.6 & 0.0 & 73.4 & 0.0 & \\
\hline
\end{tabular}

\section{Counts of STUDENT Computers (Desktops and Notebooks) Windows} 98 and Higher / Windows XP

\begin{tabular}{|c|c|c|c|c|}
\hline $\begin{array}{c}\text { Total Total } \\
\text { Students Teachers }\end{array}$ & $\begin{array}{r}\text { Total } \\
\text { Computers } \\
\text { Windows } \\
98 \\
\text { or Higher }\end{array}$ & $\begin{array}{r}\begin{array}{r}\text { Student } \\
\text { to }\end{array} \\
\text { Computer } \\
\text { Ratio Win } \\
98 \\
\text { or Higher }\end{array}$ & $\begin{array}{r}\text { Total } \\
\text { Computers } \\
\text { Windows } \\
\text { XP } \\
\text { or Higher }\end{array}$ & $\begin{array}{r}\text { Student to } \\
\text { Computer } \\
\text { Ratio Win } \\
\text { XP } \\
\text { or Higher }\end{array}$ \\
\hline 577 & 222 & 2.60 & 163 & 3.54 \\
\hline
\end{tabular}

Administrative, NonInstructional, and Student Computers

\begin{tabular}{|c|c|c|c|c|c|c|c|}
\hline & \multicolumn{2}{|c|}{ Windows Windows } & \multirow{2}{*}{$\begin{array}{r}\text { Windows } \\
98\end{array}$} & \multirow{2}{*}{$\begin{array}{r}\text { Windows } \\
\text { NT/2000 }\end{array}$} & \multirow{2}{*}{$\begin{array}{r}\text { Windows } \\
\text { XP }\end{array}$} & \multirow{2}{*}{$\begin{array}{r}\text { Macintosh } \\
\text { (All } \\
\text { Versions) }\end{array}$} & \multirow{2}{*}{ Total } \\
\hline & 3.1 & 95 & & & & & \\
\hline Count & 0 & 0 & 62 & 0 & 170 & 0 & 232 \\
\hline Percentage & 0.0 & 0.0 & 26.7 & 0.0 & 73.3 & 0.0 & \\
\hline
\end{tabular}

\begin{tabular}{rr} 
Internet Access \\
$\begin{array}{c}\text { Computers and } \\
\text { Laptops with Internet } \\
\text { Access }\end{array}$ & Number of Drops \\
232 & 267 \\
\hline
\end{tabular}

Technology Integration Hours of Training School Year 2005/2006

\begin{tabular}{|c|c|c|c|c|c|c|c|}
\hline & $\begin{array}{c}\text { Number } \\
\text { of } \\
\text { Teachers }\end{array}$ & $\begin{array}{r}\text { Teachers } \\
\text { Trained } 0 \\
\text { Hours }\end{array}$ & $\begin{array}{r}\text { Teachers } \\
\text { Trained } \\
1-5 \text { Hours }\end{array}$ & $\begin{array}{r}\text { Teachers } \\
\text { Trained } \\
6-15 \\
\text { Hours }\end{array}$ & $\begin{array}{r}\text { Teachers } \\
\text { Trained } \\
16-25 \\
\text { Hours }\end{array}$ & $\begin{array}{r}\text { Teachers } \\
\text { Trained } \\
26-50 \\
\text { Hours }\end{array}$ & $\begin{array}{r}\text { Teachers } \\
\text { Trained } \\
\text { More } \\
\text { than } 50 \\
\text { Hours }\end{array}$ \\
\hline Count & 45 & 0 & 20 & 18 & 4 & 3 & 0 \\
\hline Percentage & & 0.0 & 44.4 & 40.0 & 8.9 & 6.7 & 0.0 \\
\hline
\end{tabular}

Home / School Communication

$\begin{array}{rrr}\text { Voice } & \begin{array}{r}\text { Voice } \\ \text { Mail Wehool }\end{array} & \text { Email } \\ \text { Broadcast } & & \checkmark\end{array}$


Technology Integration 222

Table 51 continued...

\section{Distance Learning}

\begin{tabular}{|c|c|c|}
\hline $\begin{array}{r}\text { Courses } \\
\text { Delivered } \\
\text { by } \\
\text { Technology }\end{array}$ & $\begin{array}{l}\text { Online } \\
\text { Courses } \\
\text { through Conferencing } \\
\text { the WV Technologies } \\
\text { Virtual } \\
\text { School }\end{array}$ & $\begin{array}{r}\text { Courses } \\
\text { Delivered } \\
\text { through } \\
\text { Video- } \\
\text { Conferencing } \\
\text { Technologies }\end{array}$ \\
\hline
\end{tabular}

